Prepared in cooperation with the Oklahoma Water Resources Board

\title{
Hydrogeology and Simulated Groundwater Flow and Availability in the North Fork Red River Aquifer, Southwest Oklahoma, 1980-2013
}

Scientific Investigations Report 2017-5098 
Front cover, Boat ramp at Lake Altus, Okla., during hydrologic drought conditions, December 20, 2012. Photo by Kevin A. Smith, used with permission.

Back cover, Lake Altus Dam near Lugert, Okla., January 4, 2003. Photo by S. Jerrod Smith. 


\section{Hydrogeology and Simulated Groundwater Flow and Availability in the North Fork Red River Aquifer, Southwest Oklahoma, 1980-2013}

By S. Jerrod Smith, John H. Ellis, Derrick L. Wagner, and Steven M. Peterson

Prepared in cooperation with the Oklahoma Water Resources Board

Scientific Investigations Report 2017-5098 


\title{
U.S. Department of the Interior \\ RYAN K. ZINKE, Secretary
}

\section{U.S. Geological Survey William H. Werkheiser, Acting Director}

\author{
U.S. Geological Survey, Reston, Virginia: 2017
}

For more information on the USGS - the Federal source for science about the Earth, its natural and living resources, natural hazards, and the environment-visit https://www.usgs.gov or call 1-888-ASK-USGS.

For an overview of USGS information products, including maps, imagery, and publications,

visit https://store.usgs.gov.

Any use of trade, firm, or product names is for descriptive purposes only and does not imply endorsement by the U.S. Government.

Although this information product, for the most part, is in the public domain, it also may contain copyrighted materials as noted in the text. Permission to reproduce copyrighted items must be secured from the copyright owner.

Suggested citation:

Smith, S.J., Ellis, J.H., Wagner, D.L., and Peterson, S.M., 2017, Hydrogeology and simulated groundwater flow and availability in the North Fork Red River aquifer, southwest Oklahoma, 1980-2013: U.S. Geological Survey Scientific Investigations Report 2017-5098, 107 p., https://doi.org/10.3133/sir20175098.

ISSN 2328-031X (print)

ISSN 2328-0328 (online) 


\section{Acknowledgments}

The project documented in this report was conducted as part of the U.S. Geological Survey (USGS) Cooperative Water Program in cooperation with the Oklahoma Water Resources Board (OWRB). The authors value the contributions of many OWRB and USGS staff that led to the successful completion of the project. The authors thank the OWRB for support on this project and OWRB Water Resources geologist Christopher Neel for help with defining study objectives and providing hydrogeologic data. OWRB geologist Jon Sanford compiled drawdown data from well completion reports.

The authors also thank former USGS employees Noel Osborn, who provided initial project coordination and management, and Trevor Grout, who compiled, organized, and analyzed available hydrologic and spatial data. USGS employees Marty Phillips and Martin Schneider measured stream base flow, and Kevin Smith measured hydraulic conductivity and water-table altitudes in addition to siting and maintaining continuous water-level recorder wells. Shana Mashburn provided guidance on recharge estimation techniques and facilitated data entry to the National Water Information System database. The authors acknowledge and appreciate the professionalism, experience, and dedication of these helpful colleagues. 



\section{Contents}

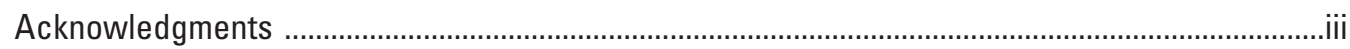

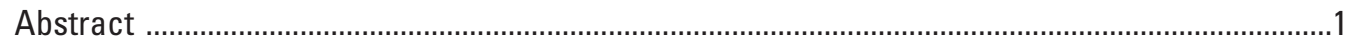

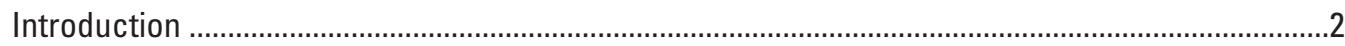

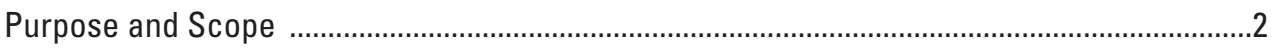

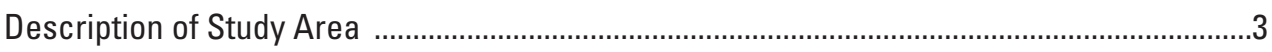

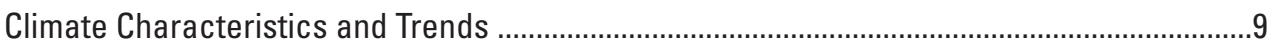

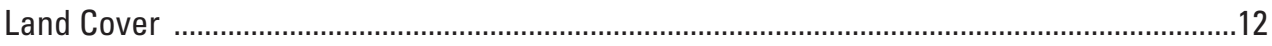

Groundwater-Use Characteristics and Trends ............................................................12

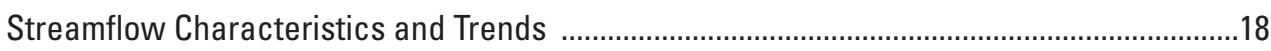

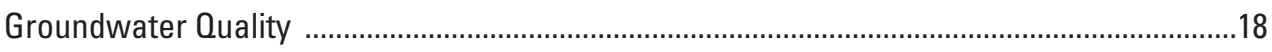

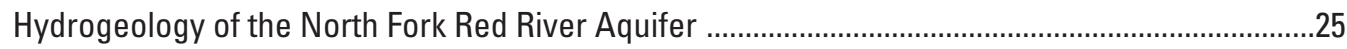

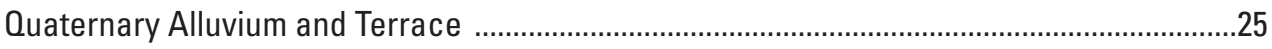

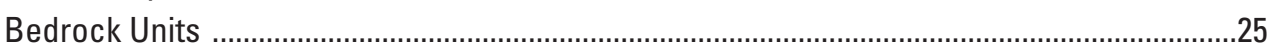

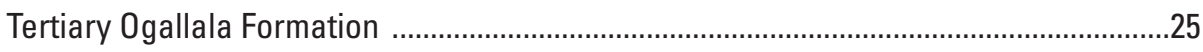

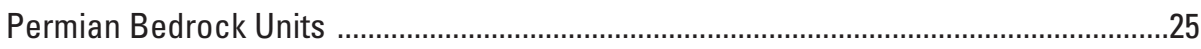

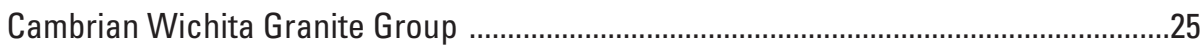

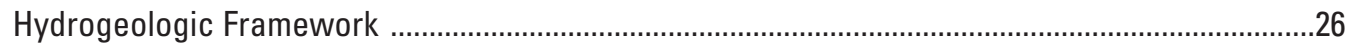

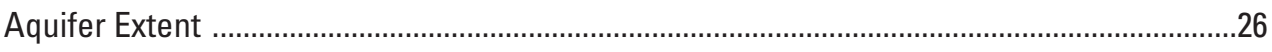

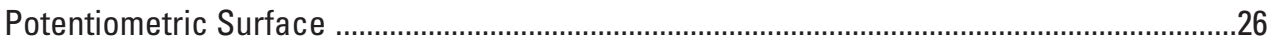

Textural and Hydraulic Properties of Aquifer Material .........................................................27

Lithologic Log Standardization and Calculation of Percentage-Coarse-Material

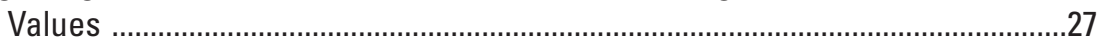

Spatial Distribution of Percentage-Coarse-Material Values ............................................27

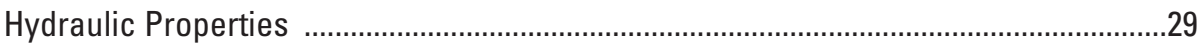

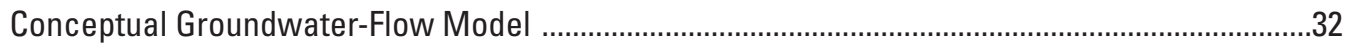

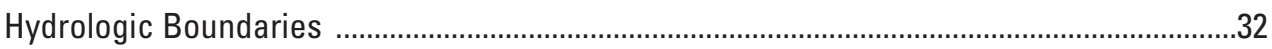

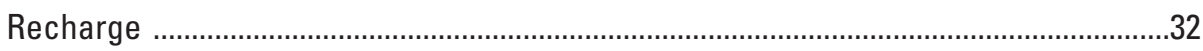

Lateral Groundwater Flows ..................................................................................

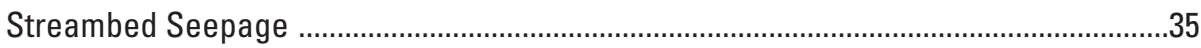

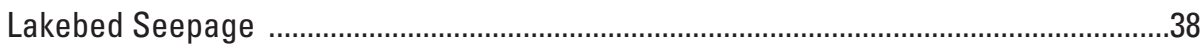

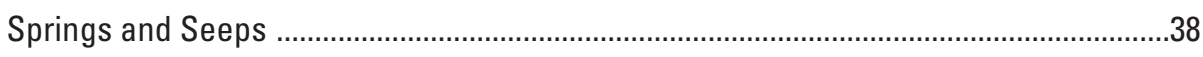

Saturated-Zone Evapotranspiration .......................................................................38

Well Withdrawals, Water-Level Response, and Storage Change .................................39

Conceptual Groundwater-Flow Model Water Budget ...........................................................39

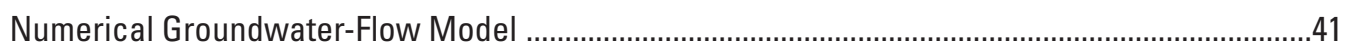

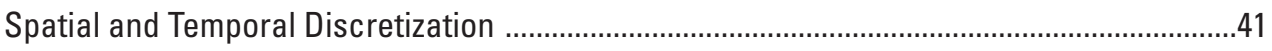

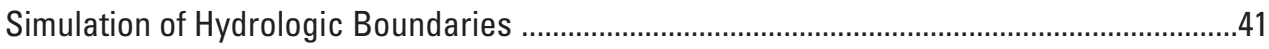

Recharge and the Soil-Water-Balance Code ..............................................................41

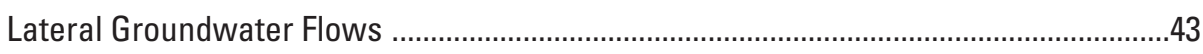

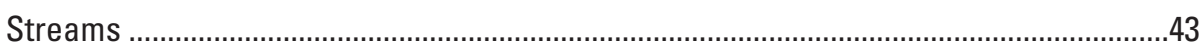

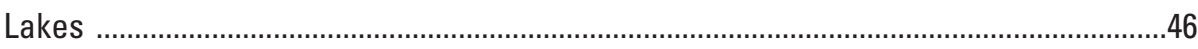

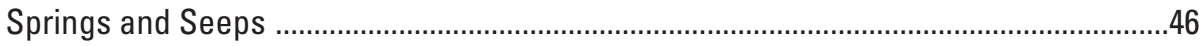

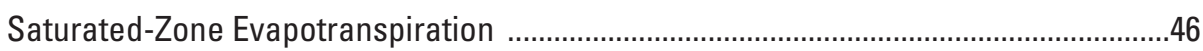




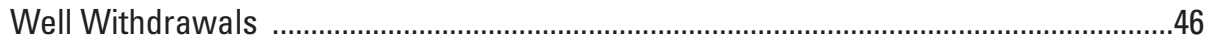

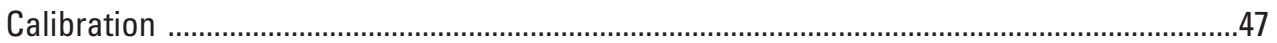

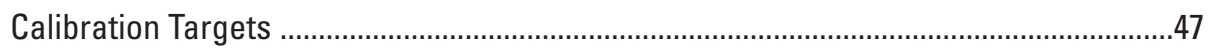

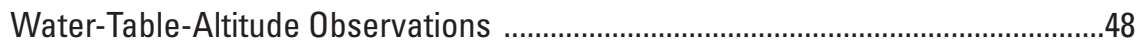

Base Flow and Net Streambed Seepage ...............................................................48

Lake Altus Stage ..............................................................................................49

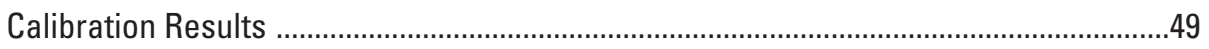

Simulated Aquifer Thickness and Saturated Thickness ..........................................49

Comparison of Simulated and Observed Values .......................................................50

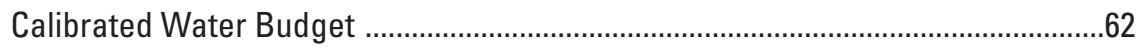

Calibrated Parameter Values and Sensitivities ....................................................64

Differences in Numerical Groundwater-Flow Models ......................................................69

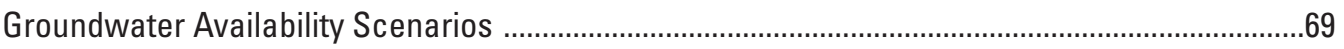

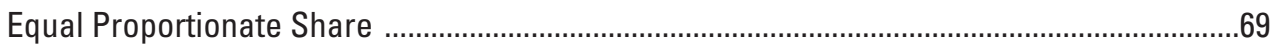

Projected (50-Year) Pumping .........................................................................................

Hypothetical (10-Year) Drought ....................................................................................

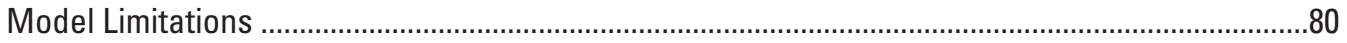

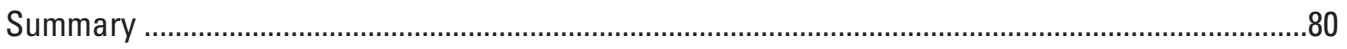

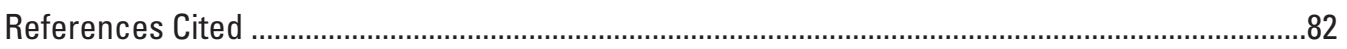

\section{Figures}

1. Map showing the North Fork Red River aquifer study area, southwest Oklahoma .........4

2. Map showing major geographic and surface-water features in and near the North Fork Red River watershed, southwest Oklahoma and northwest Texas .................5

3. Graphs showing annual mean precipitation; annual mean temperature; and depth to water in selected wells, southwest Oklahoma, 1895-2015 ..............................10

4. Graphs showing mean monthly precipitation and mean monthly temperature, southwest Oklahoma, 1895-2015 and 1980-2013

5. Map and pie charts showing land and crop cover over the North Fork Red River aquifer, southwest Oklahoma, 2010-15

6. Map showing land areas and wells permitted for groundwater use from the North Fork Red River aquifer, southwest Oklahoma, 2015

7. Graph showing annual reported groundwater use by type from the North Fork Red River aquifer, 1967-2013

8. Graph showing annual reported groundwater use by county from the North Fork Red River aquifer, 1980-2013

9. Boxplot showing statistics for reported yields of wells completed in the North Fork Red River aquifer ..

10. Map showing groundwater-quality stations in the North Fork Red River aquifer, southwest Oklahoma, 1944-62 and July-August 2014

11. Stratigraphic chart showing surficial geologic and hydrogeologic units of the North Fork Red River aquifer study area, southwest Oklahoma

12. Map showing surficial geologic units and major structural features of the North Fork Red River aquifer study area, southwest Oklahoma

13. Piper diagram showing groundwater-quality samples of water produced from the North Fork Red River aquifer, 1944-62 and July-August 2014 
14. Map showing potentiometric surface contours and general direction of groundwater flow in the North Fork Red River aquifer, 2013

15. Graph and boxplot showing distributions of estimated hydraulic conductivity observations in the North Fork Red River aquifer

16. Graph showing mean annual flow by water-budget category for the conceptual model and the calibrated numerical model of the North Fork Red River aquifer, 1980-2013

17. Graph showing daily precipitation and depth to water in continuous water-level recorder wells completed in the North Fork Red River aquifer, February 2013 through January 2015

18. Map showing base-flow measurements with gaining and losing reaches of the North Fork Red River and tributaries, March 2013

19. Graphs showing monthly streamflow, monthly base flow, and annual base-flow index for Sweetwater streamgage (07301420) on Sweetwater Creek; Carter streamgage (07301500) on North Fork Red River; and Headrick streamgage (07305000) on North Fork Red River, 1980-2013

20. Graphs showing annual water-level measurements and mean annual waterlevel change by county for Oklahoma Water Resources Board Mass Measurement Program wells completed in the North Fork Red River aquifer, 1978-2014

21. Map showing active area, boundary conditions, and parameter zones for the numerical groundwater-flow model of the North Fork Red River aquifer, southwest Oklahoma

22. Graph showing annual precipitation and annual groundwater recharge computed by using the Soil-Water-Balance code for the North Fork Red River aquifer, 1980-2013.

23. Map showing mean annual groundwater recharge computed by using the SoilWater-Balance code for the North Fork Red River aquifer, 1980-2013

24. Graph showing monthly water demand by groundwater-use type from the North Fork Red River aquifer, 1980-2013

25. Graphs showing temporal distribution of water-table-altitude observations and streamflow observations for the numerical groundwater-flow model of the North Fork Red River aquifer, 1980-2015

26. Graphs showing observed and simulated water-table altitudes and water-tablealtitude residual distributions for the numerical groundwater-flow model of the North Fork Red River aquifer, 1980-2013

27. Map showing spatial distribution of mean water-table-altitude residuals for the numerical groundwater-flow model of the North Fork Red River aquifer, 1980-2013

28. Graphs showing observed and simulated water-table altitudes for the numerical groundwater-flow model of the North Fork Red River aquifer, 1980-2013

29. Graphs showing observed streamflow, observed base flow, and simulated base flow at Sweetwater streamgage (07301420) on Sweetwater Creek; Carter streamgage (07301500) on North Fork Red River; Headrick streamgage (07305000) on North Fork Red River; and Snyder streamgage (07307010) on Otter Creek for the numerical groundwater-flow model of the North Fork Red River aquifer, southwest Oklahoma, 1980-2013

30. Graphs showing Lake Altus stage and simulated storage for the numerical groundwater-flow model of the North Fork Red River aquifer, 1980-2013 
31. Graphs showing annual inflows and outflows and annual change in groundwater storage for the numerical groundwater-flow model of the North Fork Red River aquifer, 1980-2013

32. Graphs showing mean monthly aquifer inflows and outflows and mean monthly change in groundwater storage for the North Fork Red River aquifer, 1980-2013

33. Graphs showing annual lake inflows and outflows and change in lake storage for Lake Altus in the numerical groundwater-flow model of the North Fork Red River aquifer, 1980-2013

34. Graph showing observation group sensitivity by parameter group in the numerical groundwater-flow model for the North Fork Red River aquifer, 1980-2013

35. Graph showing monthly mean precalibration recharge and monthly mean calibrated recharge for the numerical groundwater-flow model of the North Fork Red River aquifer, 1980-2013

36. Map showing horizontal hydraulic conductivity $(\mathrm{Kh})$ for the calibrated numerical groundwater-flow model of the North Fork Red River aquifer, southwest Oklahoma

37. Graph showing percentage of the North Fork Red River aquifer with less than 5 feet of saturated thickness after 20 years of continuous equal-proportionateshare groundwater pumping

38. Map showing simulated saturated thickness and base flow after 20 years of continuous equal-proportionate-share groundwater pumping in the North Fork Red River aquifer, southwest Oklahoma

39. Graphs showing changes in simulated base flow and simulated groundwater storage during 50 years of continuous equal-proportionate-share groundwater pumping in the North Fork Red River aquifer, southwest Oklahoma

40. Graphs showing simulated groundwater storage and simulated mean annual base flow through 50 years of groundwater pumping at selected rates in the North Fork Red River aquifer, southwest Oklahoma

41. Graph showing changes in groundwater storage resulting from a hypothetical 10-year drought (1984-93) for the North Fork Red River aquifer, 1980-97

42. Graphs showing changes in simulated base flow at Sweetwater streamgage (07301420) on Sweetwater Creek; Carter streamgage (07301500) on North Fork Red River; Headrick streamgage (07305000) on North Fork Red River; and Snyder streamgage (07307010) on Otter Creek resulting from a hypothetical 10-year drought (1984-93) for the North Fork Red River aquifer, 1980-97

43. Graphs showing changes in Lake Altus stage and Lake Altus storage resulting from a hypothetical 10-year drought (1984-93) for the North Fork Red River aquifer, 1980-97 


\section{Tables}

1. Selected data-collection stations in and near the North Fork Red River aquifer study area, southwest Oklahoma

2. Mean annual streamflow and mean annual base flow for selected streamgages in and near the North Fork Red River aquifer study area, 1980-2013

3. Mean annual precipitation and mean annual temperature data summaries from selected regions and stations in and near the North Fork Red River aquifer study area, southwest Oklahoma

4. Mean annual reported groundwater use by type for the North Fork Red River aquifer, 1967-2013

5. Statistical summary of reported yields of wells completed in the North Fork Red River aquifer, 1936-2015.

6. Statistical summary of groundwater-quality data from 20 wells completed in the North Fork Red River aquifer, July-August 2014

7. Hydraulic properties calculated from hydraulic profiling tool test holes and multi-well aquifer tests in the North Fork Red River aquifer

8. Conceptual groundwater-flow model mean annual water budget for the North Fork Red River aquifer, 1980-2013

9. Observation group contribution to the objective function for the automated calibration of the numerical groundwater-flow model of the North Fork Red River aquifer, 1980-2013

10. Statistical summary of aquifer thickness, saturated thickness, and hydraulic properties for the calibrated numerical groundwater-flow model of the North Fork Red River aquifer, 1980-2013

11. Statistical summary of water-table-altitude residuals for the numerical groundwater-flow model of the North Fork Red River aquifer, 1980-2013

12. Statistical summary of base-flow residuals for the numerical groundwater-flow model of the North Fork Red River aquifer, 1980-2013

13. Statistical summary of lake-stage residuals for the numerical groundwater-flow model of the North Fork Red River aquifer, 1980-2013

14. Mean annual water budget for the numerical groundwater-flow model of the North Fork Red River aquifer, 1980-2013

15. Equal-proportionate-share pumping rates for the North Fork Red River aquifer, southwest Oklahoma

16. Changes in groundwater storage and mean annual base flow after 50 years of groundwater pumping at selected rates for the North Fork Red River aquifer, southwest Oklahoma 


\section{Conversion Factors}

U.S. customary units to International System of Units

\begin{tabular}{|c|c|c|}
\hline Multiply & By & To obtain \\
\hline \multicolumn{3}{|c|}{ Length } \\
\hline inch (in.) & 2.54 & centimeter $(\mathrm{cm})$ \\
\hline inch (in.) & 25.4 & millimeter (mm) \\
\hline foot (ft) & 0.3048 & meter (m) \\
\hline mile (mi) & 1.609 & kilometer $(\mathrm{km})$ \\
\hline \multicolumn{3}{|c|}{ Area } \\
\hline acre & 4,047 & square meter $\left(\mathrm{m}^{2}\right)$ \\
\hline acre & 0.4047 & hectare (ha) \\
\hline acre & 0.4047 & square hectometer $\left(\mathrm{hm}^{2}\right)$ \\
\hline acre & 0.004047 & square kilometer $\left(\mathrm{km}^{2}\right)$ \\
\hline square mile $\left(\mathrm{mi}^{2}\right)$ & 259.0 & hectare (ha) \\
\hline square mile $\left(\mathrm{mi}^{2}\right)$ & 2.590 & square kilometer $\left(\mathrm{km}^{2}\right)$ \\
\hline \multicolumn{3}{|c|}{ Volume } \\
\hline acre-foot (acre-ft) & 1,233 & cubic meter $\left(\mathrm{m}^{3}\right)$ \\
\hline acre-foot (acre-ft) & 0.001233 & cubic hectometer $\left(\mathrm{hm}^{3}\right)$ \\
\hline \multicolumn{3}{|c|}{ Flow rate } \\
\hline acre-foot per year (acre-ft/yr) & 1,233 & cubic meter per year $\left(\mathrm{m}^{3} / \mathrm{yr}\right)$ \\
\hline acre-foot per year (acre-ft/yr) & 0.001233 & cubic hectometer per year $\left(\mathrm{hm}^{3} / \mathrm{yr}\right)$ \\
\hline foot per second (ft/s) & 0.3048 & meter per second (m/s) \\
\hline foot per day (ft/d) & 0.3048 & meter per day (m/d) \\
\hline foot per year (ft/yr) & 0.3048 & meter per year (m/yr) \\
\hline cubic foot per second $\left(\mathrm{ft}^{3} / \mathrm{s}\right)$ & 0.02832 & cubic meter per second $\left(\mathrm{m}^{3} / \mathrm{s}\right)$ \\
\hline cubic foot per day $\left(\mathrm{ft}^{3} / \mathrm{d}\right)$ & 0.02832 & cubic meter per day (m³/d) \\
\hline gallon per minute (gal/min) & 0.06309 & liter per second (L/s) \\
\hline inch per year (in/yr) & 25.4 & millimeter per year (mm/yr) \\
\hline mile per hour (mi/h) & 1.609 & kilometer per hour $(\mathrm{km} / \mathrm{h})$ \\
\hline \multicolumn{3}{|c|}{ Hydraulic conductivity } \\
\hline foot per day (ft/d) & 0.3048 & meter per day (m/d) \\
\hline \multicolumn{3}{|c|}{ Hydraulic gradient } \\
\hline foot per mile (ft/mi) & 0.1894 & meter per kilometer $(\mathrm{m} / \mathrm{km})$ \\
\hline \multicolumn{3}{|c|}{ Transmissivity } \\
\hline foot squared per day $\left(\mathrm{ft}^{2} / \mathrm{d}\right)$ & 0.09290 & meter squared per day (m²/d) \\
\hline \multicolumn{3}{|c|}{ Leakance } \\
\hline foot per day per foot $[(\mathrm{ft} / \mathrm{d}) / \mathrm{ft}]$ & 1 & meter per day per meter \\
\hline
\end{tabular}

Temperature in degrees Celsius $\left({ }^{\circ} \mathrm{C}\right)$ may be converted to degrees Fahrenheit $\left({ }^{\circ} \mathrm{F}\right)$ as ${ }^{\circ} \mathrm{F}=\left(1.8 \times{ }^{\circ} \mathrm{C}\right)+32$.

Temperature in degrees Fahrenheit $\left({ }^{\circ} \mathrm{F}\right)$ may be converted to degrees Celsius $\left({ }^{\circ} \mathrm{C}\right)$ as ${ }^{\circ} \mathrm{C}=\left({ }^{\circ} \mathrm{F}-32\right) / 1.8$. 


\section{Datum}

Vertical coordinate information is referenced to the North American Vertical Datum of 1988 (NAVD 88).

Horizontal coordinate information is referenced to the North American Datum of 1983 (NAD 83).

Altitude, as used in this report, refers to distance above the vertical datum.

\section{Supplemental Information}

Transmissivity: The standard unit for transmissivity is cubic foot per day per square foot times foot of aquifer thickness $\left[\left(\mathrm{ft}^{3} / \mathrm{d}\right) / \mathrm{ft}^{2}\right] \mathrm{ft}$. In this report, the mathematically reduced form, foot squared per day $\left(\mathrm{ft}^{2} / \mathrm{d}\right)$, is used for convenience.

Specific conductance is given in microsiemens per centimeter at 25 degrees Celsius $(\mu \mathrm{S} / \mathrm{cm}$ at $\left.25^{\circ} \mathrm{C}\right)$.

Concentrations of chemical constituents in water are given in either milligrams per liter (mg/L) or micrograms per liter $(\mu \mathrm{g} / \mathrm{L})$.

\section{Abbreviations}

$\begin{array}{ll}\text { BFI } & \text { base-flow index } \\ \text { DEM } & \text { digital elevation model } \\ \text { EFRR } & \text { Elm Fork Red River inflow for Streamflow-Routing package } \\ \text { ELK } & \text { Elk Creek inflow for Streamflow-Routing package } \\ \text { EPS } & \text { equal proportionate share } \\ \text { ET } & \text { evapotranspiration } \\ \text { GHB } & \text { general-head boundary } \\ \text { HPT } & \text { Hydraulic Profiling Tool } \\ \text { IDW } & \text { inverse distance weighted } \\ \text { Kh } & \text { horizontal hydraulic conductivity } \\ \text { LAID } & \text { Lugert-Altus Irrigation District } \\ \text { MAY } & \text { maximum annual yield } \\ \text { NFRR } & \text { North Fork Red River inflow for Streamflow-Routing package } \\ \text { NWIS } & \text { National Water Information System } \\ \text { OWRB } & \text { Oklahoma Water Resources Board } \\ \text { RMSE } & \text { root-mean-square error } \\ \text { SFR } & \text { streamflow routing }\end{array}$




$\begin{array}{ll}\text { SWB } & \text { soil-water balance } \\ \text { SWEE } & \text { Sweetwater Creek inflow for Streamflow-Routing package } \\ \text { Sy } & \text { specific yield } \\ \text { TDS } & \text { total dissolved solids } \\ \text { USGS } & \text { U.S. Geological Survey } \\ \text { WTF } & \text { water-table fluctuation }\end{array}$




\title{
Hydrogeology and Simulated Groundwater Flow and Availability in the North Fork Red River Aquifer, Southwest Oklahoma, 1980-2013
}

\author{
By S. Jerrod Smith, ${ }^{1}$ John H. Ellis, ${ }^{1}$ Derrick L. Wagner, ${ }^{2}$ and Steven M. Peterson'
}

\section{Abstract}

On September 8, 1981, the Oklahoma Water Resources Board established regulatory limits on the maximum annual yield of groundwater (343,042 acre-feet per year) and equalproportionate-share (EPS) pumping rate (1.0 acre-foot per acre per year) for the North Fork Red River aquifer. The maximum annual yield and EPS were based on a hydrologic investigation that used a numerical groundwater-flow model to evaluate the effects of potential groundwater withdrawals on groundwater availability in the North Fork Red River aquifer. The Oklahoma Water Resources Board is statutorily required (every 20 years) to update the hydrologic investigation on which the maximum annual yield and EPS were based. Because 20 years have elapsed since the final order was issued, the U.S. Geological Survey, in cooperation with the Oklahoma Water Resources Board, conducted an updated hydrologic investigation and evaluated the effects of potential groundwater withdrawals on groundwater flow and availability in the North Fork Red River aquifer in Oklahoma. This report describes a hydrologic investigation of the North Fork Red River aquifer that includes an updated summary of the aquifer hydrogeology. As part of this investigation, groundwater flow and availability were simulated by using a numerical groundwater-flow model.

The North Fork Red River aquifer in Beckham, Greer, Jackson, Kiowa, and Roger Mills Counties in Oklahoma is composed of about 777 square miles (497,582 acres) of alluvium and terrace deposits along the North Fork Red River and tributaries, including Sweetwater Creek, Elk Creek, Otter Creek, and Elm Fork Red River. The North Fork Red River is the primary source of surface-water inflow to Lake Altus, which overlies the North Fork Red River aquifer. Lake Altus is a U.S. Bureau of Reclamation reservoir with the primary purpose of supplying irrigation water to the Lugert-Altus Irrigation District.

A hydrogeologic framework was developed for the North Fork Red River aquifer and included a definition of the aquifer

${ }^{1}$ U.S. Geological Survey.

${ }^{2}$ Oklahoma Water Resources Board. extent and potentiometric surface, as well as a description of the textural and hydraulic properties of aquifer materials. The hydrogeologic framework was used in the construction of a numerical groundwater-flow model of the North Fork Red River aquifer described in this report. A conceptual model of aquifer inflows and outflows was developed for the North Fork Red River aquifer to constrain the construction and calibration of a numerical groundwater-flow model that reasonably represented the groundwater-flow system. The conceptualmodel water budget estimated mean annual inflows to and outflows from the North Fork Red River aquifer for the period 1980-2013 and included a sub-accounting of mean annual inflows and outflows for the portions of the aquifer that were upgradient and downgradient from Lake Altus. The numerical groundwater-flow model simulated the period 1980-2013 and was calibrated to water-table-altitude observations at selected wells, monthly base flow at selected streamgages, net streambed seepage as estimated for the conceptual model, and Lake Altus stage.

Groundwater-availability scenarios were performed by using the calibrated numerical groundwater-flow model to (1) estimate the EPS pumping rate that guarantees a minimum 20-, 40-, and 50-year life of the aquifer, (2) quantify the potential effects of projected well withdrawals on groundwater storage over a 50-year period, and (3) simulate the potential effects of a hypothetical (10-year) drought on base flow and groundwater storage. The results of the groundwateravailability scenarios could be used by the Oklahoma Water Resources Board to reevaluate the maximum annual yield of groundwater from the North Fork Red River aquifer.

EPS scenarios for the North Fork Red River aquifer were run for periods of 20, 40, and 50 years. The 20-, 40-, and 50-year EPS pumping rates under normal recharge conditions were $0.59,0.52$, and 0.52 acre-foot per acre per year, respectively. Given the 497,582-acre aquifer area, these rates correspond to annual yields of about 294,000, 259,000, and 259,000 acre-feet per year, respectively. Groundwater storage at the end of the 20-year EPS scenario was about 951,000 acre-feet, or about 1,317,000 acre-feet (58 percent) less than the starting EPS scenario storage. This decrease in storage was equivalent to a mean water-level decline of about 22 feet. Most areas of the active alluvium near the North Fork 
Hydrogeology and Simulated Groundwater Flow and Availability in the North Fork Red River Aquifer, Southwest Okla.

Red River, Elk Creek, and Elm Fork Red River remained partially saturated through the end of the EPS scenario because of streambed seepage. Lake Altus storage was reduced to zero after 6-7 years of EPS pumping in each scenario.

Projected 50-year pumping scenarios were used to simulate the effects of selected well withdrawal rates on groundwater storage of the North Fork Red River aquifer and base flows in the North Fork Red River upstream from Lake Altus. The effects of well withdrawals were evaluated by comparing changes in groundwater storage and base flow between four 50 -year scenarios using (1) no groundwater pumping, (2) mean pumping rates for the study period (19802013), (3) 2013 pumping rates, and (4) increasing demand pumping rates. The increasing demand pumping rates assumed a 20.4-percent increase in pumping over 50 years based on 2010-60 demand projections for southwest Oklahoma.

Groundwater storage after 50 years with no pumping was about 2,606,000 acre-feet, or 137,000 acre-feet (5.5 percent) greater than the initial groundwater storage; this groundwater storage increase is equivalent to a mean water-level increase of 2.3 feet. Groundwater storage after 50 years with the mean pumping rate for the study period (1980-2013) was about 2,476,000 acre-feet, or about 7,000 acre-feet (0.3 percent) greater than the initial groundwater storage; this groundwater storage increase is equivalent to a mean water-level increase of 0.1 foot. Groundwater storage at the end of the 50-year period with 2013 pumping rates was about 2,398,000 acrefeet, or about 70,000 acre-feet (2.8 percent) less than the initial storage; this groundwater storage decrease is equivalent to a mean water-level decline of 1.2 feet. Groundwater storage at the end of the 50-year period with increasing demand pumping rates was about 2,361,000 acre-feet, or about 107,000 acrefeet (4.3 percent) less than the initial storage; this groundwater storage decrease is equivalent to a mean water-level decline of 1.8 feet. Mean annual base flow simulated at the Carter streamgage (07301500) on North Fork Red River increased by about 4,000 acre-feet ( 10 percent) after 50 years with no pumping and decreased by about 5,400 acre-feet (13 percent) after 50 years with increasing demand pumping rates. Mean annual base flow simulated at the North Fork Red River inflow to Lake Altus increased by about 7,400 acre-feet (15 percent) after 50 years with no pumping and decreased by about 5,800 acre-feet (12 percent) after 50 years with increasing demand pumping rates.

A hypothetical 10-year drought scenario was used to simulate the effects of a prolonged period of reduced recharge on groundwater storage and Lake Altus stage and storage. Drought effects were quantified by comparing the results of the drought scenario to those of the calibrated numerical model (no drought). To simulate the hypothetical drought, recharge in the calibrated numerical model was reduced by 50 percent during the simulated drought period (1984-1993). Groundwater storage at the end of the drought period was about 2,271,000 acre-feet, or about 426,000 acrefeet (15.8 percent) less than the groundwater storage of the calibrated numerical model. This decrease in groundwater storage is equivalent to a mean water-table-altitude decline of 7.1 feet. At the end of the 10-year hypothetical drought period, base flows at the Sweetwater (07301420), Carter (07301500), Headrick (07305000), and Snyder (07307010) streamgages had decreased by about 37, 61, 44, and 45 percent, respectively. The minimum Lake Altus storage simulated during the drought period was 403 acre-feet, which was a decline of 92 percent from the nondrought storage. Reduced base flows in the North Fork Red River were the primary cause of Lake Altus storage declines.

\section{Introduction}

The 1973 Oklahoma Water Law (82 OK Stat $\S 82-1020.5)$ requires the Oklahoma Water Resources Board (OWRB) to conduct hydrologic investigations of the State's aquifers (called groundwater basins) to support a determination of the maximum annual yield (MAY) for each groundwater basin. The MAY is defined as the amount of fresh groundwater that can be withdrawn annually while ensuring a minimum 20-year life of the groundwater basin (OWRB, 2010). For alluvium and terrace aquifers, the groundwaterbasin-life requirement is satisfied if, after 20 years of MAY withdrawals, 50 percent of the groundwater basin retains a saturated thickness of at least $5 \mathrm{ft}$. When a MAY has been established, the amount of land owned or leased by a permit applicant determines the annual volume of water allocated to that permit applicant. The annual volume of water allocated per acre of land is known as the equal-proportionate-share (EPS) pumping rate.

The OWRB issued a final order on September 8, 1981, that established the MAY (343,042 acre-feet per year [acre-ft/yr]) and EPS pumping rate (1.0 acre-foot per acre per year) for the North Fork Red River aquifer (OWRB, 2015a). The MAY and EPS were based on hydrologic investigations by Kent (1980) and Paukstaitis (1981) that used a numerical groundwater-flow model (Trescott and others, 1976) to evaluate the effects of potential groundwater withdrawals on groundwater availability in the North Fork Red River aquifer. Every 20 years, the OWRB is statutorily required to update the hydrologic investigation on which the MAY and EPS were based. Because 20 years have elapsed since the final order was issued, the U.S. Geological Survey (USGS), in cooperation with the OWRB, conducted an updated hydrologic investigation and evaluated the effects of potential groundwater withdrawals on groundwater flow and availability in the North Fork Red River aquifer.

\section{Purpose and Scope}

The purpose of this report is to describe a hydrologic investigation of the North Fork Red River aquifer that includes an updated summary of the aquifer hydrogeology and results of the simulation of groundwater flow and availability 
obtained by using a numerical groundwater-flow model. The numerical groundwater-flow model was calibrated to observed data and used to compute a mean annual water budget for the study period 1980-2013. Groundwater-availability scenarios were performed by using the calibrated numerical groundwater-flow model to (1) estimate the EPS pumping rate that guarantees a minimum 20-, 40-, and 50-year life of the aquifer, (2) quantify the potential effects of projected well withdrawals on groundwater storage over a 50-year period, and (3) simulate the potential effects of a hypothetical (10year) drought on groundwater storage and lake storage. The results of the groundwater-availability scenarios could be used by the OWRB to reevaluate the MAY of groundwater from the North Fork Red River aquifer in Oklahoma. The calibrated numerical groundwater-flow model and groundwateravailability scenarios were archived and released in Smith and others (2017).

The geographic scope of the hydrologic investigation is the alluvium and terrace deposits of the North Fork Red River aquifer and the underlying Permian bedrock units. Though the alluvium and terrace deposits of the North Fork Red River and Sweetwater Creek extend west into Texas, this investigation was focused on the OWRB jurisdictional extent of the North Fork Red River aquifer in Beckham, Greer, Jackson, Kiowa, and Roger Mills Counties of southwest Oklahoma (fig. 1). The alluvium and terrace deposits of the North Fork Red River also extend south into Tillman County, Oklahoma, where they are known as the Tillman Terrace aquifer (fig. 1); the Tillman Terrace aquifer was not included in the investigation described in this report because the OWRB manages that aquifer separately from the North Fork Red River aquifer.

\section{Description of Study Area}

The North Fork Red River aquifer in Beckham, Greer, Jackson, Kiowa, and Roger Mills Counties in Oklahoma is composed of about 777 square miles $\left(\mathrm{mi}^{2}\right)(497,582$ acres $)$ of alluvium and terrace deposits along the North Fork Red River. This area includes alluvium and terrace deposits along several major tributaries to the North Fork Red River including Sweetwater Creek, Elk Creek, Otter Creek, and Elm Fork Red River in southwest Oklahoma (fig. 1). The North Fork Red River and tributaries, which compose the North Fork Red River watershed, drain about 4,500 $\mathrm{mi}^{2}$ of land area in Texas and Oklahoma before connecting with the Red River (fig. 2). Groundwater discharge from the North Fork Red River aquifer sustains streamflow to the North Fork Red River during most of the year (Smith and Wahl, 2003); however, some gaged reaches of the North Fork Red River and tributaries commonly have no flow (defined as streamflow less than 1 cubic foot per second $\left[\mathrm{ft}^{3} / \mathrm{s}\right]$ ) in the late summer when water demands for irrigation, public supply, and evapotranspiration (ET) are greatest. The Carter streamgage (07301500; fig. 1, table 1, at end of report) on the North Fork Red River, for example, recorded no flow from June 6, 2011, to January 6, 2012, during a 7-month period of exceptional drought (USGS, 2015a). Though a few storms in that period produced enough runoff to sustain streamflow for a few hours, no day in that period had daily streamflow greater than $1 \mathrm{ft}^{3} / \mathrm{s}$.

The North Fork Red River is the primary source of surface-water inflow to Lake Altus, a U.S. Bureau of Reclamation reservoir with the primary purpose of supplying irrigation water to the Lugert-Altus Irrigation District (LAID) (fig. 2). Lake Altus supplies a dependable annual yield of 47,100 acre-ft/yr but is over-allocated with permitted surfacewater withdrawals of 85,630 acre-ft/yr to the LAID and 4,800 acre-ft/yr to the city of Altus (OWRB, 2012a). For the study period 1980-2013, about half of the annual surfacewater inflow to Lake Altus was supplied by base flow (as observed at the Carter streamgage [07301500] and computed by using the USGS Groundwater Toolbox [Barlow and others, 2015]), which is the component of streamflow supplied by the discharge of groundwater to streams (Barlow and Leake, 2012) (table 2). However, the total annual base flow and the base-flow index (the ratio of total annual base flow to total annual streamflow) generally have been increasing (while peak flows generally have been decreasing) since the 1960s at the Carter streamgage (07301500), just upstream from Lake Altus (Smith and Wahl, 2003; Esralew and Lewis, 2010). The reasons for these increasing trends in base flow and base-flow index are not clear but could include increases in the number of impoundments (stock ponds and floodwaterretarding structures) or changes in agricultural practices that reduce runoff and promote artificial recharge to the aquifer (Smith and Wahl, 2003). In recent years (2000-13) at the Carter streamgage (07301500), the base-flow index exceeded 60 percent in 4 out of 14 years with a maximum base-flow index of 81.1 percent in 2011 (table 2).

Elk Creek (through Bretch Canal) and West Otter Creek supply inflow to Tom Steed Reservoir, a U.S. Bureau of Reclamation reservoir that provides water (16,100 acre-ft/ yr, permitted) to the Oklahoma cities of Altus, Snyder, and Frederick, as well as the Hackberry Flat Wildlife Management Area (U.S. Bureau of Reclamation, 2015a; fig. 2). During times of runoff, surplus water is diverted from Elk Creek through the Bretch Canal to augment supply at Tom Steed Reservoir (fig. 2). Unlike Lake Altus, which is dependent on base flows from the North Fork Red River aquifer for replenishment, Tom Steed Reservoir is near the edge of the aquifer and primarily is replenished by surface-water runoff from areas outside of the North Fork Red River aquifer. Base flows in Elk Creek originate from several sources including the Elk City aquifer, the North Fork Red River aquifer, and, following periods of runoff, numerous floodwater-retarding structures in the Elk Creek watershed (figs. 1-2). 


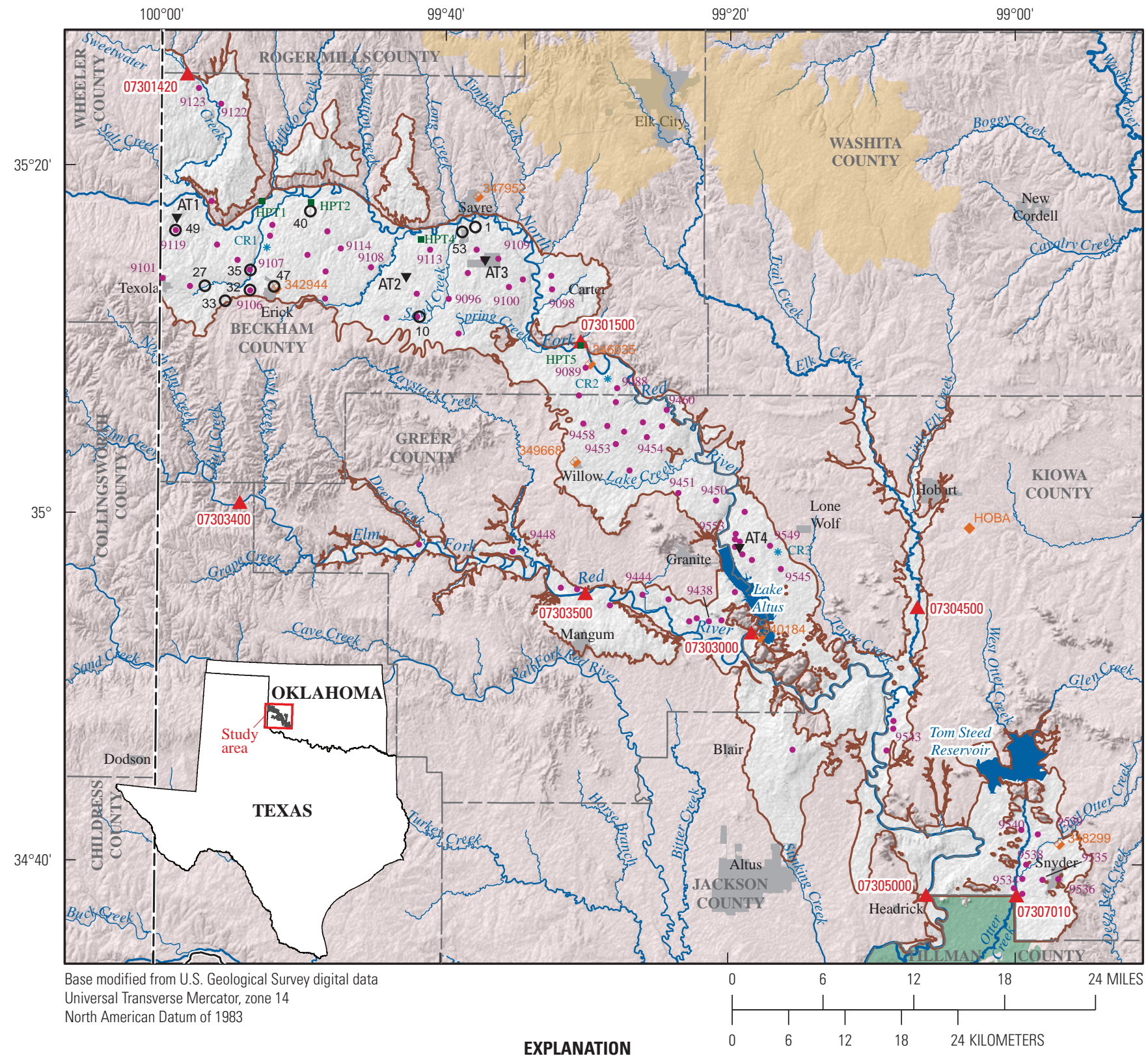

EXPLANATION

Incorporated area (U.S. Census Bureau, 2000)

North Fork Red River aquifer boundary (modified from Oklahoma Water Resources Board, 2015b)

Tillman Terrace aquifer (Oklahoma Water Resources Board, 2015b)

Elk City aquifer (Oklahoma Water Resources Board, 2015b)

Climate station (table 1)

National Climatic Data Center (2015)

- Oklahoma Mesonet (2015)

* Continuous water-level recorder well (U.S. Geological Survey, 2015a; table 1)

$\nabla$ Multi-well aquifer test location (table 1)

- Geoprobe hydraulic profiling tool test hole (table 1)

- Water-table-altitude observation and Mass Measurement Program well (Oklahoma Water Resources Board, 2015b; table 1, only wells discussed in this report are labeled)

- Historical water-table altitude observation well (U.S. Geological Survey, 2015a; table 1)

A Streamgage (U.S. Geological Survey, 2015a; table 1)

Figure 1. The North Fork Red River aquifer study area, southwest Oklahoma. 


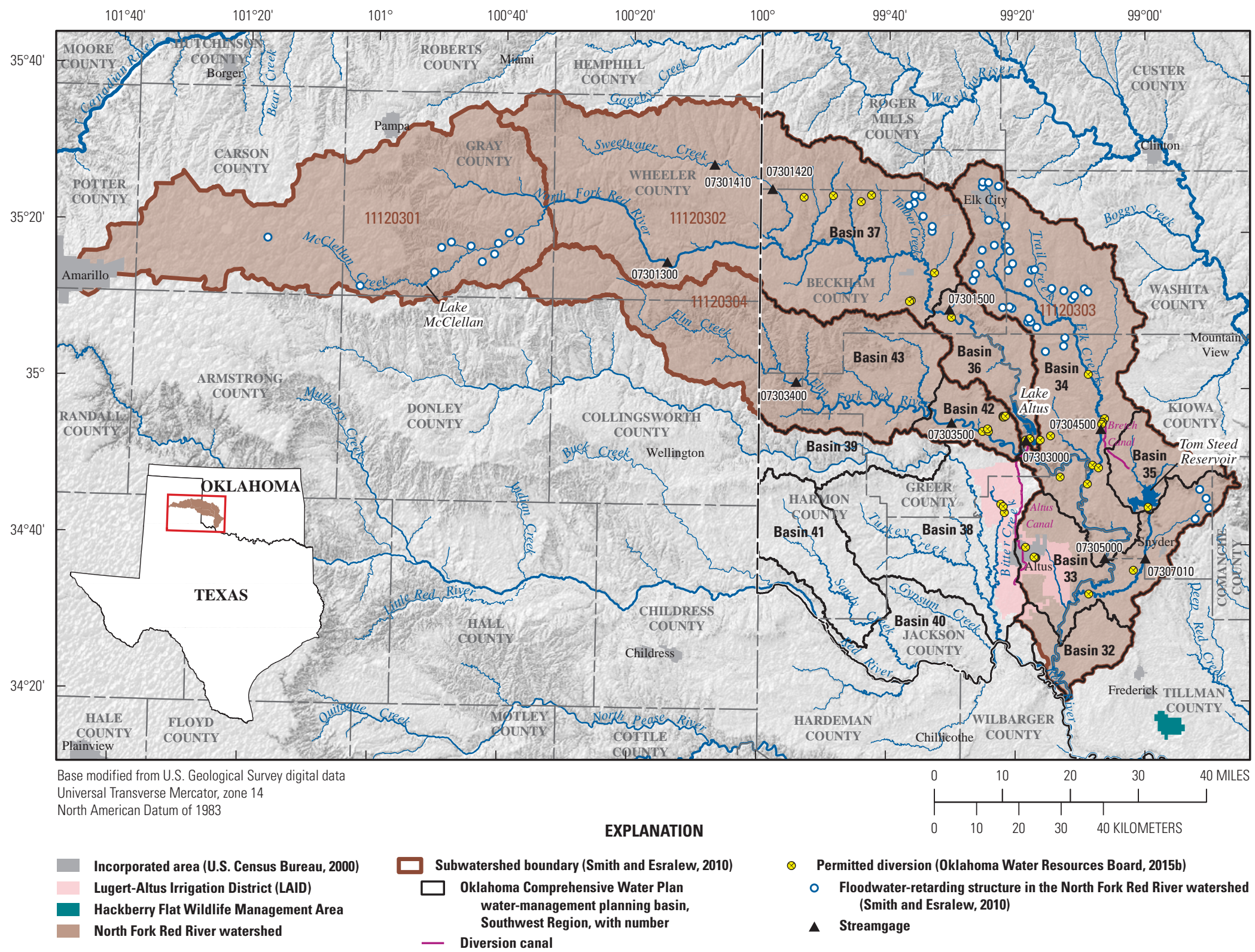

- Diversion canal

- Streamgage 
Table 2. Mean annual streamflow and mean annual base flow for selected streamgages in and near the North Fork Red River aquifer study area, 1980-2013.

[Base flow computed by using BFI method in the U.S. Geological Survey Groundwater Toolbox (Barlow and others, 2015; streamflow data from U.S. Geological Survey, 2015a); Mean Lake Altus releases were assumed to be the same as mean streamflow at the Lugert streamgage; $\mathrm{ft}^{3} / \mathrm{s}$, cubic feet per second; acre-ft/yr, acre-feet per year; \%, percent; BFI, base-flow index; --, data not available or not applicable]

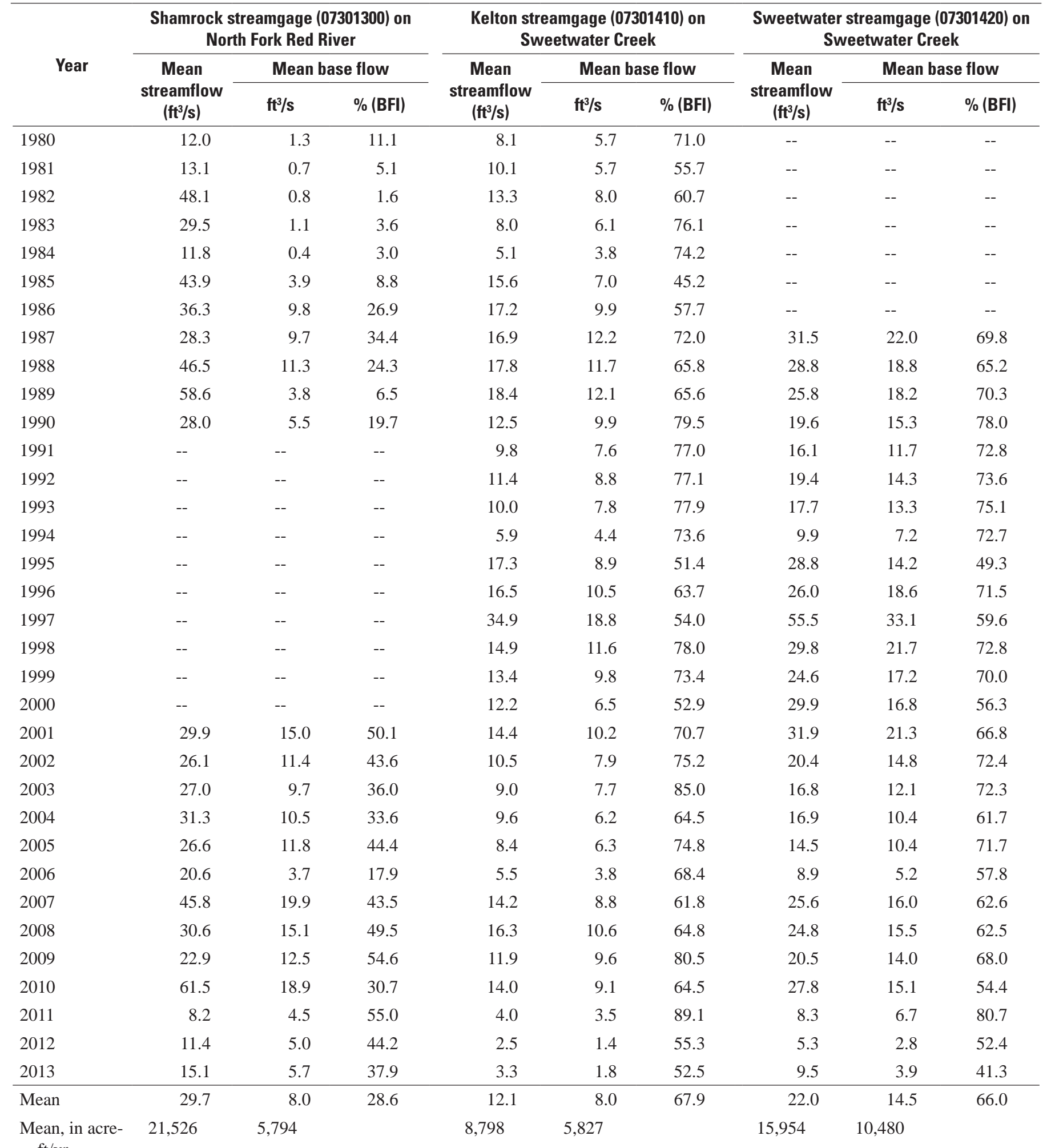
$\mathrm{ft} / \mathrm{yr}$ 
Table 2. Mean annual streamflow and mean annual base flow for selected streamgages in and near the North Fork Red River aquifer study area, 1980-2013.-Continued

[Base flow computed by using BFI method in the U.S. Geological Survey Groundwater Toolbox (Barlow and others, 2015; streamflow data from U.S. Geological Survey, 2015a); Mean Lake Altus releases were assumed to be the same as mean streamflow at the Lugert streamgage; $\mathrm{ft}^{3} / \mathrm{s}$, cubic feet per second; acre-ft/yr, acre-feet per year; \%, percent; BFI, base-flow index; --, data not available or not applicable]

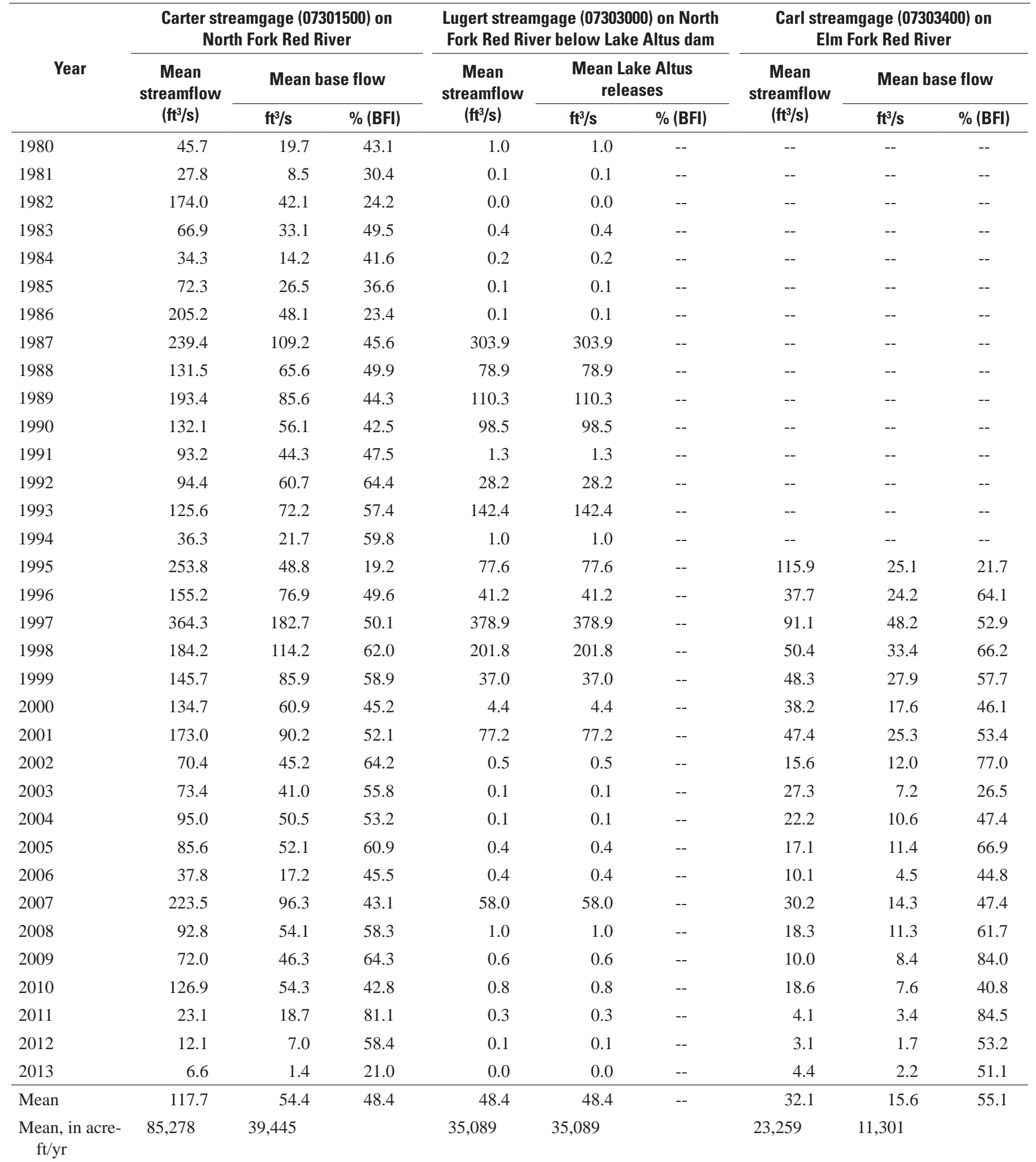


Table 2. Mean annual streamflow and mean annual base flow for selected streamgages in and near the North Fork Red River aquifer study area, 1980-2013.-Continued

[Base flow computed by using BFI method in the U.S. Geological Survey Groundwater Toolbox (Barlow and others, 2015; streamflow data from U.S. Geological Survey, 2015a); Mean Lake Altus releases were assumed to be the same as mean streamflow at the Lugert streamgage; $\mathrm{ft}^{3} / \mathrm{s}$, cubic feet per second; acre-ft/yr, acre-feet per year; \%, percent; BFI, base-flow index; --, data not available or not applicable]

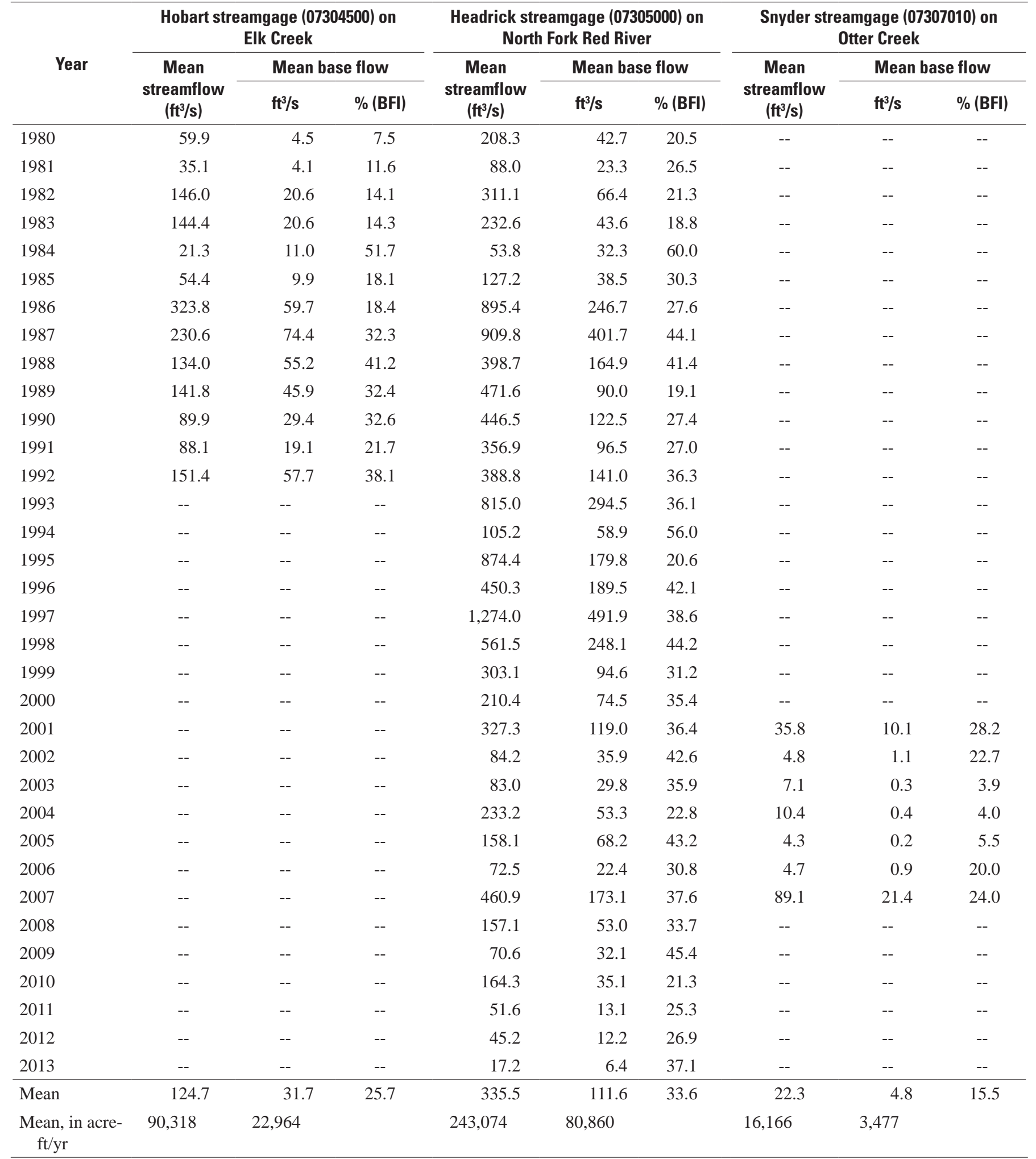


The 2012 Oklahoma Comprehensive Water Plan prioritized 12 water-management planning basins where water-supply shortages were most likely to occur by 2060 based on available hydrologic data and projected demands; 3 of the 12 prioritized water-management planning basins (34, which includes Elk Creek; 36, which includes Lake Altus; and 42, which includes part of the Elm Fork Red River; fig. 2) are in the North Fork Red River watershed. Surfacewater resources are fully allocated in water-management planning basins 34, 36, and 42, and physical and chemical resource limitations in these basins were projected to cause surface-water shortages by 2020, 2050, and 2050, respectively (OWRB, 2012b, p. 116-118). Water-management planning basin 36, which encompasses a portion of the North Fork Red River aquifer upgradient from Lake Altus, was identified as the Oklahoma water-management planning basin most susceptible to shortages in alluvium and terrace groundwater by 2060 . Water-management planning basin 42 , which encompasses a portion of the North Fork Red River aquifer along the Elm Fork Red River, was identified as the second most susceptible to shortages in alluvium and terrace groundwater by 2060 .

\section{Climate Characteristics and Trends}

The climate of the North Fork Red River aquifer study area is classified as humid subtropical (Kottek and others, 2006). Daily maximum temperatures usually exceed 100 degrees Fahrenheit $\left({ }^{\circ} \mathrm{F}\right)$ for 20 to 35 days in summer, and the maximum recorded temperature was $120^{\circ} \mathrm{F}$ at Altus in 1936 (Oklahoma Climatological Survey, 2015a). The period of greatest monthly precipitation usually occurs in May and June, and a secondary period of greater precipitation often occurs in September and October. Monthly precipitation usually is least in the winter months when snow totals of 1 to 10 inches (in.) are common (Oklahoma Climatological Survey, 2015a). Winds average about 10 miles per hour annually and are prevailingly from the south and southeast (Oklahoma Climatological Survey, 2015a).

Historical data from selected climate stations in southwest Oklahoma (climate division 7) have been quality assured, bias-corrected, and summarized monthly as part of the U.S. Historical Climatology Network (National Climatic Data Center, 2015; fig. 3, table 3). The monthly summarized data were used to calculate and graph annual and monthly temperature and precipitation statistics for the study area, and the data from some individual climate stations (National Climatic Data Center, 2015; Oklahoma Climatological Survey, 2015a) were summarized to show the variability of these statistics within the study area. A lowess smooth line (Cleveland, 1979) was used to delineate periods of below- and above-average precipitation.

The mean annual precipitation in the study area for the period of record 1895-2015 was about 27.6 inches per year (in/yr) (fig. 3A, table 3). A relatively long dry period occurred in 1930-80 with 33 of 51 years (65 percent) recording below-average precipitation. Within this dry period, years were grouped into four 5- to 12-year spans of below-average precipitation punctuated by 3- to 5-year spans of aboveaverage precipitation. The period 1981-2000 was a historically unprecedented wet period in which 16 of 20 years (80 percent) had above-average precipitation (fig. 3A). The period 2010-14 was noteworthy as an exceptionally dry period.

The mean annual temperature in the study area for the period of record $1895-2015$ was about $61.2^{\circ} \mathrm{F}$ (fig. 3B, table 3). Mean annual temperatures increase to the southeast from about $60^{\circ} \mathrm{F}$ at the Erick climate station in Beckham County to about $62{ }^{\circ} \mathrm{F}$ at the Altus Dam climate station in Kiowa County.

The mean annual temperature was about $0.4^{\circ} \mathrm{F}$ greater and the mean annual precipitation was about $1.6 \mathrm{in} / \mathrm{yr}$ greater for the study period 1980-2013 compared to the period of record (table 3). Over the study period, the annual mean precipitation was greater than the mean for the period of record in 20 of 34 years. The 20-year wet period 1981-2000 and the 17-year (and continuing) warm period 1996-2013 were unprecedented in the period of record (fig. 3). The mean monthly precipitation for the study period 1980-2013 was greatest (4.2 in.) in May and least (1.1 in.) in January (fig. 4A). The mean monthly temperature for the study period 1980 2013 was greatest $\left(84^{\circ} \mathrm{F}\right)$ in July and least $\left(39^{\circ} \mathrm{F}\right)$ in January (fig. 4B).

Multi-year to decadal droughts are not uncommon for the study area. The 1929-41 ("Dust Bowl”), 1952-56, and 1961-72 drought periods were among the most severe in the 20th century; a shorter and less severe 1976-81 drought period also occurred in the late 20th century. The 21st century began with the drought periods 2002-06 and 2010-14 (Tortorelli, 2008; Shivers and Andrews, 2013) (fig. 3A). The most severe of these droughts developed from extended periods of belowaverage precipitation paired with above-average temperature. The precipitation and temperature characteristics of the 1952-56 drought period were similar to those of the 2010-14 drought period, and the effects of these drought periods on aquifer water levels also were comparable (fig. 3).

Climate models used by the Climate Model

Intercomparison Program predict about a $5-^{\circ} \mathrm{F}$ increase in annual minimum and maximum temperatures in the study area between the historical period 1950-2005 and the future period 2050-74 (Alder and Hostetler, 2013). These climate models also predict a slight decrease in mean annual precipitation between the historical period 1950-2005 and the future period 2050-74 (Alder and Hostetler, 2013). If these predictions come to pass, they are likely to cause increased water demand, especially for irrigation; more water would be required to grow the same crops under the predicted warmer and drier climate conditions. 

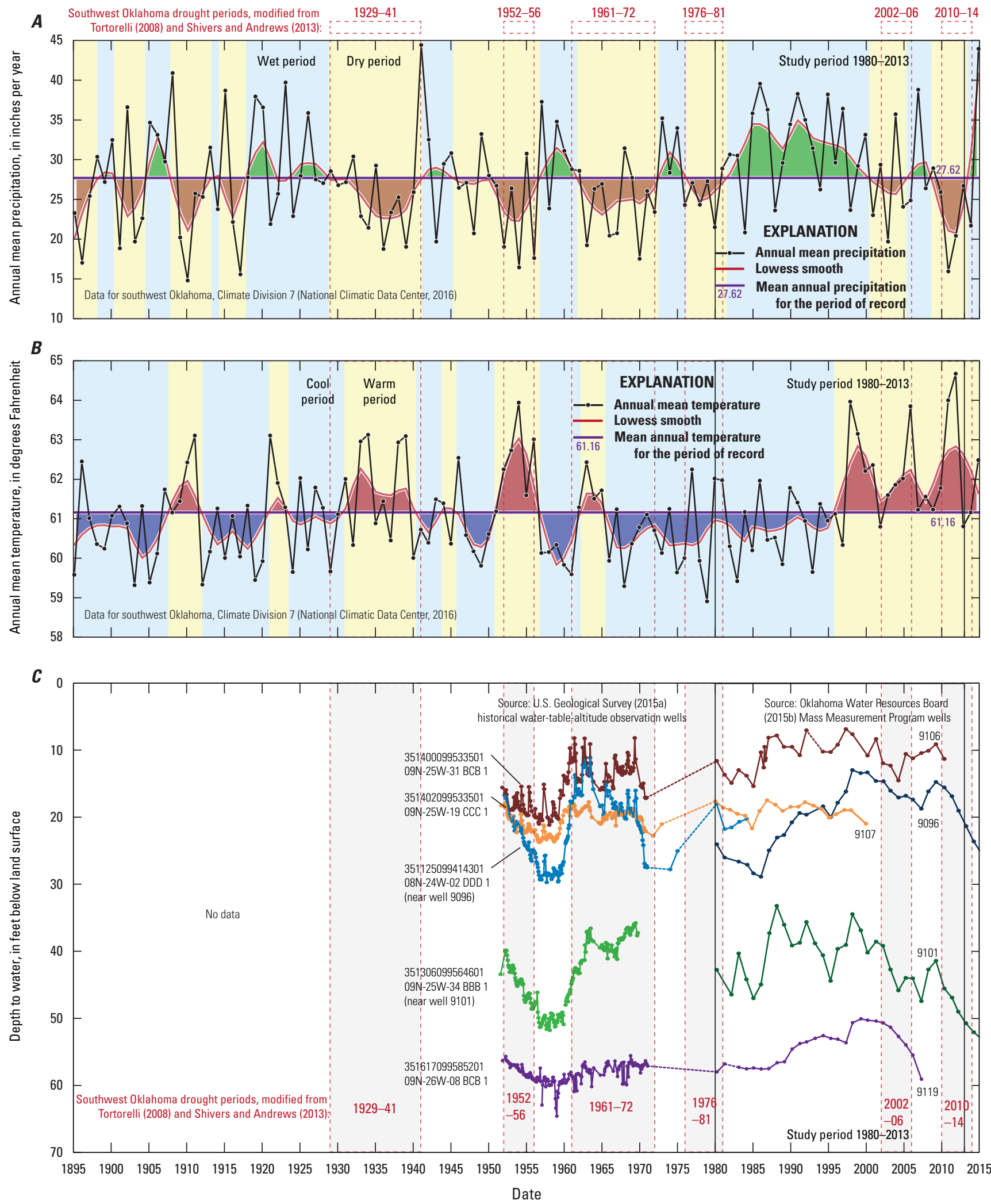

Figure 3. $A$, Annual mean precipitation; $B$, annual mean temperature; and $C$, depth to water in selected wells, southwest Oklahoma, 1895-2015. 
Table 3. Mean annual precipitation and mean annual temperature data summaries from selected regions and stations in and near the North Fork Red River aquifer study area, southwest Oklahoma.

[F, degrees Fahrenheit; --, data not available or not used]

\begin{tabular}{|c|c|c|c|c|c|c|c|c|c|}
\hline \multirow{2}{*}{$\begin{array}{c}\text { Region or } \\
\text { station number }\end{array}$} & \multirow{2}{*}{$\begin{array}{c}\text { Region or } \\
\text { station name }\end{array}$} & \multirow{2}{*}{$\begin{array}{l}\text { Period of } \\
\text { record }^{1}\end{array}$} & \multirow{2}{*}{$\begin{array}{l}\text { Number } \\
\text { of years }\end{array}$} & \multicolumn{3}{|c|}{$\begin{array}{c}\text { Mean annual precipitation } \\
\text { (inches per year) }\end{array}$} & \multicolumn{3}{|c|}{$\begin{array}{l}\text { Mean annual temperature } \\
\left({ }^{\circ} \mathrm{F}\right)\end{array}$} \\
\hline & & & & 1947-79 & 1980-2013 & $\begin{array}{l}\text { Period of } \\
\text { record }\end{array}$ & 1947-79 & 1980-2013 & $\begin{array}{l}\text { Period of } \\
\text { record }\end{array}$ \\
\hline \multicolumn{10}{|c|}{ Climate region summary (National Climatic Data Center, 2015) } \\
\hline $\begin{array}{l}\text { Climate } \\
\text { Division } 7\end{array}$ & $\begin{array}{l}\text { Southwest } \\
\text { Oklahoma }\end{array}$ & 1895-2015 & 121 & 26.39 & 29.20 & 27.62 & 60.86 & 61.56 & 61.16 \\
\hline 340184 & Altus Dam & 1945-2013 & 62 & 22.42 & 28.74 & 26.84 & 62.55 & 62.04 & 62.31 \\
\hline 342944 & Erick & 1904-2013 & 96 & 22.40 & 25.29 & 24.40 & 60.10 & 60.80 & 60.16 \\
\hline 346035 & Moravia & 1941-2013 & 68 & 22.63 & 26.38 & 25.53 & -- & -- & -- \\
\hline 347952 & Sayre $^{2}$ & 1936-2013 & 77 & 21.35 & 25.59 & 23.98 & 61.60 & -- & 61.14 \\
\hline
\end{tabular}

${ }^{1}$ Period of record may not be continuous.

${ }^{2}$ Station not in aquifer boundary, used for temperature data only.
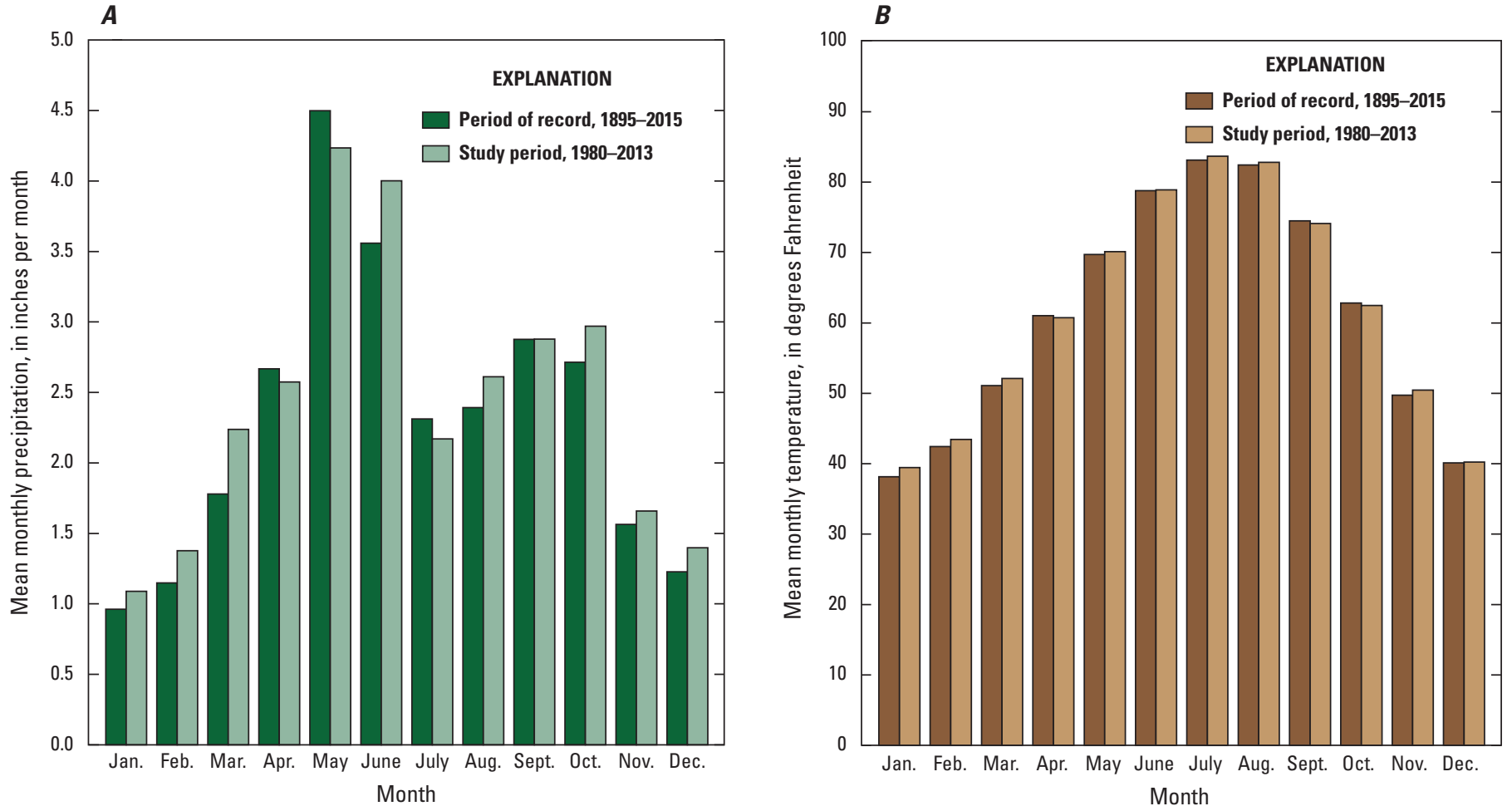

Figure 4. A, Mean monthly precipitation and B, mean monthly temperature, southwest Oklahoma, 1895-2015 and 1980-2013. Data for southwest Oklahoma, Climate Division 7 (National Climatic Data Center, 2015). 


\section{Land Cover}

During the period 2010-15, shrubs/range and crops each covered about a third of the land overlying the North Fork Red River aquifer (Fry and others, 2011; National Agricultural Statistics Service, 2016; fig. 5). Grass/pasture composed most of the remaining third (fig. 5), though scattered wooded (forest) areas and towns (developed areas) including Texola, Erick, Carter, Willow, Snyder, and Mangum also overlie the aquifer. Other towns, including Elk City, Sayre, Lone Wolf, and Granite, which mostly do not overlie the aquifer, draw water from the North Fork Red River aquifer for public supply.

Winter wheat (72.9 percent of cropland by area) was the dominant crop type overlying the North Fork Red River aquifer during the period 2010-15. Cotton (7.7 percent), rye (5.6 percent), alfalfa (3.3 percent), and sorghum (1.7 percent) accounted for at least 1 percent of cropland by area, and other crops, including peanuts (1.1 percent) and barley (1.0 percent), accounted for 4.6 percent of cropland by area (fig. 5). About 4 percent of cropland by area was fallow or idle. Though crop types may change with economic and hydrologic factors, the areal percentages of total crop land cover and individual crop types did not change much over the period 2010-15 (National Agricultural Statistics Service, 2016).

The frost-free growing season is about 200 days and lasts from mid-April to late October (National Agricultural Statistics Service, 2015; Oklahoma Climatological Survey, 2015b). Most crops including corn, cotton, peanuts, sorghum, soybeans, sunflowers, and canola are grown in this season, but winter wheat is planted in the early fall and harvested in June. The length of the growing season and the water requirement for crops in a given year vary with the climate characteristics of that year (Masoner and others, 2003).

\section{Groundwater-Use Characteristics and Trends}

The OWRB permits and regulates groundwater use, with the exception of groundwater use of less than 5 acre-ft/yr for domestic and agricultural purposes and groundwater use for irrigation of less than 3 acres of land. Groundwater-use data for Oklahoma are self-reported annually to the OWRB by permitted users, and the OWRB staff reviewed groundwater-use data described in this report to ensure the quality and completeness of the data. In 2013, 412 long-term temporary and prior-right groundwater-use permits were active for the North Fork Red River aquifer (OWRB, 2015b) (fig. 6). Each permit may include multiple wells that share the allocated groundwater use. Most groundwater-use permits were allocated for irrigation and public supply (fig. 7, table 4). Groundwater-use permits for irrigation were tied to wells and land areas that were relatively evenly distributed across the aquifer; most groundwater-use permits for public supply, in contrast, were tied to wells and land areas concentrated south of Sayre in Beckham County and northeast of Willow in Greer County (fig. 6).

The mean annual reported groundwater use was 15,279 acre-ft/yr for the period of record 1967-2013 and 15,859 acre-ft/yr for the study period 1980-2013 (table 4; Christopher Neel, OWRB, written commun., 2015). The year with the greatest reported groundwater use (26,714 acre-feet [acre-ft]) was 2011. Below-average precipitation and above-average temperatures in that year likely contributed to the increased groundwater use. The year with the least reported groundwater use (9,875 acre-ft) was 1975, and the year with the least reported groundwater use per permit (about 77 acre-ft) was 1997; both 1975 and 1997 were years with above-average precipitation (fig. 3). The groundwater-use period of record 1967-2013 was separated into three smaller periods (1967-85, 1986-97, and 1998-2013) to illustrate trends in the reported groundwater use. The mean annual reported groundwater use decreased from 13,503 to 12,246 acre-ft/yr from the period 1967-85 to the period 1986-97, and then increased from 12,246 to 19,429 acre-ft/yr from the period 1986-97 to the period 1998-2013 (table 4, fig. 7). 


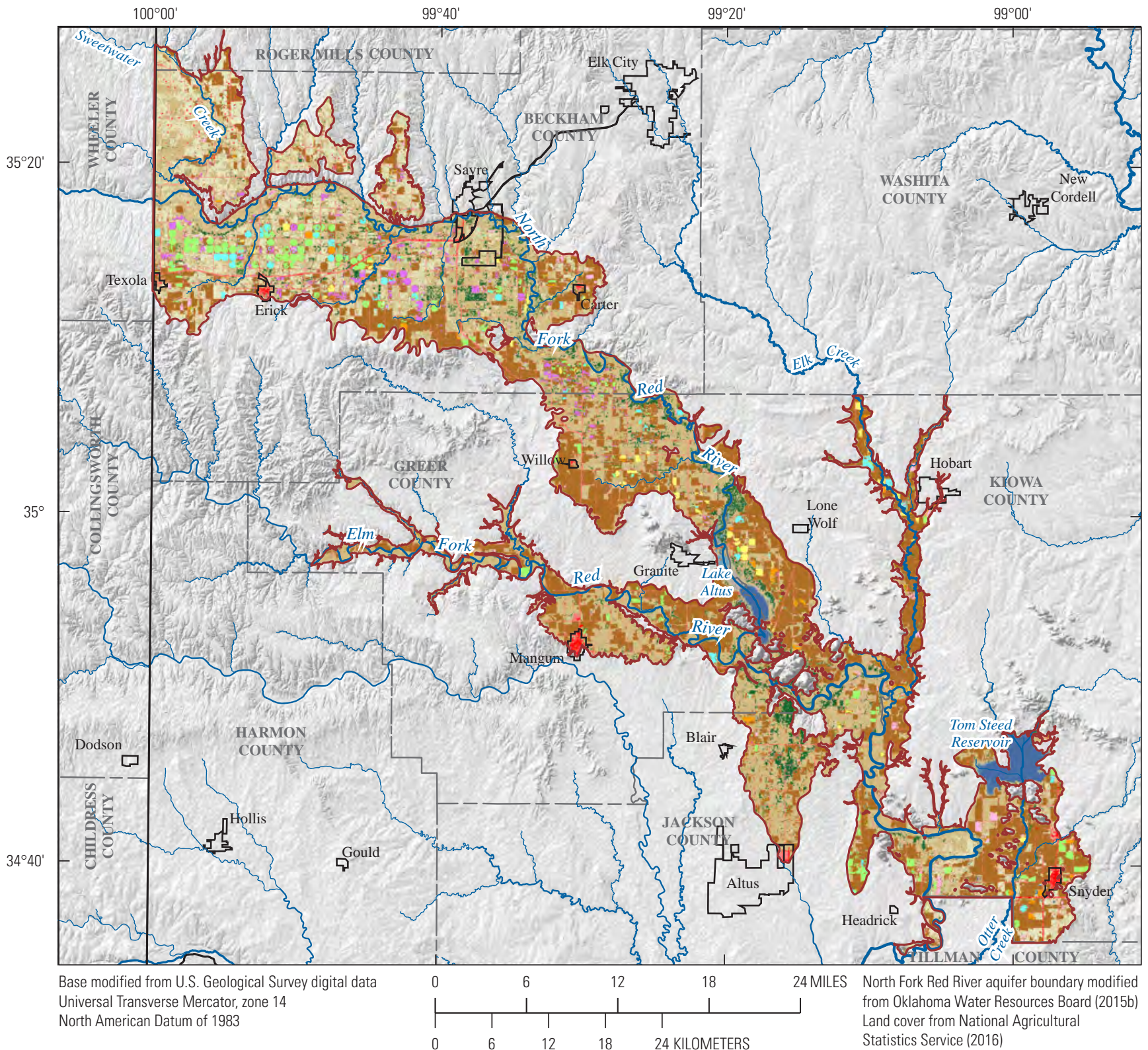

EXPLANATION

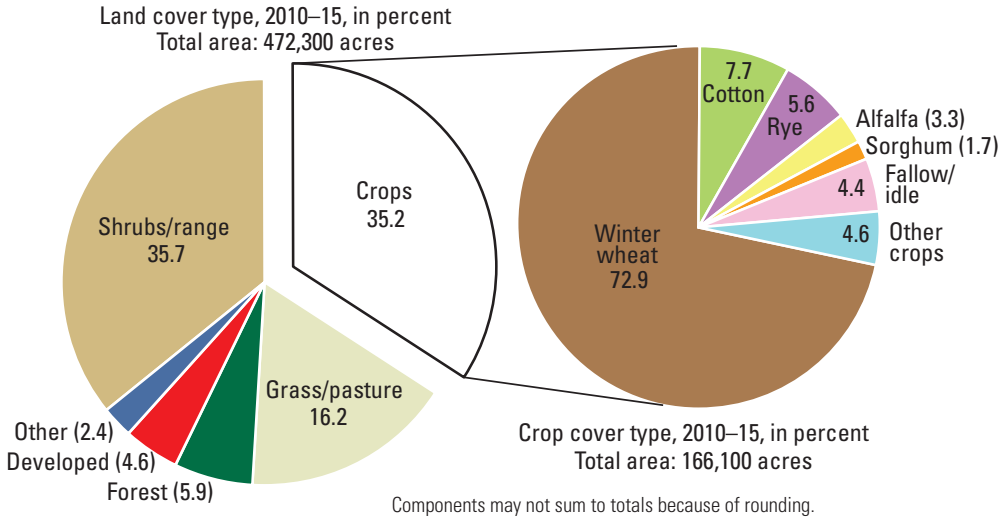

North Fork Red River aquifer boundary

Incorporated area (U.S. Census Bureau, 2000) Land-cover type, 2015

$\square$ Developed

$\square$ Barren

Forest

$\square$ Shrubs/range

Grass/pasture

Other (water, wetland, and barren) Crop cover type

$\begin{array}{ll}\square \text { Winter wheat } & \square \text { Sorghum } \\ \square \text { Cotton } & \square \text { Fallow/idle } \\ \square \text { Rye } & \square \text { Other crops } \\ \square \text { Alfalfa } & \end{array}$

Figure 5. Land and crop cover over the North Fork Red River aquifer, southwest Oklahoma, 2010-15. 


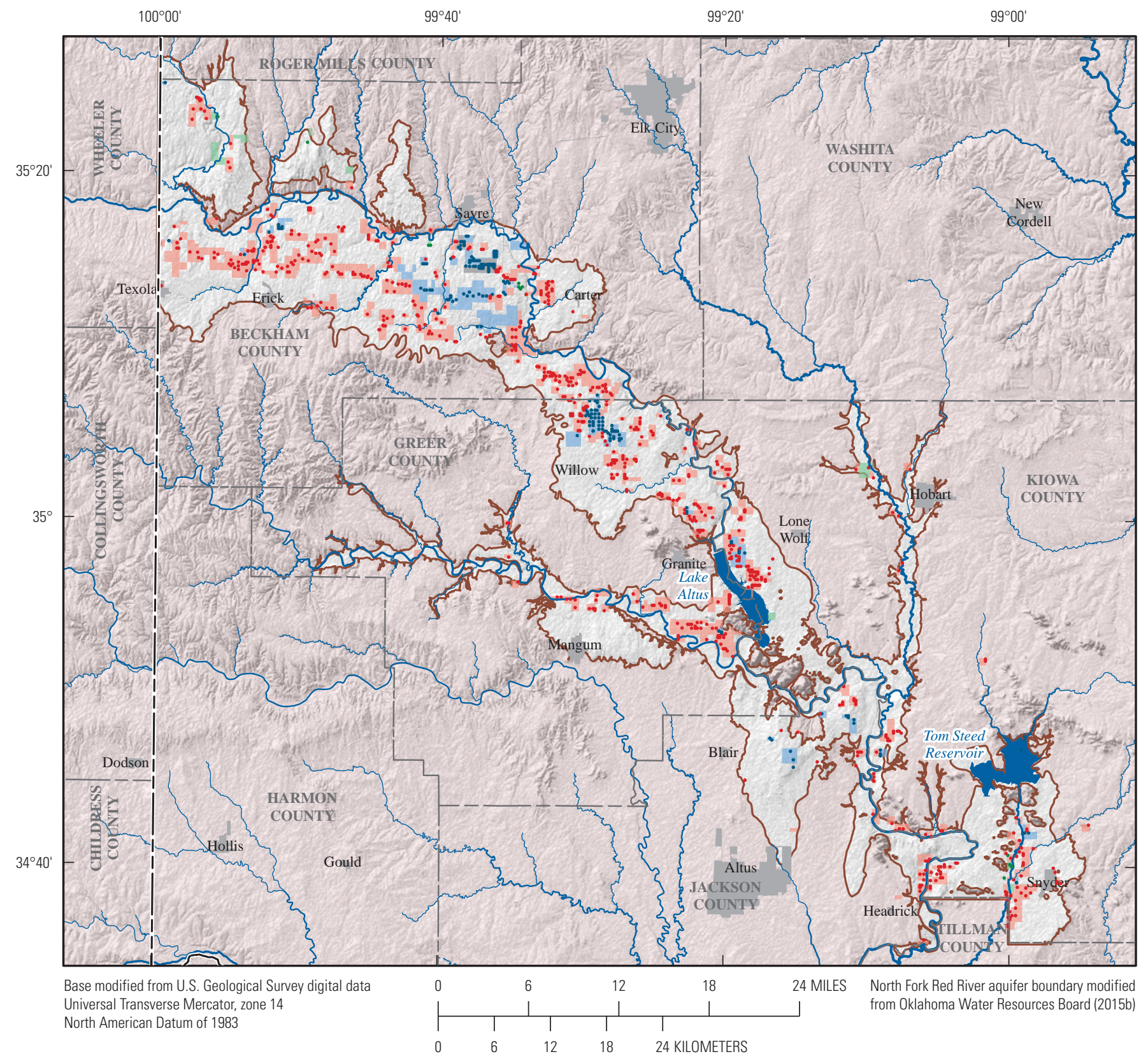

EXPLANATION

Incorporated area (U.S. Census Bureau, 2000)

North Fork Red River aquifer boundary

Allocated groundwater rights (permitted land areas

and permitted wells; Oklahoma Water Resources Board, 2015b)

- Irrigation

- Public Supply

- Other

Figure 6. Land areas and wells permitted for groundwater use from the North Fork Red River aquifer, southwest Oklahoma, 2015. 


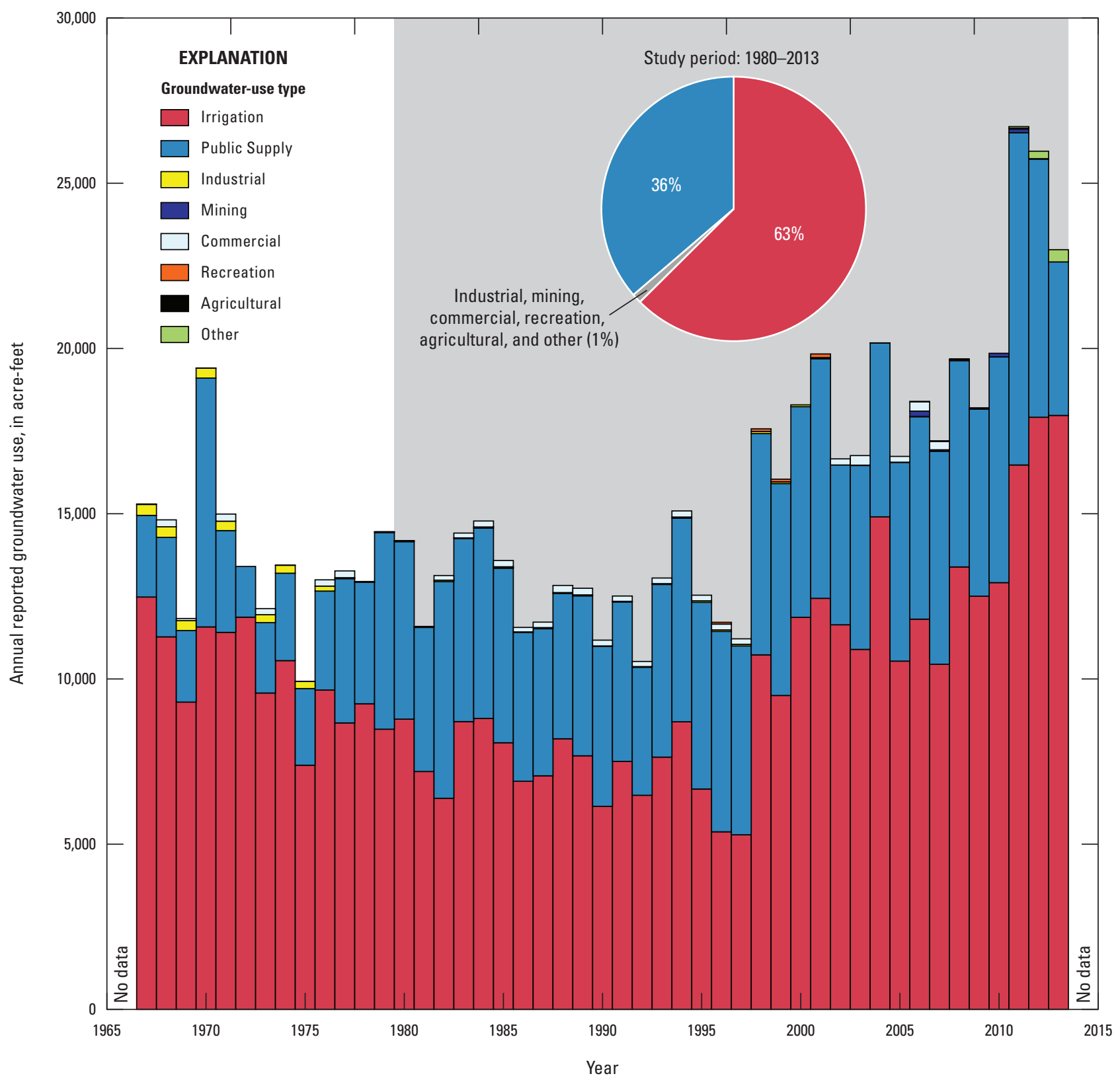

Figure 7. Annual reported groundwater use by type from the North Fork Red River aquifer, 1967-2013. Data from the Oklahoma Water Resources Board water-use database (Christopher Neel, Oklahoma Water Resources Board, written commun., 2015). 
Table 4. Mean annual reported groundwater use by type for the North Fork Red River aquifer, 1967-2013.

[Data from Oklahoma Water Resources Board water-use database (Christopher Neel, Oklahoma Water Resources Board, written commun., 2015); PWS, public water supply; values in parentheses are percentage of total groundwater use]

\begin{tabular}{lccccccccc}
\hline \multirow{2}{*}{ Period } & \multicolumn{7}{c}{ Mean annual reported groundwater use, in acre-feet per year (and percentage), by type ${ }^{1}$} \\
\cline { 2 - 10 } & Irrigation & PWS & Industrial & Mining & Commercial & Recreation & Agriculture & Other & Total \\
\hline 1967-85 & 9,446 & 3,828 & 139 & 0 & 93 & 0 & 0 & 0 & 13,503 \\
& $(70.0)$ & $(28.3)$ & $(1.0)$ & $(0.0)$ & $(0.7)$ & $(0.0)$ & $(0.0)$ & $(0.0)$ & $(100)$ \\
$1986-97$ & 6,993 & 5,046 & 30 & 0 & 172 & 5 & 0 & 0 & 12,246 \\
& $(57.1)$ & $(41.2)$ & $(0.2)$ & $(0.0)$ & $(1.4)$ & $(0.0)$ & $(0.0)$ & $(0.0)$ & $(100)$ \\
$1998-2013$ & 12,872 & 6,389 & 16 & 30 & 74 & 17 & 4 & 41 & 19,429 \\
& $(66.3)$ & $(32.9)$ & $(0.1)$ & $(0.2)$ & $(0.4)$ & $(0.1)$ & $(0.0)$ & $(0.2)$ & $(100)$ \\
Study period, & 9,928 & 5,754 & 24 & 14 & 115 & 10 & 2 & 20 & 15,859 \\
$1980-2013$ & $(62.6)$ & $(36.3)$ & $(0.2)$ & $(0.1)$ & $(0.7)$ & $(0.1)$ & $(0.0)$ & $(0.1)$ & $(100)$ \\
Period of record, & 9,980 & 5,096 & 69 & 10 & 107 & 7 & 1 & 14 & 15,279 \\
$1967-2013$ & $(65.3)$ & $(33.4)$ & $(0.5)$ & $(0.1)$ & $(0.7)$ & $(0.0)$ & $(0.0)$ & $(0.1)$ & $(100)$ \\
\hline
\end{tabular}

${ }^{1}$ Excludes water use of less than 5 acre-feet per year for domestic and agricultural purposes and water use for irrigation of less than 3 acres of land.

Though three of the four greatest individual users of groundwater were municipalities (Elk City, Mangum, and Sayre), irrigation was the major groundwater-use type for the period of record 1967-2013. Irrigation accounted for about 70 percent of reported groundwater use for the period 1967-85, about 57 percent of reported groundwater use for the period 1986-97, and about 66 percent of reported groundwater use for the period 1998-2013 (fig. 7, table 4). Annual irrigation use averaged 9,446 acre- $\mathrm{ft} / \mathrm{yr}$ for the period 1967-85, 6,993 acre-ft/yr for the period 1986-97, and 12,872 acre-ft/yr for the period 1998-2013 (table 4). Reported groundwater use for irrigation notably increased in 1998 and generally continued to increase through 2013 (fig. 7). The number of reporting permits also notably increased in 1998 and continued to increase during the period 19982013. These increases in reported groundwater use and the number of reporting permits likely resulted from decreased precipitation in 1998 as compared to the 3 previous years.
Sustained increases in reported groundwater use for the period 1998-2013 also coincided with and may be related to a period of above-average annual mean temperature (1996-2015, fig. 3B). Most of the increase in reported groundwater use for the period 1998-2013 was for irrigation in Beckham County which increased from about 30 to 50 percent of reported groundwater use in that period (fig. 8).

Yields of wells completed in the North Fork Red River aquifer vary with location and depth. Well yields reported for irrigation, public-supply, and domestic plus non-irrigation agricultural use were mostly 100-450, 150-250, and 10-25 gallons per minute (gal/min), respectively (OWRB, 2015b; USGS, 2015a; table 5, fig. 9). Irrigation and publicsupply wells with the greatest reported yields (greater than or equal to $800 \mathrm{gal} / \mathrm{min}$ ) generally were located in west-central Beckham County north of Erick, Okla., and near Lake Altus east of Granite, Okla. Wells with the greatest reported yields generally were greater than 150 feet (ft) in depth. 


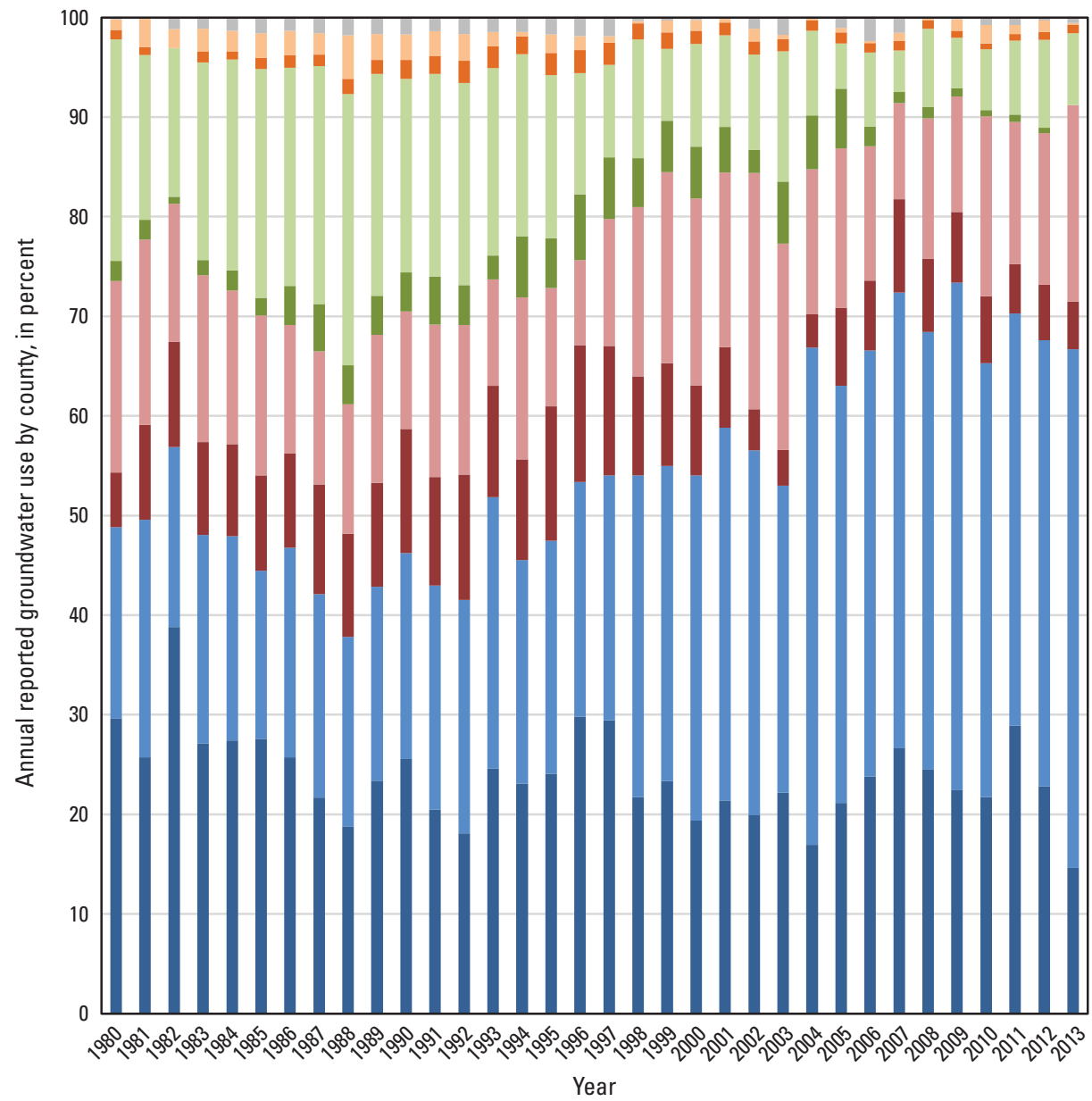

EXPLANATION

- Beckham County, public supply

Beckham County, irrigation

- Greer County, public supply

- Greer County, irrigation

Kiowa County, public supply

Kiowa County, irrigation

- Jackson County, public supply

Jackson County, irrigation

Other

Figure 8. Annual reported groundwater use by county from the North Fork Red River aquifer, 1980-2013. Data from the Oklahoma Water Resources Board water-use database (Christopher Neel, Oklahoma Water Resources Board, written commun., 2015).

Table 5. Statistical summary of reported yields of wells completed in the North Fork Red River aquifer, 1936-2015.

[Data compiled from the Oklahoma Water Resources Board (2015b) and U.S. Geological Survey (2015a)]

\begin{tabular}{|c|c|c|c|c|c|c|c|}
\hline \multirow[b]{2}{*}{ Water-use type } & \multirow{2}{*}{$\begin{array}{l}\text { Number of wells } \\
\text { with reported } \\
\text { yield values }\end{array}$} & \multicolumn{6}{|c|}{ Statistics for reported well-yield values, in gallons per minute ${ }^{1}$} \\
\hline & & Minimum & $\begin{array}{c}\text { 25th } \\
\text { percentile }\end{array}$ & Median & $\begin{array}{c}\text { 75th } \\
\text { percentile }\end{array}$ & Maximum & Mean \\
\hline Irrigation & 500 & 15 & 100 & 250 & 450 & 1,500 & 333 \\
\hline Public supply & 126 & 15 & 150 & 198 & 250 & 900 & 215 \\
\hline Industrial and mining & 55 & 5 & 35 & 60 & 70 & 1,200 & 94 \\
\hline $\begin{array}{l}\text { Domestic and agriculture } \\
\text { (non-irrigation) }\end{array}$ & 682 & 1 & 10 & 15 & 25 & 300 & 25 \\
\hline
\end{tabular}

${ }^{1}$ Well-yield values less than 1 gallon per minute were excluded. 


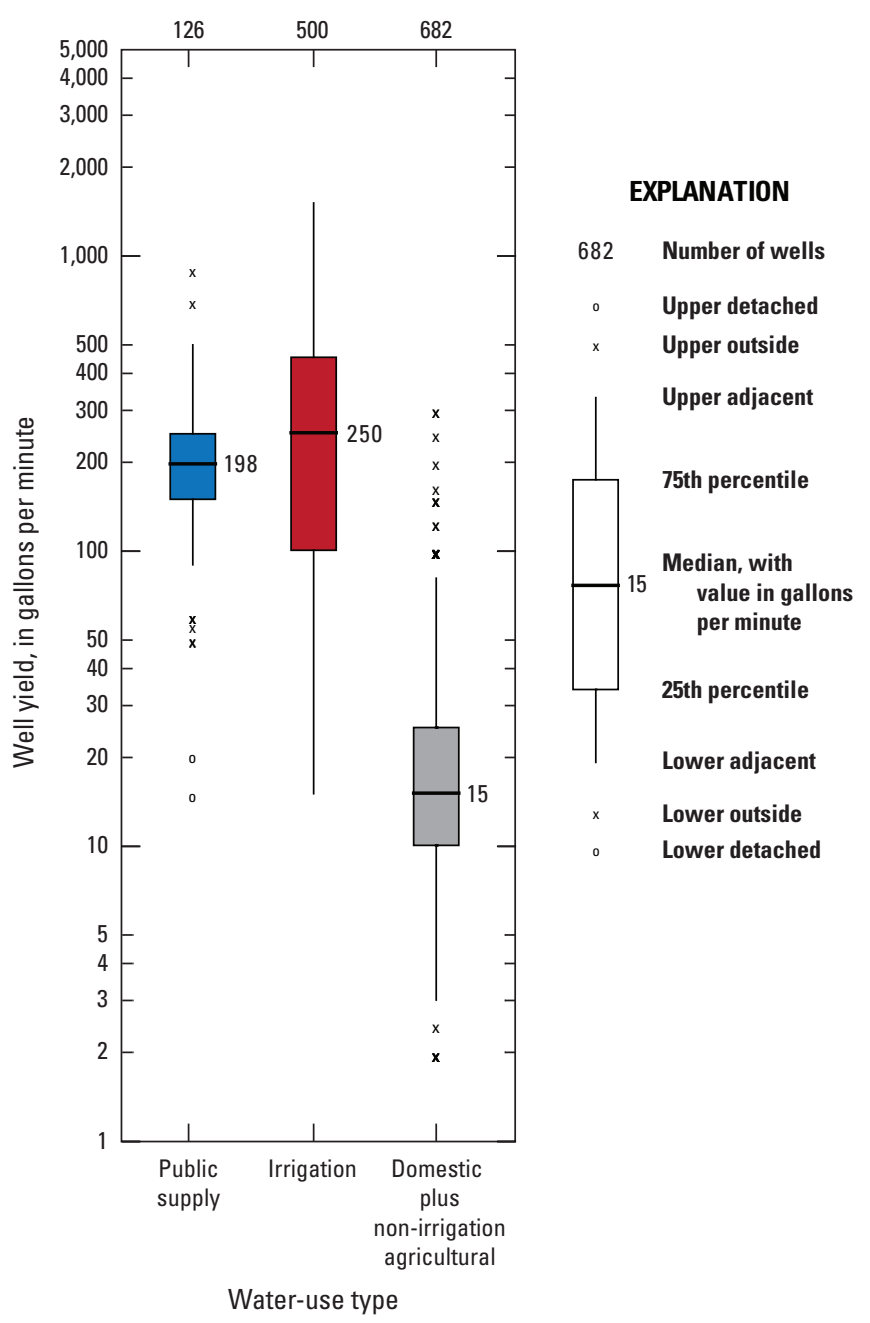

Figure 9. Statistics for reported yields of wells completed in the North Fork Red River aquifer. Data compiled from the Oklahoma Water Resources Board (2015b) and the U.S. Geological Survey (2015a).

\section{Streamflow Characteristics and Trends}

According to data collected at the Carter streamgage (07301500), the North Fork Red River upstream from Lake Altus has become increasingly dependent on base flow since the beginning of the period of record in the late 1930s (Smith and Wahl, 2003; Esralew and Lewis, 2010). Though annual precipitation in west central Oklahoma (climate division 4; National Climatic Data Center, 2015) significantly increased over the streamgage period of record, no trends in annual streamflow were apparent at the Carter streamgage (07301500). Annual peak streamflow and annual number of zero-flow days at this streamgage significantly decreased over the period of record while annual base flow and annual base-flow index significantly increased over the period of record (Esralew and Lewis, 2010). The causes of these trends in annual streamflow statistics are not clear. Increasing trends in base flow could be related to changes in irrigation practices that may promote artificial recharge of applied water and contribute additional base flow to streams. Another possible cause of these trends in streamflow statistics is the construction of impoundments (Kennon, 1966) in the North Fork Red River watershed. Though no large impoundments overlie the North Fork Red River aquifer upstream from the Carter streamgage (07301500), several floodwater-retarding structures were constructed on the North Fork Red River tributaries Timber Creek (in the early 1960s) and McClellan Creek (in the 1980s) (U.S. Army Corps of Engineers, 2015a) (fig. 2). Floodwater-retarding structures were designed to impound runoff and slowly release it downstream; therefore, these structures could contribute to the decreasing trends in annual peak streamflow and annual number of zero-flow days as well as the increasing trends in annual base flow and annual base-flow index. Whatever the cause, these trends in annual streamflow statistics are important considerations for water resources planning for irrigation and public-supply surfacewater use at Lake Altus.

\section{Groundwater Quality}

The groundwater quality in some parts of the North Fork Red River aquifer may limit groundwater use for some purposes. Groundwater-quality data for the North Fork Red River aquifer were collected between July 28, 2014, and August 13, 2014, as part of the OWRB Groundwater Monitoring and Assessment Program (OWRB, 2015c). Groundwater was sampled from 20 wells; 14 were in Beckham County, 5 were in Greer County, and 1 was in Kiowa County (fig. 10). The groundwater samples were analyzed for selected parameters including physical properties (specific conductance, temperature, and $\mathrm{pH}$ ), major ions, nutrients, and trace metals (table 6). Total dissolved solids (TDS) concentrations of groundwater ranged from 295 to 3,520 milligrams per liter $(\mathrm{mg} / \mathrm{L})$ with a mean concentration of $895 \mathrm{mg} / \mathrm{L}$ and a median concentration of $543 \mathrm{mg} / \mathrm{L}$ (table 6). The U.S. Environmental Protection Agency (2017) has established a secondary drinking-water standard of $500 \mathrm{mg} / \mathrm{L}$ for TDS, but the State of Oklahoma designates a domestic beneficial use for groundwater with TDS concentrations below 3,000 mg/L (OWRB, 2015c). Specific conductance values ranged from 508 to 4,830 microsiemens per centimeter at 25 degrees Celsius $\left(\mu \mathrm{S} / \mathrm{cm}\right.$ at $\left.25{ }^{\circ} \mathrm{C}\right)$ with a mean value of $1,340 \mu \mathrm{S} / \mathrm{cm}$ and a median value of $862 \mu \mathrm{S} / \mathrm{cm}$. All groundwater samples from the North Fork Red River aquifer were classified as hard (hardness concentration exceeded $180 \mathrm{mg} / \mathrm{L}$ ). Nitrate plus nitrite was the only parameter with measured concentrations exceeding a U.S. Environmental Protection Agency (2017) primary drinking-water standard (10 mg/L). Nitrate plus nitrite concentrations exceeded this standard in six samples; the maximum measured nitrate plus nitrite concentration was $19.4 \mathrm{mg} / \mathrm{L}$, the median was $7.95 \mathrm{mg} / \mathrm{L}$, and the 75th percentile was $10.73 \mathrm{mg} / \mathrm{L}$. 


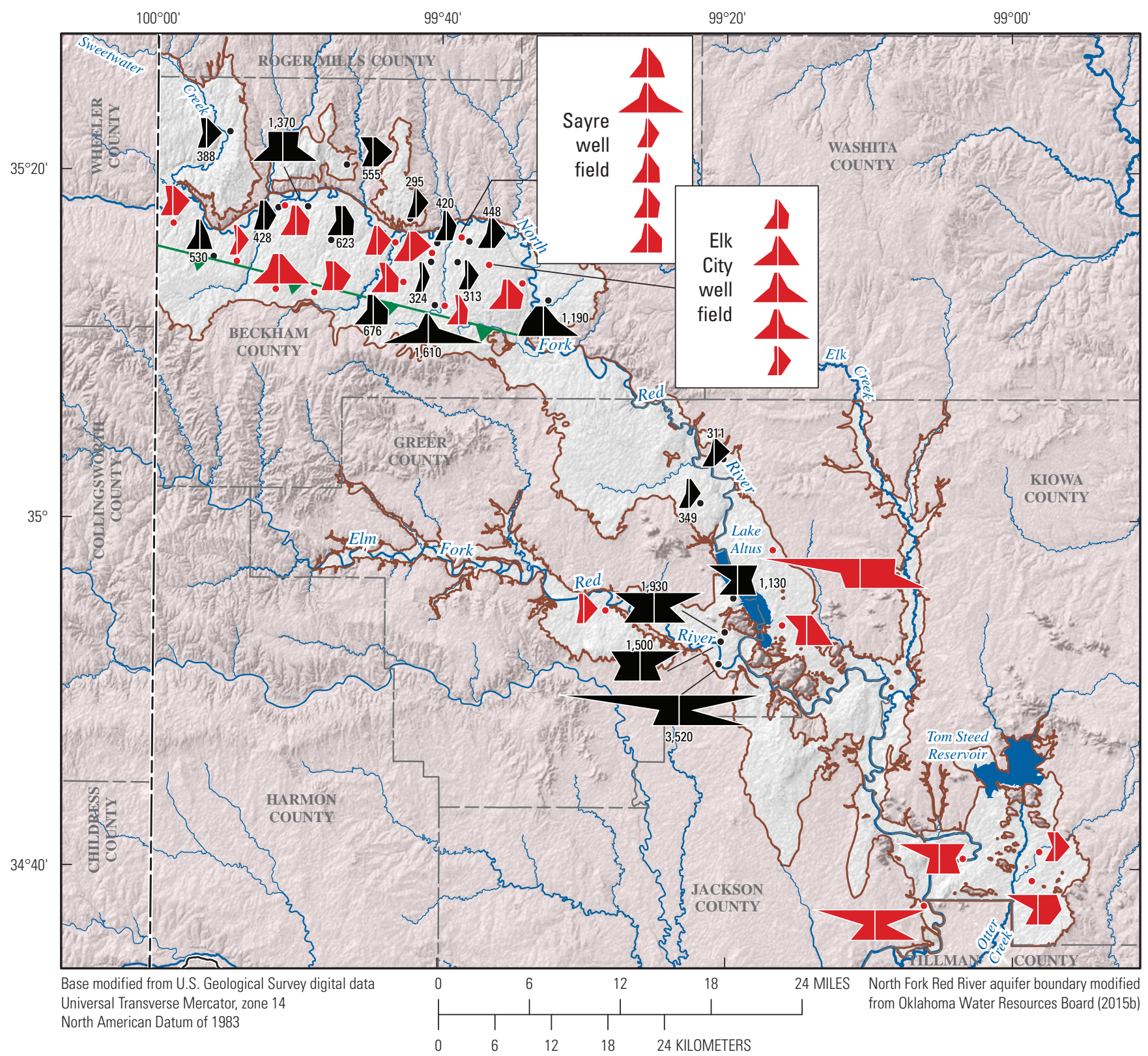

EXPLANATION
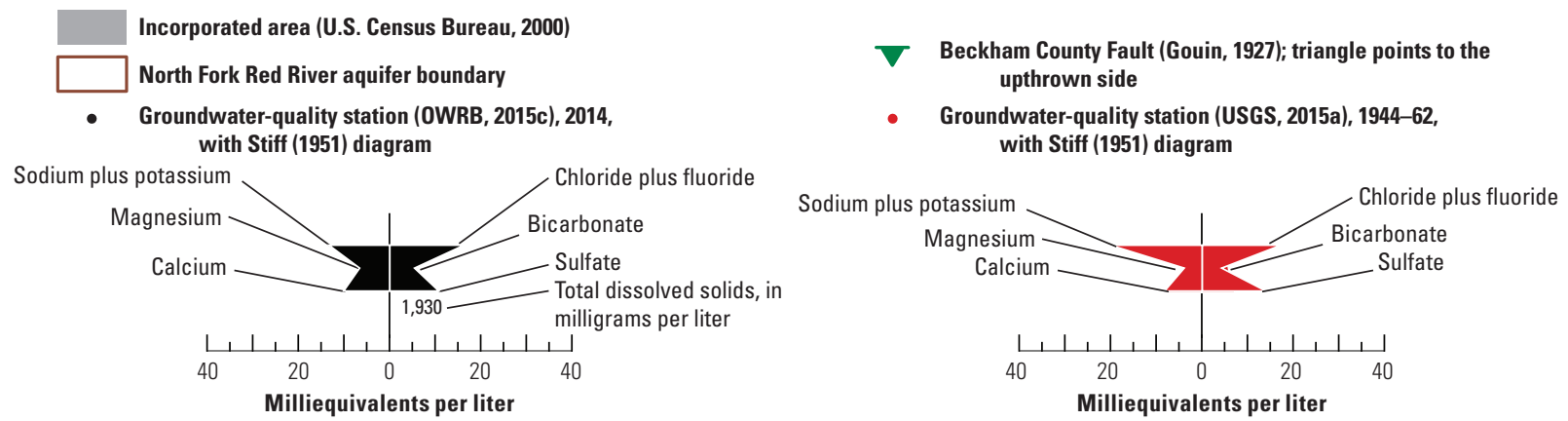

Figure 10. Groundwater-quality stations in the North Fork Red River aquifer, southwest Oklahoma, 1944-62 and July-August 2014. 
Table 6. Statistical summary of groundwater-quality data from 20 wells completed in the North Fork Red River aquifer, JulyAugust 2014.

[All data are from OWRB (2015c). $\mu \mathrm{S} / \mathrm{cm}$ at $25^{\circ} \mathrm{C}$, microsiemens per centimeter at 25 degrees Celsius; ${ }^{\circ} \mathrm{C}$, degrees Celsius; CaCO ${ }_{3}$, calcium carbonate; mg/L, milligrams per liter; <, less than analytical detection limit; $\mu \mathrm{g} / \mathrm{L}$, micrograms per liter; --, not calculated because more than 10 analyses were below analytical detection limit; +, includes samples with different analytical detection limits]

\begin{tabular}{|c|c|c|c|c|c|c|c|c|}
\hline \multirow{2}{*}{$\begin{array}{l}\text { Water-quality } \\
\text { constituent }\end{array}$} & \multirow{2}{*}{$\begin{array}{c}\text { Units of } \\
\text { measurement }\end{array}$} & \multirow{2}{*}{$\begin{array}{l}\text { Number of } \\
\text { samples } \\
\text { less than } \\
\text { detection } \\
\text { limit }\end{array}$} & \multirow{2}{*}{$\begin{array}{c}\text { Mean of } \\
\text { detections }\end{array}$} & \multirow{2}{*}{ Minimum } & \multicolumn{3}{|c|}{ Percentile } & \multirow{2}{*}{ Maximum } \\
\hline & & & & & 25 & 50 & 75 & \\
\hline Specific conductance & $\mu \mathrm{S} / \mathrm{cm}$ at $25^{\circ} \mathrm{C}$ & 0 & 1,340 & 508 & 631 & 862 & 1,840 & 4,830 \\
\hline Temperature & ${ }^{\circ} \mathrm{C}$ & 0 & 21.5 & 18.9 & 20.1 & 21.1 & 22.2 & 30.6 \\
\hline Alkalinity (as $\mathrm{CaCO}_{3}$ ) & $\mathrm{mg} / \mathrm{L}$ & 0 & 225 & 134 & 199 & 232 & 252 & 331 \\
\hline Total dissolved solids & $\mathrm{mg} / \mathrm{L}$ & 0 & 895 & 295 & 379 & 543 & 1,230 & 3,520 \\
\hline Hardness & $\mathrm{mg} / \mathrm{L}$ & 0 & 487 & 187 & 265 & 342 & 794 & 1,180 \\
\hline Calcium & $\mathrm{mg} / \mathrm{L}$ & 1 & 121 & 53.2 & 71.8 & 94.9 & 172 & 312 \\
\hline Potassium & $\mathrm{mg} / \mathrm{L}$ & 2 & 2.56 & $<0.5$ & 1.5 & 2.1 & 3.2 & 9.3 \\
\hline Bicarbonate & $\mathrm{mg} / \mathrm{L}$ & 0 & 277 & 165 & 244 & 286 & 310 & 408 \\
\hline Sulfate & $\mathrm{mg} / \mathrm{L}$ & 2 & 268 & $<10$ & 38.4 & 142 & 383 & 1,090 \\
\hline Chloride & $\mathrm{mg} / \mathrm{L}$ & 5 & 138 & $<10$ & 11.6 & 24.8 & 79.8 & 981 \\
\hline Fluoride & $\mathrm{mg} / \mathrm{L}$ & 8 & 0.295 & $<0.2$ & $<0.2$ & 0.28 & 0.42 & 0.74 \\
\hline Bromide & $\mu \mathrm{g} / \mathrm{L}$ & 1 & 593 & $<100$ & 265 & 329 & 613 & 1,960 \\
\hline Silica & $\mathrm{mg} / \mathrm{L}$ & 0 & 23.2 & 9.95 & 13.9 & 24.9 & 27.4 & 43.7 \\
\hline $\begin{array}{l}\text { Nitrate plus nitrate (as } \\
\text { nitrogen) }\end{array}$ & $\mathrm{mg} / \mathrm{L}$ & 0 & 8.29 & 0.83 & 5.58 & 7.95 & 10.73 & 19.4 \\
\hline Boron+ & $\mu \mathrm{g} / \mathrm{L}$ & 1 & 193 & $<20$ & 57.2 & 97.6 & 178 & 1,460 \\
\hline Cadmium & $\mu g / L$ & 20 & -- & $<5$ & $<5$ & $<5$ & $<5$ & $<5$ \\
\hline Chromium & $\mu g / L$ & 20 & -- & $<5$ & $<5$ & $<5$ & $<5$ & $<5$ \\
\hline Copper & $\mu g / L$ & 17 & -- & $<5$ & $<5$ & $<5$ & $<5$ & 51.7 \\
\hline Iron+ & $\mu g / L$ & 19 & -- & $<50$ & $<50$ & $<50$ & $<50$ & 32.9 \\
\hline Lead+ & $\mu g / L$ & 20 & -- & $<10$ & $<10$ & $<10$ & $<10$ & $<10$ \\
\hline Manganese+ & $\mu g / L$ & 15 & -- & $<5.0$ & $<5.0$ & $<5.0$ & 5.5 & 7.6 \\
\hline Molybdenum+ & $\mu \mathrm{g} / \mathrm{L}$ & 19 & -- & $<5.0$ & $<5.0$ & $<5.0$ & $<5.0$ & 12.8 \\
\hline Uranium & $\mu \mathrm{g} / \mathrm{L}$ & 5 & 4.1 & $<1$ & 1.6 & 3.4 & 5.1 & 12.9 \\
\hline Vanadium+ & $\mu \mathrm{g} / \mathrm{L}$ & 6 & 9.8 & $<5.0$ & $<5.0$ & 7.9 & 14.2 & 29.3 \\
\hline Zinc+ & $\mu \mathrm{g} / \mathrm{L}$ & 12 & -- & $<5.0$ & $<5.0$ & 4.3 & 16.2 & 91.7 \\
\hline
\end{tabular}


The 2014 OWRB major-ion groundwater-quality data for each site were graphed on Stiff (1951) diagrams and mapped on figure 10. Historical (1944-62) Stiff diagrams showing available groundwater-quality data from the USGS National Water Information System (NWIS) database (USGS, 2015a) were added to figure 10 for visual comparison. The 2014 samples from Beckham County mostly were below the mean and median TDS values, indicating relatively fresh groundwater in those areas that may have lower groundwater residence times, possibly near zones of greater recharge. Stiff diagram distribution for these sites displayed low sodium, potassium, magnesium, chloride, and sulfate levels, with small spikes in calcium and bicarbonate, possibly derived from the dissolution of calcium-carbonate caliche. Three samples from Beckham County had greater TDS, calcium, and sulfate signatures, likely caused by dissolution of gypsum from the Cloud Chief or Blaine Formations (fig. 11). Of the six 2014 samples from Greer and Kiowa Counties, four had greater than average TDS concentrations and had high concentrations of sodium, chloride, calcium, and sulfate. These four sites are near the confluence of the Elm Fork Red River and the North Fork Red River. These increased constituent concentrations likely were from dissolution of halite and gypsum beds of the Blaine Formation of Permian age, which is exposed in the headwaters of the Elm Fork Red River watershed (figs. 11-12).
Major-ion groundwater-quality data (OWRB, 2015c; USGS, 2015a) were graphed on a Piper (1944) diagram (fig. 13) for visualization of groundwater types and mixing trends between groundwater of the North Fork Red River aquifer and the adjacent Permian bedrock. Groundwater samples from Permian bedrock units showed a downgradient transition from calcium- and sulfate-dominated water (in the Rush Springs Sandstone and Dog Creek Shale) to sodiumand chloride-dominated water (in the Flowerpot Shale and Hennessey Group). Groundwater samples from the North Fork Red River aquifer showed a similar pattern when grouped by county (fig. 13). Calcium was the dominant cation and bicarbonate was the dominant anion in most of the groundwater samples from the North Fork Red River aquifer, especially those from Beckham County (fig. 13). In some samples from Beckham County, however, sulfate was the dominant anion, which may indicate influence from gypsum-rich units in the underlying Permian bedrock. In most downgradient samples from the North Fork Red River aquifer (in Greer, Kiowa, and Jackson Counties), sodium was the dominant cation, and chloride or sulfate was the dominant anion. These groundwater samples were characteristic of samples from the Flowerpot Shale and Hennessey Group of Permian age (figs. 11-13). 


\begin{tabular}{|c|c|c|c|c|c|}
\hline System & \multicolumn{2}{|c|}{ Geologic Unit } & $\begin{array}{l}\text { Hydrogeologic } \\
\text { Unit }\end{array}$ & \begin{tabular}{|c|} 
Thickness, \\
in feet
\end{tabular} & Description \\
\hline Quaternary & \multicolumn{2}{|c|}{$\begin{array}{l}\text { Alluvium and terrace } \\
\text { deposits (with colluvium } \\
\text { and dune deposits) }\end{array}$} & $\begin{array}{l}\text { North Fork Red } \\
\text { River aquifer }\end{array}$ & $0-250$ & $\begin{array}{l}\text { Silt, sand, and clay deposited by North Fork and } \\
\text { tributaries often reworked by wind; occasionally } \\
\text { containing quartzitic gravel and slightly cemented } \\
\text { by calcium carbonate. }\end{array}$ \\
\hline Tertiary & \multicolumn{2}{|c|}{ Ogallala Formation } & $\begin{array}{l}\text { High Plains } \\
\text { (Ogallala) } \\
\text { aquifer }\end{array}$ & $0-600$ & $\begin{array}{l}\text { Brown to light tan to salmon, mostly unconsolidated } \\
\text { clay, silt, sand, and gravel with zones of caliche near } \\
\text { the surface. }\end{array}$ \\
\hline \multirow{10}{*}{ Permian } & \multirow{2}{*}{ 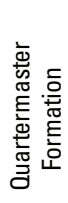 } & $\begin{array}{l}\text { Elk City } \\
\text { Sandstone }\end{array}$ & Elk City aquifer & \multirow{2}{*}{$0-400$} & $\begin{array}{l}\text { Reddish-brown, fine-grained sandstone with silt and } \\
\text { clay, weakly cemented by iron oxide, calcium } \\
\text { carbonate, and gypsum. }\end{array}$ \\
\hline & & Doxey Shale & & & Reddish-brown, silty shale and siltstone. \\
\hline & \multicolumn{2}{|c|}{ Cloud Chief Formation } & & $0-400$ & $\begin{array}{l}\text { Reddish-brown to orange-brown shale interbedded } \\
\text { with siltstone and sandstone; some dolomite and } \\
\text { much gypsum near base. }\end{array}$ \\
\hline & \multirow{2}{*}{ 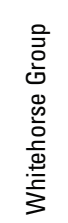 } & $\begin{array}{l}\text { Rush Springs } \\
\text { Formation }\end{array}$ & $\begin{array}{l}\text { Western } \\
\text { Oklahoma } \\
\text { minor aquifer }\end{array}$ & \multirow{2}{*}{$0-390$} & $\begin{array}{l}\text { Red to pink, massive, fine-grained, gypsiferous } \\
\text { sandstone. }\end{array}$ \\
\hline & & $\begin{array}{l}\text { Marlow } \\
\text { Formation }\end{array}$ & & & $\begin{array}{l}\text { Orange-brown, fine-grained sandstone and siltstone } \\
\text { with some dolomite and gypsum. }\end{array}$ \\
\hline & \multirow{4}{*}{ 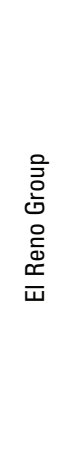 } & Dog Creek Shale & & $0-80$ & $\begin{array}{l}\text { Red, brown, and green gypsiferous shales with several } \\
\text { beds of siltstone, sandstone, and dolomite. }\end{array}$ \\
\hline & & Blaine Formation & & $0-140$ & $\begin{array}{l}\text { Beds of white massive gypsum and thin beds of gray } \\
\text { medium-grained dolomite or dolomitic limestone } \\
\text { separated by well-defined units of red and green shale. }\end{array}$ \\
\hline & & Flowerpot Shale & & $0-150$ & $\begin{array}{l}\text { Red, brown, and maroon blocky shales with green and } \\
\text { gray shales and thin beds of gypsum and dolomite; } \\
\text { Satin-spar gypsum occurs throughout. }\end{array}$ \\
\hline & & $\begin{array}{l}\text { Duncan (San } \\
\text { Angelo) } \\
\text { Sandstone }\end{array}$ & & $0-40$ & $\begin{array}{l}\text { Grayish-brown to buff, indurated, highly cross-bedded, } \\
\text { ripple-marked, nonfossiliferous, silty to very fine-grained } \\
\text { dolomitic sandstone with interbedded shale. }\end{array}$ \\
\hline & \multicolumn{2}{|c|}{ Hennessey Group } & & $0-500$ & $\begin{array}{l}\text { Yellowish gray to buff unfossiliferous shale with } \\
\text { calcareous fine-grained siltstone. }\end{array}$ \\
\hline Cambrian & \multicolumn{2}{|c|}{ Wichita Granite Group } & & & Igneous rocks of Wichita Uplift. \\
\hline
\end{tabular}

Modified from Smith and Wahl, 2003

Figure 11. Stratigraphic chart showing surficial geologic and hydrogeologic units of the North Fork Red River aquifer study area, southwest Oklahoma. 


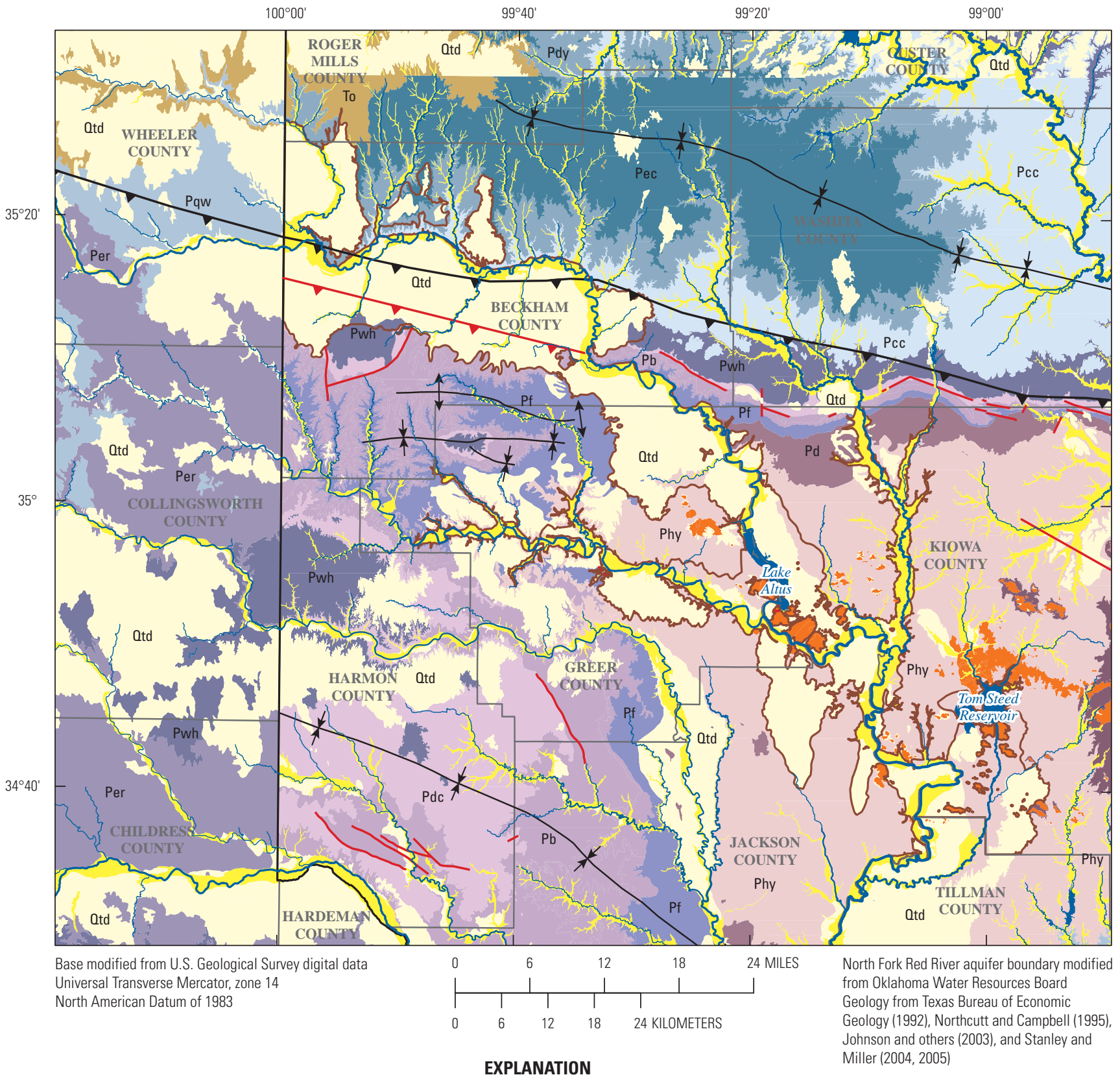

Surficial geologic unit Quaternary

Active alluvium (Oal)

Terrace (0td), including dunes and colluvium

\section{Tertiary}

Ogallala Formation (To)

Permian

Elk City Sandstone (Pec)

Doxey Formation (Pdy)

Quartermaster Formation and Whitehorse Group, undivided (Pqw, in Texas)

Cloud Chief Formation (Pcc)

\section{EXPLANATION}




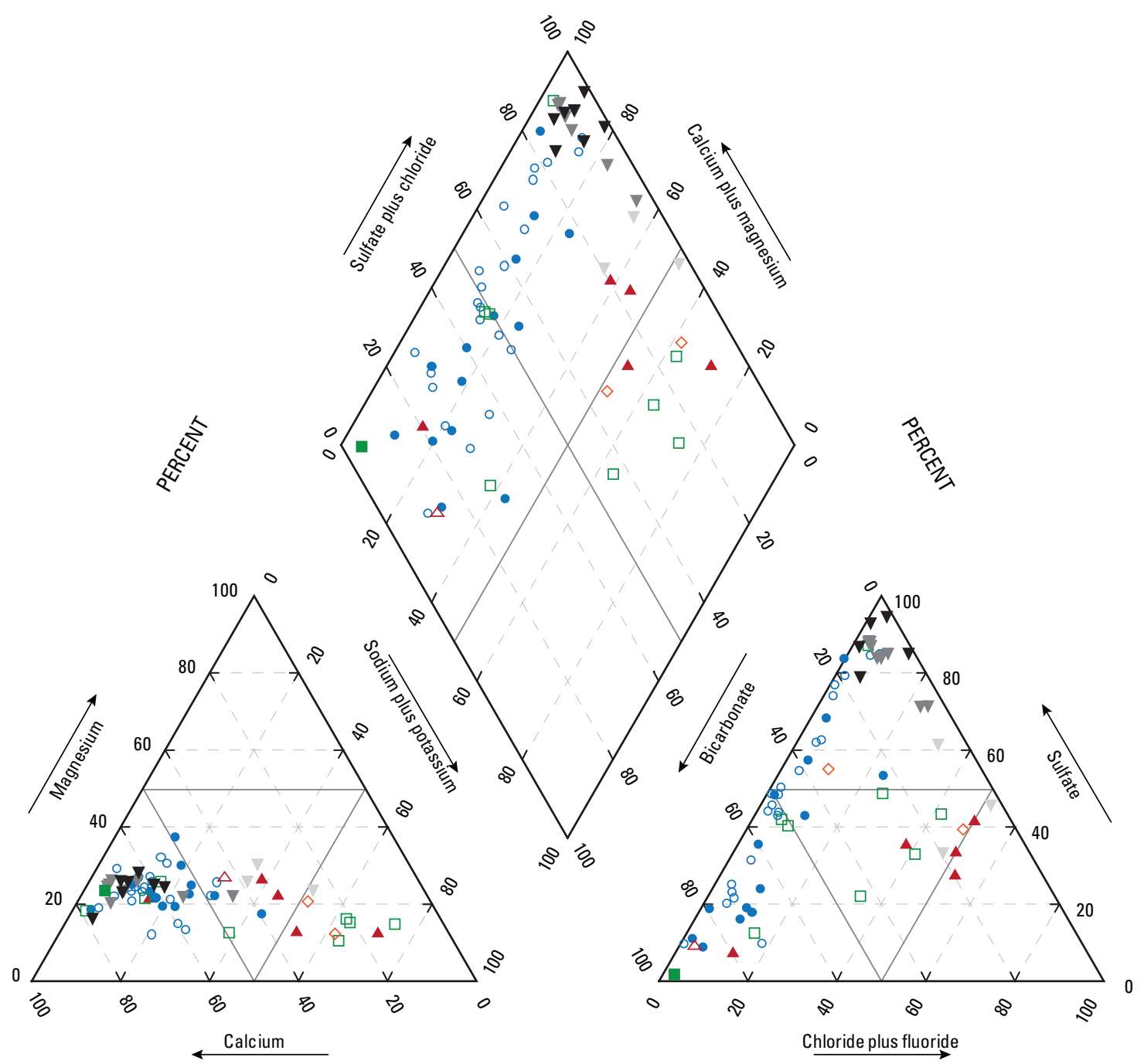

PERCENT

Plot based on Piper (1944) Sample locations shown on figure 10

EXPLANATION

Groundwater-quality sample of water produced from the North Fork Red River aquifer, 2014 (Oklahoma Water Resources Board, 2015c)

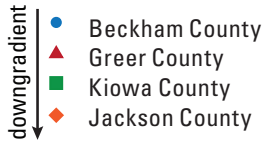

Groundwater-quality sample of water produced from the Permian-age bedrock units adjacent to the North Fork Red River aquifer, 1944-61 (U.S. Geological Survey, 2015a)

Rush Springs Formation (Whitehorse Group) and Dog Creek Shale

Blaine Formation

Flowerpot Shale and Hennessey Group

Figure 13. Piper diagram showing groundwater-quality samples of water produced from the North Fork Red River aquifer, 1944-62 and July-August 2014. 


\section{Hydrogeology of the North Fork Red River Aquifer}

In northern Beckham County, the North Fork Red River parallels the Mountain View Fault Zone (fig. 12), which was most active in the late Paleozoic but has been relatively dormant in recent geologic time (Johnson, 1989). The Mountain View Fault Zone separates the Wichita Uplift and the southern limb of the Anadarko Basin, a broad syncline with an axis trending west-northwest to east-southeast (fig. 12). In southeastern Beckham County, the North Fork Red River turns south and then southwest as it traverses the Wichita Uplift (fig. 12). The Paleozoic sedimentary rocks of the Anadarko Basin can be tens of thousands of feet thick. The Paleozoic sedimentary rocks of the Wichita Uplift are only hundreds to thousands of feet thick and are not present where igneous rocks outcrop.

\section{Quaternary Alluvium and Terrace}

The Quaternary alluvium and terrace deposits (figs. 11-12) that compose the North Fork Red River aquifer were transported primarily by water and range from clay to gravel in size. The terrace material includes windblown deposits (Burton, 1965) that form dunes as high as $30 \mathrm{ft}$ in the adjacent deposits of the Tillman Terrace aquifer (Barclay and Burton, 1953). Narrow rings of boulder-size gravel formed adjacent to the slopes of granitic mountains and coalesced with terrace deposits, but these colluvial (talus) deposits are a minor component of the aquifer in terms of geographic extent (Stanley and Miller, 2004). Discontinuous and poorly sorted layers of clay, silt, sand, and gravel generally become coarser with depth in the alluvium and terrace deposits, and quartzite gravels often occur near the contact with underlying bedrock (Barclay and Burton, 1953; Merritt, 1958; Burton, 1965; Hollowell, 1965a, b). Zones of calcium-carbonate caliche are common in the aquifer, especially near the land surface in Beckham County (Burton, 1965).

\section{Bedrock Units}

\section{Tertiary Ogallala Formation}

Strata of the Ogallala Formation outcrop in the far northwest part of the study area (figs. 11-12). The Ogallala Formation is composed of gravel, sand, silt, and clay sediments loosely held together by calcium carbonate cement which locally forms layers of caliche (Belden and Osborn, 2002). These sediments were eroded from the ancestral Rocky Mountains and were deposited in alluvial fans that coalesced to form a large piedmont (Gutentag and others, 1984). Strata of the Ogallala Formation may underlie the Quaternary alluvium and terrace deposits north of the North Fork Red River in the vicinity of Sweetwater Creek in northwest
Beckham County. The extent of subcrop areas of the Ogallala Formation is not well defined because the loosely consolidated materials of the Ogallala Formation, especially as found in drill cuttings, resemble those of the overlying alluvium and terrace deposits.

\section{Permian Bedrock Units}

Mesozoic sedimentary rocks are absent, and Paleozoic (Permian) bedrock units underlie most of the Quaternary alluvium and terrace deposits in the study area (figs. 11-12). The Permian bedrock units (often referred to as red beds) generally are fine grained and are composed of red to orangebrown shale, siltstone, and fine sandstone interbedded with dolomite and gypsum (Stanley and Miller, 2004, 2005). The Permian bedrock units in Beckham County generally are coarser grained than Permian bedrock units in other parts of the study area and are dominated by the Elk City Sandstone and Doxey Shale (known as the Quartermaster Formation, undivided, in Texas), Cloud Chief Formation, and Whitehorse Group (Stanley and Miller, 2004, 2005) (figs. 11-12). Compared with the overlying Quaternary alluvium and terrace deposits, these Permian bedrock units generally act as barriers to groundwater flow, though some members of these units are minor aquifers in the study area. The most notable of these members is the youngest member of the Whitehorse Group, the Rush Springs Formation, which constitutes the Rush Springs aquifer to the east of the study area (fig. 11). Stratigraphically below the Whitehorse Group are the Dog Creek Shale, Blaine Formation, Flowerpot Shale, and Duncan (San Angelo) Sandstone, collectively known as the El Reno Group of Permian age (figs. 11-12). These mostly fine grained clastic and evaporite units underlie the Quaternary alluvium and terrace deposits in southern Beckham and northern Greer Counties (figs. 11-12) (Stanley and Miller, 2004, 2005). The shale-rich Flowerpot Shale and Hennessey Group, which generally act as barriers to groundwater flow, underlie the Quaternary alluvium and terrace deposits in the southern part of the study area south of Lake Creek (figs. 11-12) (Stanley and Miller, 2004, 2005).

\section{Cambrian Wichita Granite Group}

South and east of Lake Altus, the Quaternary alluvium and terrace deposits of the North Fork Red River aquifer are interrupted by igneous rocks of the Wichita Granite Group, the oldest unit exposed in the study area (figs. 11-12). These igneous rocks outcrop as isolated, steep-sided hills and mountains near Lake Altus and Tom Steed Reservoir. These igneous rocks are generally found at shallower depths in the Wichita Uplift than in surrounding geologic provinces (like the Anadarko Basin); however, detailed maps of depth to subsurface occurrences of igneous rocks have not been presented in publicly available literature. Igneous rocks of the Wichita Granite Group generally are assumed to be barriers to groundwater flow. 


\section{Hydrogeologic Framework}

A hydrogeologic framework is a three-dimensional representation of the aquifer and the surrounding geologic units at a scale that captures the regional controls on groundwater flow. A hydrogeologic framework was developed for the North Fork Red River aquifer and included a definition of the aquifer extent and potentiometric surface, as well as a description of the textural and hydraulic properties of aquifer materials. The hydrogeologic framework was used in the construction of the numerical groundwater-flow model of the North Fork Red River aquifer described in this report.

\section{Aquifer Extent}

The geographic extent of the North Fork Red River aquifer was updated from the OWRB (2015b) by using geologic maps (Johnson and others, 2003; Miller and Stanley, 2004; Stanley and Miller, 2004, 2005) and available well (and test-hole) completion reports (OWRB, 2015b; USGS, 2015a). The aquifer extent was expanded to include (1) the mapped alluvium adjacent to Elk Creek and tributaries up to the Washita County border, (2) the mapped alluvium and selected terrace deposits adjacent to Elm Fork Red River and tributaries in Greer County, (3) the mapped alluvium and terrace deposits along Sweetwater Creek near the Roger Mills County border, and (4) relatively thin terrace deposits along the southwest margin of a large terrace lobe in northern Jackson County (fig. 12). The update of the aquifer extent also resulted in the removal of areas previously designated as North Fork Red River aquifer, most notably a lobe of elevated terrace deposits in northwest Beckham County that the geologic maps show as small discontinuous areas of terrace deposits surrounded by Permian bedrock. Some areas of the North Fork Red River aquifer, though designated as Permian bedrock on the geologic maps (fig. 12), were included in the aquifer extent because they contained permitted wells (fig. 6) thought to produce water from the North Fork Red River aquifer (based on lithologic log evidence); the most notable examples of these areas are (1) south of Tom Steed Reservoir in southern Kiowa County and (2) west of Lake Altus in eastern Greer County.

Where present, the top of the North Fork Red River aquifer was defined for this report as the land-surface altitude obtained from a 10-meter (horizontal resolution) digital elevation model (DEM) (USGS, 2015b). The base of the North Fork Red River aquifer was mapped previously by Kent (1980) from a limited number of well logs and seismic data points. The Kent (1980) map of the aquifer base was verified for this report by using test-hole completion reports from Burton (1965), Hollowell (1965a, b), and Steele and Barclay (1965). The Kent (1980) map of the aquifer base also was modified for this report to incorporate additional data collected since 1980; these additional data included well (and test hole) completion reports from the USGS (2015a) and the OWRB (2015b). Well completion reports that included drillers' lithologic logs were analyzed for the presence of terms representing consolidated Permian bedrock units (such as "redbed," "gypsum," "mudrock," and "bedrock"). The altitude associated with the first occurrence of these terms in the logs was used as the altitude of the aquifer base. The lowest altitude listed on the lithologic log was considered to be the maximum possible altitude of the aquifer base at that location for logs that did not fully penetrate the North Fork Red River aquifer. Well completion reports and lithologic logs were available for most of the aquifer extent; however, few well completion reports and lithologic logs were available near the major streams of the study area. To provide bedrock-altitude control in areas near major streams, synthetic logs were placed about every mile along the major streams overlying the aquifer and given an aquifer base altitude that was $35 \mathrm{ft}$ below land surface; this 35 -ft estimate was the approximate mean depth of near-stream test-hole and cross-section data reported in literature from the study area (Barclay and Burton, 1953; Burton, 1965; Hollowell, 1965a, b). As part of this investigation, four Geoprobe hydraulic profiling tool (HPT) test holes (fig. 1) were drilled along the North Fork Red River in Beckham County; these test holes reached a mean depth of about $28 \mathrm{ft}$ in the aquifer, but some of those holes may have stopped at impenetrable caliche zones before reaching the full depth to bedrock.

Several faults are known to dissect the Permian bedrock units in parts of Beckham County (fig. 12); these faults were not evident in logs of the unconsolidated aquifer materials and, therefore, are not expected to affect groundwater flow. Gouin (1927) identified the Beckham County Fault (fig. 12) primarily from the thickness of North Fork Red River aquifer deposits; wells on the southern (upthrown) side of the fault penetrated about $50 \mathrm{ft}$ of aquifer thickness, and wells on the northern (downthrown) side of the fault penetrated up to $200 \mathrm{ft}$ of aquifer thickness. Some areas of the aquifer, usually those with few well completion reports, had less than $30 \mathrm{ft}$ of aquifer thickness, and these areas were assigned a minimum aquifer thickness of $30 \mathrm{ft}$ for this report. The aquifer thickness, as used in this report, is the difference between the land-surface (aquifer-top) altitude and the bedrock (aquifer-base) altitude; the aquifer saturated thickness, as used in this report, is the difference between the water-table altitude and the bedrock (aquifer-base) altitude.

\section{Potentiometric Surface}

A potentiometric surface shows the altitude at which the water level would have stood in tightly cased wells at a specified time; the potentiometric surface is usually contoured or spatially interpolated from synoptic watertable-altitude measurements in many wells across the aquifer extent. A 1979 potentiometric map from Kent (1980) was used to define the potentiometric surface around 1980. A 2013 potentiometric surface was contoured from waterlevel altitudes measured between December 2012 and 
January 2013 in about 100 selected wells (fig. 14) by using measurement methods described in Cunningham and Schalk (2011). Those water-table-altitude measurements also were used as calibration data for the numerical groundwater-flow model described in this report (table 1; USGS 2015a). The 1979 and 2013 potentiometric surface maps did not include enough colocated water-level measurements to allow direct comparisons of water-level altitudes, but those maps are useful for showing the general directions of groundwater flow in the aquifer; groundwater flows perpendicular to potentiometric contours in the direction of decreasing contour altitudes (fig. 14). The general patterns and directions of groundwater flow were the same for the 1979 and 2013 potentiometric surface maps.

\section{Textural and Hydraulic Properties of Aquifer Materials}

The distribution and variability of textural and hydraulic properties of aquifer materials were assumed to be the primary controls on groundwater flow in the North Fork Red River aquifer. Drillers' lithologic log data were used to determine the textural properties of aquifer materials. Textural terms in each lithologic log (OWRB, 2015b) were standardized, categorized, and converted to percentage-coarse-material values by using the methods of Mashburn and others (2013). The percentagecoarse-material value for each lithologic log then was used to estimate and spatially interpolate the hydraulic properties of the North Fork Red River aquifer materials.

\section{Lithologic Log Standardization and Calculation of Percentage-Coarse-Material Values}

Lithologic logs included terms such as "redbed," “shale," "mudrock," and "gypsum” to describe Permian bedrock units and terms such as "gravel," "sand," "silt,” and "clay” to describe the texture of unconsolidated alluvium and terrace deposits of the North Fork Red River aquifer. However, terms used for lithologic descriptions varied between drillers. To simplify and standardize the lithologic logs, lithologic descriptions of unconsolidated deposits were reclassified into four lithologic categories (clay, silt, sand, and gravel) that were assumed to have quartile ranges of percentagecoarse material (0-25, 25-50, 50-75, and 75-100 percent coarse material, respectively). The midpoint of the respective quartile range $(12.5,37.5,62.5$, or 87.5 percent coarse material, respectively) was, thus, assigned to each lithologic depth interval by using the same method as Mashburn and others (2013). The percentage-coarse-material value for each lithologic log was computed as the thickness-weighted mean of percentage-coarse-material values assigned to the unconsolidated lithologic categories in the log. The maximum percentage-coarse-material value for any lithologic log was 87.5 percent (all gravel), and the minimum percentage-coarsematerial value for any lithologic log was 12.5 percent (all clay).

More than 1,500 lithologic logs were used for the percentage-coarse-material analysis, and at least 500 of those logs fully penetrated the aquifer. Limitations of using lithologic logs include errors in spatial location, depths of intervals, and detail of lithologic descriptions. Logs with obvious errors were corrected to extract as much useful information as possible; logs with inscrutable errors were discarded. The bedrock contact was interpolated by using professional judgment and geologic information from previous publications; the bedrock contact was approximated in areas where few lithologic logs were available.

\section{Spatial Distribution of Percentage-Coarse- Material Values}

The percentage-coarse-material values for each lithologic log were spatially interpolated across the aquifer by using the inverse-distance-weighted (IDW) interpolation method (Esri, Inc., 2017), where values nearest the interpolated location have the greatest influence on the interpolated value at that location. The IDW interpolation used a power of 3 and a neighborhood of 300 . The power is the exponent to which the inverse of the distance between the interpolated location and nearby values is raised, and the neighborhood is the maximum number of nearby values used in the interpolation. 


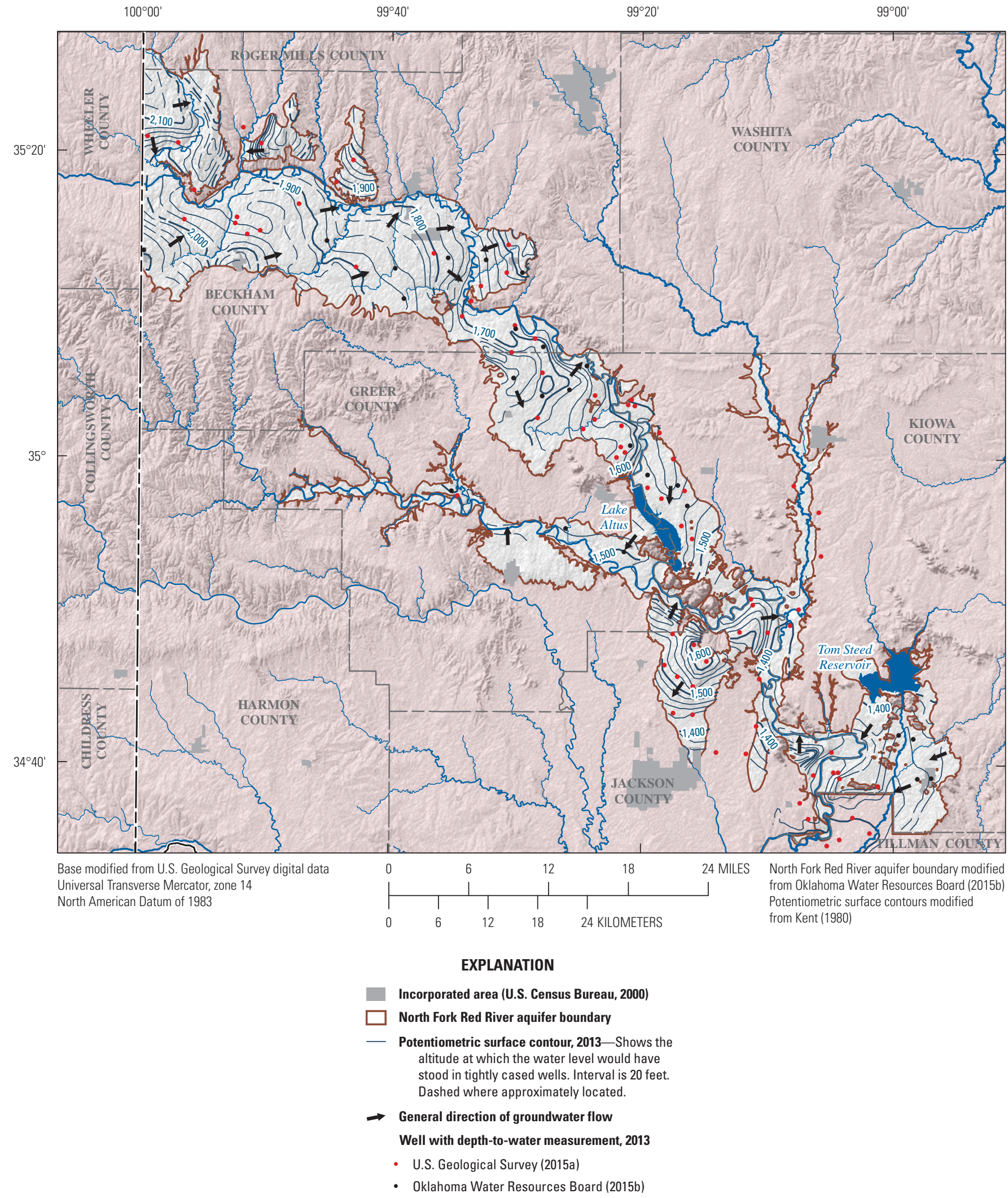

Figure 14. Potentiometric surface contours and general direction of groundwater flow in the North Fork Red River aquifer, 2013. 


\section{Hydraulic Properties}

Ellis and others (2017) developed a linear mathematical relation between percentage-coarse-material values and horizontal hydraulic conductivity (Kh) determined from core material. The core material was obtained from alluvium and terrace deposits of the Canadian River in western Oklahoma that were similar to the North Fork Red River alluvium and terrace deposits in terms of geologic setting and provenance. The estimated mean Kh for each lithologic log location in the North Fork Red River aquifer was calculated by using the Ellis and others (2017) relation:

$$
\mathrm{Kh}=(1.25 \times \mathrm{Pcm})-12.4
$$

where

$$
\begin{aligned}
& \mathrm{Kh} \quad \text { is the horizontal hydraulic conductivity in feet } \\
& \text { per day; and } \\
& \mathrm{Pcm} \quad \text { is the percentage-coarse-material value. }
\end{aligned}
$$

Using the Ellis and others (2017) relation, the estimated Kh determined for lithologic logs in the North Fork Red River aquifer must be within the range of 3 to 97 feet per day (ft/d; 12.5 to 87.5 percent coarse material). The mean and median estimated Kh determined from lithologic logs were $52 \mathrm{ft} / \mathrm{d}$ and $57 \mathrm{ft} / \mathrm{d}$, respectively. The range and distribution of $\mathrm{Kh}$ estimated from lithologic logs were similar to the range and distribution of Kh measured with depth in four Geoprobe HPT logs (McCall, 2010; Geoprobe Systems, 2015; figs. 1 and 15). $\mathrm{Kh}$ measured in the HPT logs ranged from 1 to $97 \mathrm{ft} / \mathrm{d}$ with a median of $64 \mathrm{ft} / \mathrm{d}$ (fig. 15) and a mean of $61 \mathrm{ft} / \mathrm{d}$ (table 7). The $\mathrm{Kh}$ measured from the HPT logs generally was greater than the Kh estimated from the lithologic logs; however, these Kh values are difficult to compare because they were determined by using different methods. The Kh values measured from the HPT logs represent point measurements of Kh at every $0.6 \mathrm{in}$. of depth at only four locations (all near the present channel of the North Fork Red River, fig. 1), and the Kh values estimated from the lithologic logs were averaged from generalized descriptions of drill cuttings.

The relation between percentage-coarse-material (or Kh) values and specific yield (Sy) is nonlinear and depends on the sorting and dominant size of aquifer materials (Johnson, 1967). In general, Sy is maximized for medium to coarse sand, which tends to be well sorted; Sy decreases as the aquifer materials become finer (and a greater percentage of pore water is retained by surface tension) or coarser (and sorting becomes poorer) (Johnson, 1967). Dominant grain size and sorting cannot be derived from lithologic logs, and Sy is usually estimated by using long-duration multi-well aquifer tests (Neuman, 1987).

Three multi-well aquifer tests (AT1, AT2, and AT3, fig. 1, table 7) were performed in the alluvium and terrace deposits of the North Fork Red River aquifer in Beckham County in November-December 1954 by the USGS and the OWRB (then known as the Oklahoma Planning and Resource Board) (USGS, 2015a). The aquifer tests were performed on pumping (irrigation) wells, each with three observation wells 170-360 ft away. The irrigation wells were pumped for up to 66 hours at a constant rate while drawdown was measured in the observation wells. The aquifer test data (observation-well water-level changes over time) were analyzed by using the modified Theis (1935) nonequilibrium methods of Cooper and Jacob (1946). Mean transmissivities resulting from these aquifer tests (AT1, AT2, and AT3) were 7,500, 5,900, and 7,900 feet squared per day $\left(\mathrm{ft}^{2} / \mathrm{d}\right)$, respectively, and mean hydraulic conductivities were 90.4, 40.7, and $95.2 \mathrm{ft} / \mathrm{d}$, respectively. Sy values calculated from these aquifer tests were $0.064,0.051$, and 0.152 respectively (table 7 ).

Another multi-well aquifer test (AT4, fig. 1, table 7) was performed near Lake Altus by Kent (1980) and Paukstaitis (1981). A well was pumped at a rate of $100 \mathrm{gal} / \mathrm{min}$ for 50 hours while measurements of drawdown were recorded at an observation well $75 \mathrm{ft}$ away. The aquifer-test data were analyzed for this report by using the modified Theis (1935) nonequilibrium method of Cooper and Jacob (1946). The transmissivity calculated from this aquifer test by using the Prickett (1965) late match method was 4,480 $\mathrm{ft}^{2} / \mathrm{d}$, and the hydraulic conductivity was $124 \mathrm{ft} / \mathrm{d}$ (Kent, 1980). An Sy value of 0.057 was calculated from the Kent (1980) and Paukstaitis (1981) aquifer test data by using the Cooper and Jacob (1946) method with the Prickett (1965) late-match transmissivity (table 7); however, the numerical groundwater-flow model of Kent (1980) used a mean Sy value of 0.246. A set of multiwell aquifer tests from the nearby and contiguous Tillman Terrace aquifer (fig. 1) also produced Sy values lower than those used in the Kent (1980) model for the North Fork Red River aquifer; these Sy values ranged from 0.010 to 0.087 , with a mean of 0.036 (Barclay and Burton, 1953). However, Barclay and Burton (1953) stated that the maximum estimated Sy value (0.087) was most representative of the aquifer because the other Sy values were estimated from multi-well aquifer tests of short duration.

Based on available multi-well aquifer test data (table 7) and published studies (Ryter and Correll, 2016; Ellis and others, 2017), a mean Sy value of 0.12 was estimated for the North Fork Red River aquifer. Values for selected other hydraulic properties were assumed because they were too difficult or expensive to measure and because they were not available in published reports about the study area. The ratio of horizontal to vertical hydraulic conductivity (anisotropy) of the Quaternary alluvium and terrace deposits was assumed to be 3, which matched the anisotropy used for a numerical groundwater-flow model of the Canadian River alluvial aquifer of western Oklahoma (Ellis and others, 2017). The hydraulic conductivity for the Permian bedrock units was assumed to be constant at $0.003 \mathrm{ft} / \mathrm{d}$ and was comparable to hydraulic conductivity estimates for Permian shale units in southwest Oklahoma reported by Sullivan (1998). The specific storage and anisotropy values for the Permian bedrock units were assumed to be constant at 0.00001 and 10, respectively; these values were comparable to those used by Ryter and Correll (2016) and Ellis and others (2017) for Permian bedrock units in northwest Oklahoma. 

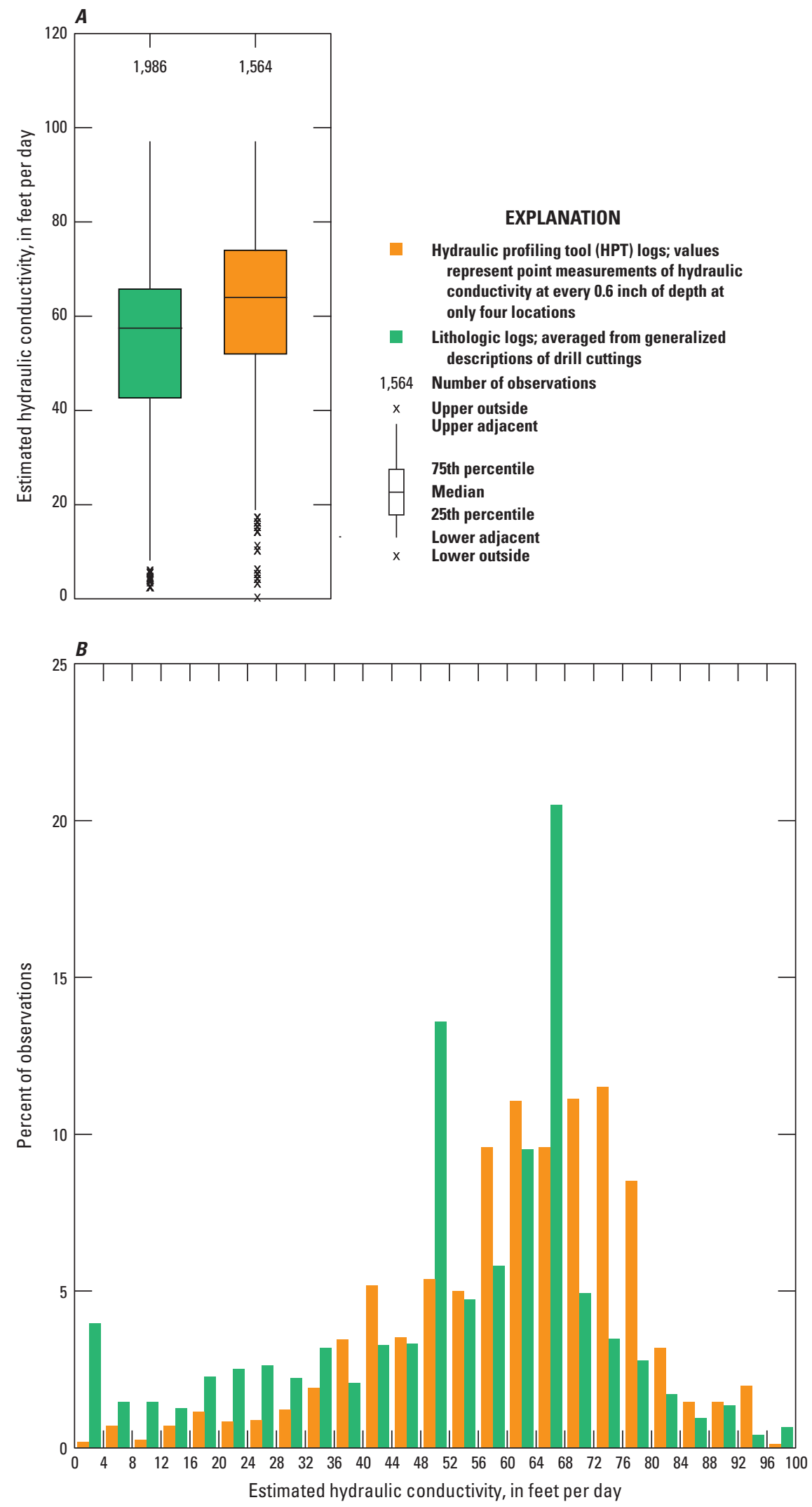

Figure 15. Distributions of estimated hydraulic conductivity observations in the North Fork Red River aquifer. 
Table 7. Hydraulic properties calculated from hydraulic profiling tool test holes and multi-well aquifer tests in the North Fork Red River aquifer.

[NAD 83, North American Datum of 1983; Sy, specific yield; ft²/d, foot squared per day; Kh, hydraulic conductivity; ft/d, foot per day; --, data not available]

\begin{tabular}{|c|c|c|c|c|c|c|c|c|c|c|}
\hline \multirow[b]{2}{*}{$\begin{array}{c}\text { Station } \\
\text { name } \\
\text { (fig. 1) }\end{array}$} & \multirow[b]{2}{*}{ Data source } & \multirow[b]{2}{*}{ Date } & \multirow[b]{2}{*}{ County } & \multirow[b]{2}{*}{$\begin{array}{l}\text { Analysis } \\
\text { methods }\end{array}$} & \multicolumn{3}{|c|}{ Test hole or pumping well } & \multicolumn{3}{|c|}{ Hydraulic properties } \\
\hline & & & & & $\begin{array}{l}\text { Station } \\
\text { number }\end{array}$ & $\begin{array}{l}\text { Latitude } \\
\text { (NAD } 83 \\
\text { degrees) }\end{array}$ & $\begin{array}{c}\text { Longitude } \\
\text { (NAD } 83 \\
\text { degrees) }\end{array}$ & $\begin{array}{l}\text { Mean } \\
\text { Sy }\end{array}$ & $\begin{array}{c}\text { Transmis- } \\
\text { sivity } \\
\left(\mathrm{ft}^{2} / \mathrm{d}\right)\end{array}$ & $\begin{array}{c}\text { Mean } \\
\text { Kh } \\
\text { (ft/d) }\end{array}$ \\
\hline \multicolumn{11}{|c|}{ Hydraulic profiling tool test holes } \\
\hline HPT1 & $\begin{array}{l}\text { U.S. Geological } \\
\text { Survey (2015a) }\end{array}$ & $4 / 1 / 2014$ & Beckham & McCall (2010) & 351800099524801 & 35.300113 & -99.879995 & -- & -- & 55.4 \\
\hline HPT2 & $\begin{array}{l}\text { U.S. Geological } \\
\quad \text { Survey (2015a) }\end{array}$ & $4 / 1 / 2014$ & Beckham & McCall (2010) & 351759099492401 & 35.299716 & -99.82335 & -- & -- & 64.0 \\
\hline HPT4 & $\begin{array}{l}\text { U.S. Geological } \\
\text { Survey (2015a) }\end{array}$ & $4 / 2 / 2014$ & Beckham & McCall (2010) & 351552099414001 & 35.264451 & -99.694512 & -- & -- & 62.7 \\
\hline HPT5 & $\begin{array}{l}\text { U.S. Geological } \\
\text { Survey (2015a) }\end{array}$ & $4 / 2 / 2014$ & Beckham & McCall (2010) & 350949099302701 & 35.163637 & -99.507607 & -- & -- & 62.1 \\
\hline Mean: & & & & & & & & -- & -- & 61.1 \\
\hline Range: & & & & & & & & -- & -- & $55.4-64.0$ \\
\hline \multicolumn{11}{|c|}{ Multi-well aquifer tests } \\
\hline AT1 & $\begin{array}{l}\text { U.S. Geological } \\
\quad \text { Survey (2015a) }\end{array}$ & December 7-9, 1954 & Beckham & $\begin{array}{l}\text { Cooper and Jacob } \\
\text { (1946) }\end{array}$ & 351657099584701 & 35.282552 & -99.980108 & 0.064 & 7,500 & 90.4 \\
\hline AT2 & $\begin{array}{l}\text { U.S. Geological } \\
\quad \text { Survey (2015a) }\end{array}$ & $\begin{array}{l}\text { November 15-19, } \\
1954\end{array}$ & Beckham & $\begin{array}{l}\text { Cooper and Jacob } \\
\text { (1946) }\end{array}$ & 351339099424001 & 35.227551 & -99.711487 & 0.051 & 5,900 & 40.7 \\
\hline AT3 & $\begin{array}{l}\text { U.S. Geological } \\
\quad \text { Survey (2015a) }\end{array}$ & $\begin{array}{l}\text { November 12-17, } \\
1954\end{array}$ & Beckham & $\begin{array}{l}\text { Cooper and Jacob } \\
\text { (1946) }\end{array}$ & 351438099370801 & 35.24394 & -99.619262 & 0.152 & 7,900 & 95.2 \\
\hline \multirow[t]{3}{*}{ AT4 } & $\begin{array}{l}\text { Paukstaitis (1981) } \\
\text { and Kent (1980) }\end{array}$ & March 15-18, 1979 & Kiowa & $\begin{array}{l}\text { Cooper and Jacob } \\
\text { (1946) }\end{array}$ & -- & 34.969 & -99.321 & -- & 3,540 & 98.9 \\
\hline & & & & $\begin{array}{l}\text { Prickett (1965), } \\
\text { early match }\end{array}$ & -- & 34.969 & -99.321 & -- & 4,680 & 130 \\
\hline & & & & $\begin{array}{l}\text { Prickett (1965), } \\
\text { late match with } \\
\text { Cooper and } \\
\text { Jacob (1946) } \\
\text { analysis of Sy }\end{array}$ & -- & 34.969 & -99.321 & ${ }^{1} 0.057$ & 4,480 & 124 \\
\hline Mean²: & & & & & & & & 0.081 & 5,780 & 78.3 \\
\hline Range $^{2}$ : & & & & & & & & $\begin{array}{c}0.057- \\
0.152\end{array}$ & $\begin{array}{c}3,540- \\
7,900\end{array}$ & 40.7-98.9 \\
\hline
\end{tabular}

${ }^{1}$ Calculated using data from Paukstaitis (1981, fig. 21) and Kent (1980, p. 19). Paukstaitis (1981) and Kent (1980) did not calculate specific yield, but presented the information needed to calculate specific yield.

${ }^{2}$ Except for Sy, mean and range do not include Prickett (1965) analysis for AT4. 


\section{Conceptual Groundwater-Flow Model}

A conceptual groundwater-flow model (hereafter referred to as the conceptual model) is a simplified description of the major inflow and outflow sources (hydrologic boundaries) of a groundwater-flow system as well as an accounting of the estimated mean flows from those sources (water budget, table 8) for a specified period of time. A conceptual model was developed for the North Fork Red River aquifer to constrain the construction and calibration of a numerical groundwaterflow model (hereafter referred to as the numerical model) that reasonably represented the groundwater-flow system. The conceptual-model water budget (table 8) estimated mean annual inflows to and outflows from the North Fork Red River aquifer for the period 1980-2013 and included a sub-accounting of mean annual inflows and outflows for the portions of the aquifer that were upgradient and downgradient from Lake Altus, which were determined by using the 11120302 subwatershed boundary (figs. 2 and 16).

\section{Hydrologic Boundaries}

Hydrologic boundaries in the conceptual model represent real-world sources (inflows) and sinks (outflows) of water to the aquifer. Boundaries that act as both inflows and outflows, depending on which flow component dominates, may be referred to as net inflows or outflows.

\section{Recharge}

Recharge is the predominant inflow to the North Fork Red River aquifer. Recharge, as defined in this report, is the amount of precipitation (over a given time) that reaches the saturated zone through the process of infiltration through the unsaturated zone. Factors that affect recharge rates are precipitation rates, ET rates, permeability and moisture capacity of the unsaturated zone, and slope of the land surface. Recharge rates are difficult to measure directly because they vary over short spatial and temporal scales; therefore, recharge

Table 8. Conceptual groundwater-flow model mean annual water budget for the North Fork Red River aquifer, 1980-2013.

[All units in acre-feet per year; --, not quantified; ET, evapotranspiration; \%, percent]

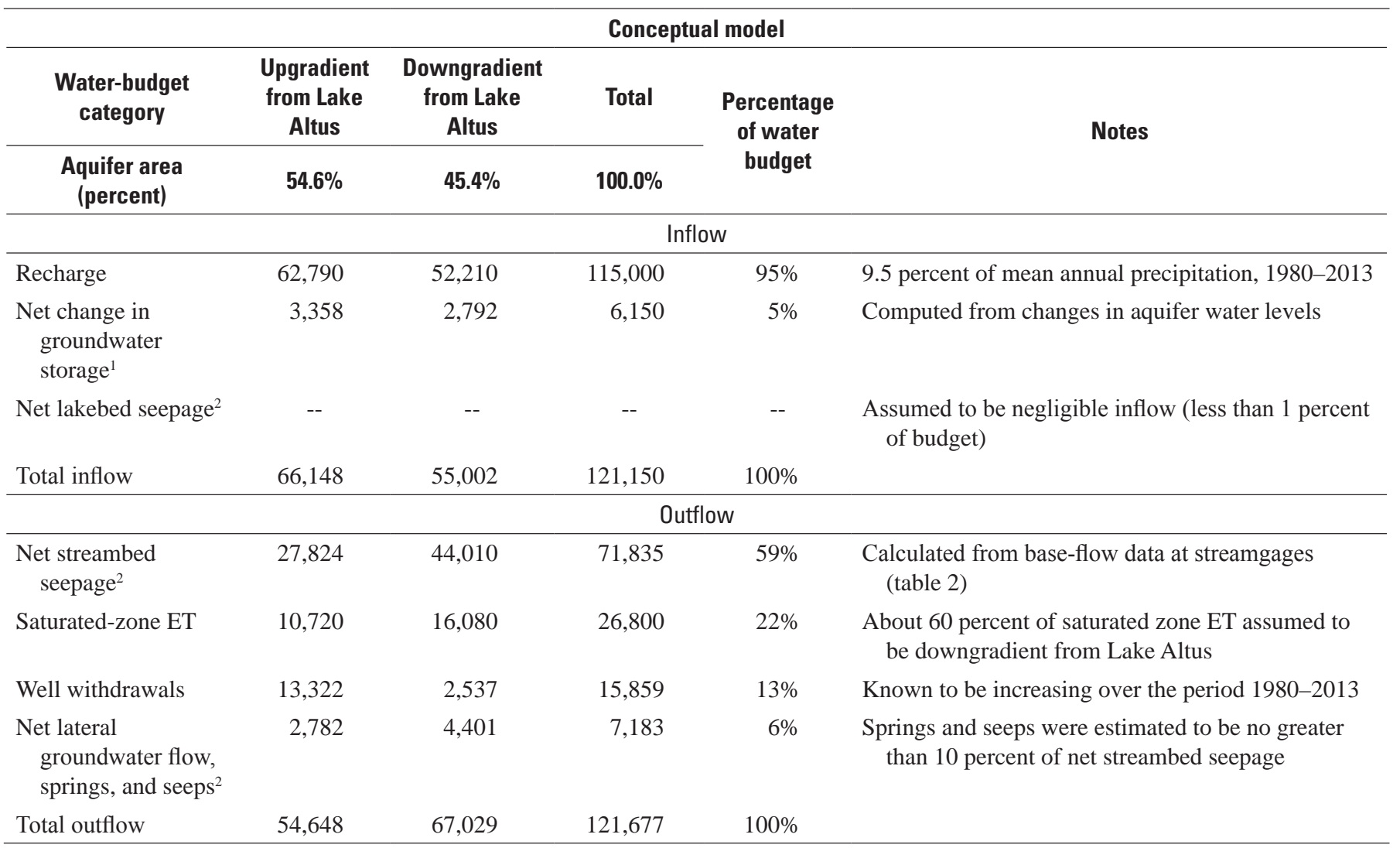

${ }^{1}$ Positive values indicate loss of groundwater storage from the aquifer. Loss of groundwater storage is reported as an aquifer inflow for comparison with the numerical groundwater-flow model in which storage loss is represented as a positive value for mass balance purposes (fig. 16, table 14).

${ }^{2}$ Net lakebed seepage, net streambed seepage, and net lateral groundwater flow represent the net effect of aquifer inflows and outflows. 


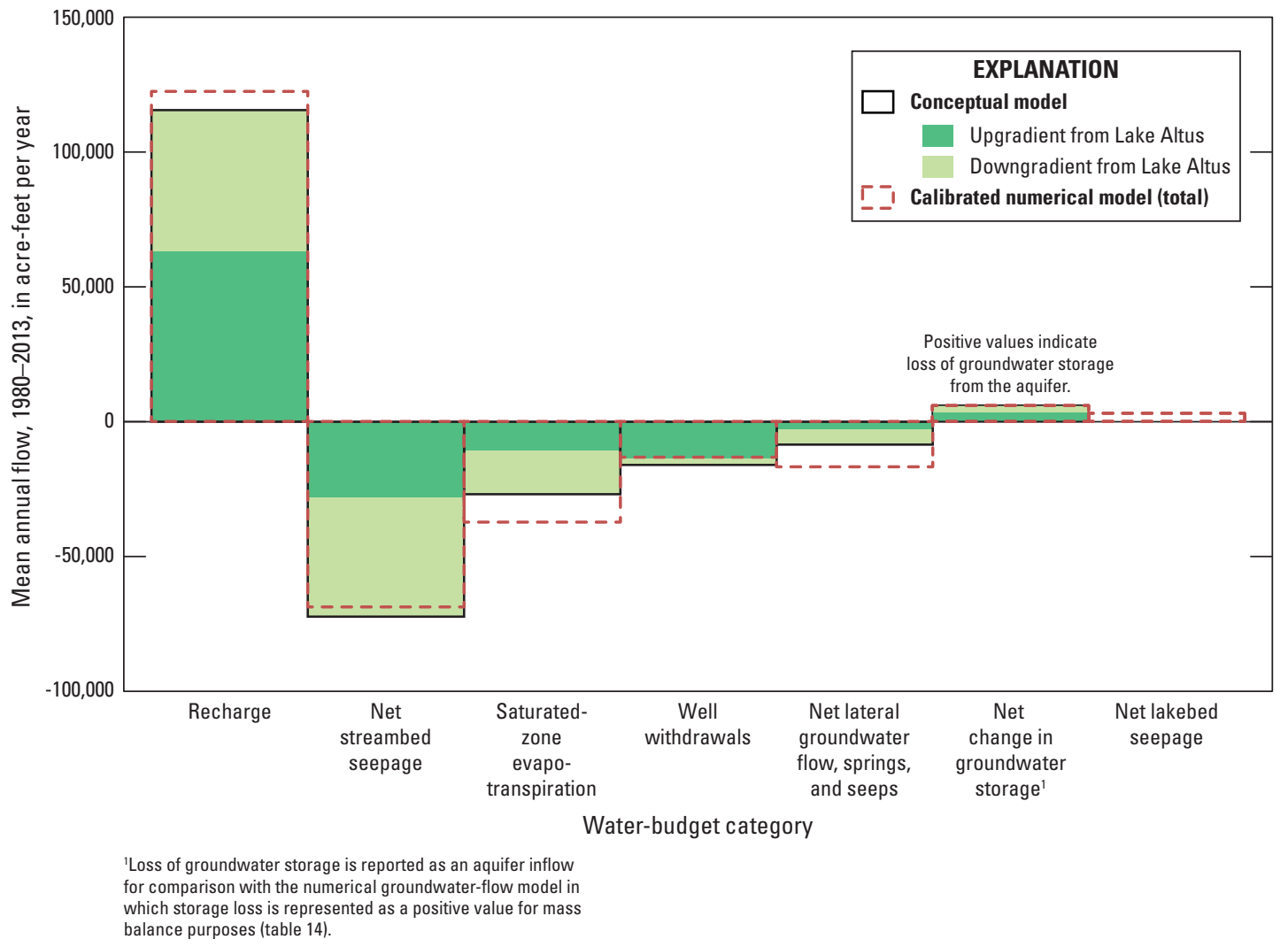

Figure 16. Mean annual flow by water-budget category for the conceptual model and the calibrated numerical model of the North Fork Red River aquifer, 1980-2013.

rates are often estimated by using multiple methods. Some methods estimate recharge at specified points, and some methods estimate recharge at the basin or regional scale. The basin-scale RORA and PART (Rorabaugh, 1964; Rutledge, 1998) methods, which are based on streamgage data, were most appropriate for the scale of this study; however, most streams in the study area violated the assumptions of these methods because (1) they were losing streams during part of the year, (2) they were regulated by large reservoirs, or (3) they exceeded the recommended drainage-basin area limit of $500 \mathrm{mi}^{2}$.

The RORA method uses a recession-curve displacement technique to estimate groundwater recharge from each storm period based on a one-dimensional analytical model of groundwater discharge to a fully penetrating stream (the streambed altitude is the aquifer-base altitude) in an idealized aquifer with uniform spatial recharge (Rorabaugh, 1964; Rutledge, 1998). This method approximates recharge at times when ET and groundwater use are minimal, during which base flow is assumed to be groundwater discharge that is approximately equal to recharge. The RORA method was used to estimate annual recharge at the Sweetwater streamgage (07301420) on Sweetwater Creek, which has a drainage-basin area of $437 \mathrm{mi}^{2}$. This streamgage was the only streamgage in the study area that did not violate the suggested drainage-area limitation for application of the RORA method. Annual recharge at the Sweetwater streamgage (07301420) for the period of record 1986-2013 ranged from $0.10 \mathrm{in} / \mathrm{yr}$ in 2012 to $1.45 \mathrm{in} / \mathrm{yr}$ in 1997; the RORA-estimated mean annual recharge for that period was $0.60 \mathrm{in} / \mathrm{yr}$ or about 2.4 percent of the mean annual precipitation (25.29 in/yr) for the 1980-2013 period at the Erick (342944) climate station. The RORA-estimated mean annual recharge $(0.60 \mathrm{in} / \mathrm{yr})$ was about 31 percent of the mean annual recharge (1.91 in/yr) computed by using the SoilWater-Balance (SWB) code (Westenbroek and others, 2010); the application of the SWB code is described in detail in the Recharge and the Soil-Water-Balance Code section of this report. The RORA-estimated mean annual recharge could be biased low, however, if recharge flowed across the drainagebasin boundary without discharging to Sweetwater Creek.

The water-table fluctuation (WTF) method (Healy and Cook, 2002) also was used to estimate recharge to the North Fork Red River aquifer. The WTF method is based on the premise that short-term (hours to a few days) rises in continuously recorded groundwater levels in unconfined aquifers are caused by recharge arriving at the saturated zone following a period of precipitation. The method is best applied to aquifers with shallow water tables that display rapid water-level rises and declines in response to precipitation. The method cannot distinguish between recharge 
from precipitation and recharge from other sources such as irrigation return flow or streambed seepage. Using the WTF method, recharge $(R)$ was calculated as the sum of individual water-level rises in response to precipitation:

$$
\mathrm{R}=\mathrm{Sy} \Delta \mathrm{h} / \Delta \mathrm{t}
$$

where

$$
\begin{aligned}
\text { Sy } & \text { is the specific yield (dimensionless), } \\
\Delta \mathrm{h} & \text { is the change in water level, in inches, and } \\
\Delta t & \text { is the change in time, in months. }
\end{aligned}
$$

Continuous water-level recorder wells CR1 and CR2 (fig. 1), which were downgradient from many permitted production wells, were not ideal for estimating recharge by using the WTF method because few water-level rises in response to precipitation were observed. Monthly recharge during 2014 was estimated at continuous water-level recorder well CR3 (fig. 1), which was upgradient from permitted production wells. The barometric-pressure-corrected waterlevel hydrograph from CR3 (fig. 17, table 1) showed some water-level rises in response to precipitation, which totaled 22.4 in. at the Hobart climate station (HOBA, fig. 1) in 2014 (Oklahoma Mesonet, 2015). The minimum estimated monthly recharge at CR3 was $0.0 \mathrm{in}$. for the month of January because no precipitation was observed in that month. When using an Sy of 0.12, the maximum estimated monthly recharge at CR3 was 0.5 in. during May, and estimated annual recharge at CR3 was 2.4 in. (about 11 percent of precipitation) during 2014.

Estimates of mean annual recharge rates for other Quaternary alluvium and terrace deposits with similar climate in western Oklahoma include $2.3 \mathrm{in} / \mathrm{yr}$ (Adams and Bergman, 1996), about 8 percent of mean annual precipitation for that study; 3.15 in/yr (Barclay and Burton, 1953), about 11 percent of mean annual precipitation for that study; and $1.74 \mathrm{in} / \mathrm{yr}$

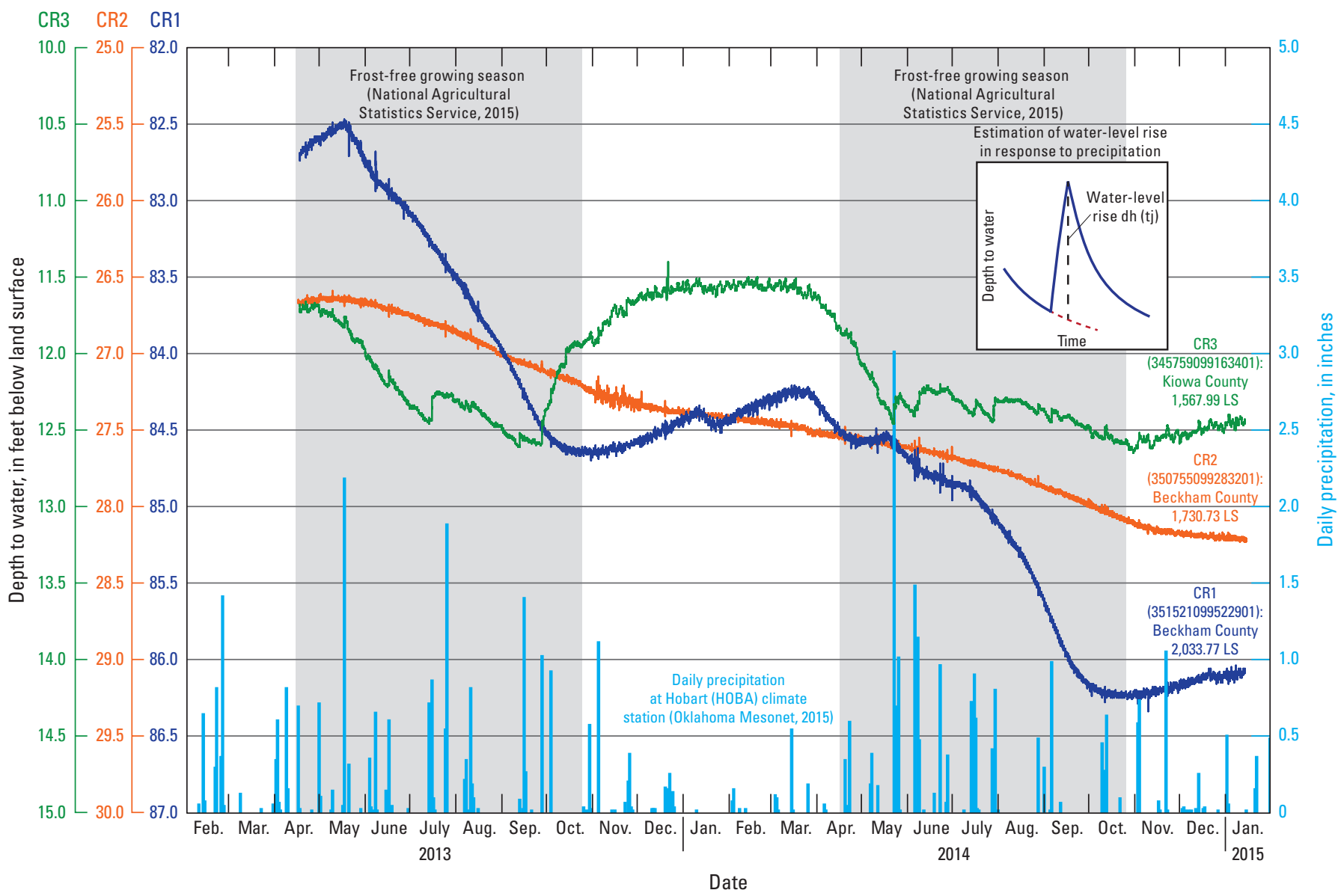

LS, land-surface altitude in feet above North American Vertical Datum of 1988; Precipitation data from Oklahoma Mesonet (2015) Hobart weather station; Depth to water data from U.S. Geological Survey (2015a)

Figure 17. Daily precipitation and depth to water in continuous water-level recorder wells completed in the North Fork Red River aquifer, February 2013 through January 2015. 
(Steele and Barclay, 1965), about 7 percent of mean annual precipitation for that study. Based on estimated annual recharge percentages from these studies and the WTF method, the mean annual recharge rate to the North Fork Red River aquifer for the period 1980-2013 was estimated to be about $2.77 \mathrm{in} / \mathrm{yr}$ or 9.5 percent of the mean annual precipitation (29.2 in/yr, table 3) for the same period. This 1980-2013 mean annual recharge rate of $2.77 \mathrm{in} / \mathrm{yr}(0.231$ feet per year [ft/yr]), multiplied by the aquifer area of 497,582 acres, is equivalent to a mean annual recharge volume of about 115,000 acre- $\mathrm{ft} / \mathrm{yr}$ (table 8). The mean annual recharge volumes upgradient and downgradient from Lake Altus, apportioned by percentage of aquifer area (54.6 and 45.4 percent, respectively), were about 62,800 and 52,200 acre-ft/yr, respectively (table 8).

\section{Lateral Groundwater Flows}

Upgradient from Lake Altus, the alluvium and terrace deposits of Wheeler County, Texas (fig. 12), which are adjacent to the deposits of the North Fork Red River aquifer, were assumed to exchange lateral groundwater flow with the aquifer. The rate and direction of lateral groundwater flow across the Texas border may vary, however, during seasonally and decadally alternating wet and dry periods. During a severe drought in 2013 (fig. 3), the Texas border was roughly perpendicular to most of the mapped potentiometric surface contours (fig. 14) and, therefore, was roughly parallel to the direction of most groundwater flow (generally toward the North Fork Red River). Based on the configuration of the 2013 potentiometric surface (fig. 14), the net lateral groundwater flow across the Texas border may have accounted for a small inflow to the aquifer in 2013. The potentiometric surfaces for 1951 and 1979 (Kent, 1980), also mapped during dry periods (fig. 3A), show a configuration similar to that of fig. 14. No water-table-altitude data were available from west of the Texas border; therefore, rates of lateral groundwater flow across the Texas border could not be quantified.

Downgradient from Lake Altus, lateral groundwater flows across the Tillman County border were expected to be outflows based on the potentiometric surfaces of the North Fork Red River aquifer (fig. 14) and the Tillman Terrace aquifer (Barclay and Burton, 1953; Osborn, 2002). Based on estimates of the mean hydraulic gradient, hydraulic conductivity, and saturated thickness in the area, net lateral groundwater flows across the Tillman County border were estimated to be small outflows of about 1,100 acre-ft/yr.

Net lateral groundwater flows exchanged with the surrounding Permian bedrock units (predominantly shale and siltstone with relatively low hydraulic conductivity) were assumed to be a negligible part of the conceptual-model water budget of the North Fork Red River aquifer. No estimates of the flow between the Permian bedrock and the aquifer were available in published reports.

\section{Streambed Seepage}

Synoptic streamflow measurements (also known as seepage-run measurements) were collected by using the methods of Rantz and others (1982) during a period of minimal runoff on March 11-13, 2013 (USGS, 2015a). These measurements were intended to capture tributary-inflow and base-flow conditions across the aquifer at one point in time. The synoptic streamflow measurements were used to calculate net streambed seepage and classify stream reaches as gaining (having a downstream increase in base flow) or losing (having a downstream decrease in base flow). These March 2013 streambed-seepage data (fig. 18) show that (1) most small tributaries that originate away from the aquifer carried negligible (less than $1 \mathrm{ft}^{3} / \mathrm{s}$ ) base flows to the North Fork Red River, (2) stream reaches upstream from the Texas border generally were gaining, (3) stream reaches between the Texas border and Lake Altus generally were losing, and (4) stream reaches downstream from Lake Altus generally were gaining. However, the March 2013 streambed-seepage data were collected during a severe drought period (fig. 3) and therefore may be more representative of less-frequent drought conditions than typical late-winter base-flow conditions. Other synoptic streamflow measurements were reported by Smith and others (2003) and Stephens (2003) for reaches upstream from Lake Altus, but most of these measurements captured some streamflow runoff component and were not ideal for base-flow comparisons. A set of synoptic streamflow measurements from July 2003 (Stephens, 2003), another dry year, reinforced that reaches of the North Fork Red River upstream from Lake Altus can be losing or dry in the summer months when ET, irrigation, and public-supply water demands are greatest.

Annual and monthly base flows (fig. 19; table 2, only mean annual base flows shown) were computed at streamgages for the period 1980-2013 by using the BaseFlow Index (BFI) code (Wahl and Wahl, 1995) in the USGS Groundwater Toolbox (Barlow and others, 2015) and streamflow data from USGS (2015a). The BFI code uses the minimum streamflow in a moving n-day window as a basis for hydrograph separation, and a window of 5 days was used for all streamgages. Base-flow computation at regulated streamgages can be complicated by releases from large reservoirs and floodwater-retarding structures because these releases (and the subsequent bank storage releases associated with these releases) are usually indistinguishable from natural base flows. For this reason, hydrograph separation methods may overestimate base flows at regulated streamgages; the base flows computed for those regulated streamgages are useful, however, as a maximum limit on estimated base flow. 


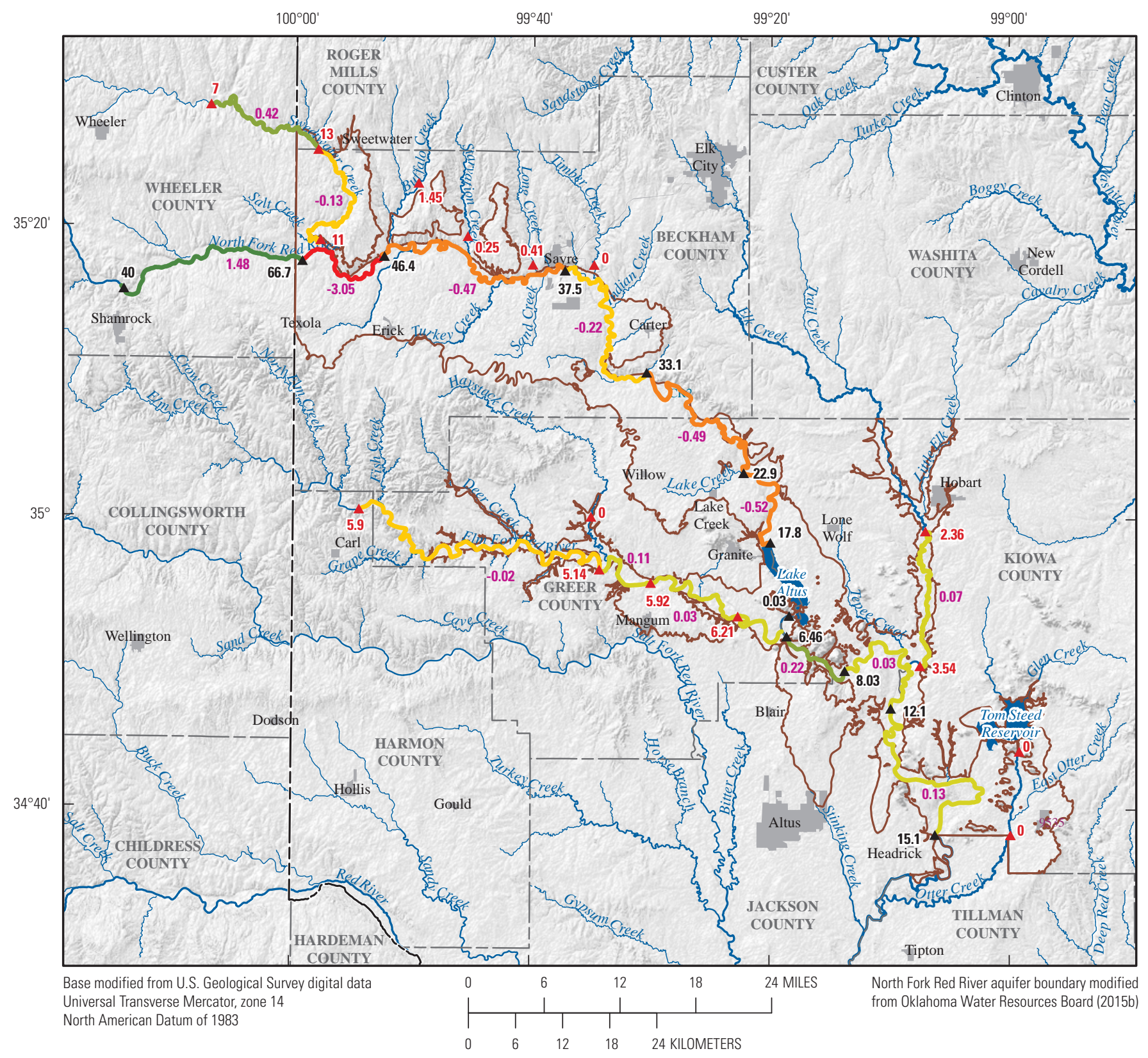

\section{EXPLANATION}

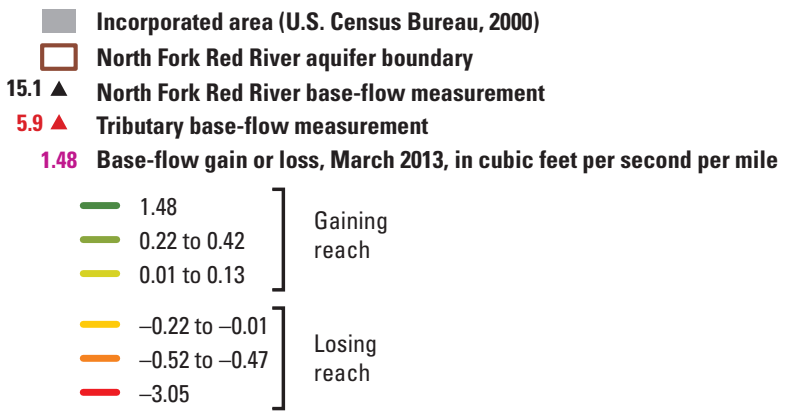

Figure 18. Base-flow measurements with gaining and losing reaches of the North Fork Red River and tributaries, March 2013. 

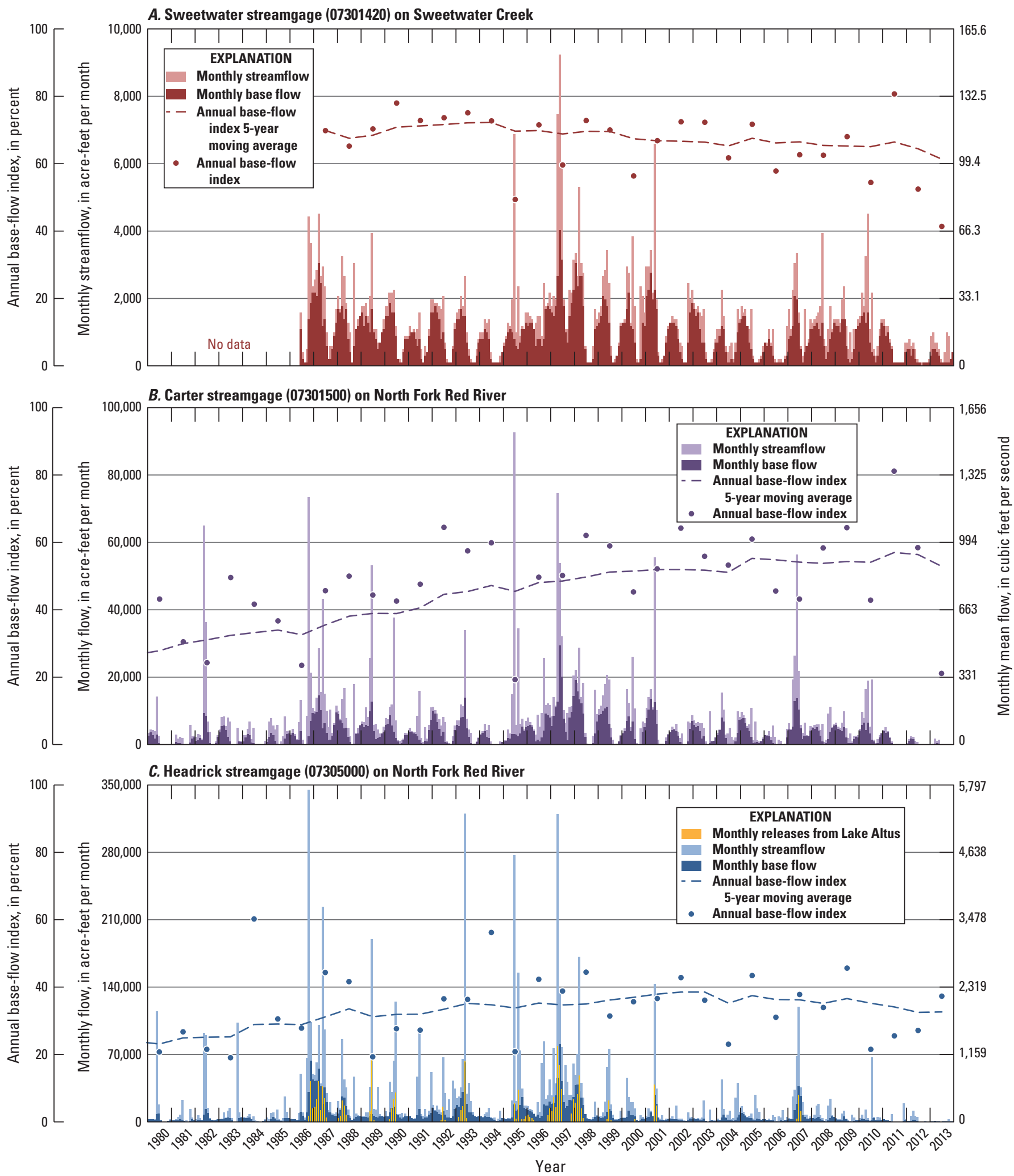

Figure 19. Monthly streamflow, monthly base flow, and annual base-flow index for $A$, Sweetwater streamgage (07301420) on Sweetwater Creek; B, Carter streamgage (07301500) on North Fork Red River; and C, Headrick streamgage (07305000) on North Fork Red River, 1980-2013. 
Streambed seepage is the predominant outflow from the North Fork Red River aquifer. The annual net streambed seepage upgradient from Lake Altus was estimated to be 27,824 acre-ft/yr (table 8) and was calculated as the mean annual base flow at the Carter streamgage (07301500) minus the mean annual base flows at the Shamrock (07301300) and Kelton (07301410) streamgages (table 2). Because no streamgages are located between the Carter streamgage (07301500) and Lake Altus (a distance of about 27 river miles), additional streambed seepage may occur in this reach that was not represented in the calculation. The annual net streambed seepage downgradient from Lake Altus was estimated to be 44,010 acre-ft/yr (table 8) and was calculated as the mean annual base flows at the Headrick (07305000) and Snyder (07307010) streamgages minus the mean annual base flows at the Carl (07303400) and Hobart (07304500) streamgages plus 50 percent of the mean annual releases from Lake Altus (table 2). This 50-percent figure was assumed to represent the unknown portion of annual releases that flowed to the North Fork Red River aquifer as bank storage and streambed seepage and was later discharged to the North Fork Red River as base flow. Mean annual releases from Lake Altus for the period 1980-2013 were about 35,100 acre-ft/yr (U.S. Bureau of Reclamation, 2015b).

\section{Lakebed Seepage}

Net lakebed seepage between the North Fork Red River aquifer and Lake Altus or Tom Steed Reservoir was not measured but probably was a small component of the water budget of the aquifer. Lakebed seepage flows were expected to vary seasonally with changes in lake stage, which generally was highest in the late spring months and lowest in the fall months. Annual lakebed seepage flows probably alternate between being aquifer inflows and outflows. The annual lakebed seepage of Lake Altus, for example, probably is an aquifer outflow during drought years when the lake stage is relatively low and an aquifer inflow when the lake is full. The annual lakebed seepage of Tom Steed Reservoir, however, probably is an aquifer inflow in most years because the lake stage is typically at a higher altitude than the surrounding aquifer materials. The net lakebed seepage of Lake Altus and Tom Steed Reservoir (combined) was assumed to be a negligible aquifer inflow (less than 1 percent of the conceptual-model water budget for the period 1980-2013).

\section{Springs and Seeps}

Few springs in alluvium and terrace deposits of the study area have been documented in published reports. Some reports, however, contain brief references to small springs, seeps, or perennial streams that are assumed to be springfed in the Quaternary alluvium and terrace deposits near the contact with underlying Permian bedrock. Steele and Barclay (1965) mentioned the presence of abundant small springs in the terrace deposits along the Elm Fork Red River northeast of
Mangum, Okla. (figs. 1 and 12). Burton (1965), in describing the alluvium and terrace deposits of Beckham County, mentioned that Spring Creek was the only perennial stream in that area. Barclay and Burton (1953) mentioned small springs along the eastern edge of the terrace deposits of Otter Creek just outside of the North Fork Red River aquifer study area. According to the available literature for the study area, small distributed springs and seeps and not large point discharges are most typical in the alluvium and terrace deposits of the North Fork Red River aquifer. Published flow rates for springs and seeps discharging from the North Fork Red River aquifer were not available, but they were expected to be a small part of the conceptual-model water budget; flows to springs and seeps were assumed to be proportional to base flow and were estimated to be no more than 10 percent of net streambed seepage for the study period.

\section{Saturated-Zone Evapotranspiration}

ET is the process by which water is transferred to the atmosphere directly through evaporation (or sublimation in the case of snow and ice) and indirectly through plant transpiration. Much of this process, however, occurs at or near the land surface as precipitation pools as surface water or infiltrates the soil unsaturated zone and becomes available to the plant root zone. These surface-water and unsaturatedzone components of ET were not considered to be a part of the conceptual model for the North Fork Red River aquifer because they occur before infiltrating precipitation has become groundwater recharge (reached the saturated zone). A supplementary component of ET, however, occurs in areas of the aquifer where the saturated zone intersects the plant root zone, most commonly in lower lying areas near streams; this component of ET (saturated-zone ET) was an important part of the conceptual-model water budget.

Rates of saturated-zone ET are difficult to estimate over a large area but should be roughly proportional to (1) the area where the saturated zone intersects the plant root zone, (2) the mean depth to groundwater in that area during the growing season, and (3) the mean rate of transpiration associated with the assemblage of plants in that area. The area where the saturated zone intersects the plant root zone probably is small (compared to the entire North Fork Red River aquifer area) and confined to the 107,200-acre area of active alluvium (Qal, fig. 12; Johnson and others, 2003; Stanley and Miller, 2004) along perennial or near-perennial streams. About 21 percent (22,300 acres) of the active alluvium area was classified as wetland (land area with frequently saturated or flooded soils) by the National Wetlands Inventory (U.S. Fish and Wildlife Service, 2015). The area where the saturated zone intersects the plant root zone probably is slightly larger than the area classified as wetland, however, because land areas do not have to be flooded to contribute to saturated-zone ET. About 25 percent (26,800 acres) of the active alluvium area (107,200 acres), therefore, was assumed to contribute to saturated-zone ET. Saturated-zone ET also was assumed to 
be proportional to and no greater than the potential ET minus the actual ET computed by using the Hargreaves and Samani (1985) method as described by Westenbroek and others (2010). This assumption resulted in the summed components of ET not exceeding the potential ET. The saturated-zone component of ET was assumed to be active for about half the year (182.5 days), greatest annually in wet and hot years, and greatest monthly in early summer (Scholl and others, 2005) when precipitation and temperature are above average (fig. 4).

By using the assumptions previously listed, groundwater outflow by saturated-zone ET could be estimated from daily water-level fluctuation data at wells with shallow depths to water according to methods of White (1932). Wells with these data were not available in the study area, but gage height data from selected streamgages (07301500, 07303400, 07304500, and 07305000; USGS, 2015a) showed daily declines in stream stage during summer low-flow conditions. These daily declines in stream stage (with rebounds at night) indicated that saturated-zone ET was an active process throughout the North Fork Red River aquifer, but the declines were too small to be accurately measured from the gage height data.

White (1932) estimated annual saturated-zone ET rates of $0.75-1.9 \mathrm{ft} / \mathrm{yr}$ for undisturbed salt grass cover in southwest Utah with a mean depth to water of 1-2 ft. Because ET rates in the high desert of Utah are likely to be greater than those in Oklahoma, an annual saturated-zone ET rate of about $1.0 \mathrm{ft} / \mathrm{yr}$ was assumed to be appropriate for the North Fork Red River. If about 25 percent (26,800 acres) of the active alluvium area $(107,200$ acres) had similar cover and depths to water, this assumed rate would correspond to an annual saturated-zone ET outflow of 26,800 acre-ft/yr (table 8 ). Annual saturatedzone ET was expected to be greater downgradient than upgradient from Lake Altus because the water table of the active alluvium tends to be shallower downgradient from Lake Altus (where gaining streams are more common, fig. 18). About 60 percent of the annual saturated-zone ET for the aquifer was allocated to the smaller downgradient portion of the aquifer (table 8), because that portion had mostly gaining reaches (and presumably more area with near-surface water table) according to the streambed-seepage data (fig. 18).

\section{Well Withdrawals, Water-Level Response, and Storage Change}

Mean annual well withdrawals were assumed to equal the mean annual reported groundwater use for the period 1980-2013, or 15,859 acre-ft/yr (table 4). About 84 percent of the annual well withdrawals for that period were from permitted wells upgradient from Lake Altus (mostly in Beckham and Greer Counties, fig. 8, table 8). Well withdrawals were greatest in dry and hot years because more water was required in those years to grow healthy crops. The water table generally falls during dry and hot years (especially during extended droughts) and rises during wet and cool years (fig. 3). The degree to which the water table fluctuates annually at a location is related in part to the volume of nearby ET and well withdrawals. For the study period 1980-2013, the OWRB (2015b) Mass Measurement Program recorded annual water-level measurements (usually in winter) from wells in the North Fork Red River aquifer. Those measurements show a general rise in water-level altitudes over the cooler and wetter early period (1980-2000) and a general decline in water-level altitudes over the hotter and drier late period (2001-2013) (figs. 20 and 3). Mean water levels for the period 1980-2013 fell $4.95 \mathrm{ft}$ in Beckham County, fell $5.85 \mathrm{ft}$ in Greer County, and rose $0.27 \mathrm{ft}$ in Kiowa County (fig. 20). Assuming an Sy of 0.12 and a mean water-level decline of about $3.5 \mathrm{ft}$ (the mean water-level change), the North Fork Red River aquifer lost about 209,000 acre-ft (6,150 acre-ft/yr) of storage during the period 1980-2013 (table 8).

\section{Conceptual Groundwater-Flow Model Water Budget}

The conceptual-model water budget (table 8) summarized mean water flows (fluxes) between each hydrologic boundary and the North Fork Red River aquifer for the period 19802013. Recharge accounts for most (95 percent) of the inflows to the North Fork Red River aquifer, and net streambed seepage accounts for most (59 percent) of the outflows from the North Fork Red River aquifer (fig. 16, table 8). The expected mean annual net change in groundwater storage $(6,150 \mathrm{acre}-\mathrm{ft} / \mathrm{yr})$ was reported as an aquifer inflow for later comparison with the calibrated numerical model water budget (fig. 16, table 8). Estimated inflows exceeded outflows upgradient from Lake Altus, and estimated outflows exceeded inflows downgradient from Lake Altus; therefore, inflows upgradient and outflows downgradient from Lake Altus may have been overestimated in the conceptual-model water budget. 

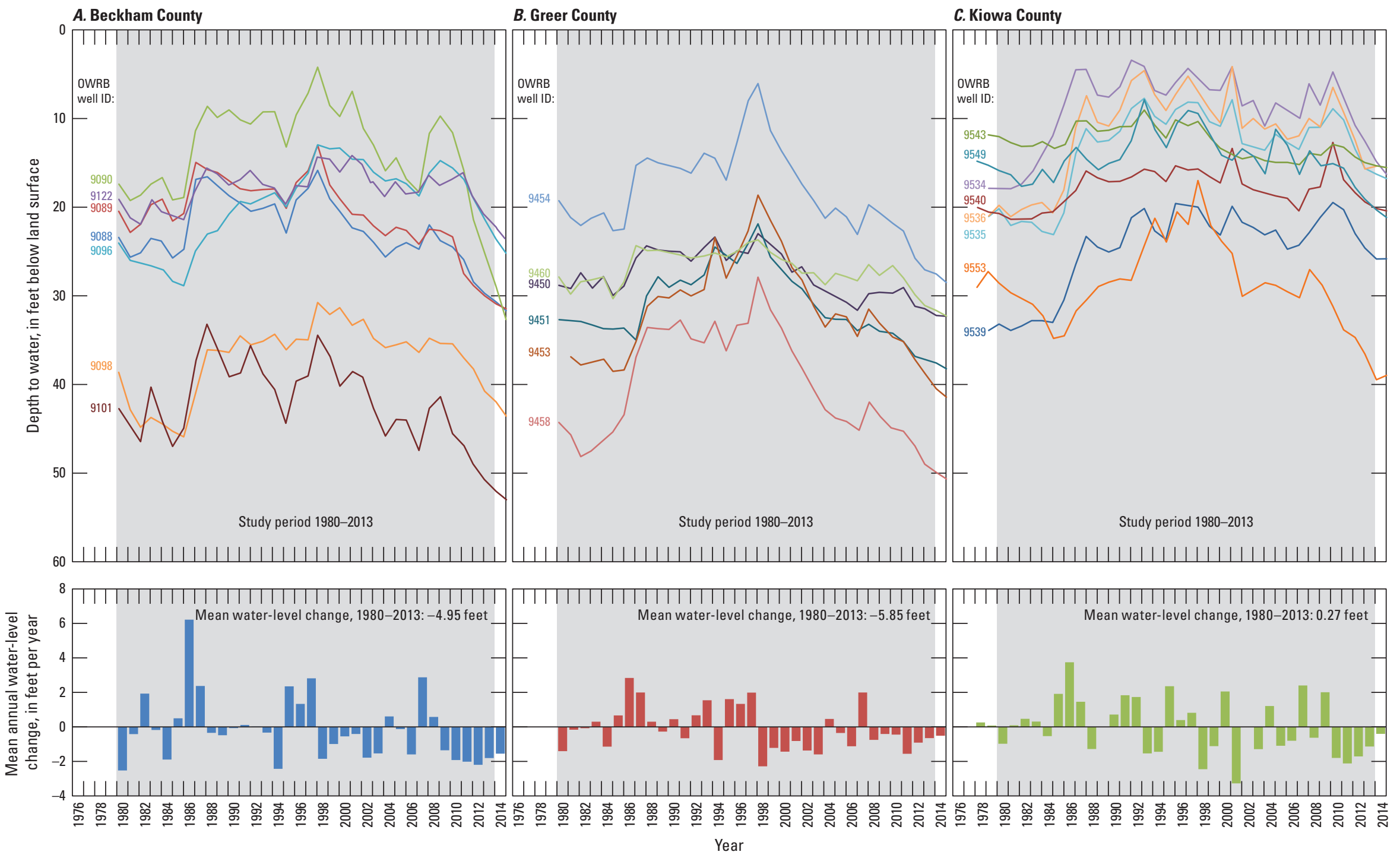

Figure 20. Annual water-level measurements and mean annual water-level change by county for Oklahoma Water Resources Board Mass Measurement Program wells completed in the North Fork Red River aquifer, 1978-2014. [OWRB well ID, Oklahoma Water Resources Board well identifier; data from Oklahoma Water Resources Board (2015b)] 


\section{Numerical Groundwater-Flow Model}

A finite-difference numerical model of the North Fork Red River aquifer was constructed by using MODFLOW-2005 (Harbaugh, 2005) with the Newton formulation solver (MODFLOW-NWT; Niswonger and others, 2011) for improved solution of problems involving drying and rewetting. In the modular design of MODFLOW, each hydrologic boundary of the conceptual model, such as streambed seepage, recharge, or well withdrawal, is included as a package that, when activated, adds new inflow and outflow terms to the groundwater-flow equation being solved. Data inputs for each package are specified in machine-readable text files. Model space is discretized into cells, and the cell size is the finest resolution at which spatially varying properties (such as landsurface altitude or hydraulic conductivity) may be represented and varied. Model time is discretized into time steps within stress periods. The stress period length is the finest resolution at which temporally varying inflows and outflows may be represented and varied, and the time step length is the finest length of time for which model outputs may be written. The numerical model represents hydraulic properties that appear reasonable on the basis of water-table-altitude, base-flow, and lake-stage observations, but may not be unique. Different combinations of model input parameters may result in an equally reasonable fit to the observations. The calibrated numerical groundwater-flow model inputs and outputs are available in Smith and others (2017).

\section{Spatial and Temporal Discretization}

The numerical model of the North Fork Red River aquifer had 385 rows, 460 columns, about 27,600 active cells of 886 by $886 \mathrm{ft}$ ( 270 by 270 meters), and 2 convertible layers. The cell size was chosen to minimize model-processing time while reasonably representing the variability of properties being modeled. The top layer (layer 1 ) represented the undifferentiated Quaternary alluvium and terrace deposits with variable thickness determined from the hydrogeologic framework, and the bottom layer (layer 2) represented the Permian bedrock with a nominal thickness of about $100 \mathrm{ft}$. The aquifer top altitude was multiplied by 1.001 in the numerical model to prevent confined aquifer conditions that occur when the simulated water-table altitude exceeds the aquifer top altitude.

The model active area (fig. 21) was created from the North Fork Red River aquifer extent (modified from the OWRB [2015b]), and expanded in some areas to ensure that each active cell was in connection with at least one other active cell. One terrace lobe in northern Beckham County was not included in the model active area because it was almost separated spatially and hydraulically from the rest of the North Fork Red River aquifer (fig. 21). Though the conceptual model divided the aquifer into areas upgradient and downgradient from Lake Altus, the numerical model described in this report combined both areas.
The numerical model was temporally discretized into 408 monthly transient stress periods (each with 2 time steps to improve model stability) representing the period 1980-2013. An initial steady-state stress period, in which the groundwaterflow equation had no storage component, represented mean annual inflows to and outflows from the aquifer and produced a solution that was used as the initial condition for subsequent transient stress periods. Though other units for length and time are used in this report, the numerical model was constructed by using units of meters and days.

\section{Simulation of Hydrologic Boundaries}

Hydrologic boundaries in the numerical model define where and how water may enter or leave the model (fig. 21) and include specified-head, specified-flux, and headdependent boundaries. A specified-head boundary was used to simulate lakebed seepage at Tom Steed Reservoir. Specified-flux boundaries were used to simulate recharge and well withdrawals. Head-dependent boundaries were used to simulate saturated-zone ET, lateral groundwater flow between adjacent alluvium and terrace deposits, springs and seeps, streambed seepage, and lakebed seepage at Lake Altus.

\section{Recharge and the Soil-Water-Balance Code}

Conceptual-model recharge to the North Fork Red River aquifer was spatially and temporally distributed for each month of the study period 1980-2013 by using the SWB code (Westenbroek and others, 2010). The SWB code uses a modified Thornthwaite and Mather (1957) soil-water-balance method on a gridded data structure to compute the daily amount of precipitation infiltration that exceeds the storage capacity of the plant root zone and the demand from plants for ET. The Hargreaves and Samani (1985) method for a reference latitude range of 34.5-35.5 degrees was used to compute ET. Land-cover and soil properties were used to estimate the amount of daily precipitation that entered the soil profile and the amount of daily precipitation runoff. Land-cover types (Multi-Resolution Land Characteristics Consortium, 2011) were used to assign runoff curve numbers and plant root-zone depths. The default SWB plant root-zone depths for shrubs/ range, grass/pasture, and crops (the dominant land-cover types overlying the aquifer, fig. 5) varied with soil texture and ranged from 2.0 to $3.6 \mathrm{ft}$ (Dripps, 2003; Westenbroek and others, 2010). Soil properties (available water capacity and hydrologic soil group) were derived from the Soil Survey Geographic database (SSURGO; Natural Resources Conservation Service, 2015). Digital elevation models (USGS, 2015b) were used to determine the surface-waterflow direction for each grid cell as described in Westenbroek and others (2010). The grid cell size used for the SWB code was 886 by $886 \mathrm{ft}$ (270 by 270 meters). The land-cover, soil, and altitude inputs were assumed to remain constant during the study period, but climate data inputs varied daily. Climate data inputs included interpolated grids of daily precipitation, 


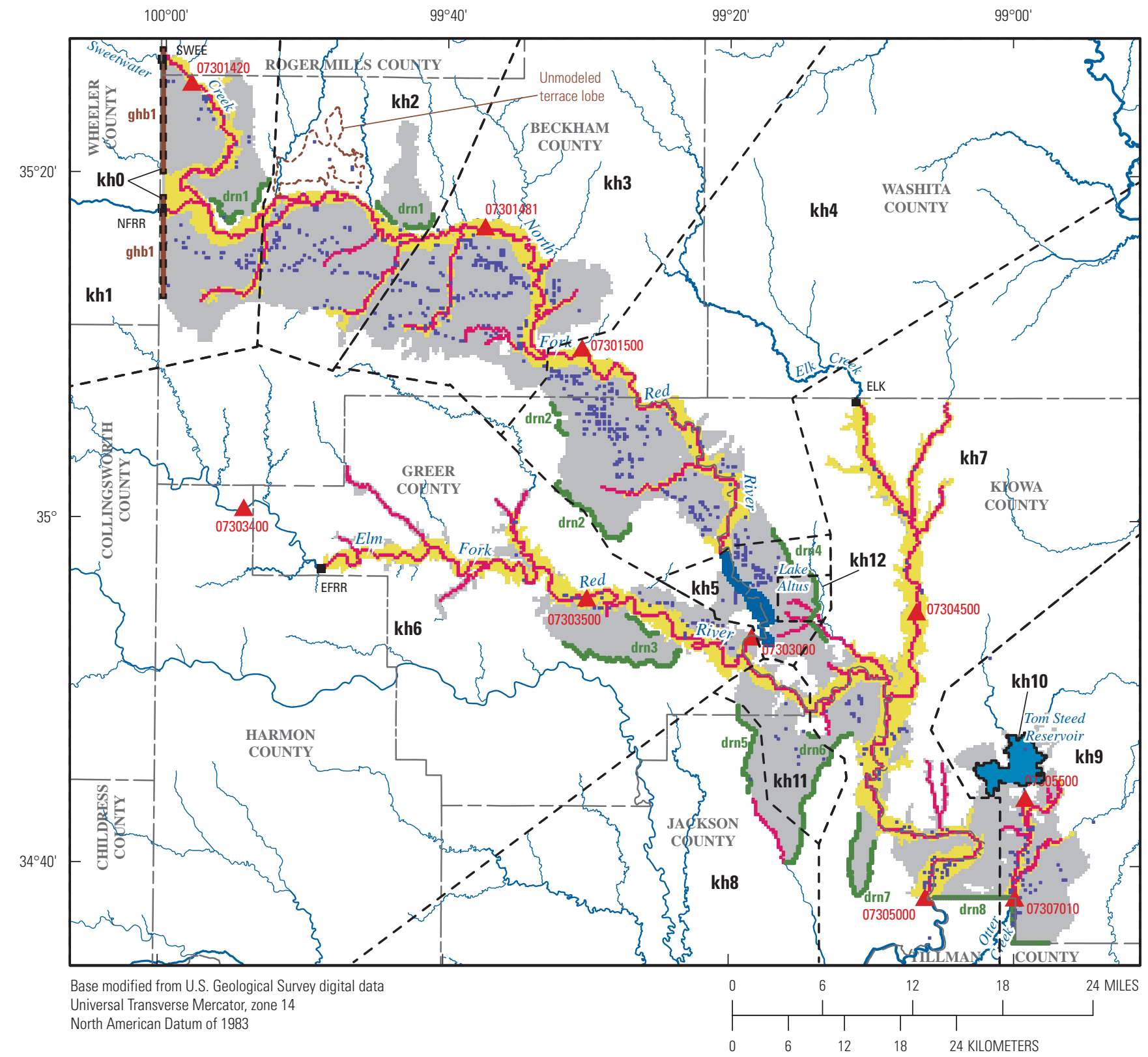

EXPLANATION

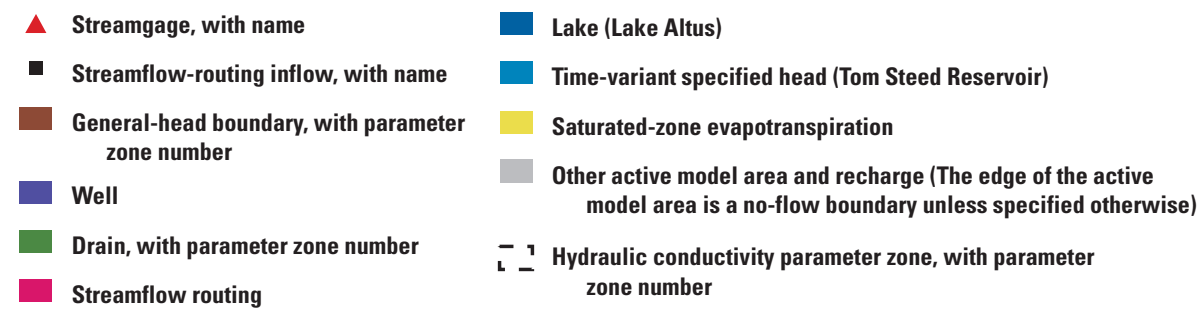

Figure 21. Active area, boundary conditions, and parameter zones for the numerical groundwater-flow model of the North Fork Red River aquifer, southwest Oklahoma. 
maximum temperature, and minimum temperature data from selected climate stations (National Climatic Data Center, 2015; Oklahoma Mesonet, 2015; table 1) in and near the study area (fig. 1).

The initial SWB-estimated mean annual recharge for the North Fork Red River aquifer study area for the period 19802013 was $1.38 \mathrm{in} / \mathrm{yr}$ (fig. 22) or 50 percent of the mean annual recharge (2.77 in/yr) estimated for the conceptual model. The initial SWB code used default plant root-zone depths that were developed for use in northern Wisconsin where crops are grown in soils overlying thick, loosely consolidated deposits of glacial till (Dripps, 2003). Plant root-zone depths in western Oklahoma were assumed to be less than those of Wisconsin, and the default plant root-zone depths were scaled to 70 percent to reduce the simulated interception of soil moisture and increase estimated recharge to the aquifer. With the scaled plant root-zone depths (1.4 to $2.5 \mathrm{ft}$ ), the SWBestimated mean annual recharge was $2.08 \mathrm{in} / \mathrm{yr}$ (fig. 22) or 75 percent of the mean annual recharge ( $2.77 \mathrm{in} / \mathrm{yr})$ estimated for the conceptual model. The plant root-zone depths were not decreased further to avoid unreasonable values. The SWBoutput monthly recharge grids were converted to mean daily recharge grids by dividing by the number of days per month; the mean daily recharge grids were used as precalibration numerical model inputs. The remaining difference ( $0.69 \mathrm{in} / \mathrm{yr})$ between the SWB-estimated mean annual recharge (2.08 in/ yr) and the conceptual-model-estimated mean annual recharge (2.77 in/yr) was gained by scaling the SWB monthly recharge grids with multipliers during the numerical model calibration.

The minimum and maximum SWB-estimated annual recharge amounts for the period 1980-2013 were about $0.2 \mathrm{in}$. (2012) and 4.7 in. (1986), respectively (fig. 22). Spatially, recharge was greatest in areas of active alluvium along the North Fork Red River and in selected areas of the terrace deposits (Qtd) where windblown sand (dune) deposits were abundant (figs. 12 and 23). Mean monthly recharge for the period 1980-2013 was greatest in May and June, when precipitation was greatest (fig. 4). Mean monthly recharge normalized by the mean monthly precipitation was greatest in the winter months, when ET was at a minimum.

\section{Lateral Groundwater Flows}

Lateral groundwater flows between the North Fork Red River aquifer and adjoining alluvium and terrace deposits in Texas were simulated by using the General-Head Boundary (GHB) package (Harbaugh and others, 2000) (fig. 21). The flow to or from a GHB cell is the product of the GHB conductance and the difference between the water-table altitude and the GHB altitude. The GHB conductance was roughly equivalent to the hydraulic conductivity of the aquifer multiplied by the numerical model cell size. Based on the potentiometric surfaces of the North Fork Red River aquifer (fig. 14) and the Tillman Terrace aquifer (Osborn, 2002; Barclay and Burton, 1953), lateral groundwater flows across the Tillman County border were expected to always be outflows. Therefore, lateral groundwater outflows from the North Fork Red River aquifer to the Tillman Terrace aquifer were simulated by using the Drain package (Harbaugh and others, 2000) (drn8, fig. 21). The drain conductance was roughly equivalent to the hydraulic conductivity of the aquifer multiplied by the numerical model cell size. Flow between the aquifer and drain cells functions the same way as the GHB package, except that there is no drain flow when the watertable altitude is less than the drain altitude.

\section{Streams}

Named streams (Horizon Systems Corporation, 2015) were simulated by using the Streamflow-Routing package, version 2 (SFR) (Niswonger and Prudic, 2005) (fig. 21). Only base flow was simulated in SFR streams. Inflows for SFR streams include base flows routed from upstream segments, specified inflows (base flows) from tributary streams, and streambed seepage from the water table; SFR outflows include base flows routed downstream and streambed seepage to the water table. The SFR package exchanges flow between the aquifer and the stream according to Darcy's Law (Darcy, 1856); the flow exchanged between the aquifer and the stream is the product of the streambed conductance and the difference between the water-table altitude and the stream stage.

Simulated base flows are calculated for each part of the stream contained in a model cell, known as reaches, until the end of a segment, or group of cells with uniform or linear hydraulic properties, is reached during each time step. Computation of flows repeats in a downstream direction until flows are routed out of the numerical model active area.

All SFR stream segments were assigned an assumed streambed thickness of $6.6 \mathrm{ft}$ and an estimated streambed conductivity of $16.4 \mathrm{ft} / \mathrm{d}$. This streambed conductivity value was within the expected range of hydraulic conductivity determined from the aquifer hydrogeologic framework and was about 26 percent greater than the streambed conductivity used for a numerical model of the Beaver-North Canadian River alluvial aquifer (Ryter and Correll, 2016). The channel widths of stream segments were estimated from 2013 aerial photographs (Natural Resources Conservation Service, 2015) and ranged from 6.6 to $197 \mathrm{ft}$, gradually increasing downstream. The streambed altitude of each stream segment was derived from 10-meter DEMs (USGS, 2015b). Monthly base-flow inflows at the boundary of the numerical model active area were specified for Sweetwater Creek (SWEE), North Fork Red River (NFRR), Elk Creek (ELK), and Elm Fork Red River (EFRR) (fig. 21). These specified inflows were assigned based on distance-weighted flow between the nearest upstream and downstream streamgages. For periods when streamgage data were not available, mean monthly baseflow values averaged over the available period of record were used as specified inflows. All other streams were assumed to have no specified inflows at the boundary of the numerical 


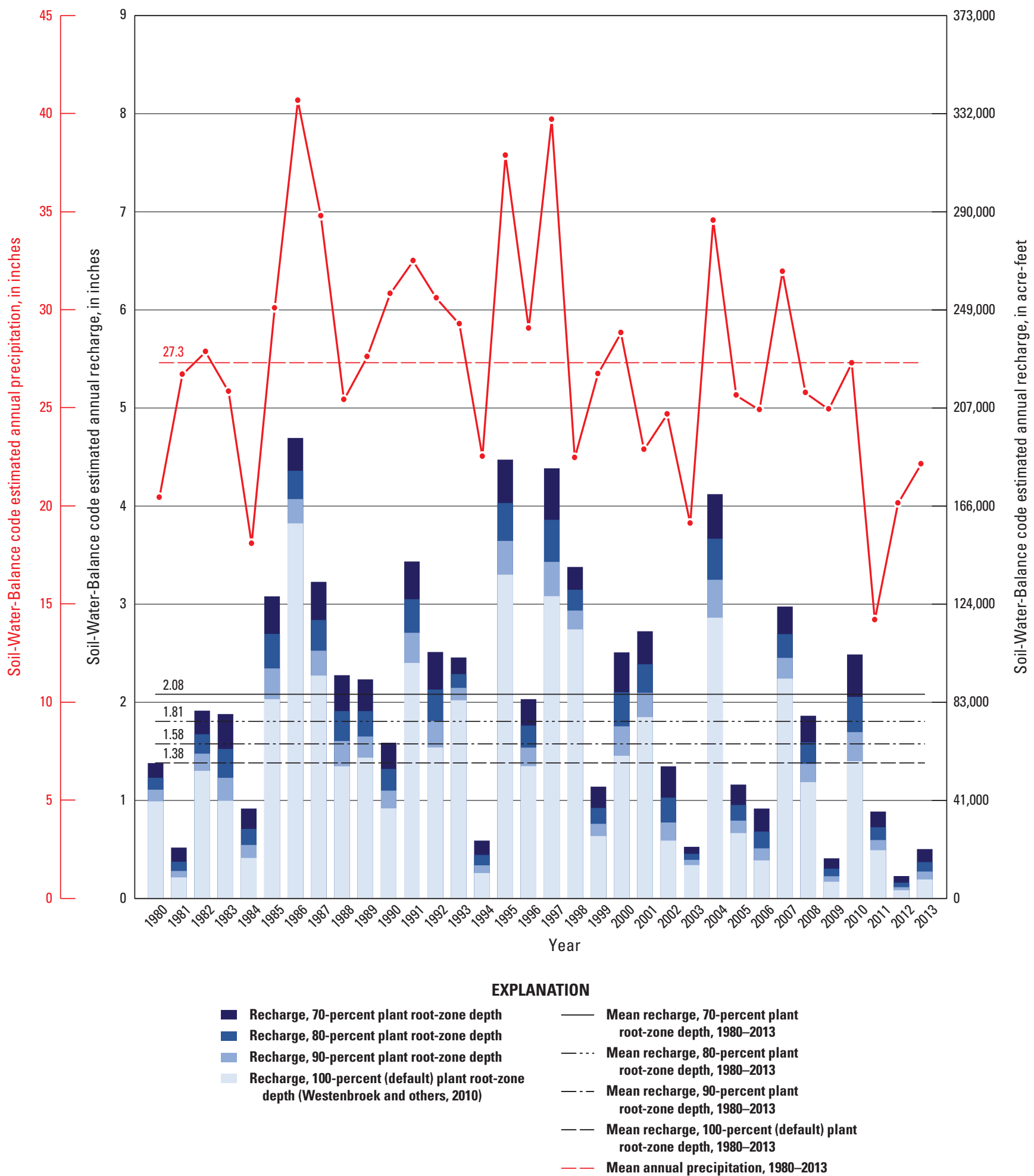

Figure 22. Annual precipitation and annual groundwater recharge computed by using the Soil-Water-Balance code (Westenbroek and others, 2010) for the North Fork Red River aquifer, 1980-2013. 


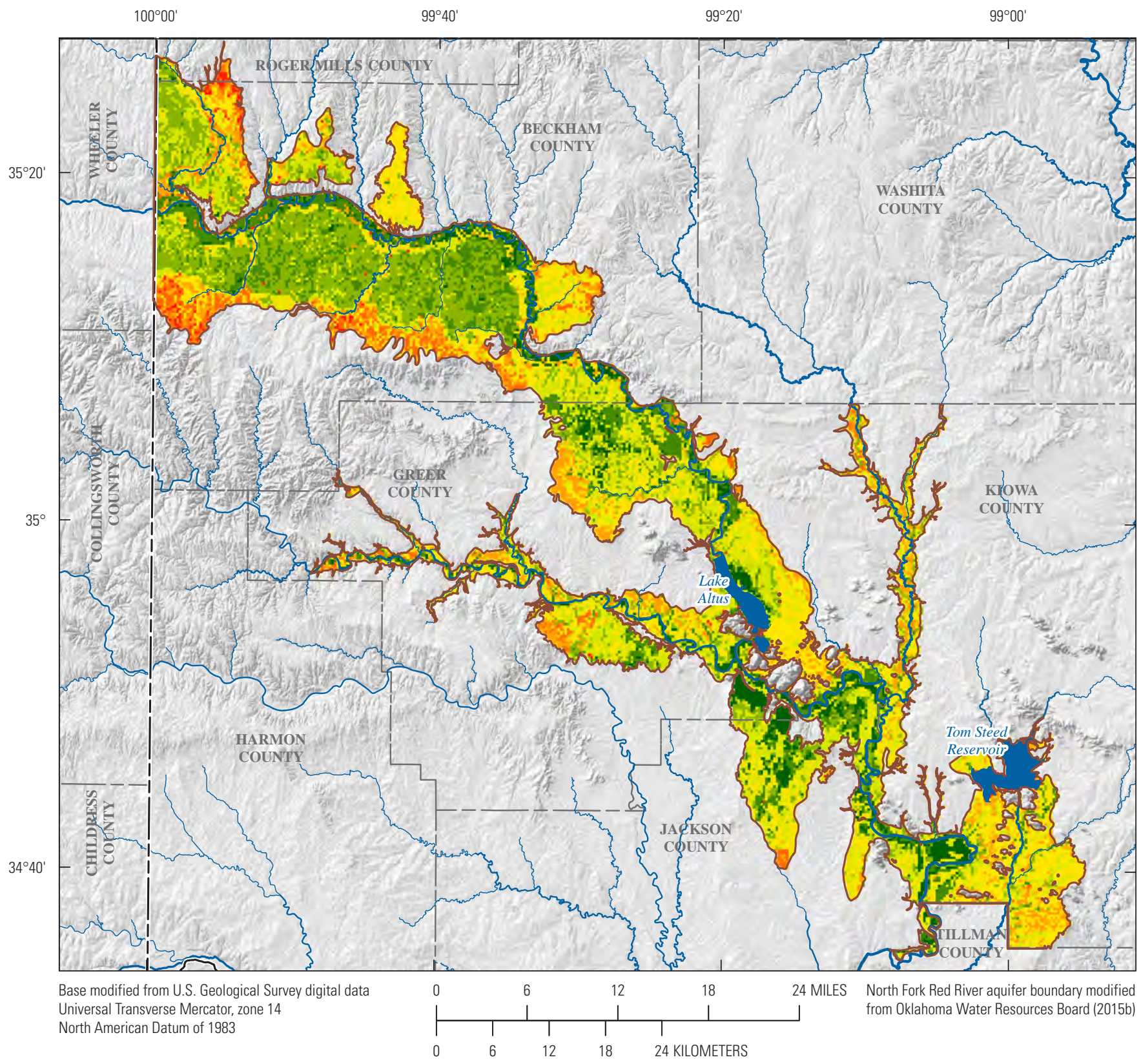

EXPLANATION

North Fork Red River aquifer boundary

Spatially distributed mean annual recharge, in inches, 1980-2013, from the Soil-Water-Balance code;

recharge was scaled upward (increased) for use in the numerical groundwater-flow model

$\square 0.00$ to $0.30 \quad \square 1.41$ to 2.10

$\square 0.31$ to $0.50 \quad \square 2.11$ to 3.00

$\square 0.51$ to $0.75 \quad \square 3.01$ to 5.00

$\square 0.76$ to $1.40 \quad \square 5.01$ to 16.75

Figure 23. Mean annual groundwater recharge computed by using the Soil-Water-Balance code (Westenbroek and others, 2010) for the North Fork Red River aquifer, 1980-2013. 
Hydrogeology and Simulated Groundwater Flow and Availability in the North Fork Red River Aquifer, Southwest Okla.

model active area. Withdrawals from Lake Altus for irrigation (LAID, permit 19390023) and public supply (city of Altus, permit 19260006) were simulated in the model. Permitted diversions from streams were not simulated; although these diversions were allocated about 5,000 acre-ft/yr by OWRB (2015b), the diversions were mostly on small intermittent streams (USGS, 2015b) with minimal to no base flow for much of the year and were considered a minor component in the overall water budget for the study area.

\section{Lakes}

Tom Steed Reservoir was simulated as a specified-head boundary by using the Time-Variant Specified-Head package (fig. 21). Simulated lake stage was varied monthly according to historical lake-stage records (U.S. Bureau of Reclamation, 2015c). Monthly lakebed seepage for Tom Steed Reservoir was governed by the hydraulic conductivity of the aquifer.

Lake Altus was simulated by using the Lake package (Merritt and Konikow, 2000; Niswonger and Prudic, 2005) (fig. 21). Lake Altus bathymetry and stage-storage relation data were obtained from a 2007 sedimentation survey (U.S. Bureau of Reclamation, 2014) and the relation was assumed to remain the same through all simulations. Lakebed seepage at Lake Altus was governed by a lakebed leakance factor of 1.3 feet per day per foot. Other data for components of the Lake Altus water budget varied monthly and were obtained from a variety of sources. Estimated lake-surface precipitation and evaporation data were supplied by the U.S. Army Corps of Engineers (2015b) and Andy Kmetz (U.S. Army Corps of Engineers, written commun., September 15, 2014). Lakewithdrawal volumes for irrigation and public-supply use were supplied by the U.S. Bureau of Reclamation (2015b). Floodcontrol releases were estimated by averaging release data from the U.S. Bureau of Reclamation (2015b) and North Fork Red River streamflows at the Lugert streamgage (07303000, fig. 1; USGS, 2015a). Flood-control releases from Lake Altus were not routed to the downstream SFR segments of the North Fork Red River. Surface-water inflows to Lake Altus were routed as SFR-simulated base flows from the North Fork Red River where it enters the lake (fig. 21). Runoff inflows to Lake Altus were assumed to equal the BFI-estimated runoff component of streamflow at the Carter streamgage (07301500). The Lake package simulation of Lake Altus is the only part of the numerical model that includes the runoff component of streamflow; inclusion of runoff was necessary to simulate the correct lake stage.

\section{Springs and Seeps}

Some groundwater was expected to leave the North Fork Red River aquifer through distributed spring and seep discharge areas where terrace deposits extend across major groundwater divides. These spring and seep discharge areas (drn1-drn7; fig. 21) were simulated by using the Drain package. The flow from the aquifer at a drain cell is the product of the drain conductance and the difference between the water-table altitude and the drain altitude. Flow between the aquifer and drain cells functions the same way as the GHB package, except that there is no drain flow when the water-table altitude is less than the drain altitude. The drain conductance varied by location but was roughly equivalent to the hydraulic conductivity of the aquifer multiplied by the numerical model cell size.

\section{Saturated-Zone Evapotranspiration}

Saturated-zone ET was simulated by using the Evapotranspiration package (Harbaugh and others, 2000) and was limited to the active alluvium areas near streams in the North Fork Red River aquifer (fig. 21). Maximum rates of saturated-zone ET were assumed to be proportional to and no greater than the potential minus actual ET as computed by the SWB code. The ET extinction depth, or the depth below land surface at which the saturated zone becomes inaccessible to plants, was set to $2.6 \mathrm{ft}$, which was about the area-weighted mean plant root-zone depth specified in the SWB code.

\section{Well Withdrawals}

Well withdrawals were simulated by using the Well package (Harbaugh and others, 2000). Annual reported groundwater use for each permit was distributed evenly to all of the wells attached to that permit (OWRB, 2015b). These annual well withdrawals then were distributed into monthly well withdrawals by using monthly demand distributions (fig. 24) for Oklahoma Comprehensive Water Plan watermanagement planning basin 36 (fig. 2) (OWRB, 2012a). Annual irrigation well withdrawals were multiplied by the monthly irrigation demand (as a percentage of annual groundwater withdrawals), and annual public-supply well withdrawals were multiplied by the monthly public-supply demand (as a percentage of annual groundwater withdrawals). Annual well withdrawals for other purposes were distributed evenly to all months of the year. Domestic withdrawals, which are not regulated or reported by the OWRB, were not simulated; these withdrawals were expected to be a minor component of total withdrawals because the rural population of the study area was small and most of the study area was served by rural or municipal public water-supply systems (OWRB, 1998).

Groups of wells attached to a single permit were not allowed to exceed (cumulatively) the annual permitted amount. Individual well withdrawals greater than 405 acre-ft/yr (equivalent to a continuous annual pumping rate of $250 \mathrm{gal} / \mathrm{min}$ ) were considered unreasonable for this aquifer and were reduced to that threshold value to avoid instability in the numerical model. Steady-state well withdrawals were determined as the mean of withdrawals during the study period. 


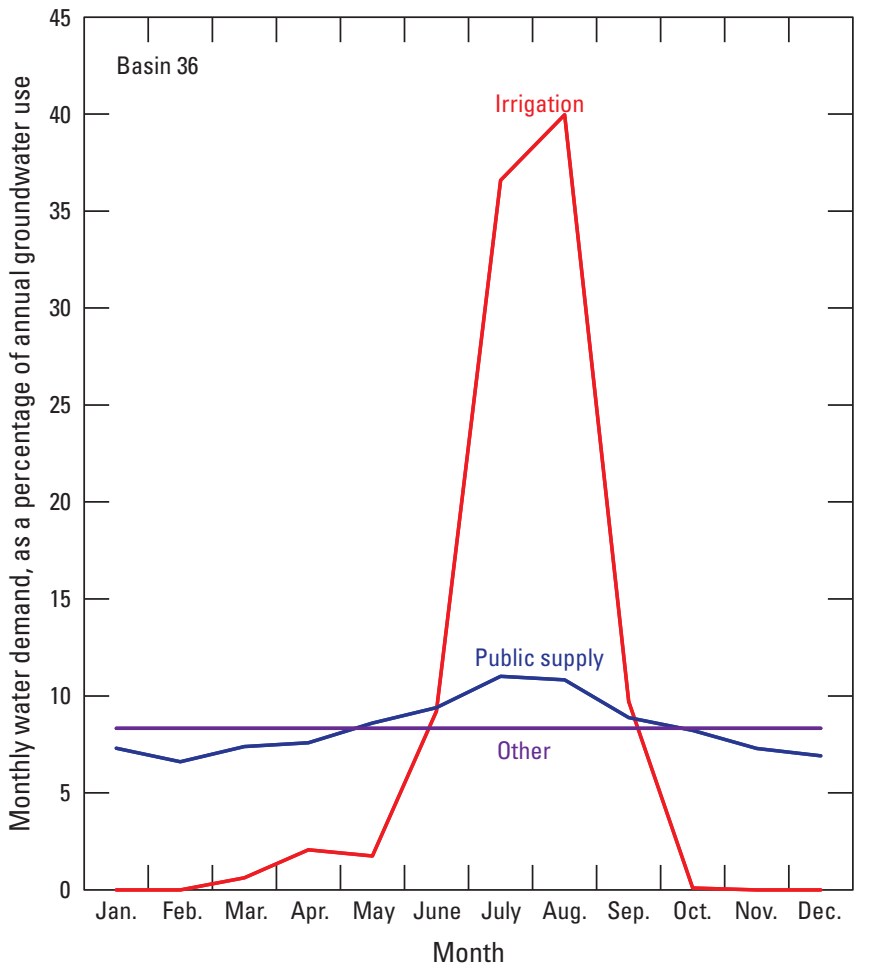

Figure 24. Monthly water demand by groundwater-use type from the North Fork Red River aquifer, 1980-2013. Modified from Oklahoma Water Resources Board (2012a).

\section{Calibration}

Model calibration is the process of systematically changing initial model input values (within reasonable limits) to improve the fit between model-simulated data and observed data (calibration targets). The preferred calibration results (1) minimize the differences between the simulated and observed data (residuals) and (2) conform to the conceptual model. The calibration process for the numerical model included manual adjustment of selected model inputs (parameters) followed by automated adjustment of parameters by using the parameter estimation code PEST (Doherty, 2010). The automated calibration approach used singular value decomposition-assist (Doherty, 2010) to reduce run times associated with the calibration of a large number of parameters.
For the North Fork Red River numerical model automated calibration, six parameter groups representing a total of 348 parameters were defined. These parameter groups included 323 parameters for recharge, 14 parameters for Kh (13 zone multipliers [kh0-kh12; fig. 21] and 1 array multiplier), 8 parameters for drain conductance, and 1 parameter each for GHB conductance, ET, and Sy. The locations of the Kh, drain conductance, and GHB conductance parameter zones are shown in figure 21 . The recharge parameter group was composed of temporal recharge-rate multipliers for SWB-determined recharge in 323 of the 409 stress periods; the remaining 86 stress periods had negligible recharge. Kh values were grouped into 13 parameter zones (fig. 21), with each zone representing an area where $\mathrm{Kh}$ was thought to be relatively uniform. A rate multiplier was specified for each Kh zone and adjusted during calibration. The GHB and drain conductances were adjusted until the water table in the simulated alluvium and terrace locations approached the observed water table. An array multiplier was used to adjust the saturated-zone ET rates and was applied uniformly to all ET arrays for each stress period.

\section{Calibration Targets}

The numerical model was calibrated to water-tablealtitude observations at selected wells, monthly base flow at selected streamgages, net streambed seepage as estimated for the conceptual model, and Lake Altus stage (table 9). Prior to the calibration process, weights were used to account for data quality. Weights were assigned as the inverse of the standard deviation, and the weighted calibration targets were placed into four observation groups on the basis of observation type (table 9). The objective function, or squared sum of the weighted residuals, provides a measure of the fit between observed and simulated data. The observation group contributions to the objective function (table 9) were adjusted prior to the start of the calibration process to ensure a balance between each group so that no single observation group dominated the calibration process. The base-flow observation group was assigned the greatest contribution to the objective function (37 percent) because those measurements were thought to have the greatest accuracy and temporal coverage during the model period 1980-2013. The water-table-altitude observation group was assigned the second greatest contribution to the objective function (30 percent) because those measurements were thought to have the greatest spatial coverage during the model period 1980-2013. 
Table 9. Observation group contribution to the objective function for the automated calibration of the numerical groundwater-flow model of the North Fork Red River aquifer, 1980-2013.

[ft, feet; $\mathrm{ft}^{3} / \mathrm{s}$, cubic feet per second]

\begin{tabular}{llccc}
\hline \multirow{2}{*}{ Observation group } & \multicolumn{1}{c}{ Source } & $\begin{array}{c}\text { Number of } \\
\text { observations }\end{array}$ & $\begin{array}{c}\text { Group } \\
\text { contribution } \\
\text { (percent) }\end{array}$ & $\begin{array}{c}\text { 0bjective } \\
\text { function }\end{array}$ \\
\hline Water-table altitude & Water-table-altitude observations (Oklahoma Water Resources & 11,695 & 30 & 29,122 \\
\multirow{2}{*}{ Base flow } & Board, 2015b; U.S. Geological Survey, 2015a) & & & 8,540 \\
& Sweetwater streamgage (07301420; U.S. Geological Survey, 2015a) & 331 & 4 & 19,849 \\
& Carter streamgage (07301500; U.S. Geological Survey, 2015a) & 408 & 20 & 8,332 \\
\multirow{2}{*}{$\begin{array}{l}\text { Lake stage } \\
\text { Net streambed } \\
\text { seepage }\end{array}$} & Headrick streamgage (07305000; U.S. Geological Survey, 2015a) & 408 & 8 & 21,556 \\
\hline & Lake Altus stage (U.S. Bureau of Reclamation, 2015b) & 408 & 22 & 10,818 \\
\hline
\end{tabular}

${ }^{1}$ Of the 2,079 water-table-altitude observations (table 11), 384 were removed from the automated calibration because they showed little sensitivity to any parameter changes.

\section{Water-Table-Altitude Observations}

The automated numerical model calibration used 1,695 water-table-altitude observations at 150 wells in the study area (table 1); 384 of the 2,079 water-tablealtitude observations were removed from the automated calibration because they showed little sensitivity to any parameter changes. The majority of the water-table-altitude observations were annual measurements from OWRB (2015b) Mass Measurement Program wells, and those wells were distributed across most of the aquifer (some locations shown on fig. 1). Supplemental water-table-altitude observations were obtained from the USGS (2015a) (locations not shown on fig. 1). Most years in the study period 1980-2013 had greater than 60 total water-table-altitude observations (fig. 25A), but the number of water-table-altitude observations in each year generally decreased over time. Water-tablealtitude observations during February-March 1980 were used as calibration targets for the steady-state stress period, and water-table-altitude observations during February-March 2014 were used as December 2013 calibration targets. All watertable-altitude observations were originally collected as depthto-water measurements; water-table altitudes were calculated by subtracting the measured depth to water from the landsurface altitude specified by a 10-meter DEM (USGS, 2015b).

Weights were determined based on the location and altitude accuracy of each water-table-altitude observation well using methods of Clark and Hart (2009) and Hill and Tiedeman (2007). The location and altitude accuracy values recorded in the NWIS (USGS, 2015a) and OWRB (2015b) databases are based on the measurement methods, typically either a Global Positioning System or a topographic map. The recorded location accuracy was between 0.1 and 9.2 arcseconds for water-table-altitude observation wells completed in the North Fork Red River aquifer. A radius equal to the location accuracy was created for each observation well, and the standard deviation of DEM land-surface altitudes in that radius was calculated. The standard deviation of the altitude accuracy was calculated by dividing half of the altitude accuracy code (in feet) by the critical value of a 95-percent confidence interval (Hill and Tiedeman, 2007). Standard deviations for the water-table-altitude observation wells ranged from 0.13 to $15.9 \mathrm{ft}$ with a mean of $3.1 \mathrm{ft}$.

\section{Base Flow and Net Streambed Seepage}

The numerical model was manually calibrated to baseflow observations at six streamgages (fig. 25B), but the automated calibration only used base-flow observations from three streamgages that had long periods of record covering most of the model period (table 9). Monthly base-flow observations were available for each monthly stress period at the Carter (07301500) and Headrick (07305000) streamgages and for each monthly stress period since May 1986 at the Sweetwater streamgage (07301420) (fig. 25B, table 1). These 1,147 monthly base-flow observations were used as transient calibration targets. Monthly base-flow observations were available for shorter periods at other streamgages, but those observations were not used in the automated numerical model calibration. The base-flow observation uncertainty was determined by using the accuracy code for the streamflow data at each streamgage in NWIS. The majority of the field streamflow measurements during the transient period received a "fair" rating in NWIS, which corresponds to a 95-percent confidence interval of \pm 15 percent of true streamflow (USGS, 2015c). The standard deviation for the base-flow observations at each streamgage was then calculated as 15 percent of the base flow, divided by the critical value of a 95 -percent confidence interval. 

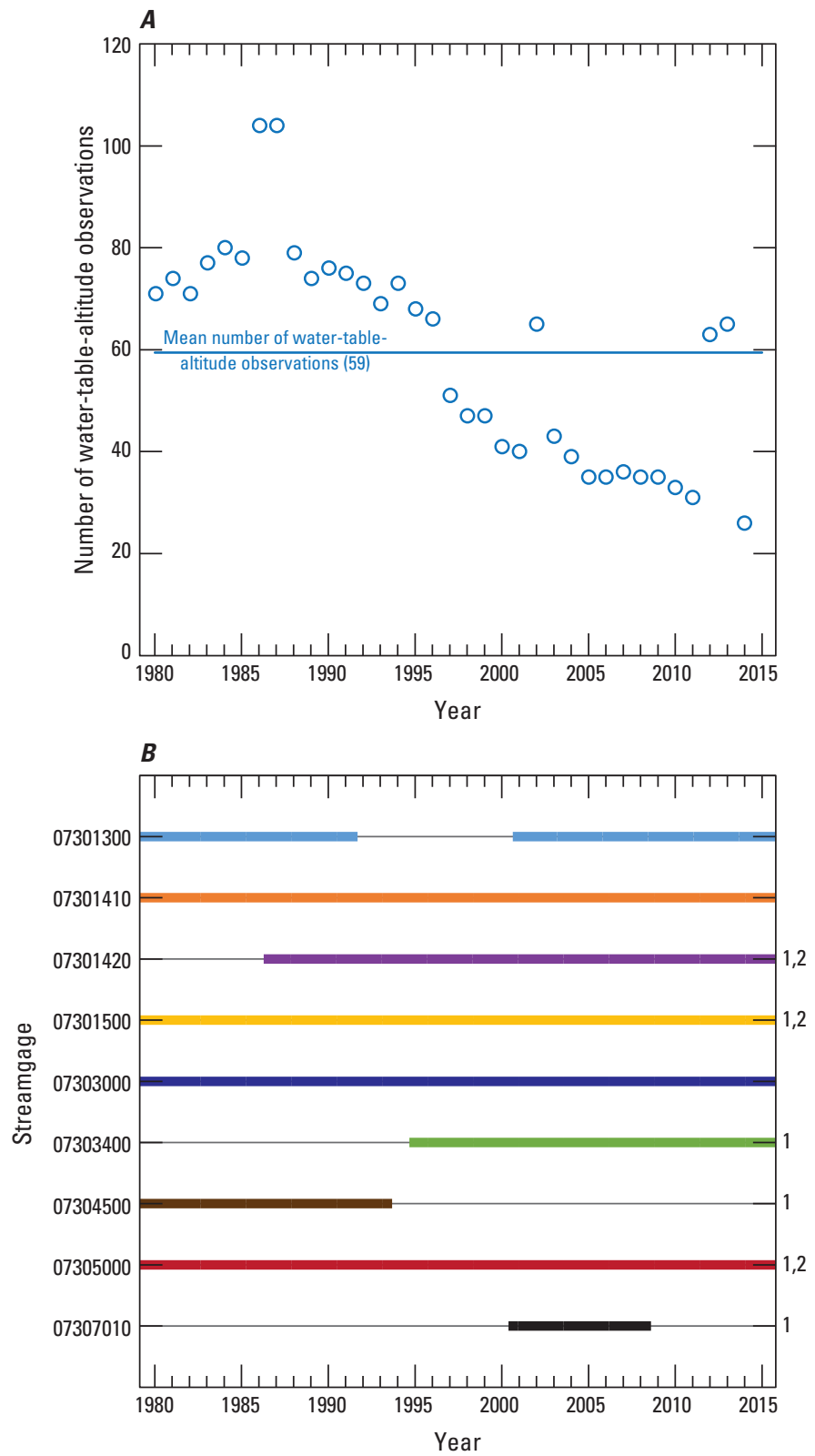

Net streambed seepage upgradient from Lake Altus (table 8) also was used as a calibration target. The simulated net streambed seepage upgradient from Lake Altus was determined as the sum of the "Flow to Aquifer" column in the SFR flow file divided by the 408 monthly stress periods for the transient simulation (Smith and others, 2017). Weights for the streambed seepage were assigned by using methods from Hill and Tiedeman (2007) and were given a 95-percent confidence interval of \pm 15 percent of actual flow. The standard deviations and variance of the base flow at each streamgage during the transient period were calculated, and the upstream and downstream streamgage variances were summed to produce a standard deviation for the streambed seepage.

\section{Lake Altus Stage}

Lake Altus stage observations from the U.S. Bureau of Reclamation (2015b) were referenced to the National Geodetic Vertical Datum of 1929; therefore, a conversion factor of $0.5 \mathrm{ft}$ (National Oceanic and Atmospheric Administration, 2015) was added to reference these observations to the North American Vertical Datum of 1988 (NAVD 88). At normalpool stage (1,559.5 ft above NAVD 88), Lake Altus storage was about 134,000 acre-ft; at inactive-pool stage $(1,518.0 \mathrm{ft}$ above NAVD 88), Lake Altus storage was about 1,600 acre-ft (U.S. Bureau of Reclamation, 2014). Because the inactivepool storage was relatively small, it was not removed from estimates of Lake Altus storage used in this report.

\section{Calibration Results}

Calibration results were evaluated on the basis of the reduction of residuals and the fit of the calibrated numerical model water-budget components to those of the conceptualmodel water budget. Residuals were calculated as observed minus simulated values; positive residuals indicate lower simulated than observed values, and negative residuals indicate higher simulated than observed values.

\section{Simulated Aquifer Thickness and Saturated Thickness}

The simulated mean aquifer thickness was $71 \mathrm{ft}$, and the simulated mean aquifer saturated thickness at the end of the simulation was $38 \mathrm{ft}$ (table 10). The simulated maximum aquifer thickness was $326 \mathrm{ft}$ and was located in cells adjacent to mountains downgradient from Lake Altus (table 10). These cells represent colluvium materials that were considered to be part of the aquifer, but probably have minimal saturated thickness. The large aquifer thickness in those cells was an artifact of the steep slope of the mountains downgradient from Lake Altus combined with the 886-by-886- $\mathrm{ft}$ model cell size, which resulted in overestimation of the aquifer top altitude. The simulated maximum aquifer thickness of $267 \mathrm{ft}$ upgradient from Lake Altus (in central Beckham County) is more representative of the actual maximum aquifer thickness (table 10). 
Table 10. Statistical summary of aquifer thickness, saturated thickness, and hydraulic properties for the calibrated numerical groundwater-flow model of the North Fork Red River aquifer, 1980-2013.

$\left[\mathrm{mi}^{2}\right.$, square miles; ft, feet; ft/d, feet per day]

\begin{tabular}{|c|c|c|c|c|c|c|c|c|c|c|c|c|}
\hline Aquifer part & $\begin{array}{l}\text { Cell } \\
\text { count }\end{array}$ & $\begin{array}{l}\text { Area } \\
\left(\mathrm{mi}^{2}\right)\end{array}$ & \multicolumn{3}{|c|}{$\begin{array}{c}\text { Aquifer } \\
\text { thickness } \\
\text { (ft) }\end{array}$} & \multicolumn{3}{|c|}{$\begin{array}{c}\text { Aquifer } \\
\text { saturated thickness } \\
\text { (ft) }\end{array}$} & \multicolumn{3}{|c|}{$\begin{array}{c}\text { Hydraulic } \\
\text { conductivity } \\
\text { (ft/d) }\end{array}$} & $\begin{array}{l}\text { Specific } \\
\text { yield }\end{array}$ \\
\hline $\begin{array}{l}\text { Upgradient } \\
\text { from Lake } \\
\text { Altus }\end{array}$ & 15,075 & 424 & 31 & 79 & 267 & 0 & 41 & 183 & 8.4 & 36.5 & 114 & 0.12 \\
\hline $\begin{array}{l}\text { Downgradient } \\
\text { from Lake } \\
\text { Altus }\end{array}$ & 12,547 & 353 & 31 & 62 & ${ }^{13} 326$ & 0 & 35 & 82 & 16.1 & 57.8 & 119 & 0.12 \\
\hline $\begin{array}{l}\text { Total } \\
\text { (weighted) }\end{array}$ & 27,622 & 777 & 31 & 71 & ${ }^{13} 326$ & 0 & 38 & 183 & 8.4 & 46.2 & 119 & 0.12 \\
\hline
\end{tabular}

${ }^{1}$ The calibrated maximum aquifer thickness downgradient from Lake Altus is found in cells adjacent to mountains. The large aquifer thickness in those cells was an artifact of the steep slope of the mountains downgradient from Lake Altus combined with the 886-ft-by-886-ft model cell size, which resulted in overestimation of the aquifer-top altitude. The calibrated maximum aquifer thickness of $267 \mathrm{ft}$ upgradient from Lake Altus (in cells of central Beckham County) is more representative of the actual maximum aquifer thickness.

\section{Comparison of Simulated and Observed Values}

Simulated and observed water levels were compared by using standard graphs (fig. 26) and statistical summaries (table 11). The combined mean residual for steady-state and transient simulations was $-0.6 \mathrm{ft}$, indicating that, on average, simulated water levels were slightly higher than observed water levels. The combined water-table altitude root-meansquare error (RMSE) was $11.8 \mathrm{ft}$, and 75 percent of residuals were within $\pm 13.9 \mathrm{ft}$ of observed measurements (table 11). The simulated water-table relief was $799 \mathrm{ft}(2,110-1,311 \mathrm{ft})$, and the combined RMSE as a percentage of this water-table relief was 1.5 percent. These error statistics were about double those for Reach I of the Canadian River alluvial aquifer (Ellis and others, 2017); however, the North Fork Red River aquifer had a more complex geologic setting and much greater well withdrawals than the Canadian River alluvial aquifer. 

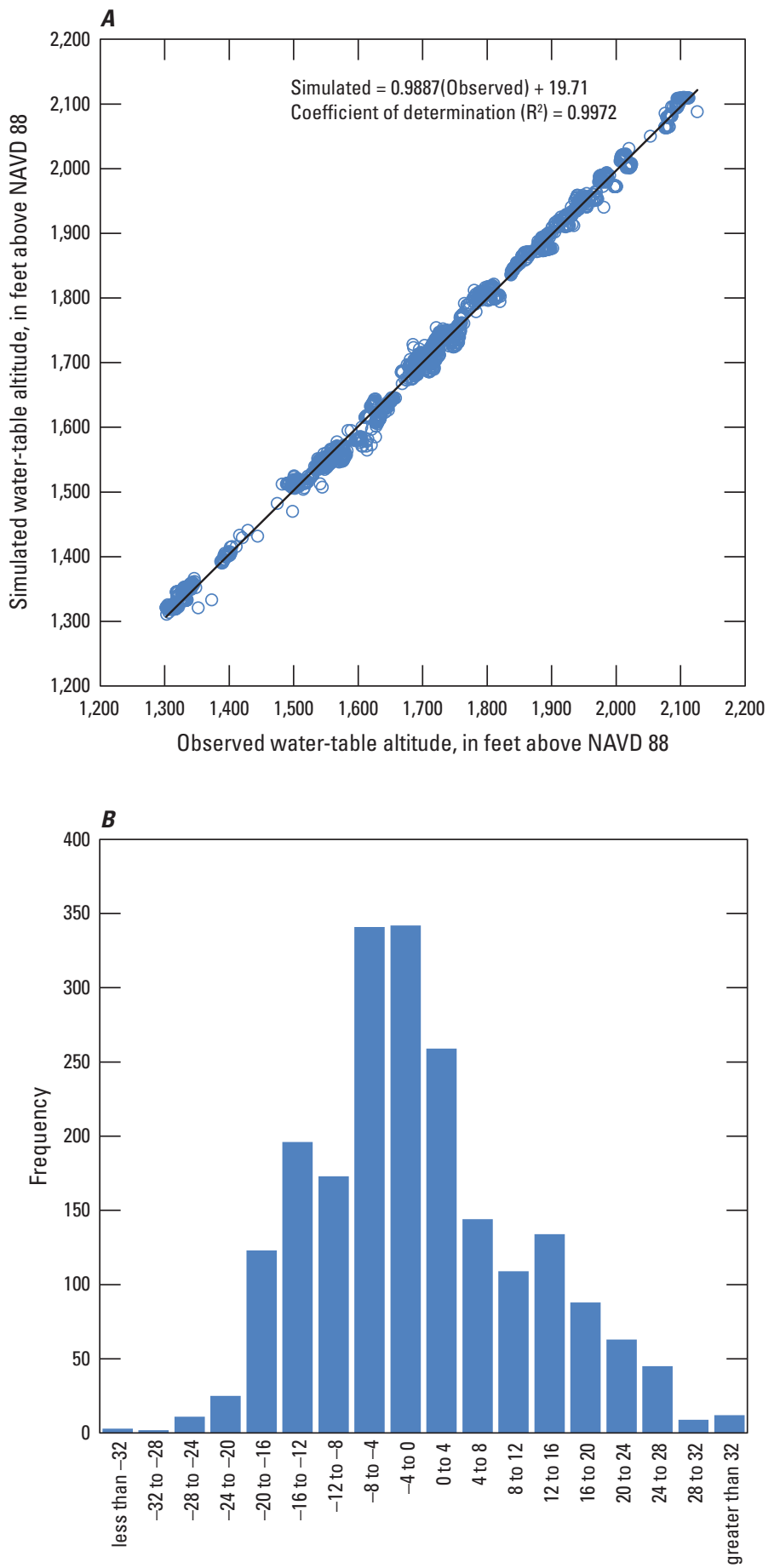

Water-table-altitude residual (observed minus simulated), in feet

Figure 26. $\quad A$, Observed and simulated water-table altitudes and $B$, water-table-altitude residual distributions for the numerical groundwater-flow model of the North Fork Red River aquifer, 1980-2013. [NAVD 88, North American Vertical Datum of 1988]
Table 11. Statistical summary of water-table-altitude residuals for the numerical groundwater-flow model of the North Fork Red River aquifer, 1980-2013.

$[ \pm$, plus or minus; RMSE, root-mean-square error]

\begin{tabular}{|c|c|c|c|}
\hline Statistic & $\begin{array}{l}\text { Steady- } \\
\text { state }\end{array}$ & Transient & Combined \\
\hline Observation count & 67 & 2,012 & 2,079 \\
\hline Mean residual, in feet & -0.9 & -0.6 & -0.6 \\
\hline $\begin{array}{l}\text { 75th-percentile residual range, } \\
\text { in feet }\end{array}$ & \pm 16 & \pm 13.9 & \pm 13.9 \\
\hline RMSE, in feet & 14.1 & 11.8 & 11.8 \\
\hline $\begin{array}{l}\text { RMSE percentage of water- } \\
\text { table relief (799 feet) }\end{array}$ & 1.8 & 1.5 & 1.5 \\
\hline
\end{tabular}

Water-table-altitude residuals were generally largest (observed greater than simulated) in the most upgradient (from local streams) terrace, where observed hydraulic gradients up to 60 feet per mile steeply slope towards the North Fork Red River and tributary streams (fig. 27). In contrast, simulated water levels near the active alluvium (base-flow discharge areas) were generally higher than observed water levels, particularly at altitudes between 1,700 and $1,800 \mathrm{ft}$ in the central part of the study area (figs. 26-27). Simulated water levels that are less than observed in the upgradient terrace and greater than observed in the downgradient active alluvium (base-flow discharge areas) could both be explained by differences between the complexity (resolution) of the simulated and observed aquifer. Because of generalizations inherent in spatial discretization, modeled flow paths are likely to be simplified and shortened versions of actual flow paths (Mandelbrot, 1983). Simulated hydraulic gradients and recharge-to-discharge travel times, therefore, are likely to be smaller than observed. Simulated well hydrographs generally matched the trends of observed well hydrographs, but the magnitude of the simulated water-level change was typically less than the magnitude of the observed water-level change (fig. 28). 


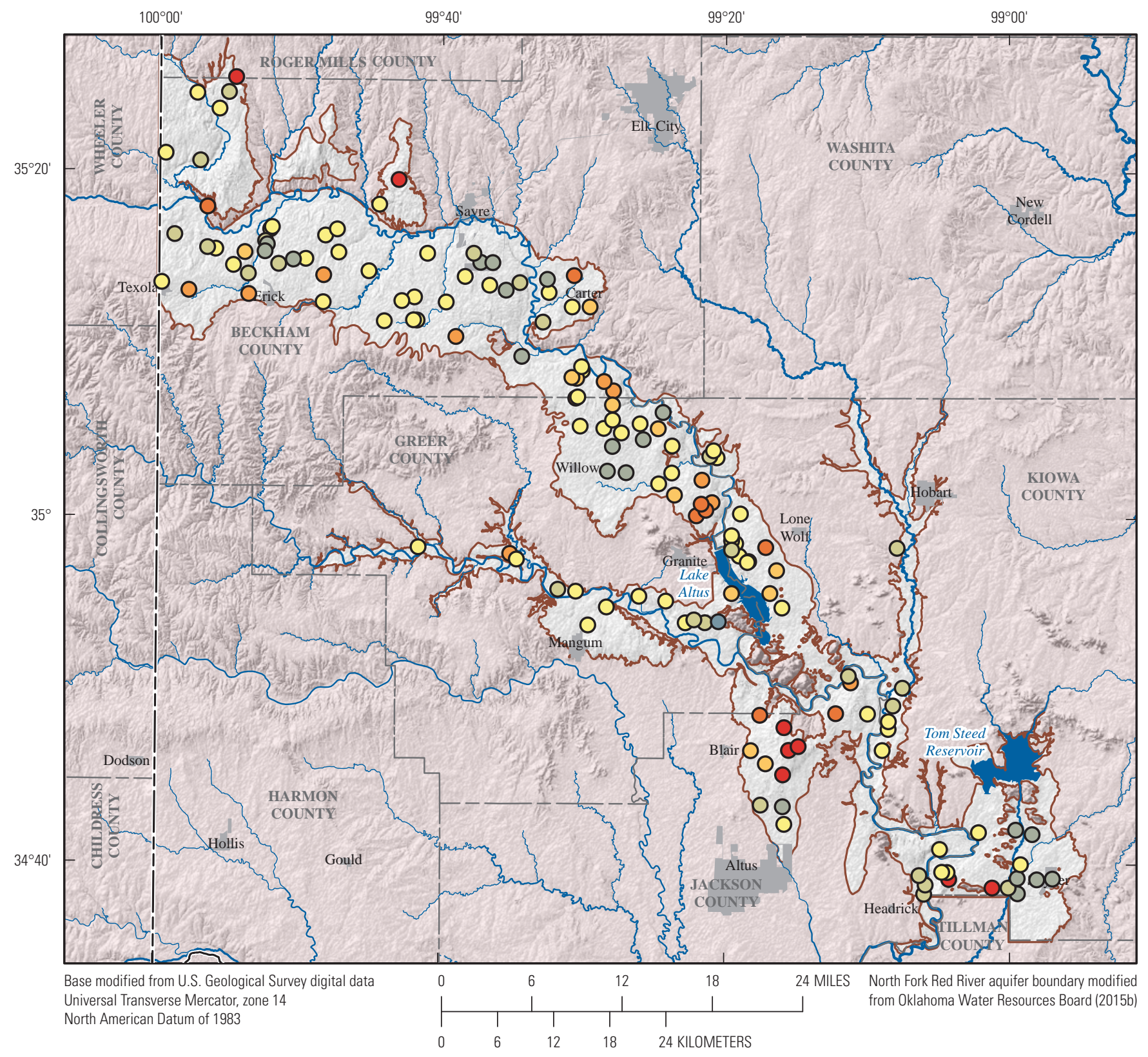

EXPLANATION

Incorporated area (U.S. Census Bureau, 2000)

North Fork Red River aquifer boundary

Mean water-table-altitude residual

(observed minus simulated), in feet, 1980-2013

O -43.2 to $-30.0 \quad$ O 6.1 to 12.0

O -29.9 to $-20.0 \quad$ O 12.1 to 20.0

O -19.9 to -12.0 ○ 20.1 to 30.0

O -11.9 to $-6.0 \quad$ O 30.1 to 49.1

O -5.9 to 6.0

Figure 27. Spatial distribution of mean water-table-altitude residuals for the numerical groundwater-flow model of the North Fork Red River aquifer, 1980-2013. 

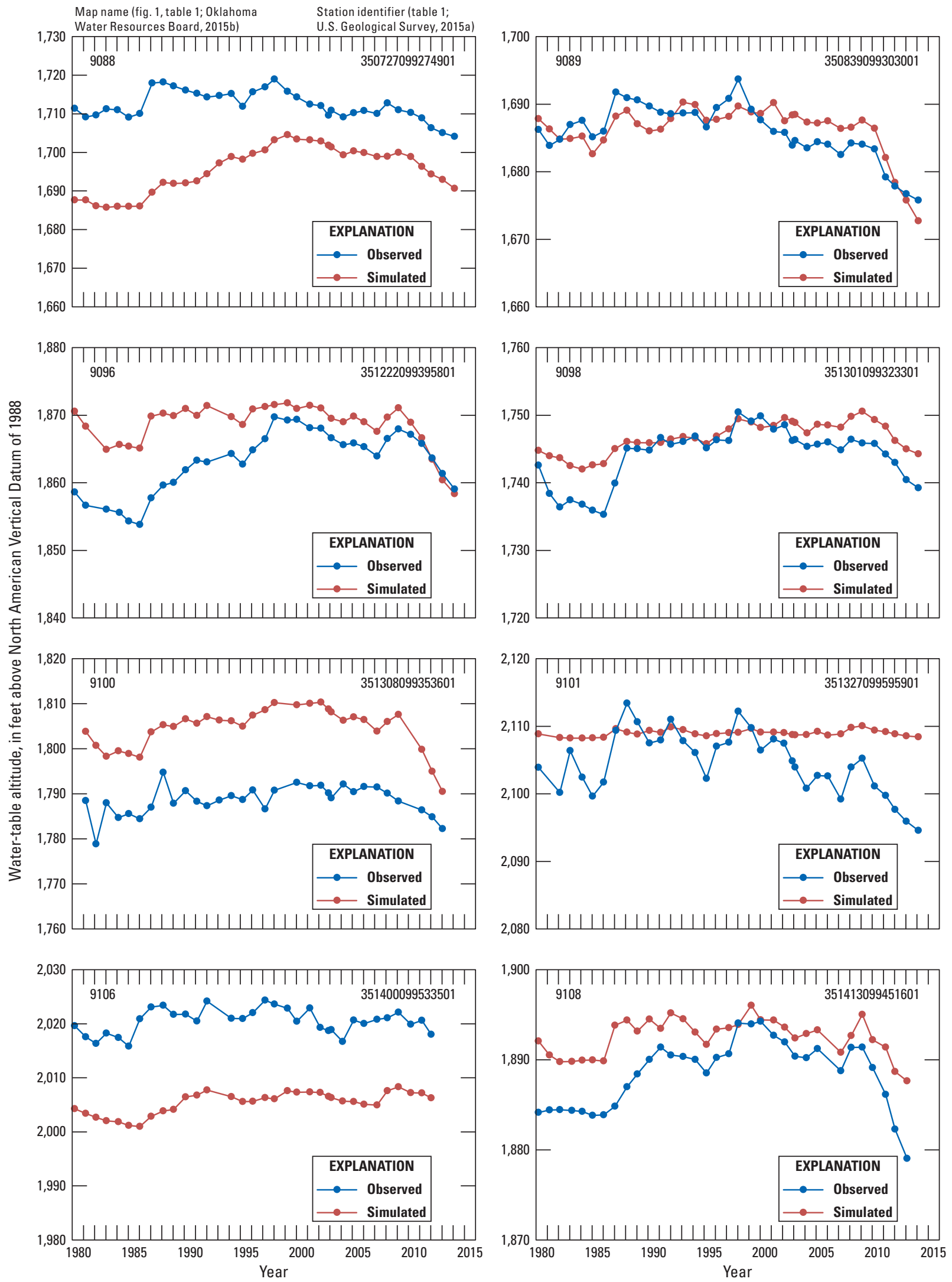

Figure 28. Observed and simulated water-table altitudes for the numerical groundwater-flow model of the North Fork Red River aquifer, 1980-2013. 

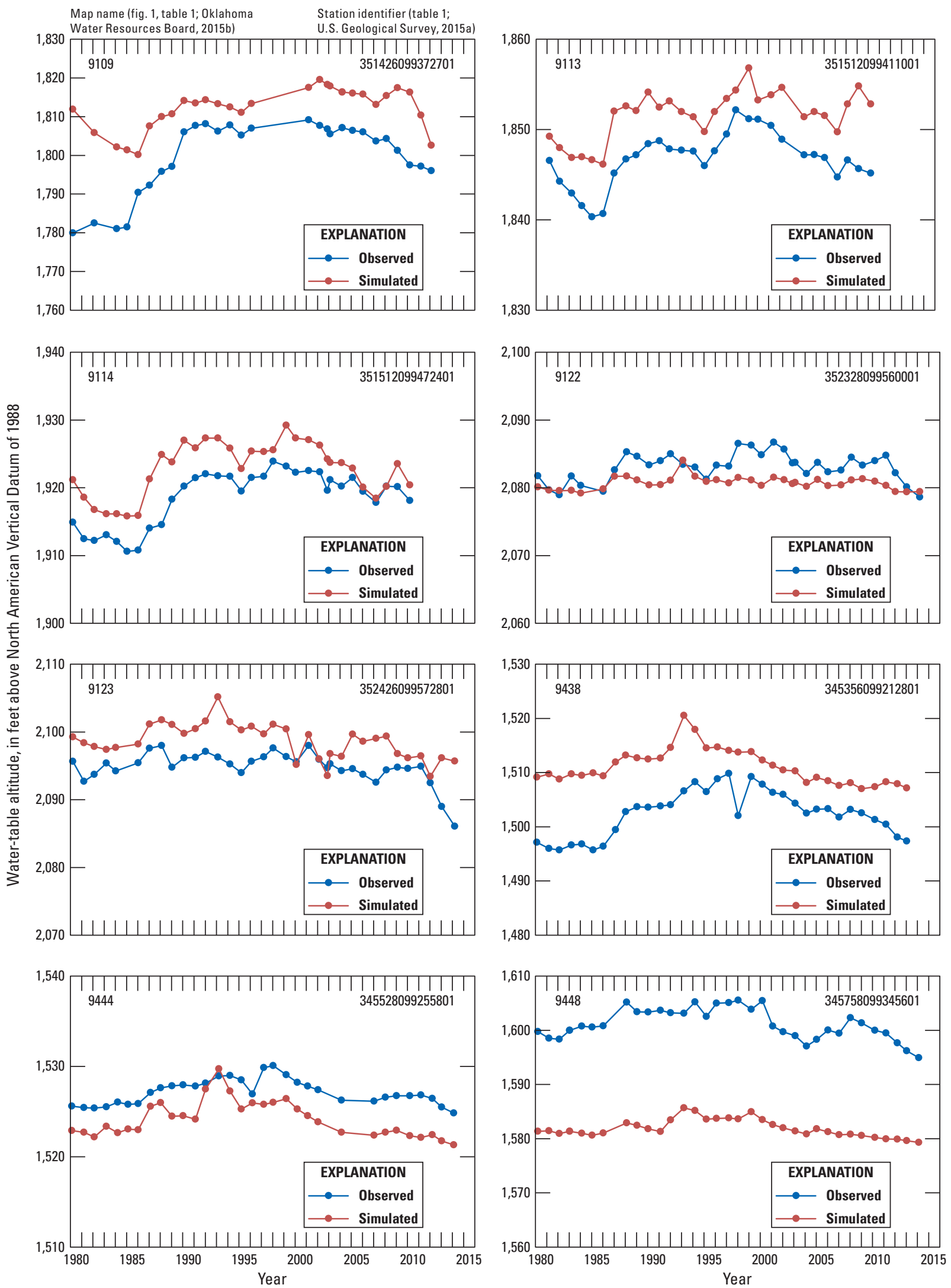

Figure 28. Observed and simulated water-table altitudes for the numerical groundwater-flow model of the North Fork Red River aquifer, 1980-2013.-Continued 

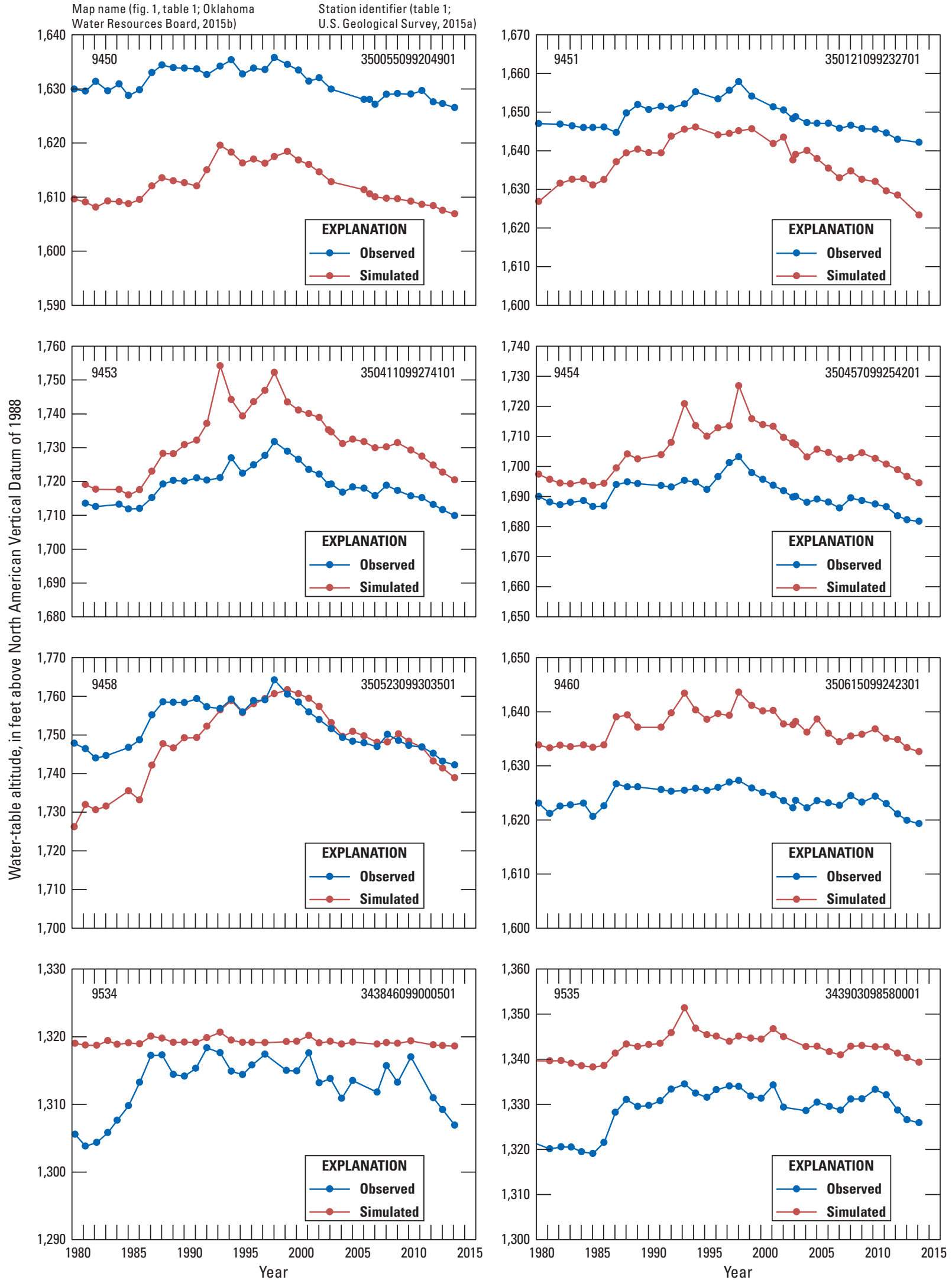

Figure 28. Observed and simulated water-table altitudes for the numerical groundwater-flow model of the North Fork Red River aquifer, 1980-2013.-Continued 

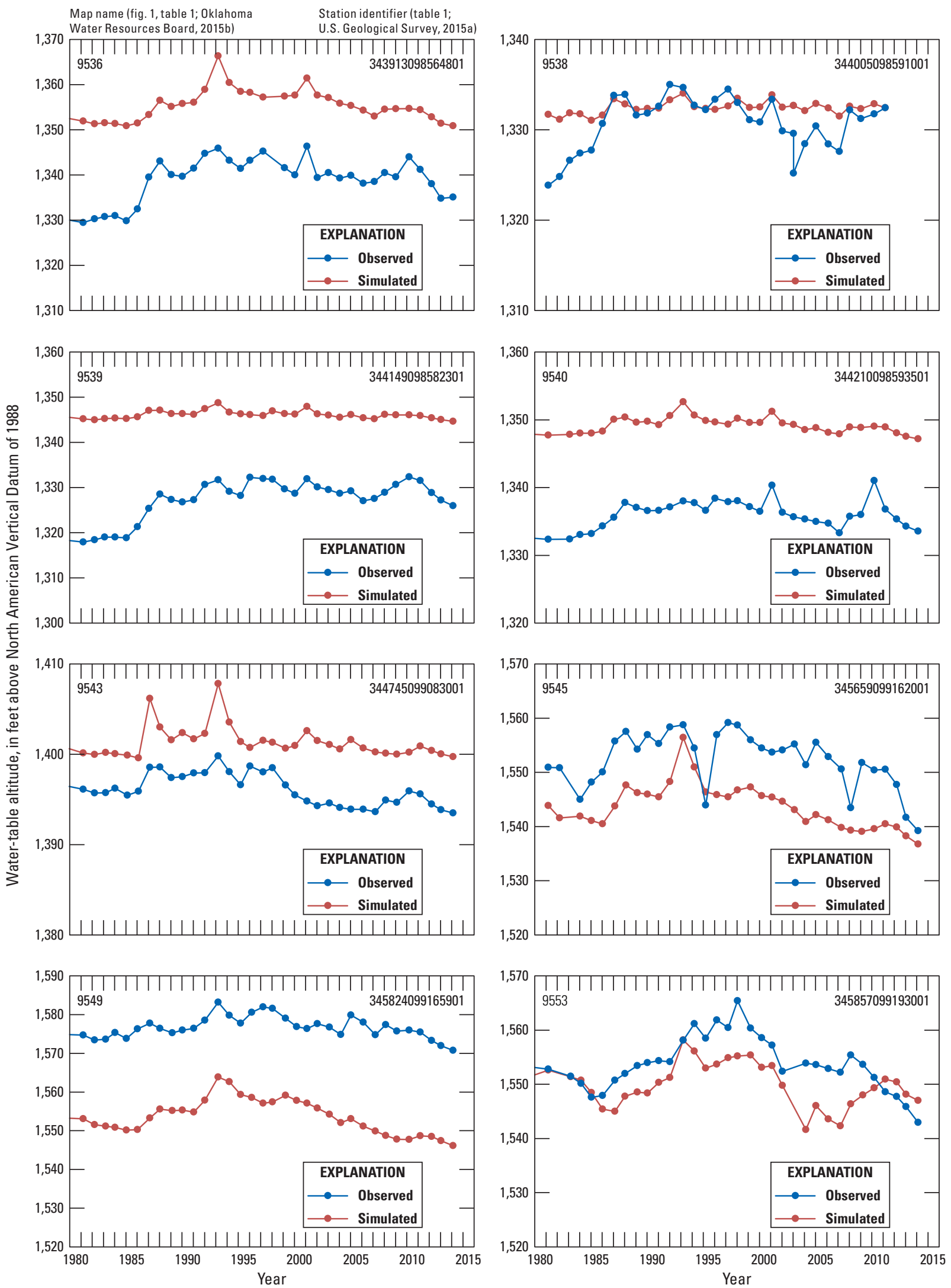

Figure 28. Observed and simulated water-table altitudes for the numerical groundwater-flow model of the North Fork Red River aquifer, 1980-2013.-Continued 
Automated calibration of the numerical model used base-flow data from the Sweetwater (07301420), Carter (07301500), and Headrick (07305000) streamgages, and manual calibration also incorporated base-flow data from the Carl (07303400), Hobart (07304500), and Snyder (07307010) streamgages (fig. 29, table 12). The mean simulated base flow was lower than the mean observed base flow for three of the six streamgages (table 12). For the two streamgages on North Fork Red River (Carter and Headrick), the RMSE was less than 10 percent of the range in observed base flow (table 12). For the four tributary streamgages, the RMSE was between about 2 and 15 percent of the range in observed base flow (table 12). The simulated base flows at the Carl (07303400) and Hobart (07304500) streamgages were mostly determined from specified inflows a short distance upstream and, therefore, are not shown in figure 29.

Periods of near zero flow occurring at most streamgages during summer months could not be completely reproduced (fig. 29, table 12). These overestimated summer low flows could be the result of underestimated saturated-zone ET, which is greatest in the summer months; however, saturated-zone ET could not be increased without also increasing recharge or negatively affecting residuals of other calibration targets. Base-flow residuals were generally larger during spring and fall high-flow periods than during summer low-flow periods (fig. 29), possibly indicating that observed base flows were overestimated by the BFI code (either because of reservoir releases or recharge processes such as bank storage flow or interflow that mostly operate on a submonthly time scale). The primary source of water to the aquifer is recharge, so large positive base-flow residuals (observed greater than simulated) also could be caused by underestimated or incorrectly distributed (spatially) recharge. Base-flow residuals were largest for the Headrick streamgage (07305000) (table 12). The observed base flow for the Headrick streamgage (07305000) is, to some degree, related to releases from Lake Altus that occurred during the study period, particularly during years 1986-88, 1993, 1997-98, and 2007 (fig. 29). No reliable or justifiable method was found for removing the effects of the Lake Altus and Tom Steed Reservoir releases on the observed base flows at the respective Headrick (07305000) and Snyder (07307010) streamgages.

The mean Lake Altus stage residual was $0.4 \mathrm{ft}$ (table 13), indicating that the mean simulated stage was slightly lower than the mean observed stage (fig. 30). The RMSE was $3.7 \mathrm{ft}$, and 75 percent of the lake-stage residuals were within $\pm 4.2 \mathrm{ft}$ of observed stage. The maximum observed and simulated stage were both $1,561 \mathrm{ft}$, whereas the minimum simulated stage was $3 \mathrm{ft}$ higher than the minimum observed stage. The largest Lake Altus stage residuals occurred in late 1981, late 1985, late 1994, and late 1998 when lake storage was relatively low; simulated Lake Altus stage also poorly matched observed stage during drought conditions in 2011-13 (fig. 30). 

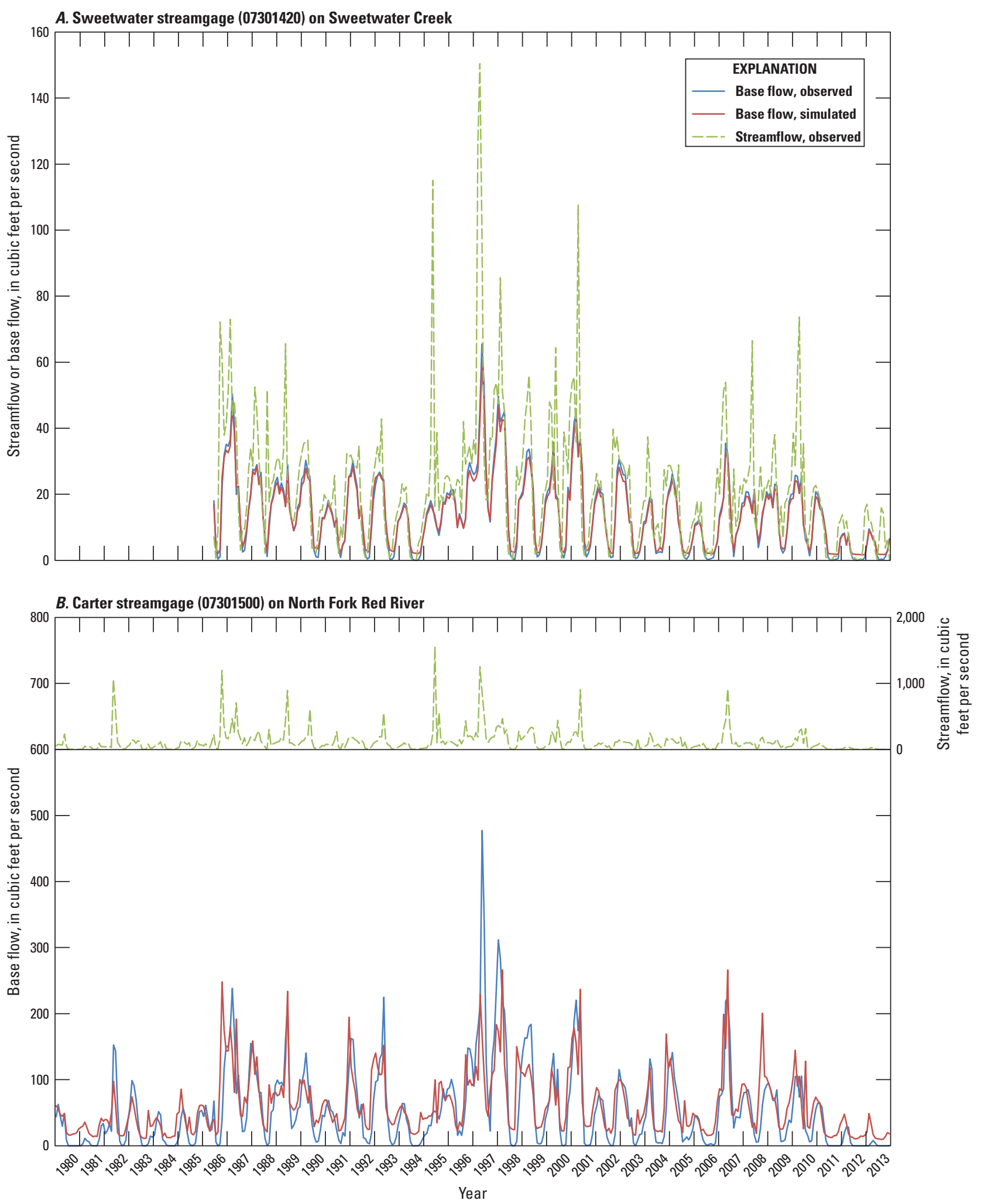

Figure 29. Observed streamflow, observed base flow, and simulated base flow at $A$, Sweetwater streamgage (07301420) on Sweetwater Creek; $B$, Carter streamgage (07301500) on North Fork Red River; C, Headrick streamgage (07305000) on North Fork Red River; and $D$, Snyder streamgage (07307010) on Otter Creek for the numerical groundwater-flow model of the North Fork Red River aquifer, southwest Oklahoma, 1980-2013. 

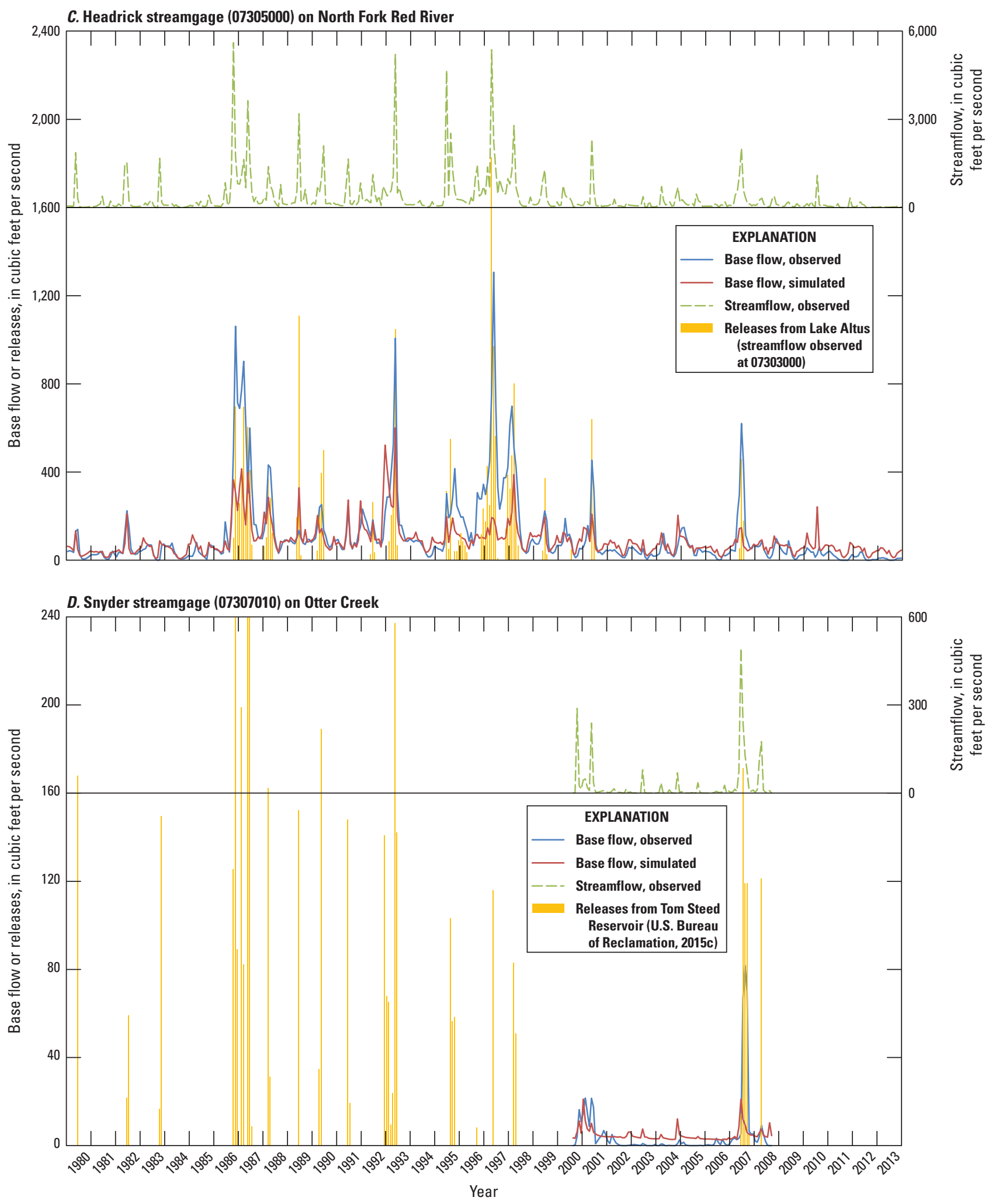

Figure 29. Observed streamflow, observed base flow, and simulated base flow at $A$, Sweetwater streamgage (07301420) on Sweetwater Creek; B, Carter streamgage (07301500) on North Fork Red River; $C$, Headrick streamgage (07305000) on North Fork Red River; and $D$, Snyder streamgage (07307010) on Otter Creek for the numerical groundwater-flow model of the North Fork Red River aquifer, southwest Oklahoma, 1980-2013.-Continued 
Table 12. Statistical summary of base-flow residuals for the numerical groundwater-flow model of the North Fork Red River aquifer, $1980-2013$.

[Residual is calculated as the observed minus the simulated value; thus, a negative number indicates higher simulated than observed values. $\mathrm{ft}^{3} / \mathrm{s}$, cubic foot per second; RMSE, root-mean-square error; \pm , plus or minus]

\begin{tabular}{|c|c|c|c|c|c|c|c|c|c|c|c|c|c|}
\hline \multirow[b]{2}{*}{ Station } & \multicolumn{2}{|c|}{$\begin{array}{l}\text { Available data in the } \\
\text { study period 1980-2013 }\end{array}$} & \multirow{2}{*}{$\begin{array}{l}\text { Drainage } \\
\text { area } \\
\text { (square } \\
\text { miles) }\end{array}$} & \multicolumn{3}{|c|}{$\begin{array}{l}\text { Observed base flow } \\
\qquad\left(\mathrm{ft}^{3} / \mathrm{s}\right)\end{array}$} & \multicolumn{3}{|c|}{$\begin{array}{c}\text { Simulated base flow } \\
\left(\mathrm{ft}^{3} / \mathrm{s}\right)\end{array}$} & \multicolumn{3}{|c|}{$\begin{array}{l}\text { Base-flow residuals } \\
\qquad\left(\mathrm{ft}^{3} / \mathbf{s}\right)\end{array}$} & \multirow{2}{*}{$\begin{array}{c}\text { RMSE } \\
\text { percentag } \\
\text { of range in } \\
\text { observed } \\
\text { base flow }\end{array}$} \\
\hline & Begin & End & & $\begin{array}{l}\text { Mini- } \\
\text { mum }\end{array}$ & Mean' & Maximum & $\begin{array}{l}\text { Mini- } \\
\text { mum }\end{array}$ & Mean & Maximum & Mean & $\begin{array}{l}\text { 75th- } \\
\text { percen- } \\
\text { tile range }\end{array}$ & RMSE & \\
\hline $\begin{array}{l}\text { Sweetwater streamgage } \\
(07301420) \text { on Sweetwater } \\
\text { Creek }\end{array}$ & 4/22/1986 & $12 / 31 / 2013$ & 437 & 0.0 & 14.6 & 65.5 & 1.7 & 14.3 & 59.5 & 0.2 & \pm 1.6 & 1.4 & 2.2 \\
\hline $\begin{array}{l}\text { Carter streamgage (07301500) } \\
\text { on North Fork Red River }\end{array}$ & 1/1/1980 & $12 / 31 / 2013$ & 2,652 & 0.0 & 54.6 & 477.2 & 9.4 & 61.5 & 266.2 & -6.8 & \pm 30.3 & 40.8 & 8.6 \\
\hline $\begin{array}{l}\text { Carl streamgage (07303400) on } \\
\text { Elm Fork Red River }\end{array}$ & 10/1/1994 & $12 / 31 / 2013$ & 438 & 0.2 & 15.5 & 124.2 & 1.4 & 21.2 & 129.6 & -5.6 & \pm 6.1 & 9.5 & 7.7 \\
\hline $\begin{array}{l}\text { Hobart streamgage (07304500) } \\
\text { on Elk Creek }\end{array}$ & 1/1/1980 & 9/30/1993 & 549 & 0.1 & 36.0 & 356.6 & 0.0 & 35.9 & 385.6 & 0.0 & \pm 4.1 & 6.4 & 1.8 \\
\hline $\begin{array}{l}\text { Headrick streamgage } \\
\text { (07305000) on North Fork } \\
\text { Red River }\end{array}$ & 1/1/1980 & $12 / 31 / 2013$ & 4,560 & 0.0 & 111.6 & 1,306.6 & 6.7 & 88.3 & 600.3 & 23.3 & \pm 46.0 & 127.2 & 9.7 \\
\hline $\begin{array}{l}\text { Snyder streamgage (07307010) } \\
\text { on Otter Creek }\end{array}$ & $7 / 1 / 2000$ & $10 / 5 / 2008$ & 162 & 0.0 & 4.8 & 81.9 & 2.6 & 4.9 & 21.1 & -0.1 & \pm 3.8 & 12.0 & 14.7 \\
\hline
\end{tabular}

${ }^{1}$ Mean observed base flow may differ from values in table 2 because of rounding and inclusion of partial years of record. 
Table 13. Statistical summary of lake-stage residuals for the numerical groundwater-flow model of the North Fork Red River aquifer, 1980-2013.

[RMSE, root-mean-square error; \pm , plus or minus]

\begin{tabular}{lccc}
\hline \multirow{2}{*}{\multicolumn{1}{c}{ Observation }} & \multicolumn{3}{c}{ Lake stage } \\
\cline { 2 - 4 } & Minimum & Mean & Maximum \\
\hline Observed, in feet & 1,523 & 1,546 & 1,561 \\
Simulated, in feet & 1,526 & 1,546 & 1,561 \\
Mean residual, in feet & & 0.4 & \\
RMSE, in feet & 3.7 \\
75th-percentile residual & & \pm 4.2 \\
$\quad$ range, in feet & & & \\
\hline
\end{tabular}
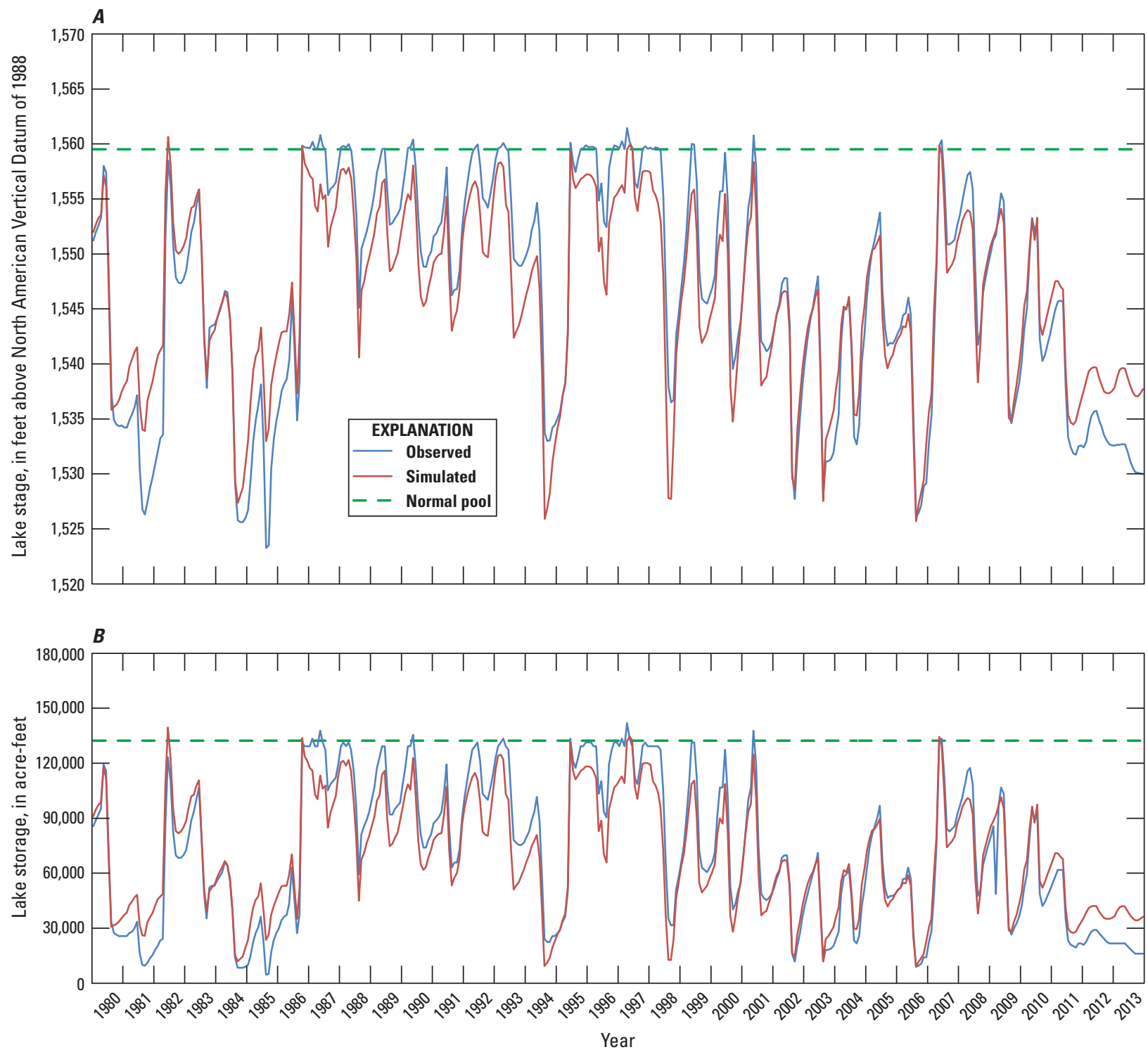

Figure 30. Lake Altus $A$, stage and $B$, simulated storage for the numerical groundwater-flow model of the North Fork Red River aquifer, 1980-2013. 


\section{Calibrated Water Budget}

The calibrated water budget (table 14) lists mean annual inflows and outflows for the calibrated numerical model for the period 1980-2013; a sub-accounting for areas upgradient and downgradient from Lake Altus was computed by using the ZONEBUDGET utility (Harbaugh, 1990). The calibrated water budget shows more inflow and outflow categories than the conceptual model (table 8), because subcomponents of the net water-budget categories can be quantified in the calibrated water budget. Simulated recharge (79 percent of inflows) was the largest inflow for the calibrated numerical model; seepage from streams was about 14 percent, lakebed seepage was about 4 percent, and lateral groundwater inflow was about 3 percent of inflows. Seepage to streams ( 56 percent of outflows) was the largest outflow for the calibrated numerical model; saturated-zone ET was about 23 percent, lateral groundwater outflow (with springs and seeps) was about 10 percent, well withdrawals were about 8 percent, and lakebed seepage was about 2 percent of outflows.

Recharge for the calibrated numerical model (about $122,000 \mathrm{acre}-\mathrm{ft} / \mathrm{yr}$ or $2.94 \mathrm{in} / \mathrm{yr}$ over the aquifer area of 497,582 acres, table 14) was about 6 percent greater than that of the conceptual model (fig. 16, table 8). Net streambed seepage for the calibrated numerical model was about 4 percent less than that of the conceptual model. This difference could be caused in part by streambed seepage between Carter (07301500) and Lake Altus that was not estimated in the conceptual model. Saturated-zone ET for the calibrated numerical model, which was estimated by using many assumptions, was about 40 percent greater than that of the conceptual model (but less than the saturated-zone ET for the similar Reach I calibrated numerical models of Ryter and Correll [2016] and Ellis and others [2017]). The 67-percent (about 4,800-acre-ft/yr) increase in simulated lateral flow, seeps, and springs as compared to the conceptual model reflects uncertainty in estimating these components without published flow rates. The simulated well withdrawals were about 16 percent less than the conceptual-model well withdrawals because of (1) previously described thresholds (see Well Withdrawals section of this report) applied to permits and wells and (2) a lack of adequate simulated saturation in some areas of the terrace; well withdrawal rates specified in the model are automatically reduced when the simulated saturated thickness nears zero.

Table 14. Mean annual water budget for the numerical groundwater-flow model of the North Fork Red River aquifer, 1980-2013.

[All units in acre-feet per year; net budget totals are calculated as inflow minus outflow; therefore, positive values indicate net inflow, and negative numbers indicate net outflow; components may not sum to totals because of rounding]

\begin{tabular}{|c|c|c|c|c|}
\hline Water-budget category & $\begin{array}{c}\text { Upgradient } \\
\text { from Lake Altus }\end{array}$ & $\begin{array}{l}\text { Downgradient } \\
\text { from Lake Altus }\end{array}$ & Total & $\begin{array}{l}\text { Percentage of } \\
\text { water budget }\end{array}$ \\
\hline \multicolumn{5}{|c|}{ Inflow } \\
\hline Streambed seepage from streams & 9,597 & 12,082 & 21,679 & $14 \%$ \\
\hline Lakebed seepage inflow & 5,009 & 1,320 & 6,328 & $4 \%$ \\
\hline \multicolumn{5}{|c|}{ Outflow } \\
\hline Streambed seepage to streams & 43,879 & 46,530 & 90,409 & $56 \%$ \\
\hline Saturated-zone evapotranspiration & 21,868 & 15,591 & 37,459 & $23 \%$ \\
\hline Lateral groundwater outflow, springs, and seeps & 7,529 & 9,223 & 16,752 & $10 \%$ \\
\hline \multicolumn{5}{|c|}{ Net water-budget totals } \\
\hline Net streambed seepage & $-34,282$ & $-34,448$ & $-68,730$ & \\
\hline Net lateral flow, springs, and seeps & $-2,828$ & $-9,223$ & $-12,051$ & \\
\hline Net lakebed seepage & 2,379 & 652 & 3,031 & \\
\hline Net change in groundwater storage ${ }^{2}$ & 4,165 & 2,117 & 6,282 & \\
\hline
\end{tabular}

${ }^{1}$ Equals 2.94 inches per year over the aquifer area of 497,582 acres.

${ }^{2}$ Positive net change in groundwater storage indicates loss of groundwater storage from the aquifer; loss of groundwater storage is reported as an aquifer inflow in the numerical groundwater-flow model mass balance. 
Simulated groundwater storage generally increased during a relatively long period of above-average precipitation (fig. 3) and recharge (fig. 31) in 1985-2000. This period was followed by a period of generally near-average to belowaverage precipitation (fig. 3 ) and recharge (fig. 31) during 2001-13 when simulated groundwater storage decreased, particularly during 2010-13. The period 2010-13 coincides with a regional drought in southwest Oklahoma (fig. 3). A correlated water-level response to these precipitation trends is demonstrated in the hydrographs of water-table-altitude observation wells located in the terrace, particularly wells
9089, 9096, 9100, 9101, 9108, and 9109 (fig. 28). Because recharge accounts for nearly 80 percent of the total calibrated model inflow to the aquifer (fig. 16; table 14), changes in precipitation have a large effect on groundwater storage and the annual water budget. The annual water budget during years when recharge was large relative to the period of record mean, such as 1986-87 and 1995 (fig. 31), was greater than the annual water budget during other years of the study period. At the end of the study period, mean simulated outflows exceeded inflows by about 6,300 acre-ft/yr (table 14). This difference is equivalent to a cumulative net change in groundwater storage
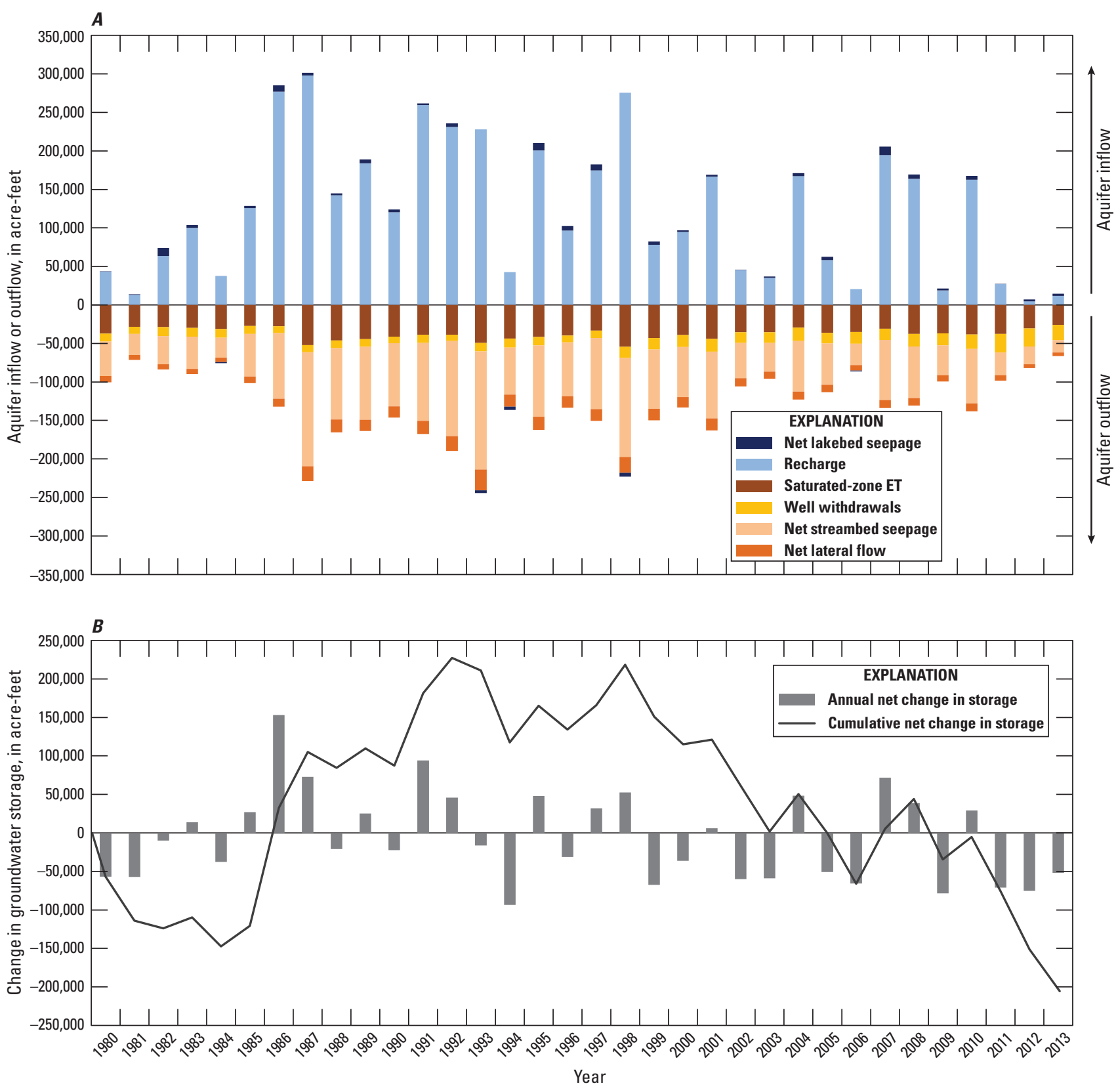

Figure 31. $A$, Annual inflows and outflows and $B$, annual change in groundwater storage for the numerical groundwater-flow model of the North Fork Red River aquifer, 1980-2013. 
of about 214,000 acre-ft (fig. 31) for 1980-2013 (34 years), or a cumulative net water-level decline of about $3.6 \mathrm{ft}$. This net change in groundwater storage was about the same as the one calculated from annual water-level measurements for the conceptual model (6,150 acre-ft/yr, table 8).

Mean monthly simulated aquifer inflows, primarily from recharge and seepage from streams, tended to be greatest during May and June (fig. 32A), which corresponds to the months of greatest precipitation (fig. 4). Mean monthly simulated aquifer outflows, primarily from seepage to streams, saturated-zone ET, and well withdrawals, were greatest in July and August (fig. 32A). During those summer months, seepage to streams was reduced by water-level declines from large saturated-zone ET outflows and well withdrawals (mostly for irrigation use). In July, mean saturated-zone ET equaled or exceeded all other outflows and nearly equaled the sum of all inflows (fig. 32A). Though mean inflows exceeded mean outflows in 9 of 12 months, the magnitude of mean outflows in July and August (fig. 32B) caused mean annual outflows to exceed mean annual inflows for the study period (table 14).

Simulated storage in Lake Altus decreased by about 25,000 acre-ft during the study period 1980-2013 (fig. 33B). Lake Altus and the surrounding North Fork Red River aquifer are hydrologically connected, so some declines in Lake Altus stage and storage were expected to occur during periods of declining water-table altitudes in the aquifer. Simulated annual lakebed seepage to the aquifer and direct lake-surface precipitation, however, were a minimal part of the Lake Altus water budget (fig. 33A). Periods of decreased Lake Altus stage and storage typically occurred during years of decreased base flow (figs. 30, 33, and 19B). Because nearly half of the streamflow in the North Fork Red River upstream from Lake Altus (at the Carter streamgage [07301500]) occurs as base flow (fig. 19B, table 2), water-table-altitude declines in the aquifer upgradient from Lake Altus had a greater effect on simulated Lake Altus stage and storage than did water-tablealtitude declines near Lake Altus.

\section{Calibrated Parameter Values and Sensitivities}

A sensitivity analysis was performed by using sensitivities generated by PEST (Doherty, 2010) to ensure that the parameters used during the calibration process were effective in reducing the objective function and the numerical model error. During calibration, PEST records the sensitivity of each calibration target to regular percentage changes in parameters. These sensitivities are a measure of the change in residuals affected by adjustments to a parameter; parameters with greater sensitivities more greatly affect residuals. Sensitivities were calculated by using the Jacobian matrix output from PEST and were summed for each parameter group (fig. 34).

The observation groups were most sensitive to changes in the recharge and hydraulic conductivity parameters (fig. 34). Recharge was the largest aquifer inflow (table 14), which, when combined with the high hydraulic conductivity alluvium and terrace deposits, affected the water-table altitude, base flows, streambed seepage, and lake stage. Several watertable-altitude observations were located near drain cells along the southernmost model boundary, and these observations had a relatively large sensitivity to the drain conductance. Also, several drain cells were located near Lake Altus (drn4, fig. 21), resulting in a relatively large sensitivity to the drain conductance. Saturated-zone ET changes resulted in a large sensitivity for the lake-stage observations because surfacewater inflows contributed the majority of inflow to Lake Altus. The observation groups also were sensitive to changes in Sy. The GHB cells in the model were located only at the Texas border (fig. 21); therefore, most observation groups had little sensitivity to changes in the GHB conductance values. The lake-stage observation group typically had the greatest sensitivity of the four observation groups; this observation group was most sensitive to recharge and least sensitive to GHB conductance (fig. 34).

Recharge multipliers applied to the monthly SWB grids increased the mean annual recharge from about 87,000 acre-ft/yr (fig. 22) to about 122,000 acre-ft/yr (table 14). Recharge for 72 percent of the stress periods was less than 20 percent of the mean recharge for the study period. Recharge multipliers applied in the remaining 28 percent of the stress periods, therefore, caused the majority of the increase in mean annual recharge for the calibrated model. Monthly mean calibrated recharge was greater than monthly mean precalibrated recharge for all months except April (fig. 35). With the exception of April, monthly mean calibrated recharge was 27-85 percent greater than the respective monthly mean precalibrated recharge (fig. 35).

Upgradient from Lake Altus, calibrated Kh ranged from about 8 to $114 \mathrm{ft} / \mathrm{d}$ and averaged $36.5 \mathrm{ft} / \mathrm{d}$ (fig. 36, table 10). Downgradient from Lake Altus, calibrated Kh ranged from about 16 to $119 \mathrm{ft} / \mathrm{d}$ and averaged $57.8 \mathrm{ft} / \mathrm{d}$ (fig. 36, table 10). About 0.5 percent of the calibrated Kh values in the numerical model were outside of the Kh range (1-97 ft/d) defined in the hydrogeologic framework. The increase in mean calibrated Kh from upgradient to downgradient from Lake Altus is consistent with even greater mean $\mathrm{Kh}(117 \mathrm{ft} / \mathrm{d})$ reported for the most downgradient aquifer, the Tillman Terrace aquifer (Osborn, 2002; fig. 1). The calibrated Sy (0.12) was unchanged from the hydrogeologic framework. 

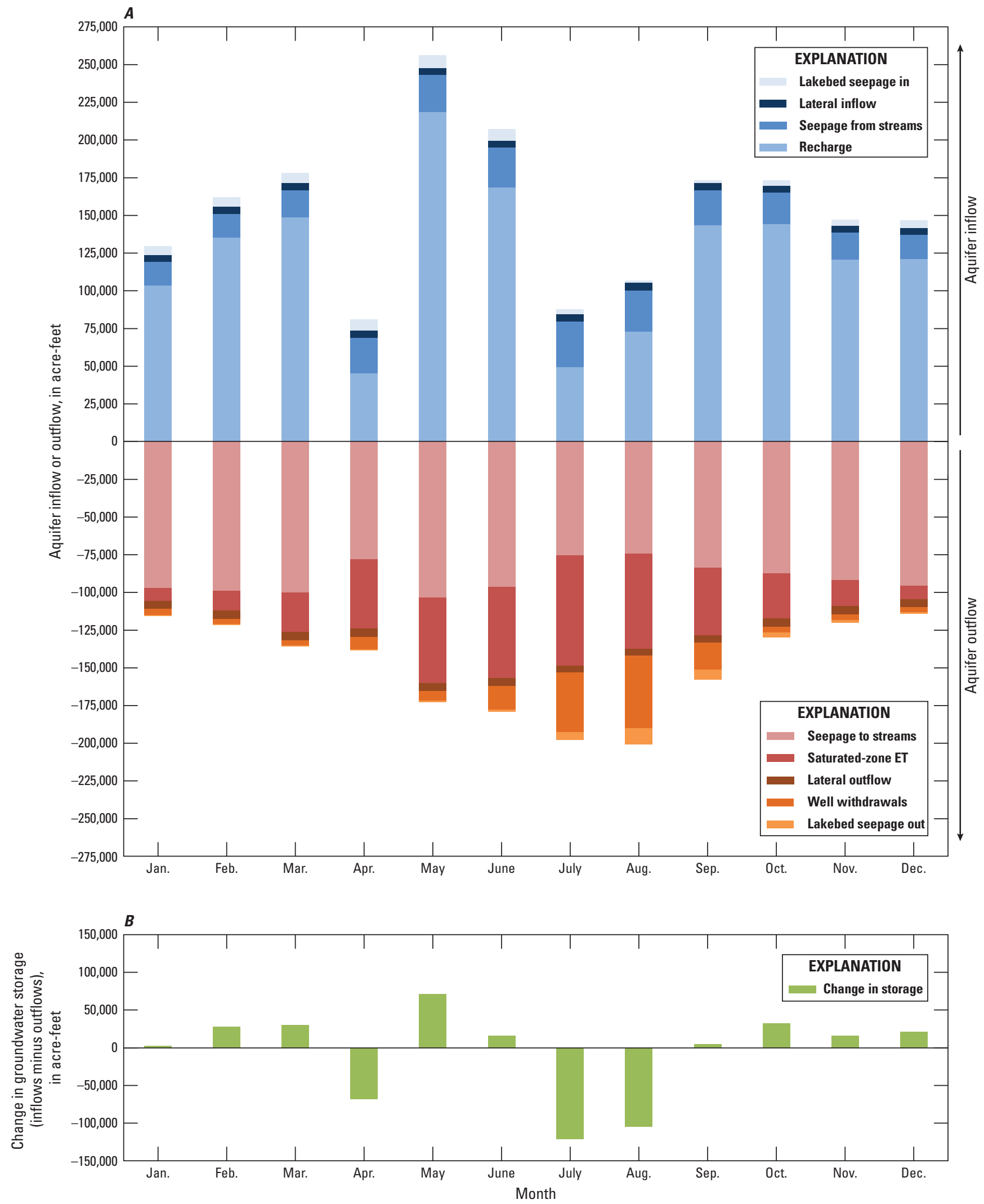

Figure 32. A, Mean monthly aquifer inflows and outflows and $B$, mean monthly change in groundwater storage for the North Fork Red River aquifer, 1980-2013. 

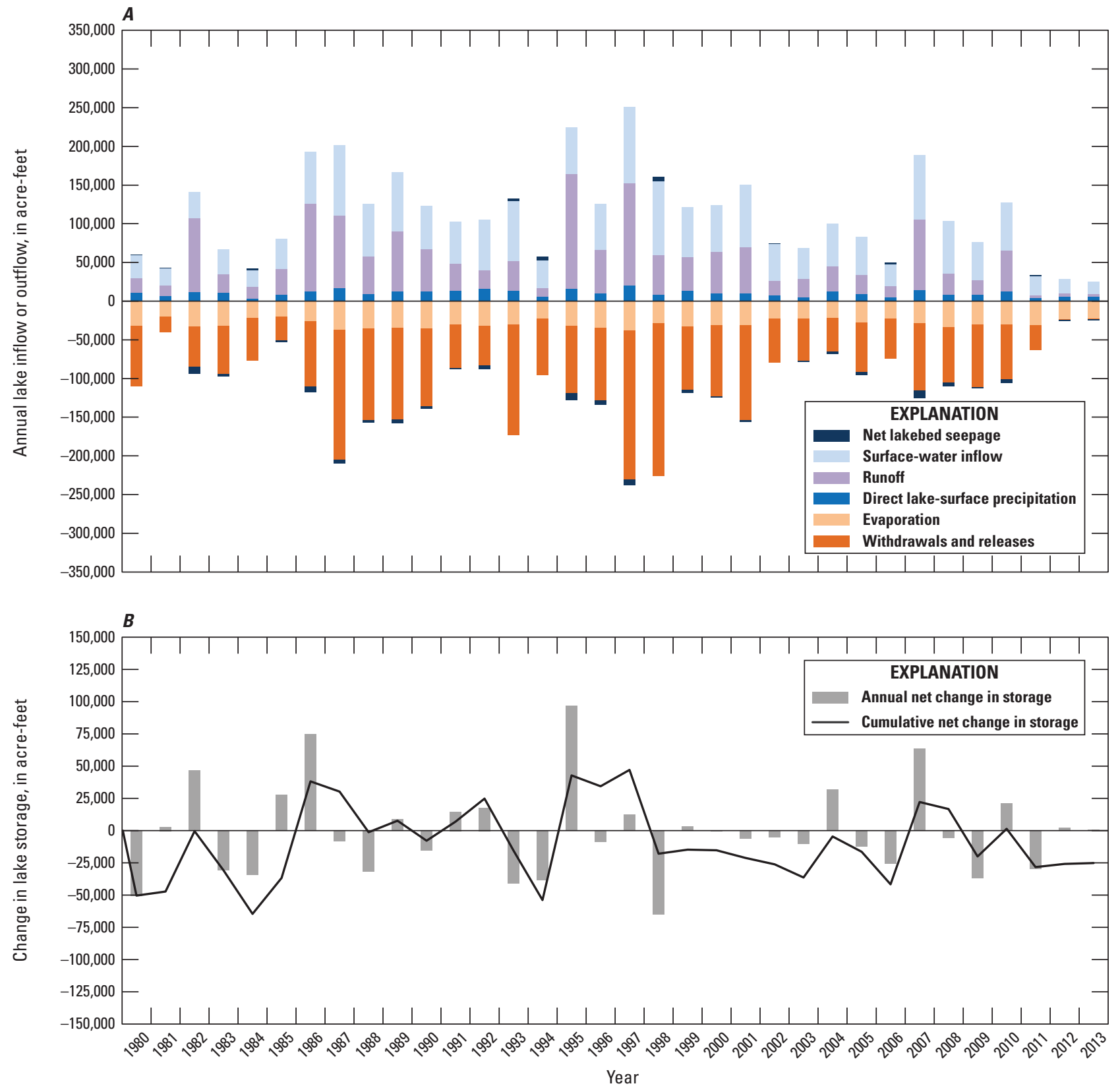

Figure 33. A, Annual lake inflows and outflows and $B$, change in lake storage for Lake Altus in the numerical groundwater-flow model of the North Fork Red River aquifer, 1980-2013. 


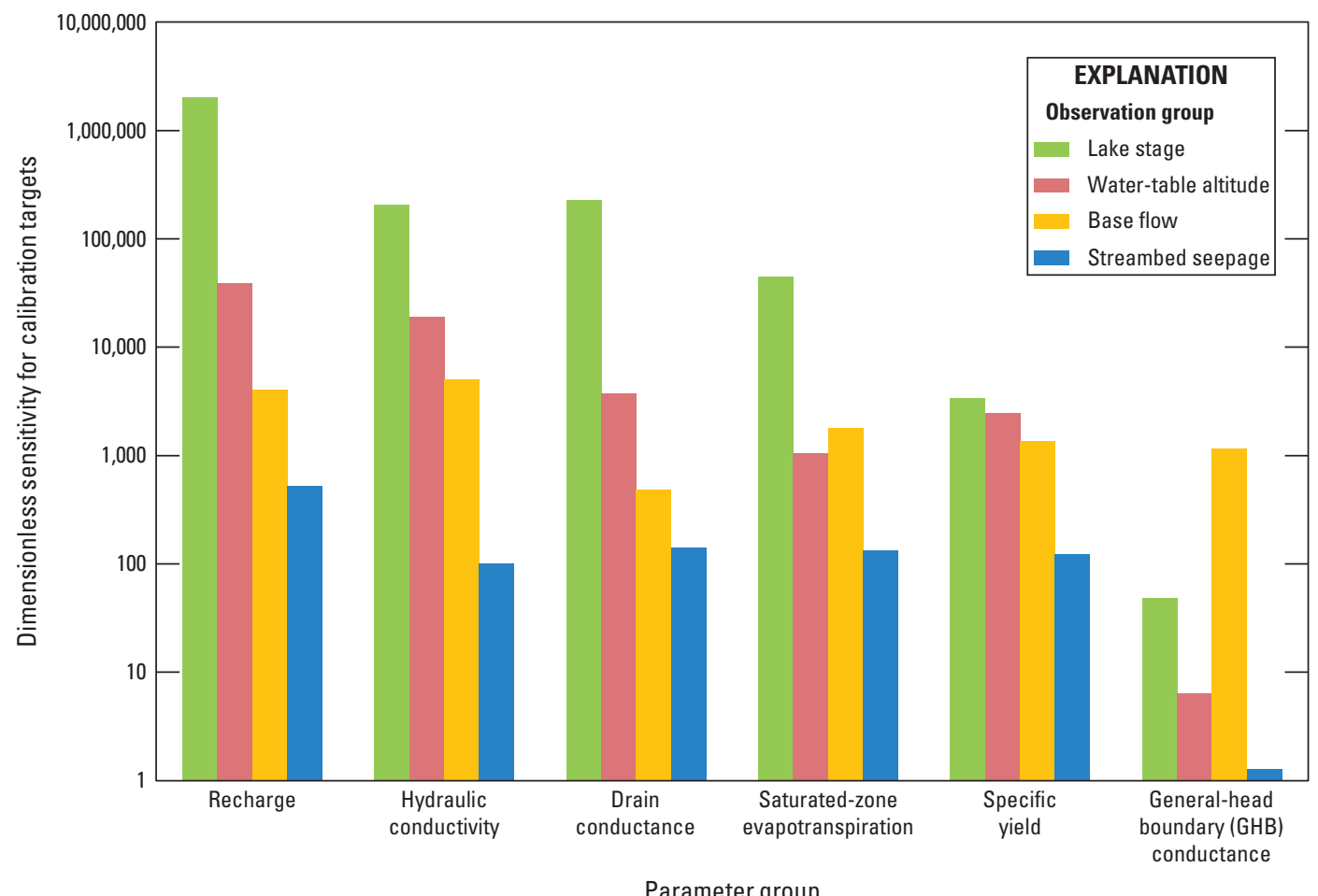

Figure 34. Observation group sensitivity by parameter group in the numerical groundwater-flow model for the North Fork Red River aquifer, 1980-2013.

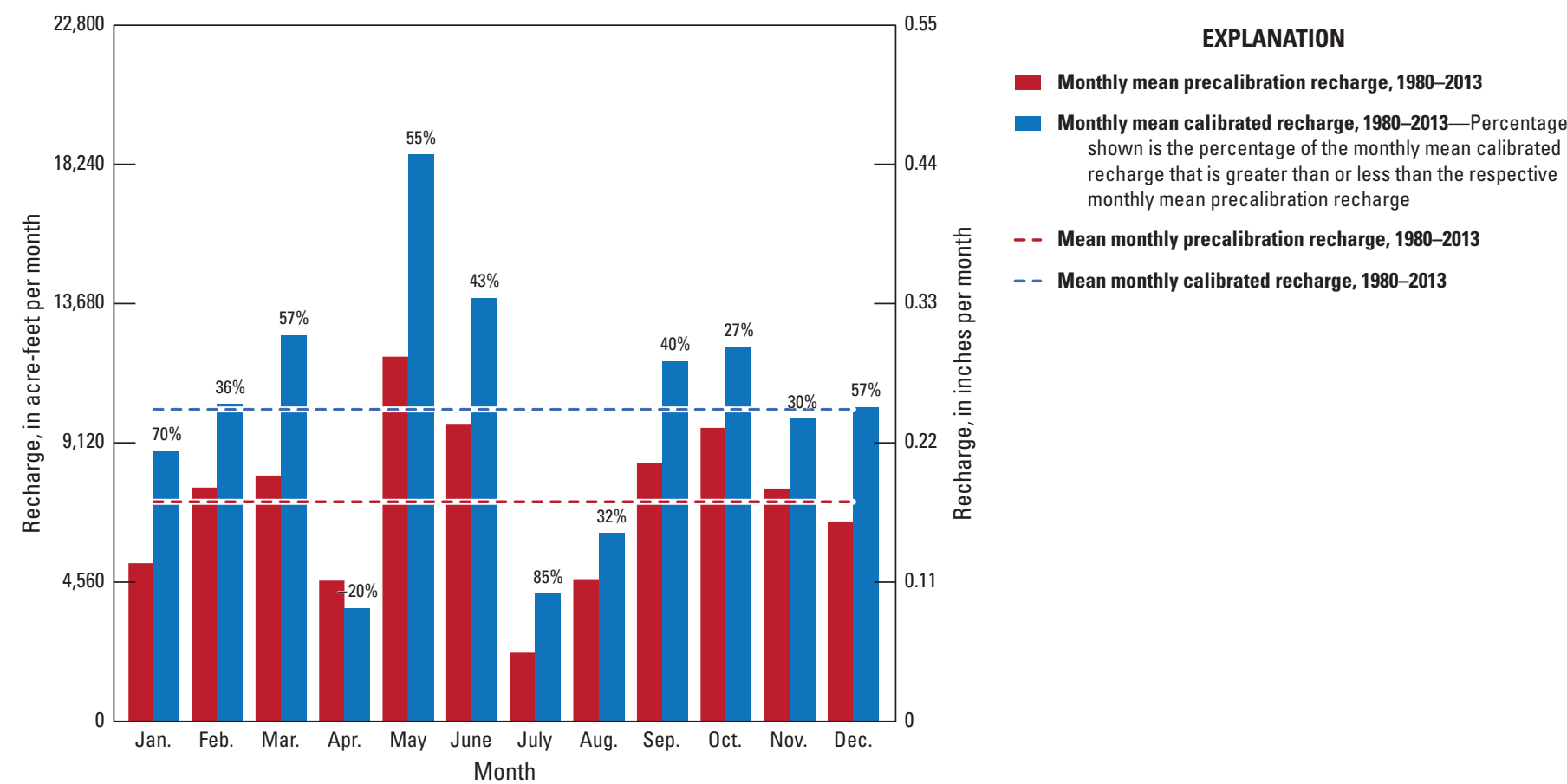

Figure 35. Monthly mean precalibration recharge and monthly mean calibrated recharge for the numerical groundwater-flow model of the North Fork Red River aquifer, 1980-2013. Note that aquifer area of 497,582 acres was used to convert acre-feet to inches. 


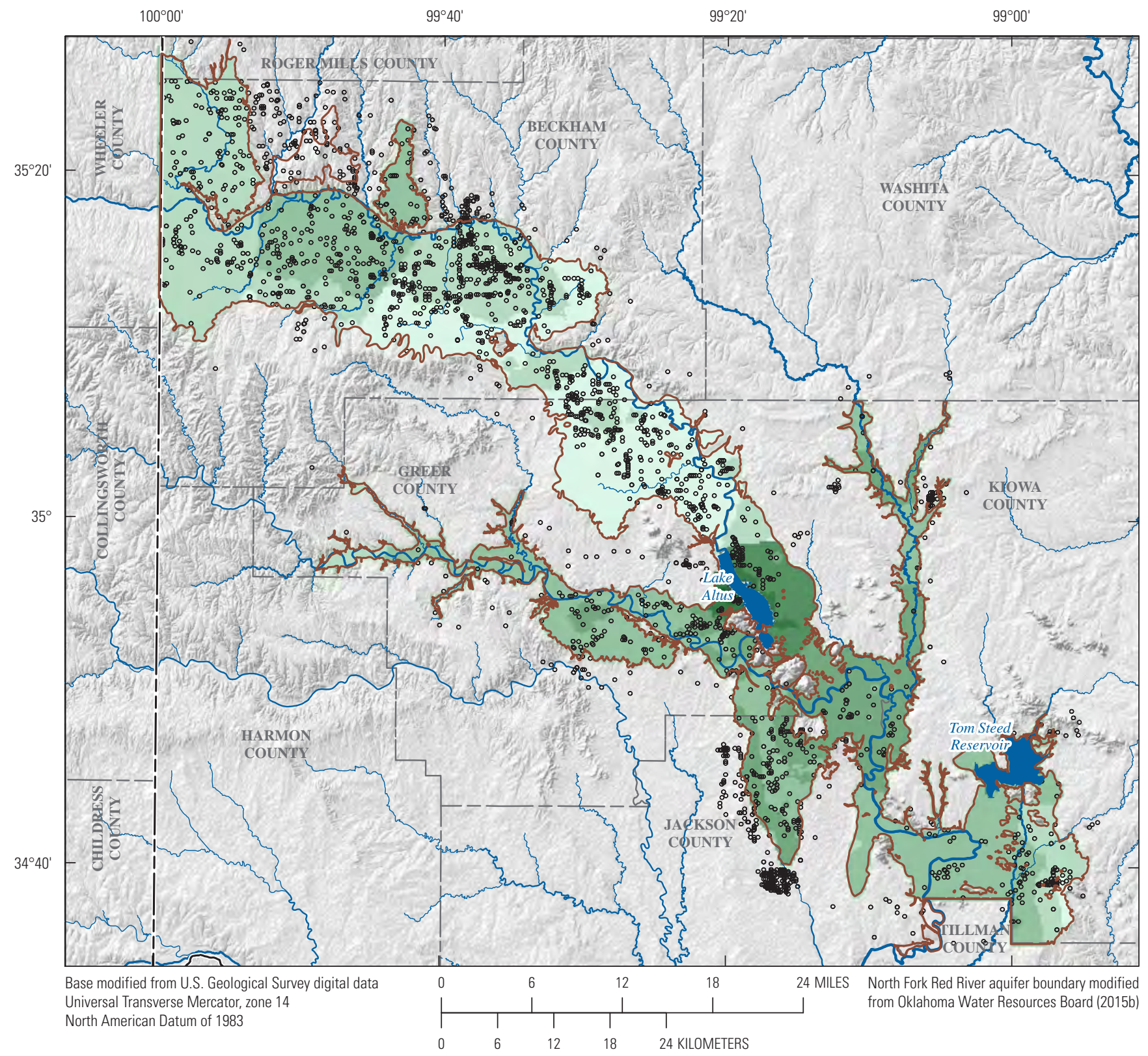

EXPLANATION

North Fork Red River aquifer boundary

Calibrated horizontal hydraulic conductivity (Kh), in feet per day

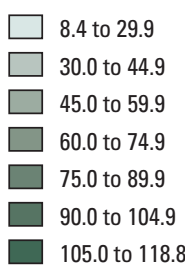

- Lithologic log location (Oklahoma Water Resources Board, 2015b).

Logs shown outside of the North Fork Red River aquifer were not

used to determine $\mathrm{Kh}$, but were used to delineate the aquifer extent.

Figure 36. Horizontal hydraulic conductivity (Kh) for the calibrated numerical groundwater-flow model of the North Fork Red River aquifer, southwest Oklahoma. 


\section{Differences in Numerical Groundwater-Flow Models}

Though the Kent (1980) hydrologic investigation and the one described in this report both used numerical models to simulate groundwater flow, those investigations had a number of differences regarding the study area conceptualization and numerical model inputs. The Kent (1980) numerical model area was $536 \mathrm{mi}^{2}$, which was about 31 percent smaller than the numerical model area described in this report $\left(777 \mathrm{mi}^{2}\right)$. The Kent (1980) numerical model used the Trescott and others (1976) code with a cell size of 2,640 by 2,640 ft, and the investigation described in this report used the updated MODFLOW-NWT code with a cell size of 886 by $886 \mathrm{ft}$, or about one-ninth the area of the Kent (1980) model cells. The conceptual model of Kent (1980) used a mean Kh of about $92 \mathrm{ft} / \mathrm{d}$, whereas the mean Kh determined from the results of the hydrogeologic framework for this investigation was $52 \mathrm{ft} / \mathrm{d}$ (46 ft/d for the calibrated numerical model). Maps of transmissivity from Kent (1980), however, suggest that much smaller values of Kh may have been used in the Kent (1980) calibrated numerical model. The Sy value (0.12) used in the calibrated numerical model described in this report was about half of that used in the Kent (1980) calibrated numerical model (0.246).

Recharge for the numerical model of Kent (1980) was $2.28 \mathrm{in} / \mathrm{yr}$, or 9.38 percent of the Kent (1980) mean annual precipitation (24.28 in/yr); recharge for the calibrated numerical model described in this report was about 122,000 acre-ft/yr (2.94 in/yr over the aquifer area of 497,582 acres, table 14), or 10.1 percent of the mean annual precipitation during 1980-2013 (29.2 in/yr, table 3). Unlike the numerical model described in this report, however, the Kent (1980) numerical model supplemented recharge from precipitation with estimated recharge from irrigation return flow. The Kent (1980) numerical model simulated total streamflow, but the numerical model described in this report simulated only base flow, excepting Lake Altus. Many other differences in the numerical models could be listed, but those listed here were expected to have the greatest influence on simulated groundwater flow and availability in each model.

\section{Groundwater Availability Scenarios}

Three types of predictive scenarios were run on the calibrated numerical model. These scenarios were used to (1) estimate the equal-proportionate-share (EPS) pumping rate that guarantees a minimum 20-, 40-, and 50-year life of the aquifer, (2) quantify the potential effects of projected well withdrawals on groundwater storage over a 50-year period, and (3) simulate the potential effects of a hypothetical (10-year) drought on base flow and groundwater storage. Groundwater storage was calculated by multiplying the Sy (0.12) by the saturated thickness in each active model cell. The inputs and outputs for the groundwater-availability scenarios are available in Smith and others (2017).

\section{Equal Proportionate Share}

EPS scenarios for the North Fork Red River aquifer were run for periods of 20, 40, and 50 years. The 2013 simulated water table from the calibrated numerical model was used as the starting water table in each EPS scenario. Model inputs for recharge, saturated-zone ET, Tom Steed Reservoir stage, and stream inflows to the model active area were configured as the mean of each annual period used in the calibrated numerical model. Annual stress periods were used in these scenarios instead of the monthly stress periods to simplify the analysis and improve model stability. To determine the EPS pumping rate, hypothetical wells were placed in each layer 1 active cell (covering 18 acres) and pumped at the same rate for the duration of the scenario. If at the end of the scenario more than 50 percent of the active cells had a saturated thickness of at least $5 \mathrm{ft}$, the pumping rate was increased by about 35 cubic feet per day ( 1 cubic meter per day). The scenario was repeated until 50 percent of the cells had a saturated thickness of less than $5 \mathrm{ft}$. To account for potential climate variability, this process was repeated with recharge increased and decreased by 10 percent.

The 20-, 40-, and 50-year EPS pumping rates under normal recharge conditions were $0.59,0.52$, and 0.52 acrefoot per acre per year, respectively (fig. 37 , table 15; values rounded to the nearest hundredth). Given the 497,582-acre aquifer area, these rates correspond to annual yields of about 294,000, 259,000, and 259,000 acre-ft/yr, respectively. For the 20-year EPS scenario, decreasing and increasing recharge by 10 percent resulted in a 5-7-percent change in the EPS pumping rate; for the 40- and 50-year EPS scenarios, decreasing and increasing recharge by 10 percent resulted in a 6-8-percent change in the EPS pumping rate (fig. 37, table 15).

Groundwater storage at the end of the 20-year EPS scenario was about 951,000 acre-ft, or about 1,317,000 acre-ft (58 percent) less than the starting EPS scenario storage. This decrease in storage was equivalent to a mean water-level decline of about $22 \mathrm{ft}$. Most areas of the active alluvium near the North Fork Red River, Elk Creek, and Elm Fork Red River remained partially saturated through the end of the EPS scenario because of streambed seepage (fig. 38). Where the terrace was sufficiently thick - about $80 \mathrm{ft}$ or greater-or a shallow hydraulic gradient was present, partial saturation was sustained though the entire EPS scenario (fig. 38). At the end of the 20-year EPS scenario, the greatest remaining saturated thickness was in the network of paleochannels along the Beckham County Fault (fig. 12). Saturated thickness greater than $5 \mathrm{ft}$ also remained along Elk Creek, Sweetwater Creek, Elm Fork Red River, and North Fork Red River (except for the reach between the Carter streamgage [07301500] and Lake Altus), which were sustained by simulated SFR inflows (ELK, 


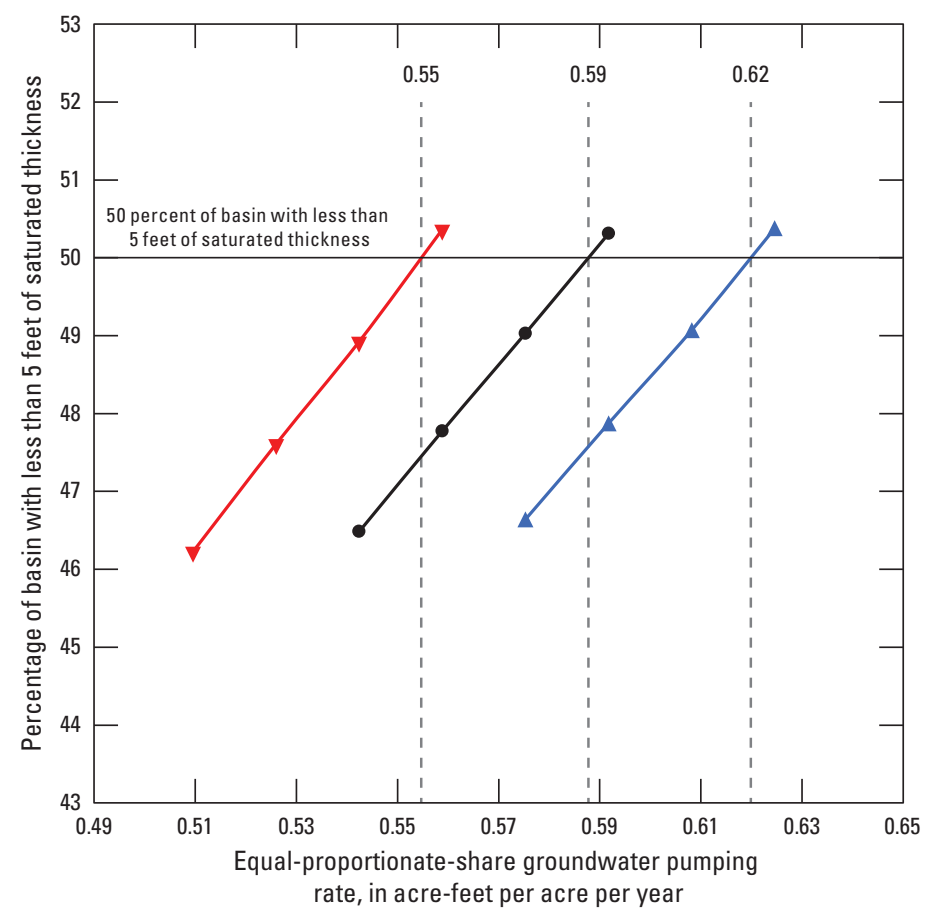

EXPLANATION

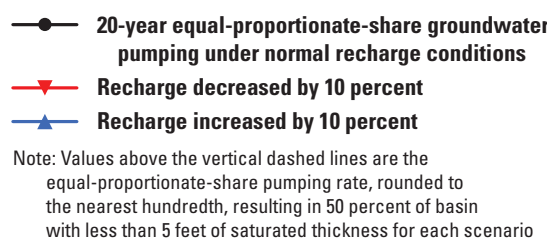

Figure 37. Percentage of the North Fork Red River aquifer with less than 5 feet of saturated thickness after 20 years of continuous equal-proportionate-share groundwater pumping.

Table 15. Equal-proportionate-share (EPS) pumping rates for the North Fork Red River aquifer, southwest Oklahoma.

\begin{tabular}{cccc}
\hline & \multicolumn{3}{c}{$\begin{array}{c}\text { EPS pumping rate } \\
\text { (acre-feet per acre per year) }\end{array}$} \\
\cline { 2 - 4 } (years) & $\begin{array}{c}\text { Recharge } \\
\text { reduced by } \\
\text { 10 percent }\end{array}$ & $\begin{array}{c}\text { Normal } \\
\text { recharge }\end{array}$ & $\begin{array}{c}\text { Recharge } \\
\text { increased by } \\
\text { 10 percent }\end{array}$ \\
\hline 20 & 0.55 & 0.59 & 0.62 \\
40 & 0.49 & 0.52 & 0.56 \\
50 & 0.48 & 0.52 & 0.56 \\
\hline
\end{tabular}

SWEE, EFRR, and NFRR, respectively) (fig. 38). Other terrace areas generally had less than $5 \mathrm{ft}$ of saturated thickness except for areas near the Texas border, where saturated thickness was sustained by GHB cells, and near Lake Altus and Tom Steed Reservoir, where saturated thickness was sustained by lakebed seepage (fig. 38).

At the end of the 20-year EPS scenario, mean annual base-flow declines of 100 and 86 percent occurred at the Carter streamgage (07301500) and Headrick streamgage (07305000), respectively, compared to the start of the EPS scenario. The decrease in base flow was greater upstream from Lake Altus because of the smaller inflows to Sweetwater Creek and the North Fork Red River from Texas compared to inflows to the Elm Fork Red River and Elk Creek. The aquifer water table was below the bottom of the streams during most of the EPS scenario, resulting in streambed seepage outflows from the stream to the aquifer (losing streams). With the exception of streams receiving base-flow inflows from outside the active model area, the majority of streams in the study area were dry (base flow of $0.0-5.0 \mathrm{ft}^{3} / \mathrm{s}$ ) at the end of the 20-year EPS scenario (fig. 38).

For the 40-year and 50-year EPS scenarios, most (90 percent) of the dewatering of the aquifer occurred during the first 20 years (fig. 39). During that time, annual EPS pumping decreased in the numerical model as the thinner parts of the aquifer went dry. Annual storage changes decreased as annual EPS pumping decreased, and approximate steady-state conditions were reached after about 30 years (fig. 39). These approximate steady-state conditions explain why the 40and 50-year EPS pumping rates are the same. Groundwater storage at the end of the 50-year EPS scenario was about 948,000 acre-ft, or about 1,320,000 acre-ft (58 percent) less than the starting EPS scenario storage.

Lake Altus storage was reduced to zero after 6-7 years of EPS pumping in each scenario. Surface-water inflow from the North Fork Red River was the primary inflow to Lake Altus (fig. 33), so Lake Altus storage quickly decreased when the North Fork Red River ceased flowing. When the EPS scenarios were run without simulating Lake Altus, the EPS decreased by less than 0.1 acre-foot per acre per year for each scenario. 


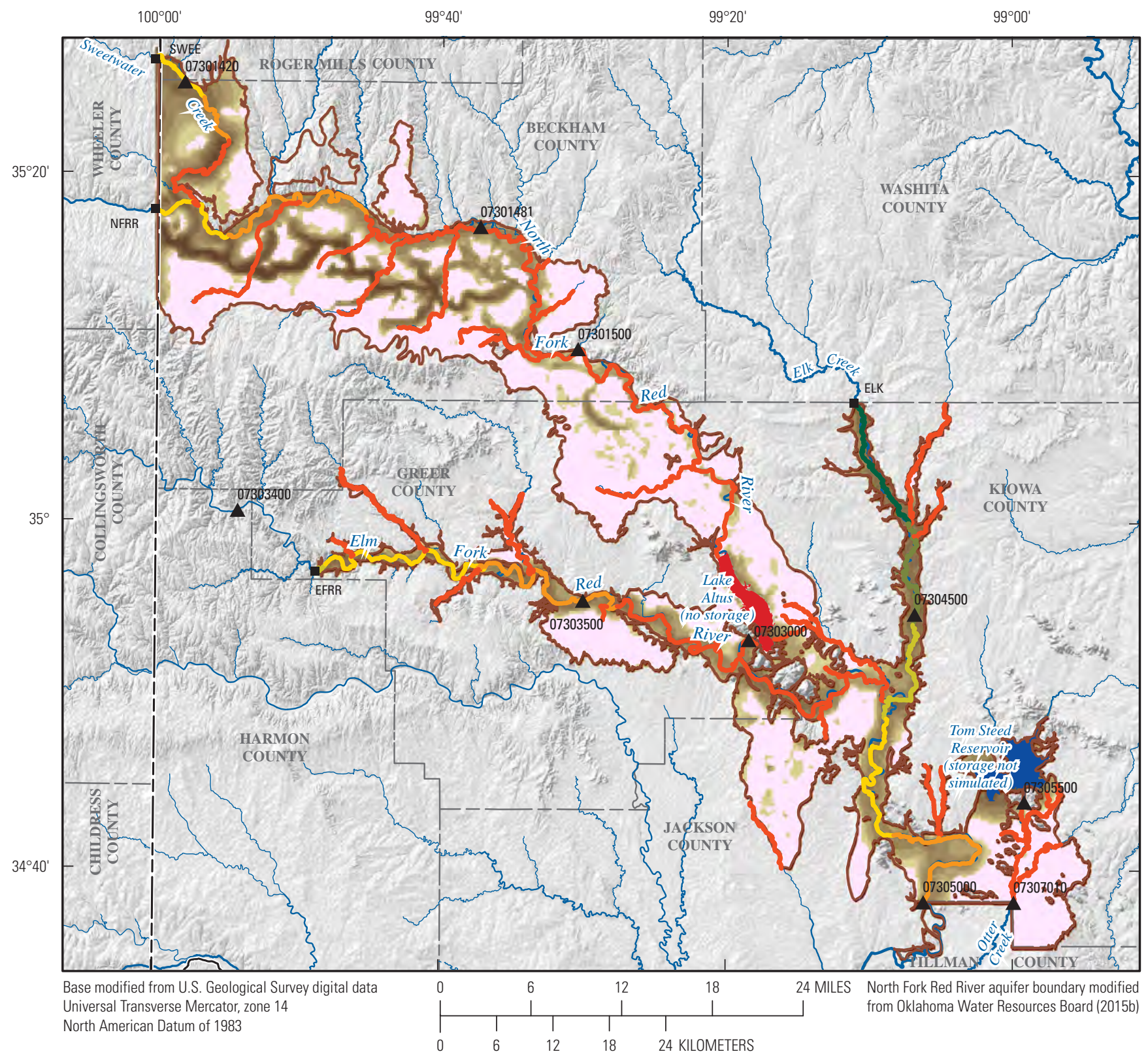

EXPLANATION

North Fork Red River aquifer boundary

Saturated thickness, in feet, after $\mathbf{2 0}$ years of equalproportionate-share groundwater pumping

Base flow, in cubic feet per second, after 20 years of equal-

$\square \quad 0.0$ to 5.0 proportionate-share groundwater pumping

0.0 to 5.0

5.1 to 10.0

$\square \quad 10.1$ to 15.0

10.1 to 15.0

$\square \quad 15.1$ to 25.0

- 15.1 to 20.0

25.1 to 40.0

40.1 to 60.0

60.1 to 85.0

85.1 to 130.4

20.1 to 25.0

25.1 to 32.5

A Streamgage, with station number

- Streamflow-routing inflow, with name

Figure 38. Simulated saturated thickness and base flow after 20 years of continuous equal-proportionate-share groundwater pumping in the North Fork Red River aquifer, southwest Oklahoma. 

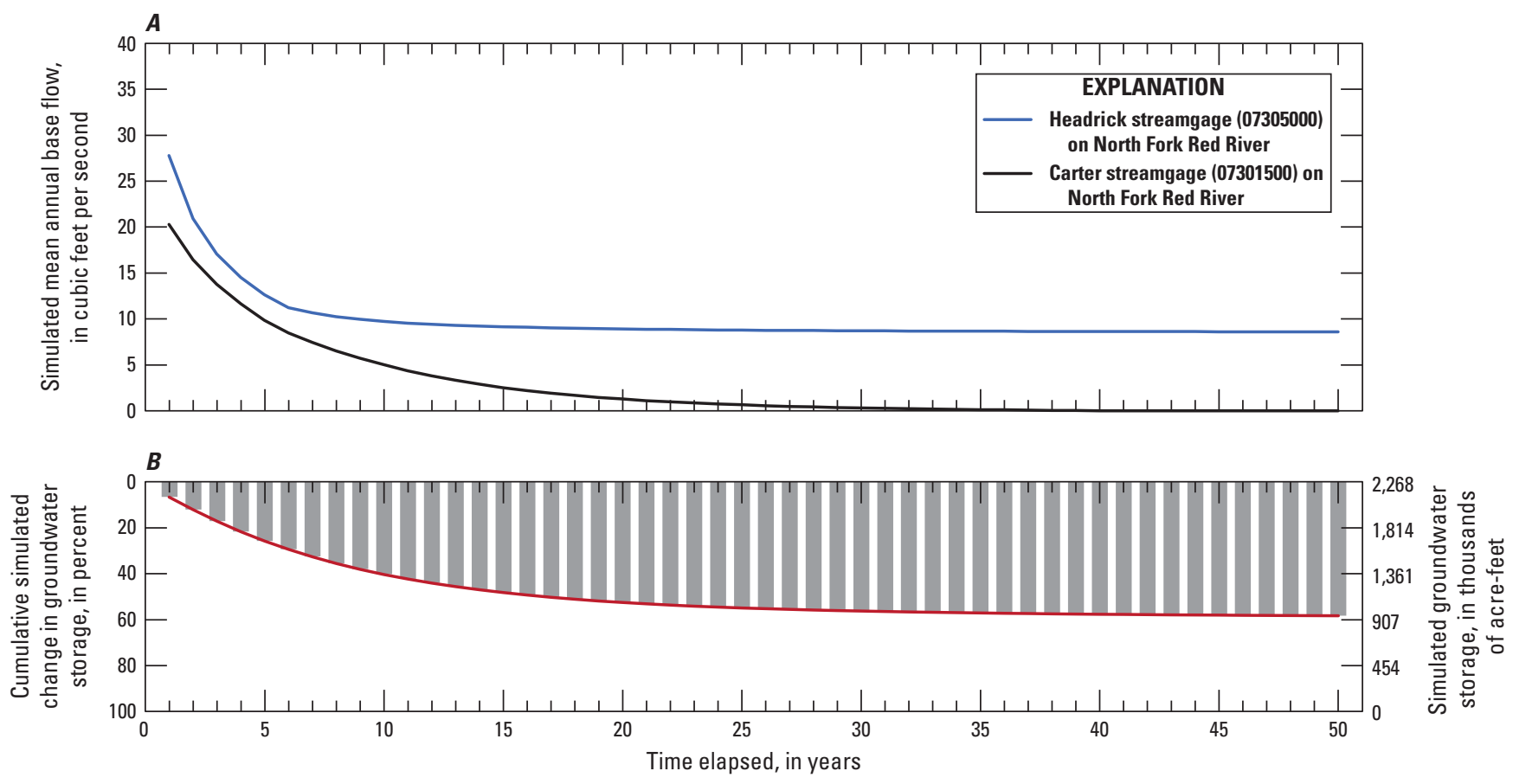

EXPLANATION

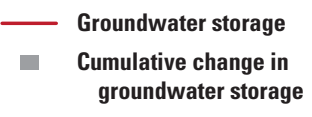

Figure 39. Changes in $A$, simulated base flow and $B$, simulated groundwater storage during 50 years of continuous equalproportionate-share groundwater pumping in the North Fork Red River aquifer, southwest Oklahoma.

\section{Projected (50-Year) Pumping}

Projected 50-year pumping scenarios were used to simulate the effects of selected well withdrawal rates on groundwater storage of the North Fork Red River aquifer and base flows in the North Fork Red River upstream from Lake Altus. The effects of well withdrawals were evaluated by comparing changes in groundwater storage (and base flow) between four 50-year scenarios using (1) no groundwater pumping, (2) mean pumping rates for the study period (1980-2013), (3) 2013 pumping rates, and (4) increasing demand pumping rates. The increasing demand pumping rates assumed a 20.4-percent increase in pumping over 50 years based on 2010-60 demand projections for southwest Oklahoma (OWRB, 2012b). The projected water-use scenarios began in 1980 and ran until 2029. The scenarios did not begin in 2013 and run until 2062 because the calibrated numerical model ended in drought conditions, and the low initial (2013) groundwater storage caused all four scenarios to show nonintuitive gradual increases in groundwater storage. Model stresses were configured as the mean of each monthly stress period from the calibrated model, and the scenarios assumed that future climate conditions were similar to those of the 1980-2013 study period.

Groundwater storage after 50 years with no pumping was about 2,606,000 acre-ft, or 137,000 acre-ft (5.5 percent) greater than the initial groundwater storage; this groundwater storage increase is equivalent to a mean water-level increase of $2.3 \mathrm{ft}$ (fig. 40, table 16). Groundwater storage after 50 years with the mean pumping rate for the study period (19802013) was about 2,476,000 acre-ft, or about 7,000 acre-ft ( 0.3 percent) greater than the initial groundwater storage; this groundwater storage increase is equivalent to a mean water-level increase of $0.1 \mathrm{ft}$ (fig. 40, table 16). Groundwater storage at the end of the 50-year period with 2013 pumping rates was about 2,398,000 acre-ft, or about 70,000 acre-ft (2.8 percent) less than the initial storage; this groundwater storage decrease is equivalent to a mean water-level decline of $1.2 \mathrm{ft}$ (fig. 40, table 16). Groundwater storage at the end of the 50-year period with increasing demand pumping rates was about 2,361,000 acre-ft, or about 107,000 acre-ft (4.3 percent) less than the initial storage; this groundwater storage decrease is equivalent to a mean water-level decline of $1.8 \mathrm{ft}$ (fig. 40, table 16). 

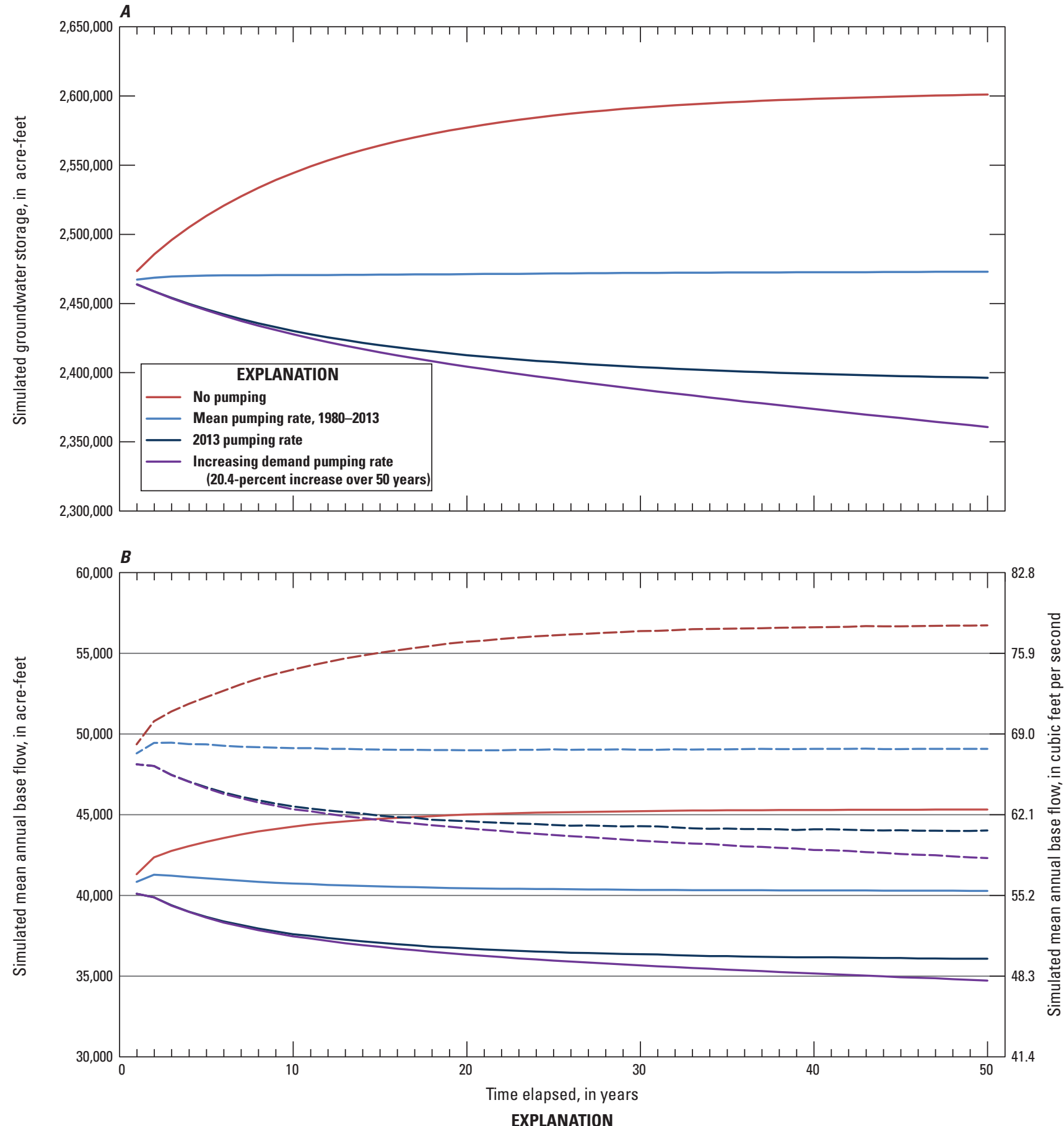

EXPLANATION

\begin{tabular}{ccc}
$--\begin{array}{c}\text { North Fork Red River inflow to Lake Altus, } \\
\text { no pumping }\end{array}$ & $--\begin{array}{c}\text { North Fork Red River inflow to Lake Altus, } \\
2013 \text { pumping rate }\end{array}$ \\
$\begin{array}{c}\text { Carter streamgage (07301500) on North Fork } \\
\text { Red River, no pumping }\end{array}$ & $\begin{array}{c}\text { Carter streamgage (07301500) on North Fork } \\
\text { Red River, 2013 pumping rate }\end{array}$ \\
$--\begin{array}{c}\text { North Fork Red River inflow to Lake Altus, } \\
\text { mean pumping rate, 1980-2013 }\end{array}$ & $\begin{array}{c}\text { North Fork Red River inflow to Lake Altus, } \\
\text { increasing demand pumping rate }\end{array}$ \\
\hline $\begin{array}{c}\text { Carter streamgage (07301500) on North Fork } \\
\text { Red River, mean pumping rate, 1980-2013 }\end{array}$ & $\begin{array}{c}\text { (20.4-percent increase over } 50 \text { years) } \\
\text { Carter streamgage (07301500) on North Fork } \\
\text { Red River, increasing demand pumping rate }\end{array}$ \\
& (20.4-percent increase over 50 years)
\end{tabular}

Figure 40. A, Simulated groundwater storage and $B$, simulated mean annual base flow through 50 years of groundwater pumping at selected rates in the North Fork Red River aquifer, southwest Oklahoma. 
Table 16. Changes in groundwater storage and mean annual base flow after 50 years of groundwater pumping at selected rates for the North Fork Red River aquifer, southwest Oklahoma.

[Values reported may vary from those calcluated using this table because of rounding errors]

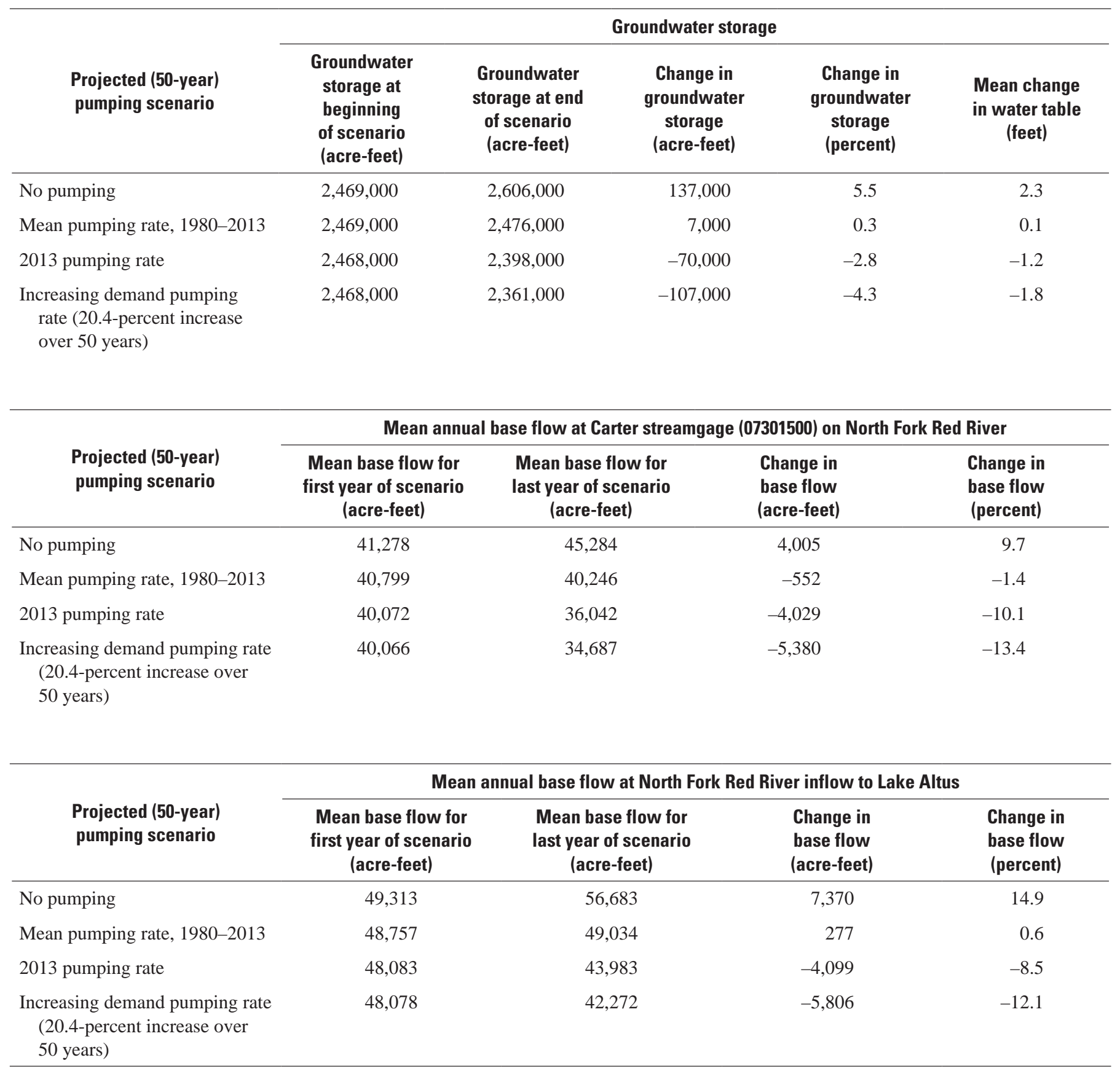


Mean annual base flow simulated at the Carter streamgage (07301500) on North Fork Red River increased by about 4,000 acre-ft (10 percent) after 50 years with no pumping and decreased by about 5,400 acre-ft (13 percent) after 50 years with increasing demand pumping rates (fig. 40, table 16). Mean annual base flow simulated at the North Fork Red River inflow to Lake Altus increased by about 7,400 acre-ft (15 percent) after 50 years with no pumping and decreased by about 5,800 acre-ft (12 percent) after 50 years with increasing demand pumping rates (fig. 40, table 16).

\section{Hypothetical (10-Year) Drought}

A hypothetical 10-year drought scenario was used to simulate the effects of a prolonged period of reduced recharge on groundwater storage and Lake Altus stage and storage. The period of January 1984 to December 1993, which had base flows similar to the mean annual base flow for the study period, was chosen as the simulated drought period. Drought effects were quantified by comparing the results of the drought scenario to those of the calibrated numerical model (no drought). To simulate the hypothetical drought, recharge in the calibrated numerical model was reduced by 50 percent during the simulated drought period (1984-1993). Upstream inflows to the North Fork Red River and tributaries were reduced by 37 percent, which was the mean decrease in annual base flow during the drought of years 1976-81 as compared to the study period 1980-2013 at the Carter (07301500) and Carl (07303400) streamgages (Barlow and others, 2015; USGS, 2015a). The rates of direct lake-surface precipitation (a small component of the lake inflows, fig. 33A), evaporation, and nonstream runoff to Lake Altus were unchanged from the calibrated numerical model. Withdrawals from lake storage also were unchanged, with the exception of monthly withdrawals in six stress periods (in months 121-156) that were reduced by 25 percent to fix model instability problems caused by near-zero storage in Lake Altus.

Groundwater storage at the end of the drought period (month 120) was about 2,271,000 acre-ft, or about 426,000 acre-ft (15.8 percent) less than the groundwater storage of the calibrated numerical model (fig. 41). This decrease in groundwater storage is equivalent to a mean watertable-altitude decline of $7.1 \mathrm{ft}$.

The largest water-level declines (as great as $49 \mathrm{ft}$ ) occurred in the terrace areas most upgradient from the North Fork Red River and tributaries. Excluding areas near Lake Altus, Tom Steed Reservoir, and the Texas border, groundwater storage in the upgradient terrace was supplied entirely by recharge, so decreases in recharge have substantial effects on terrace water levels. The decreased saturated thickness in some areas of the terrace caused a reduction in simulated well withdrawals as compared to the calibrated numerical model. The saturated thickness of areas near the North Fork Red River and major tributaries changed little during the hypothetical drought, but the simulated base flow in streams in those areas decreased rapidly. After 12 months of the hypothetical drought, simulated base flows at the Sweetwater (07301420), Carter (07301500), and Headrick (07305000) streamgages had all decreased by greater than 30 percent as compared to the calibrated numerical model (fig. 42). At the end of the 10-year hypothetical drought period, simulated base flows at the Sweetwater (07301420), Carter (07301500), Headrick (07305000), and Snyder (07307010) streamgages had decreased by about 37, 61, 44, and 45 percent, respectively (fig. 42).

Substantial declines in the Lake Altus stage began around month 30 (fig. 43) in conjunction with base-flow decreases of more than 50 percent at the Carter streamgage (07301500) (fig. 42B). These lake-stage declines outpaced water-level declines in the surrounding aquifer. During the drought, simulated storage in seven monthly stress periods (in July and August between months 55 and 128) decreased below the dead pool storage of 633 acre-ft (U.S. Bureau of Reclamation, 2015b). The minimum Lake Altus storage simulated during the drought period was 403 acre-ft in month 116 (fig. 43), which was a decline of 92 percent from the nondrought storage. The drought effects persisted years after the end of the simulated drought, and the minimum Lake Altus storage during the study period (350 acre-ft) was simulated in month 129 (fig. 43). Reduced base flows in the North Fork Red River were the primary cause of simulated Lake Altus storage declines.

Because Lake Altus storage approached zero during the summer months of the hypothetical 10-year drought (fig. 43), the numerical model automatically reduced withdrawal rates from Lake Altus by about 12 percent. After the end of the hypothetical 10-year drought period, withdrawal rates from Lake Altus remained about 10 percent lower than nondrought conditions until August 2011. From August 2011 to June 2015, water was not withdrawn from Lake Altus for irrigation use at LAID, and the observed lake stage was at or below 1,536 ft (U.S. Bureau of Reclamation, 2015b) (fig. 30). At this stage, Lake Altus storage was about 30,000 acre-ft (12 percent of the normal-pool storage capacity) (fig. 30). If this storage threshold for withdrawals was implemented during the hypothetical 10-year drought scenario, withdrawals from Lake Altus would not occur during 60 percent of summer months, when irrigation demand was largest. 


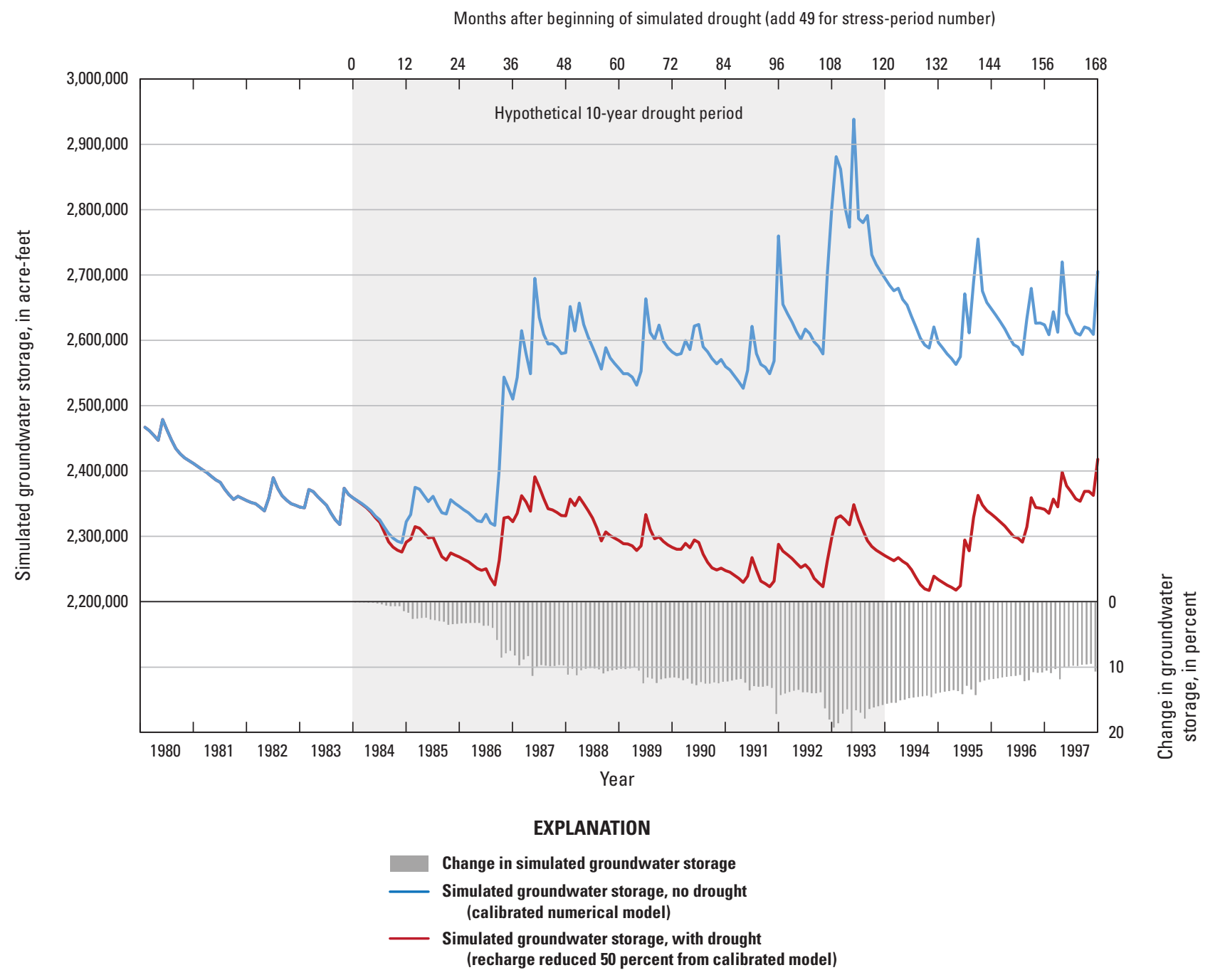

Figure 41. Changes in groundwater storage resulting from a hypothetical 10-year drought (1984-93) for the North Fork Red River aquifer, $1980-97$. 
A. Sweetwater streamgage (07301420) on Sweetwater Creek

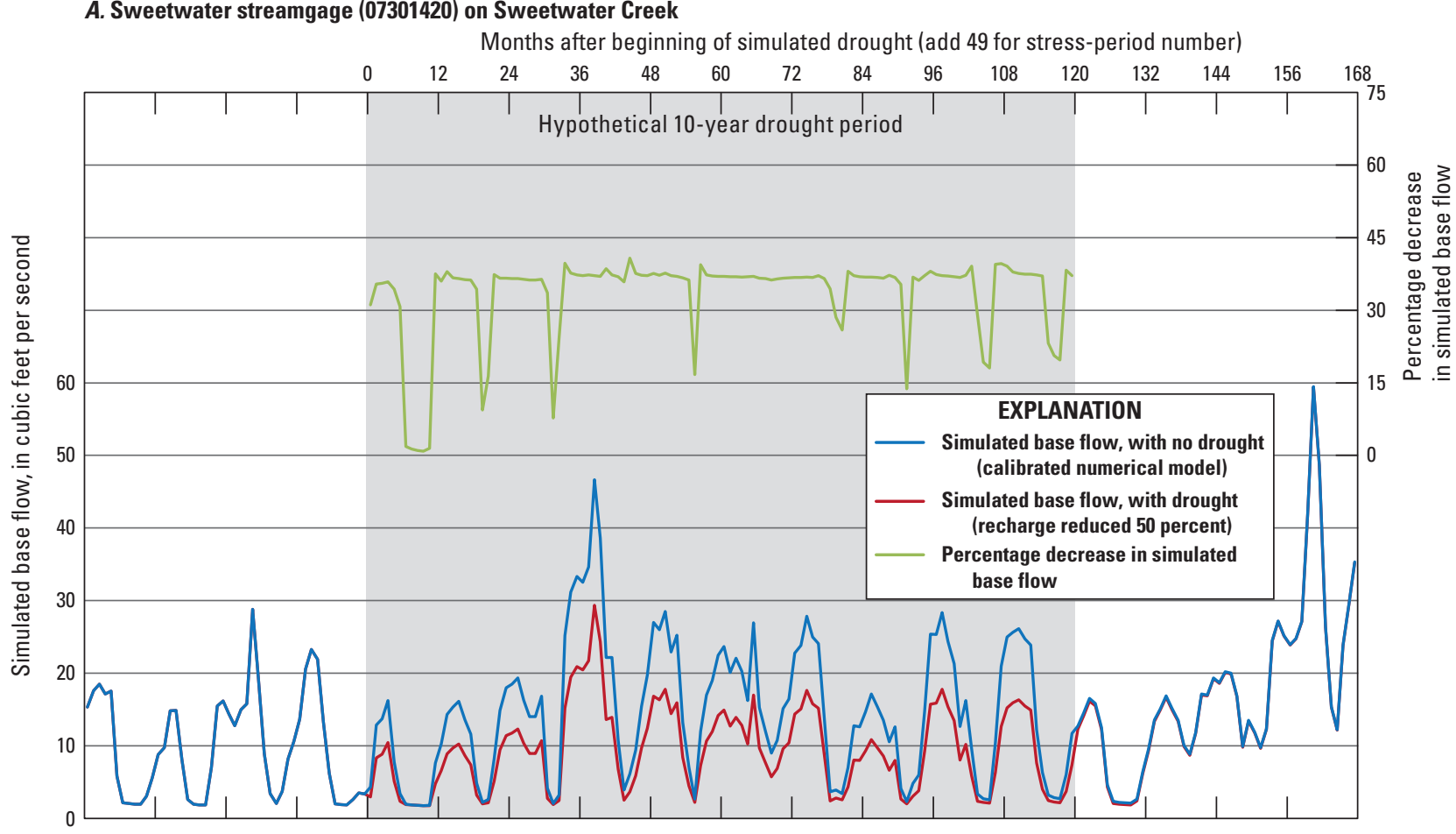

B. Carter streamgage (07301500) on North Fork Red River

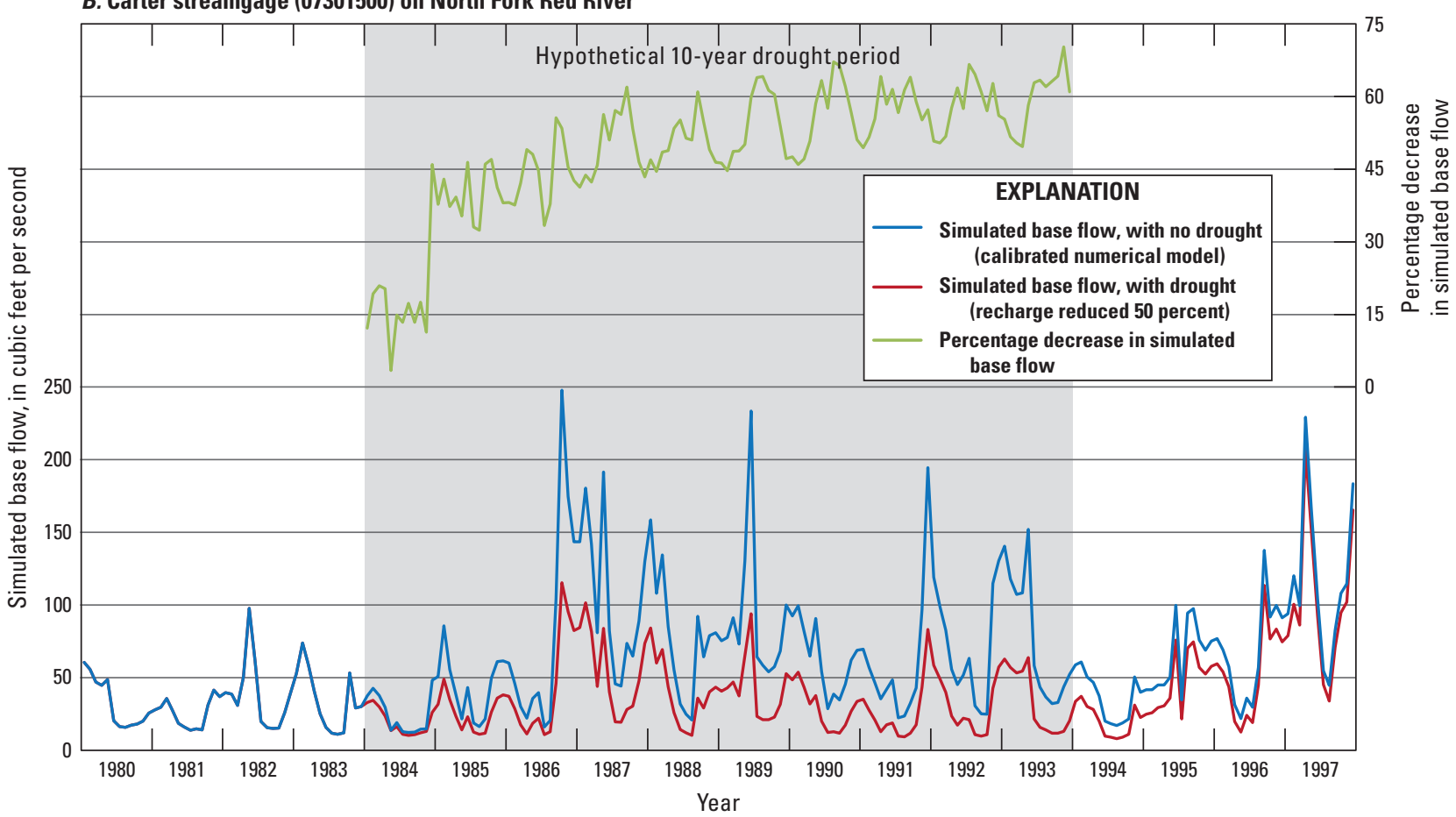

Figure 42. Changes in simulated base flow at $A$, Sweetwater streamgage (07301420) on Sweetwater Creek; $B$, Carter streamgage (07301500) on North Fork Red River; $C$, Headrick streamgage (07305000) on North Fork Red River; and $D$, Snyder streamgage (07307010) on Otter Creek resulting from a hypothetical 10-year drought (1984-93) for the North Fork Red River aquifer, 1980-97. 
C. Headrick streamgage (07305000) on North Fork Red River
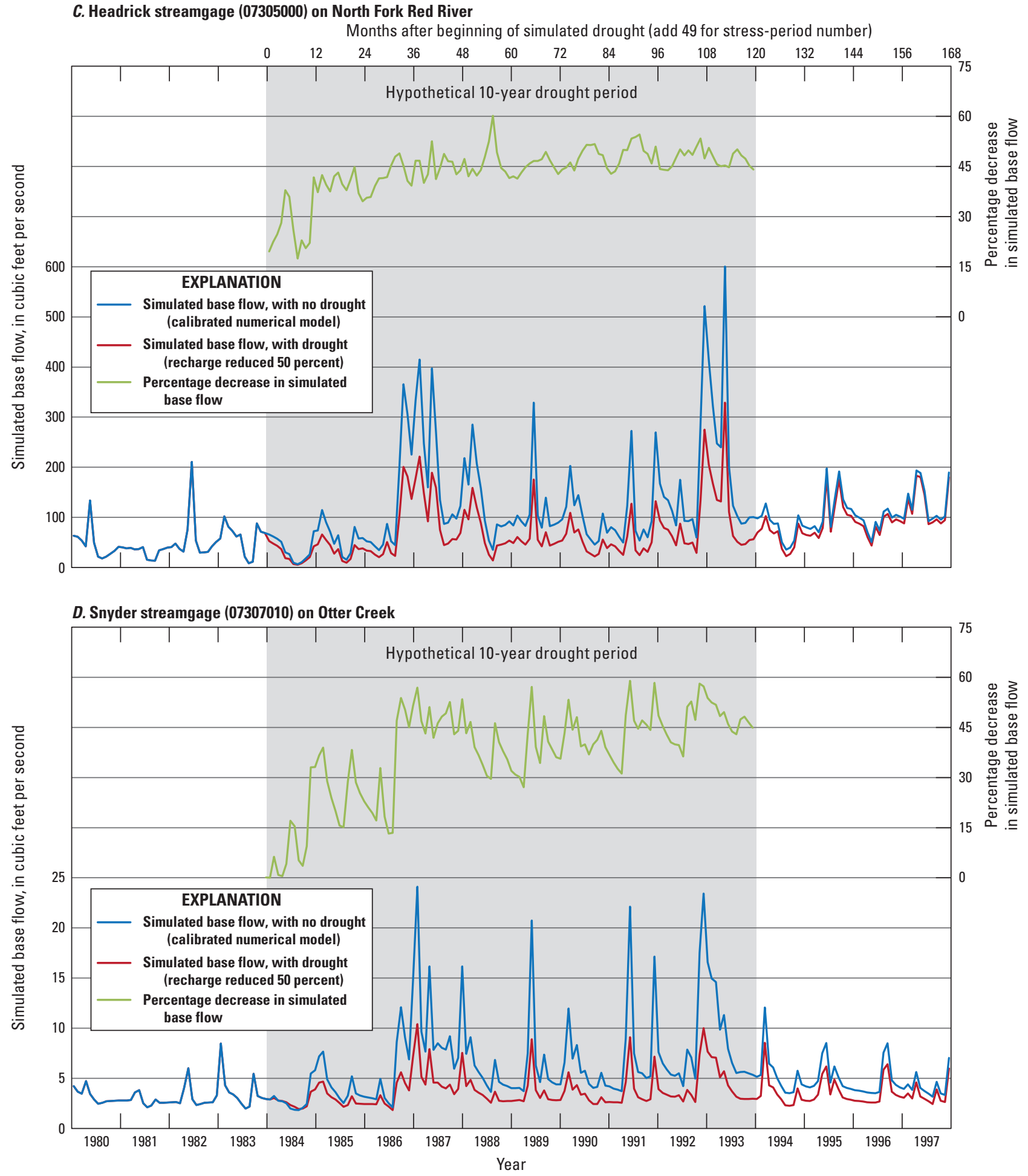

Figure 42. Changes in simulated base flow at $A$, Sweetwater streamgage (07301420) on Sweetwater Creek; $B$, Carter streamgage (07301500) on North Fork Red River; $C$, Headrick streamgage (07305000) on North Fork Red River; and $D$, Snyder streamgage (07307010) on Otter Creek resulting from a hypothetical 10-year drought (1984-93) for the North Fork Red River aquifer, 1980-97.-Continued 

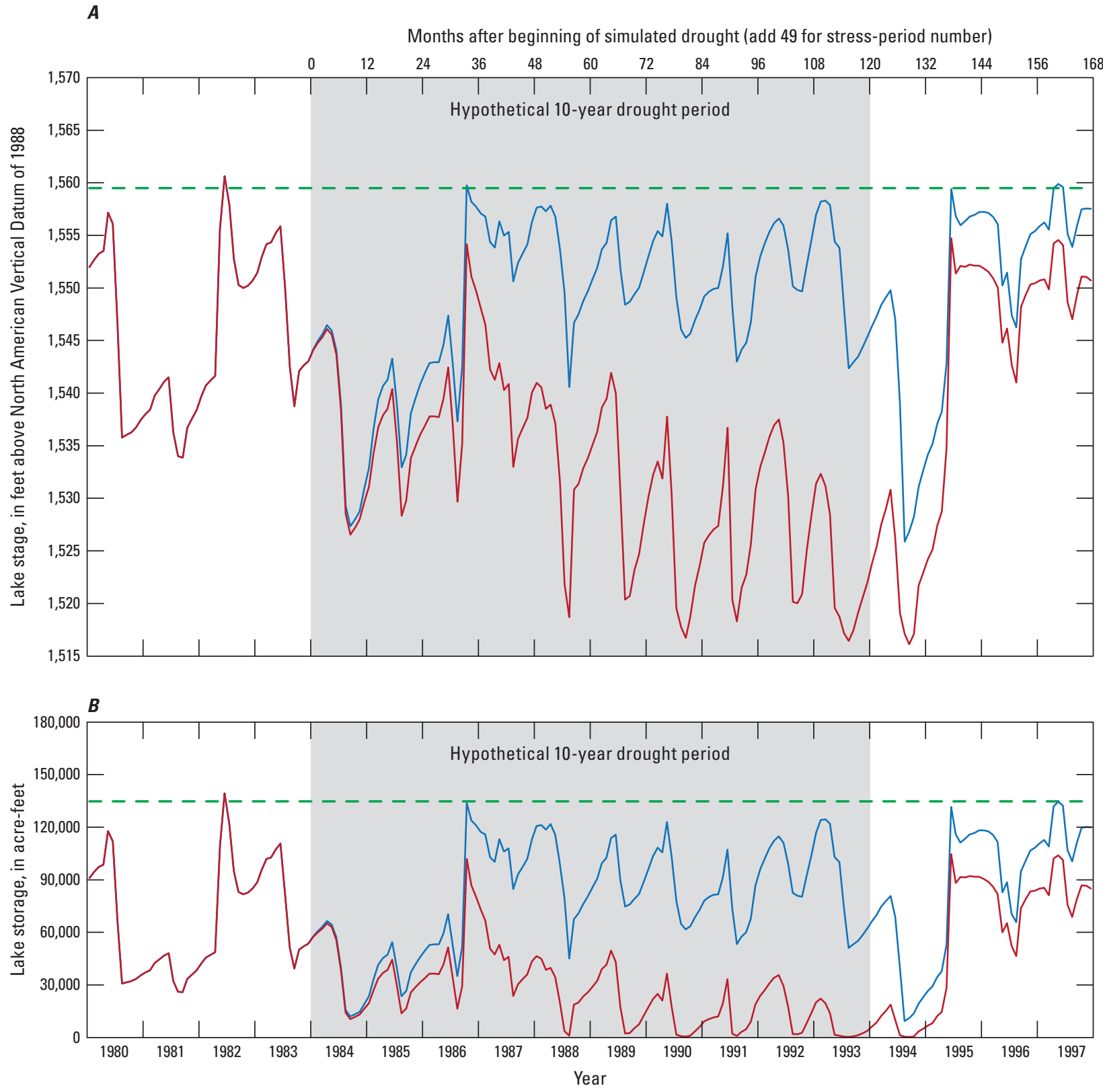

EXPLANATION

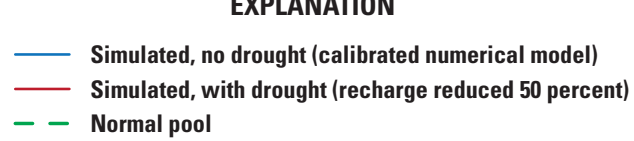

Figure 43. Changes in A, Lake Altus stage and B, Lake Altus storage resulting from a hypothetical 10-year drought (1984-93) for the North Fork Red River aquifer, 1980-97. 


\section{Model Limitations}

Some assumptions and simplifications were necessary in the simulation of groundwater flow. The use of the MODFLOW code required the assumptions that groundwater flows are governed by Darcy's Law (Darcy, 1856), water is incompressible and of uniform density, and the aquifer hydrogeology can be simulated appropriately by the cell size and number of layers present. Computing and time limitations prevented the use of cell sizes that could better represent the true variability of hydrogeologic characteristics; therefore, results generated by the model may be more applicable to a regional, rather than local, area.

An uneven spatial and temporal distribution of water-table-altitude observations caused data gaps in the calibration data. Though the simulated water table in areas with fewer observations is in an expected water-tablealtitude range, more site-specific and local calibration target data could facilitate a more detailed characterization of watertable conditions. Additionally, base-flow gain to the North Fork Red River is based on the simulated water table and may not be well represented in locations where water-tablealtitude observation data were relatively sparse.

The stream network used in the numerical model is a simplification of the actual stream geometry and hydraulic properties. Refined measurement of the stream channel width and streambed conductance at the local scale might improve the numerical model calibration because these factors control the amount of streambed seepage exchange with the aquifer. The numerical model was calibrated primarily to base-flow estimates; therefore, collection of more streamflow and base-flow data during other hydrologic conditions also could further reduce uncertainty in local-scale simulation results.

Lake Altus inflows (base flows) simulated by the numerical model are likely to be of interest to surface-water resource managers. Because no streamgages are located between Carter (07301500) and Lake Altus (a distance of about 27 river miles), additional streambed seepage may occur in this reach that was not represented in the calibrated numerical model. Additional long-term streamgage data near the lake inflow point and seasonal synoptic base-flow measurements over a range of hydrologic conditions would be needed to increase confidence that the calibrated numerical model was adequately reproducing observed base flows in that reach.

Exact amounts of annual groundwater use are unknown because groundwater wells are not metered, and groundwateruse data are based on estimates submitted to the OWRB by permit holders. Additionally, groundwater use by domestic wells, though assumed to be relatively small, was not included in the numerical model.

\section{Summary}

On September 8, 1981, the Oklahoma Water Resources Board (OWRB) established regulatory limits on the maximum annual yield of groundwater (343,042 acre-feet per year) and equal-proportionate-share (EPS) pumping rate (1.0 acre-foot per acre per year) for the North Fork Red River aquifer. The maximum annual yield and EPS were based on a hydrologic investigation that used a numerical groundwater-flow model to evaluate the effects of potential groundwater withdrawals on groundwater availability in the North Fork Red River aquifer. The OWRB is statutorily required (every 20 years) to update the hydrologic investigation on which the maximum annual yield and EPS were based. Because 20 years have elapsed since the final order was issued, the U.S. Geological Survey, in cooperation with the OWRB, conducted an updated hydrologic investigation and evaluated the effects of potential groundwater withdrawals on groundwater flow and availability in the North Fork Red River aquifer in Oklahoma. This report describes a hydrologic investigation of the North Fork Red River aquifer that includes an updated summary of the aquifer hydrogeology. As part of this investigation, groundwater flow and availability were simulated by using a numerical groundwater-flow model.

The North Fork Red River aquifer in Beckham, Greer, Jackson, Kiowa, and Roger Mills Counties in Oklahoma is composed of about 777 square miles (497,582 acres) of alluvium and terrace deposits along the North Fork Red River and tributaries, including Sweetwater Creek, Elk Creek, Otter Creek, and Elm Fork Red River. The North Fork Red River is the primary source of surface-water inflow to Lake Altus, which overlies the North Fork Red River aquifer. Lake Altus is a U.S. Bureau of Reclamation reservoir with the primary purpose of supplying irrigation water to the Lugert-Altus Irrigation District. The mean annual precipitation and the mean annual temperature in the study area for the period of record 1895-2015 were about 27.6 inches per year and about 61.2 degrees Fahrenheit, respectively. The mean annual temperature was about 0.4 degree Fahrenheit greater and the mean annual precipitation was about 1.6 inches per year greater for the study period 1980-2013 compared to the period of record. The mean annual reported groundwater use was 15,279 acre-feet per year for the period of record 1967-2013 and 15,859 acre-feet per year for the period 1980-2013. The year with the greatest reported groundwater use (26,714 acrefeet) was 2011. Though three of the four greatest individual users of groundwater were municipalities, irrigation was the major groundwater-use type for the period of record 1967-2013.

A hydrogeologic framework was developed for the North Fork Red River aquifer and included a definition of the aquifer extent and potentiometric surface, as well as a description of the textural and hydraulic properties of aquifer materials. The estimated horizontal hydraulic conductivity determined for lithologic logs in the North Fork Red River aquifer ranged 
from 3 to 97 feet per day, with a mean of 52 feet per day. Based on available multi-well aquifer test data and published studies, a mean specific yield value of 0.12 was estimated for the North Fork Red River aquifer. The hydrogeologic framework was used in the construction of a numerical groundwater-flow model of the North Fork Red River aquifer described in this report.

A conceptual model of aquifer inflows and outflows was developed for the North Fork Red River aquifer to constrain the construction and calibration of a numerical groundwaterflow model that reasonably represented the groundwaterflow system. The conceptual-model water budget estimated mean annual inflows to and outflows from the North Fork Red River aquifer for the period 1980-2013 and included a sub-accounting of mean annual inflows and outflows for the portions of the aquifer that were upgradient and downgradient from Lake Altus. Recharge is the predominant inflow to the North Fork Red River aquifer. Based on estimated annual recharge rates from published studies and selected methods, the mean annual recharge rate to the North Fork Red River aquifer for the period 1980-2013 was estimated to be about 2.77 inches per year or 9.5 percent of the mean annual precipitation (29.2 inches per year) for the same period. This 1980-2013 mean annual recharge rate is equivalent to a mean annual recharge volume of about 115,000 acre-feet per year. Streambed seepage is the predominant outflow from the North Fork Red River aquifer. The annual net streambed seepage upgradient from Lake Altus was estimated to be 27,824 acre-feet per year, and the annual net streambed seepage downgradient from Lake Altus was estimated to be 44,010 acre-feet per year.

The numerical groundwater-flow model simulated the period 1980-2013 and was calibrated to water-table-altitude observations at selected wells, monthly base flow at selected streamgages, net streambed seepage as estimated for the conceptual model, and Lake Altus stage. Groundwateravailability scenarios were performed by using the calibrated numerical groundwater-flow model to (1) estimate the EPS pumping rate that guarantees a minimum 20-, 40-, and 50-year life of the aquifer, (2) quantify the potential effects of projected well withdrawals on groundwater storage over a 50-year period, and (3) simulate the potential effects of a hypothetical (10-year) drought on base flow and groundwater storage. The results of the groundwater-availability scenarios could be used by the OWRB to reevaluate the maximum annual yield of groundwater from the North Fork Red River aquifer.

EPS scenarios for the North Fork Red River aquifer were run for periods of 20, 40, and 50 years. The 20-, 40-, and 50-year EPS pumping rates under normal recharge conditions were $0.59,0.52$, and 0.52 acre-foot per acre per year, respectively. Given the 497,582-acre aquifer area, these rates correspond to annual yields of about 294,000, 259,000, and 259,000 acre-feet per year, respectively. For the 20-year EPS scenario, decreasing and increasing recharge by 10 percent resulted in a 5-7-percent change in the EPS pumping rate; for the 40- and 50-year EPS scenarios, decreasing and increasing recharge by 10 percent resulted in a $6-8$-percent change in the EPS pumping rate. Groundwater storage at the end of the 20-year EPS scenario was about 951,000 acre-feet, or about 1,317,000 acre-feet (58 percent) less than the starting EPS scenario storage. This decrease in storage was equivalent to a mean water-level decline of about 22 feet. Most areas of the active alluvium near the North Fork Red River, Elk Creek, and Elm Fork Red River remained partially saturated through the end of the EPS scenario because of streambed seepage. Lake Altus storage was reduced to zero after 6-7 years of EPS pumping in each scenario.

Projected 50-year pumping scenarios were used to simulate the effects of selected well withdrawal rates on groundwater storage of the North Fork Red River aquifer and base flows in the North Fork Red River upstream from Lake Altus. The effects of well withdrawals were evaluated by comparing changes in groundwater storage and base flow between four 50-year scenarios using (1) no groundwater pumping, (2) mean pumping rates for the study period (19802013), (3) 2013 pumping rates, and (4) increasing demand pumping rates. The increasing demand pumping rates assumed a 20.4-percent increase in pumping over 50 years based on 2010-60 demand projections for southwest Oklahoma.

Groundwater storage after 50 years with no pumping was about 2,606,000 acre-feet, or 137,000 acre-feet (5.5 percent) greater than the initial groundwater storage; this groundwater storage increase is equivalent to a mean water-level increase of 2.3 feet. Groundwater storage after 50 years with the mean pumping rate for the study period (1980-2013) was about 2,476,000 acre-feet, or about 7,000 acre-feet (0.3 percent) greater than the initial groundwater storage; this groundwater storage increase is equivalent to a mean water-level increase of 0.1 foot. Groundwater storage at the end of the 50 -year period with 2013 pumping rates was about 2,398,000 acrefeet, or about 70,000 acre-feet (2.8 percent) less than the initial storage; this groundwater storage decrease is equivalent to a mean water-level decline of 1.2 feet. Groundwater storage at the end of the 50-year period with increasing demand pumping rates was about 2,361,000 acre-feet, or about 107,000 acrefeet (4.3 percent) less than the initial storage; this groundwater storage decrease is equivalent to a mean water-level decline of 1.8 feet. Mean annual base flow simulated at the Carter streamgage (07301500) on North Fork Red River increased by about 4,000 acre-feet (10 percent) after 50 years with no pumping and decreased by about 5,400 acre-feet (13 percent) after 50 years with increasing demand pumping rates. Mean annual base flow simulated at the North Fork Red River inflow to Lake Altus increased by about 7,400 acre-feet (15 percent) after 50 years with no pumping and decreased by about 5,800 acre-feet (12 percent) after 50 years with increasing demand pumping rates. 
A hypothetical 10-year drought scenario was used to simulate the effects of a prolonged period of reduced recharge on groundwater storage and Lake Altus stage and storage. Drought effects were quantified by comparing the results of the drought scenario to those of the calibrated numerical model (no drought). To simulate the hypothetical drought, recharge in the calibrated numerical model was reduced by 50 percent during the simulated drought period (1984-93). Groundwater storage at the end of the drought period was about 2,271,000 acre-feet, or about 426,000 acrefeet (15.8 percent) less than the groundwater storage of the calibrated numerical model. This decrease in groundwater storage is equivalent to a mean water-table-altitude decline of 7.1 feet. At the end of the 10-year hypothetical drought period, base flows at the Sweetwater (07301420), Carter (07301500), Headrick (07305000), and Snyder (07307010) streamgages had decreased by about 37, 61, 44, and 45 percent, respectively. The minimum Lake Altus storage simulated during the drought period was 403 acre-feet, which was a decline of 92 percent from the nondrought storage. Reduced base flows in the North Fork Red River were the primary cause of Lake Altus storage declines.

\section{References Cited}

Adams, G.P., and Bergman, D.L., 1996, Geohydrology of alluvium and terrace deposits of the Cimarron River from Freedom to Guthrie, Oklahoma: U.S. Geological Survey Water-Resources Investigations Report 95-4066, 57 p.

Alder, J.R., and Hostetler, S.W., 2013, CMIP5 Global Climate Change Viewer: U.S. Geological Survey, accessed June 30, 2017, at http://regclim.coas.oregonstate.edu/gccv/index. html.

Barclay, J.E., and Burton, L.C., 1953, Ground-water resources of the terrace deposits and alluvium of western Tillman County, Oklahoma: Oklahoma Planning and Resources Board, Division of Water Resources, Bulletin 12, 71 p.

Barlow, P.M., Cunningham, W.L., Zhai, Tong, and Gray, Mark, 2015, U.S. Geological Survey groundwater toolbox, a graphical and mapping interface for analysis of hydrologic data (version 1.0) - User guide for estimation of base flow, runoff, and groundwater recharge from streamflow data: U.S. Geological Survey Techniques and Methods 3-B10, 27 p., accessed June 30, 2017, at https://dx.doi.org/10.3133/ tm3B10.

Barlow, P.M., and Leake, S.A., 2012, Streamflow depletion by wells-Understanding and managing the effects of groundwater pumping on streamflow: U.S. Geological Survey Circular 1376, 84 p. (Also available at https://pubs. usgs.gov/circ/1376/.)
Belden, Mark, and Osborn, N.I., 2002, Hydrogeologic investigation of the Ogallala aquifer in Roger Mills and Beckham Counties, western Oklahoma: Oklahoma Water Resources Board Technical Report GW2002-2, accessed June 30, 2017, at http://www.owrb.ok.gov/studies/reports/ reports_pdf/GW2002_2_Ogallala_RogerMills_Beckham. pdf.

Burton, L.C., 1965, Ground water in terrace deposits of central Beckham County, Oklahoma: Oklahoma Water Resources Board Bulletin 25, 30 p.

Clark, B.R., and Hart, R.M., 2009, The Mississippi Embayment Regional Aquifer Study (MERAS) Documentation of a groundwater-flow model constructed to assess water availability in the Mississippi Embayment: U.S. Geological Survey Scientific Investigations Report 2009-5172, $61 \mathrm{p}$.

Cleveland, W., 1979, Robust locally weighted regression and smoothing scatterplots: Journal of the American Statistical Association, v. 74, p. 829-836.

Cooper, H.H., and Jacob, C.E., 1946, A generalized graphical method for evaluating formation constants and summarizing well field history: American Geophysical Union Transactions, v. 27, p. 526-534.

Cunningham, W.L., and Schalk, C.W., 2011, Groundwater technical procedures of the U.S. Geological Survey: U.S. Geological Survey Techniques and Methods 1-A1, 151 p.

Darcy, H., 1856, Les Fontances publiques de la ville de Dijon: Paris, Victor Dalmont.

Doherty, J., 2010, PEST, model independent parameter estimation-User manual (5th ed.): Brisbane, Australia, Watermark Numerical Computing, accessed September 24, 2015, at http://pesthomepage.org/.

Dripps, W.R., 2003, The spatial and temporal variability of groundwater recharge within the Trout Lake basin of northern Wisconsin: Madison, Wis., University of Wisconsin, Ph.D. dissertation, 231 p.

Ellis, J.H., Mashburn, S.L, Graves, G.M., Peterson, S.M., Smith, S.J., Fuhrig, L.F., Wagner, D.L., and Sanford, J.E, 2017, Hydrogeology and simulation of groundwater flow and analysis of projected water use for the Canadian River alluvial aquifer, western and Central Oklahoma: U.S. Geological Survey Scientific Investigations Report 20165180, $64 \mathrm{p}$.

Esralew, R.A., and Lewis, J.M., 2010, Trends in base flow, total flow, and base-flow index of selected streams in and near Oklahoma through 2008: U.S. Geological Survey Scientific Investigations Report 2010-5104, 143 p. 
Esri, Inc., 2017, How IDW works, ArcGIS for Desktop Help: Redlands, Calif., Esri, Inc., accessed March 24, 2017, at http://desktop.arcgis.com/en/arcmap/10.3/tools/3d-analysttoolbox/how-idw-works.htm.

Fry, J.A., Xian, George, Jin, Suming, Dewitz, J.A., Homer, C.G., Yang, Limin, Barnes, C.A., Herold, N.D., and Wickham, J.D., 2011, Completion of the 2006 National Land Cover Database for the conterminous United States: Photogrammetric Engineering and Remote Sensing, v. 77, no. 9, p. 858-864.

Geoprobe Systems, 2015, Geoprobe ${ }^{\circledR}$ Hydraulic Profiling Tool (HPT) system, standard operating procedure: Salina, Kan., Kejr, Inc., Technical Bulletin No. MK3137, 22 p., accessed March 14, 2017, at http://geoprobe.com/literature/hpt-sop.

Gouin, F., 1927, Geology of Beckham County: Oklahoma Geological Survey Bulletin 40-M, 17 p., 2 pls.

Gutentag, E.D., Heimes, F.J., Krothe, N.C., Luckey, R.R., and Weeks, J.B., 1984, Geohydrology of the High Plains aquifer in parts of Colorado, Kansas, Nebraska, New Mexico, Oklahoma, South Dakota, Texas, and Wyoming: U.S. Geological Survey Professional Paper 1400-B, 63 p.

Harbaugh, A.W., 1990, A computer program for calculating subregional water budgets using results from the U.S. Geological Survey modular three-dimensional groundwaterflow model: U.S. Geological Survey Open-File Report 90-392, 46 p.

Harbaugh, A.W., 2005, MODFLOW-2005, The U.S. Geological Survey modular ground-water model - the ground-water flow process: U.S. Geological Survey Techniques and Methods 6-A16 [variously paged].

Harbaugh, A.W., Banta, E.R., Hill, M.C., and McDonald, M.G., 2000, MODFLOW-2000, the U.S. Geological Survey modular groundwater model-User guide to modularization concepts and the groundwater flow process: U.S. Geological Survey Open-File Report 00-92, 121 p.

Hargreaves, G.H., and Samani, Z.A., 1985, Reference crop evapotranspiration from temperature: Applied Engineering in Agriculture, v. 1, no. 2, p. 96-99.

Healy, R.W., and Cook, P.G., 2002, Using groundwater levels to estimate recharge: Hydrogeology Journal, v. 10, p. 91-109.

Hill, M.C., and Tiedeman, C.R., 2007, Effective groundwater model calibration - With analysis of data, sensitivities, predictions, and uncertainty: New York, Wiley and Sons, $455 \mathrm{p}$.
Hollowell, J.R., 1965a, Ground water in the alluvium of Otter Creek basin, Oklahoma: Oklahoma Water Resources Board Bulletin 27, 15 p.

Hollowell, J.R., 1965b, Ground water in the alluvium of Elk Creek basin, Oklahoma: Oklahoma Water Resources Board Bulletin 28, 12 p.

Horizon Systems Corporation, 2015, National Hydrography Dataset Plus (NHDPlus): Horizon Systems Corporation, accessed November 1, 2010, at http://www.horizonsystems.com/nhdplus/.

Johnson, A.I., 1967, Sy-Compilation of Sys for various materials: U.S. Geological Survey Water-Supply Paper 1662-D, 74 p.

Johnson, K.S., ed., 1989, Anadarko Basin Symposium, 1988: Oklahoma Geological Survey Circular 90, 289 p., accessed June 30, 2017, at http://www.ogs.ou.edu/pubsscanned/ Circulars/Circular90.pdf.

Johnson, K.S., Stanley, T.M., and Miller, G.W., 2003, Geologic map of the Elk City 30' X 60' quadrangle, Beckham, Custer, Greer, Harmon, Kiowa, Roger Mills, and Washita Counties, Oklahoma: Oklahoma Geological Survey Geologic Quadrangle Map OGQ-44, scale 1:100,000, accessed December 4, 2015, at http://ogs.ou.edu/docs/OGQ/ OGQ-44.pdf.

Kennon, F.W., 1966, Hydrologic effects of small reservoirs in Sandstone Creek watershed, Beckham and Roger Mills Counties, western Oklahoma: U.S. Geological Survey Water-Supply Paper 1839-C, 39 p.

Kent, D.C., 1980, Evaluation of aquifer performance and water supply capabilities of alluvial and terrace deposits of the North Fork of the Red River in Beckham, Greer, Kiowa and Jackson Counties, Oklahoma: Final Report submitted to the Oklahoma Water Resources Board, 132 p., accessed June 30, 2017, at http://www.owrb.ok.gov/studies/reports/ reports_pdf/RedRiverNFork1980.pdf.

Kottek, M., Grieser, J., Beck, C., Rudolf, B., and Rubel, F., 2006, World map of the Köppen-Geiger climate classification updated: Meteorologische Zeitschrift, v. 15, p. 259-263. accessed June 30, 2017, at https://doi. org/10.1127/0941-2948/2006/0130.

Luza, K.V., 1989, Neotectonics and seismicity of the Anadarko Basin, in Johnson, K.S., ed., Anadarko Basin Symposium, 1988: Oklahoma Geological Survey Circular 90, p. 121132.

Mandelbrot, B.B., 1983, The fractal geometry of nature: New York, W.H. Freeman, 468 p. 
Mashburn, S.L., Ryter, D.W., Neel, C.R., Smith, S.J., and Magers, J.S., 2013, Hydrogeology and simulation of groundwater flow in the Central Oklahoma (GarberWellington) aquifer, Oklahoma, 1987 to 2009, and simulation of available water in storage, 2010-2059: U.S. Geological Survey Scientific Investigations Report 2013-5219, 92 p., accessed June 30, 2017, at http://dx.doi. org/10.3133/sir20135219.

Masoner, J.R., Mladinich, C.S., Konduris, A.M., and Smith, S.J., 2003, Comparison of irrigation water use estimates calculated from remotely sensed irrigated acres and state reported irrigated acres in the Lake Altus drainage basin, Oklahoma and Texas, 2000 growing season: U.S. Geological Survey Water-Resources Investigations Report 03-4155, 38 p.

McCall, Wes, 2010, Tech Guide for calculation of estimated hydraulic conductivity (Est. K) log from HPT data: Salina, Kan., Kejr, Inc., 20 p., accessed March 14, 2017, at http://geoprobe.com/literature/tech-guide-for-estimating-kusing-hpt.

Merritt, C.A., 1958, Igneous geology of the Lake Altus area, Oklahoma: Oklahoma Geological Survey Bulletin 76, 70 p.

Merritt, M.L., and Konikow, K.F., 2000, Documentation of a computer program to simulate lake-aquifer interaction using the MODFLOW ground-water flow model and the MOC3D solute-transport model: U.S. Geological Survey WaterResources Investigations Report 00-4167, 146 p.

Miller, G.W., and Stanley, T.M., 2004, Geologic map of the Anadarko 30' X 60' quadrangle, Caddo, Canadian, Custer, Grady, Kiowa and Washita Counties, Oklahoma: Oklahoma Geological Survey Geologic Quadrangle Map OGQ-58, scale 1:100,000, accessed December 4, 2015, at http://ogs. ou.edu/docs/OGQ/OGQ-58.pdf.

Multi-Resolution Land Characteristics Consortium, 2011, National Land Cover Database 2006 (NLCD 2006): U.S. Geological Survey, accessed October 3, 2011, at http:/ www.mrlc.gov/nlcd2006.php.

National Agricultural Statistics Service, 2015, Oklahoma agricultural statistics 2015, accessed November 25, 2015, at http://www.nass.usda.gov/Statistics_by_State/Oklahoma/ Publications/Annual_Statistical_Bulletin/ok_bulletin_2015. pdf.

National Agricultural Statistics Service, 2016, CropScape, cropland data layers, 2010-15, accessed June 30, 2017, at https://nassgeodata.gmu.edu/CropScape/.

National Climatic Data Center, 2015, Climate data online, accessed February 18, 2015, at https://www.ncdc.noaa.gov/ cdo-web/.
National Climatic Data Center, 2016, Climate data online, accessed July 20, 2016, at https://www7.ncdc.noaa.gov/ CDO/CDODivisionalSelect.jsp.

National Oceanic and Atmospheric Administration, 2015, Orthometric height conversion, accessed December 1, 2015, at https://alt.ngs.noaa.gov/cgi-bin/VERTCON/vert_con.prl.

Natural Resources Conservation Service, 2015, Geospatial Data Gateway, accessed March 14, 2013, at https:// datagateway.nrcs.usda.gov/.

Neuman, S.P., 1987, On methods of determining specific yield: Ground Water, v. 25, no. 6, p. 679.

Niswonger, R.G., Panday, Sorab, and Ibaraki, Motomu, 2011, MODFLOW-NWT, A Newton formulation for MODFLOW-2005: U.S. Geological Survey Techniques and Methods 6-A37, 44 p.

Niswonger, R.G., and Prudic, D.E., 2005, Documentation of the Streamflow-Routing (SFR2) Package to include unsaturated flow beneath streams-A modification to SFR1: U.S. Geological Survey Techniques and Methods 6-A13, $50 \mathrm{p}$.

Northcutt, R.A., and Campbell, J.A., 1995, Geologic provinces of Oklahoma: Oklahoma Geological Survey Open-File Report 5-95, scale 1:750,000.

Oklahoma Climatological Survey, 2015a, Daily time series using cooperative observer (COOP) data, accessed November 2015 at http://climate.ok.gov/cgi-bin/public/ climate.timeseries.one.cgi.

Oklahoma Climatological Survey, 2015b, Average length of growing season, accessed November 25, 2015, at http:// climate.ok.gov/index.php/climate/map/average_length_of_ growing_season/oklahoma_south-central_u.s.

Oklahoma Mesonet, 2015, Daily data retrieval, accessed November 25, 2015, at http://www.mesonet.org/index.php/ weather/daily_data_retrieval.

Oklahoma Water Resources Board [OWRB], 1998, Rural water systems in Oklahoma: Oklahoma Water Resources Board Publication 138, 212 p.

Oklahoma Water Resources Board [OWRB], 2010, Determination of maximum annual yield: Oklahoma Water Resources Board Fact Sheet, 2 p., accessed July 5, 2017, at https://www.owrb.ok.gov/util/pdf_util/Arbuckle\%20 MAY\%20Hearing/prehearing_docs/6-DeterminationMAY. pdf.

Oklahoma Water Resources Board [OWRB], 2012a, Oklahoma Comprehensive Water Plan Southwest Watershed Planning Region Report, 168 p. 
Oklahoma Water Resources Board [OWRB], 2012b, Oklahoma Comprehensive Water Plan Executive Report, 159 p. [Also available at http://www.owrb.ok.gov/supply/ ocwp/pdf_ocwp/WaterPlanUpdate/draftreports/OCWP Executive Rpt FINAL.pdf.]

Oklahoma Water Resources Board [OWRB], 2015a, Oklahoma groundwater resources-Groundwater basins with final maximum annual yield determination, accessed December 30, 2015, at https:/www.owrb.ok.gov/maps/ pdf_map/GW\%20Groundwater\%20Basins\%20with\%20 MAY.pdf.

Oklahoma Water Resources Board [OWRB], 2015b, Data \& maps - Groundwater, accessed November 2015 at http:// www.owrb.ok.gov/maps/pmg/owrbdata_GW.html.

Oklahoma Water Resources Board [OWRB], 2015c, 2015 Oklahoma groundwater report—Beneficial Use Monitoring Program: Oklahoma Water Resources Board, 170 p., accessed July 5, 2017, at http://www.owrb.ok.gov/quality/ monitoring/bump/pdf_bump/Reports/GMAPreport2015.pdf.

Osborn, N.I., 2002, Update of the hydrologic survey of the Tillman Terrace Groundwater Basin, southwestern Oklahoma: Oklahoma Water Resources Board Technical Report GW2002-1, accessed July 5, 2017, at https://www.owrb.ok.gov/studies/reports/reports_pdf/ tillman_update.pdf.

Paukstaitis, E.J., 1981, Computer simulation of the alluvial aquifer along the North Fork of the Red River in southwestern Oklahoma: Oklahoma State University Master's Thesis, $110 \mathrm{p}$.

Piper, A.M., 1944, A graphic procedure in the geochemical interpretation of water analyses: American Geophysical Union Transactions, v. 25, p. 914-923.

Prickett, T.A., 1965, Type curve solution to aquifer test under water table conditions: Groundwater, v. 3, no. 3, p. 5-14.

Rantz, S.E., and others, 1982, Measurement and computation of streamflow-Volume 1. Measurement of stage and discharge: U.S. Geological Survey Water-Supply Paper 2175, $284 \mathrm{p}$.

Rorabaugh, M.I., 1964, Estimating changes in bank storage and groundwater contribution to streamflow: International Association of Scientific Hydrology, publication 63, p. 432-441.

Rutledge, A.T., 1998, Computer programs for describing the recession of ground-water discharge and for estimating mean groundwater recharge and discharge from streamflow records-Update: U.S. Geological Survey Water-Resources Investigations Report 98-4148, 43 p.
Ryter, D.W., and Correll, J.S., 2016, Hydrogeological framework, numerical simulation of groundwater flow, and effects of projected water use and drought for the Beaver-North Canadian River alluvial aquifer, northwestern Oklahoma: U.S. Geological Survey Scientific Investigations Report 2015-5183, 63 p. [Also available at https://dx.doi. org/10.3133/sir20155183.]

Scholl, Martha, Christenson, Scott, Cozzarelli, Isabelle, Ferree, Dale, and Jaeschke, Jeanne, 2005, Recharge processes in an alluvial aquifer riparian zone, Norman Landfill, Norman, Oklahoma, 1998-2000: U.S. Geological Survey Scientific Investigations Report 2004-5238, 54 p., accessed July 5, 2017, at https://pubs.usgs.gov/ sir/2004/5238/.

Shivers, M.J., and Andrews, W.J., 2013, Hydrologic drought of water year 2011 compared to four major drought periods of the 20th century in Oklahoma: U.S. Geological Survey Scientific Investigations Report 2013-5018, 52 p., accessed July 5, 2017, at https://pubs.usgs.gov/sir/2013/5018/.

Smith, S.J., Ellis, J.H., Wagner, D.L., and Peterson, S.M., 2017, MODFLOW-NWT model used in simulation of groundwater flow and availability in the North Fork Red River aquifer, southwest Oklahoma, 1980-2013: U.S. Geological Survey data release, accessed September 30, 2017, at https://doi.org/10.5066/F7JQ0ZXH.

Smith, S.J., and Esralew, R.A., 2010, StreamStats in Oklahoma-Drainage-basin characteristics and peak-flow frequency statistics for ungaged streams: U.S. Geological Survey Scientific Investigations Report 2009-5255, 59 p. [Also available at https://pubs.usgs.gov/sir/2009/5255/.]

Smith, S.J., Schneider, M.L., Masoner, J.R., and Blazs, R.L., 2003, Surface-water quality assessment of the North Fork Red River Basin upstream from Lake Altus, Oklahoma, 2002: U.S. Geological Survey Open-File Report 03-362, 23 p. [Also available at https://pubs.er.usgs.gov/publication/ ofr03362.]

Smith, S.J., and Wahl, K.L., 2003, Changes in streamflow and summary of major-ion chemistry and loads in the North Fork Red River Basin upstream from Lake Altus, northwestern Texas and western Oklahoma, 1945-1999: U.S. Geological Survey Water-Resources Investigations Report 03-4086, 36 p. [Also available at https://pubs. er.usgs.gov/publication/wri034086.]

Stanley, T.M., and Miller, G.W., 2004, Geologic map of the Oklahoma part of the Altus 30’ X 60' quadrangle, Greer, Harmon, Jackson, and Tillman Counties, Oklahoma: Oklahoma Geological Survey Geologic Quadrangle Map OGQ-59, scale 1:100,000, accessed December 4, 2015, at http://ogs.ou.edu/docs/OGQ/OGQ-59.pdf. 
Stanley, T.M., and Miller, G.W., 2005, Geologic map of the Lawton 30' X 60' quadrangle, Caddo, Comanche, Cotton, Grady, Kiowa, Stephens, and Tillman Counties, Oklahoma: Oklahoma Geological Survey Geologic Quadrangle Map OGQ-63, scale 1:100,000, accessed December 4, 2015, at http://ogs.ou.edu/docs/OGQ/OGQ-63.pdf.

Steele, C.E., and Barclay, J.E., 1965, Ground-water resources of Harmon County and adjacent parts of Greer and Jackson Counties, Oklahoma: Oklahoma Water Resources Board Bulletin 29, 96 p.

Stephens, C.M., 2003, W.C. Austin Project, Oklahoma water availability assessment, final report to the U.S. Bureau of Reclamation: Oklahoma Water Resources Board.

Stiff, H.A., Jr., 1951, The interpretation of chemical water analysis by means of patterns: Journal of Petroleum Technology, v. 3, no. 10, p. 15-17.

Sullivan, Kim, 1998, Hydrologic report of the southwestern Oklahoma groundwater basin in Caddo, Kiowa, and Jackson Counties: Oklahoma Water Resources Board Technical Report 98-3.

Texas Bureau of Economic Geology, 1992, Geologic map of Texas: 3 sheets, scale 1:500,000.

Theis, C.V., 1935, The relation between the lowering of the piezometric surface and the rate and duration of discharge of a well using groundwater storage: American Geophysical Union Transactions, v. 16, p. 519-524.

Thornthwaite, C.W., and Mather, J.R., 1957, Instructions and tables for computing potential evapotranspiration and the water balance: Centerton, N.J., Laboratory of Climatology, Publications in Climatology, v. 10, no. 3, p. 185-311.

Tortorelli, R.L., 2008, Hydrologic drought of Water Year 2006 compared with four major drought periods of the 20th century in Oklahoma: U.S. Geological Survey Scientific Investigations Report 2008-5199, 46 p. [Also available at https://pubs.usgs.gov/sir/2008/5199/.]

Trescott, P.C., Pinder, G.F., and Larson, S.P., 1976, Finitedifference model for aquifer simulation in two dimensions with results of numerical experiments: U.S. Geological Survey Techniques of Water-Resources Investigations, book 7, chap. C1, $116 \mathrm{p}$.

U.S. Army Corps of Engineers, 2015a, CorpsMap, National Inventory of Dams, accessed December 9, 2015, at http:// nid.usace.army.mil/.

U.S. Army Corps of Engineers, 2015b, Reservoir release, storage, evaporation, and precipitation data for lakes, accessed December 9, 2015, at http://www.swt-wc.usace. army.mil/stations.htm.
U.S. Bureau of Reclamation, 2014, 2007 Hydrologic and sedimentation survey of Altus Reservoir, accessed September 30, 2014, at https://catalog.data.gov/ dataset/2007-hydrologic-and-sedimentation-survey-of-altusreservoir.

U.S. Bureau of Reclamation, 2015a, Mountain Park Project, accessed December 9, 2015, at http://www.usbr.gov/ projects/Project.jsp?proj_Name=Mountain+Park+Project.

U.S. Bureau of Reclamation, 2015b, Reservoir release, storage, evaporation, and precipitation data for Lake Altus, Oklahoma, accessed December 9, 2015, at https://www. usbr.gov/gp-bin/custom.pl?SWE221A\&altus.

U.S. Bureau of Reclamation, 2015c, Reservoir release, storage, evaporation, and precipitation data for Tom Steed Reservoir, Oklahoma, accessed December 9, 2015, at http://www.usbr.gov/gp-bin/custom.pl?SWE221A\&toms.

U.S. Census Bureau, 2000, TIGER/Line Shapefiles and TIGER/Line Files: U.S. Census Bureau, accessed December 15, 2014, at https://www.census.gov/geo/mapsdata/data/tiger-line.html.

U.S. Environmental Protection Agency, 2017, Drinking water regulations and contaminants: accessed March 24, 2017, at https://www.epa.gov/dwregdev/drinking-water-regulationsand-contaminants.

U.S. Fish and Wildlife Service, 2015, National Wetlands Inventory - Download seamless wetlands data by State, accessed January 5, 2016, at https://www.fws.gov/wetlands/ Data/State-Downloads.html.

U.S. Geological Survey [USGS], 2015a, U.S. Geological Survey surface water and groundwater data for Oklahoma: U.S. Geological Survey National Water Information System database, accessed November 2015 at https://waterdata. usgs.gov/ok/nwis/.

U.S. Geological Survey [USGS], 2015b, National Elevation Dataset: accessed January 2015 at http://ned.usgs.gov/index. html.

U.S. Geological Survey [USGS], 2015c, Documentation: U.S. Geological Survey Annual Water Data Report, accessed October 2015 at https://wdr.water.usgs.gov/current/ documentation.html.

Wahl, K.L., and Wahl, T.L., 1995, Determining the flow of Comal Springs at New Braunfels, Texas, in Proceedings of Texas Water '95, A Component Conference of the First International Conference on Water Resources Engineering, San Antonio, Texas, August 16-17, 1995: American Society of Civil Engineers, p. 77-86. 
Westenbroek, S.M., Kelson, V.A., Dripps, W.R., Hunt, R.J., and Bradbury, K.R., 2010, SWB-A modified Thornthwaite-Mather Soil-Water-Balance code for estimating groundwater recharge: U.S. Geological Survey Techniques and Methods 6-A31, 60 p. [Also available at https://pubs.usgs.gov/tm/tm6-a31/.]

White, W.N., 1932, A method of estimating ground-water supplies based on discharge by plants and evaporation from soil-Results of investigations in Escalante Valley, Utah: U.S. Geological Survey Water Supply Paper 659-A, p. 1-105, accessed July 5, 2017, at https://pubs.er.usgs.gov/ publication/wsp659A.
Whittemore, D.O., Butler, J.J., and Wilson, B.B., 2016, Assessing the major drivers of water-level declines: New insights into the future of heavily stressed aquifers: Hydrological Sciences Journal, v. 61, no. 1, p. 134-145, accessed July 5, 2017, at http://dx.doi.org/10.1080/0262666 7.2014.959958. 
Table 1. Selected data-collection stations in and near the North Fork Red River aquifer study area, southwest Oklahoma.

[NAVD 88, North American Vertical Datum of 1988; >, greater than; SFR, Streamflow-Routing package; LAK, Lake package; WTF, water-table fluctuation method; SWB, Soil-Water Balance; m/d/y, month/day/year; --, not applicable or unknown]

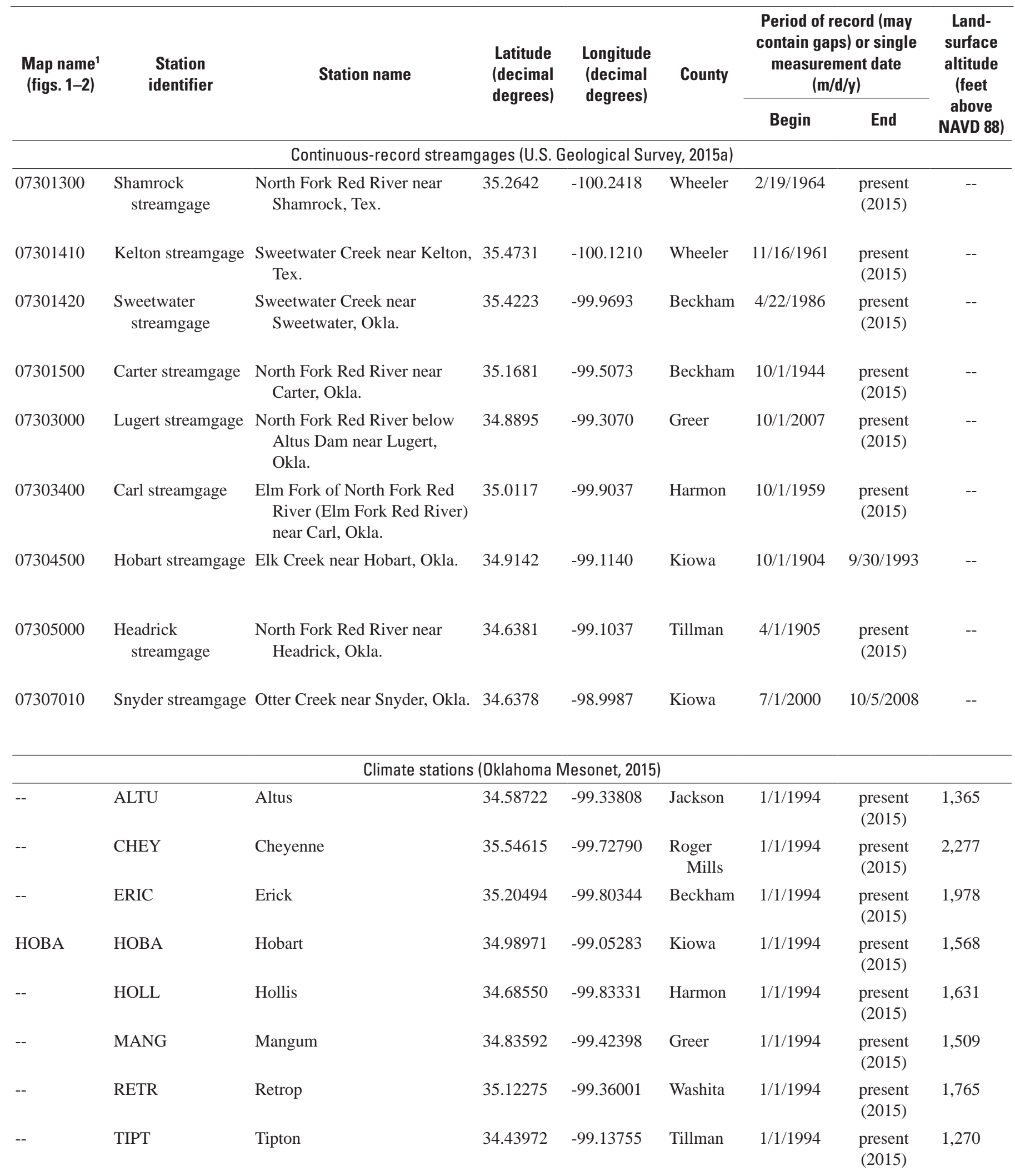




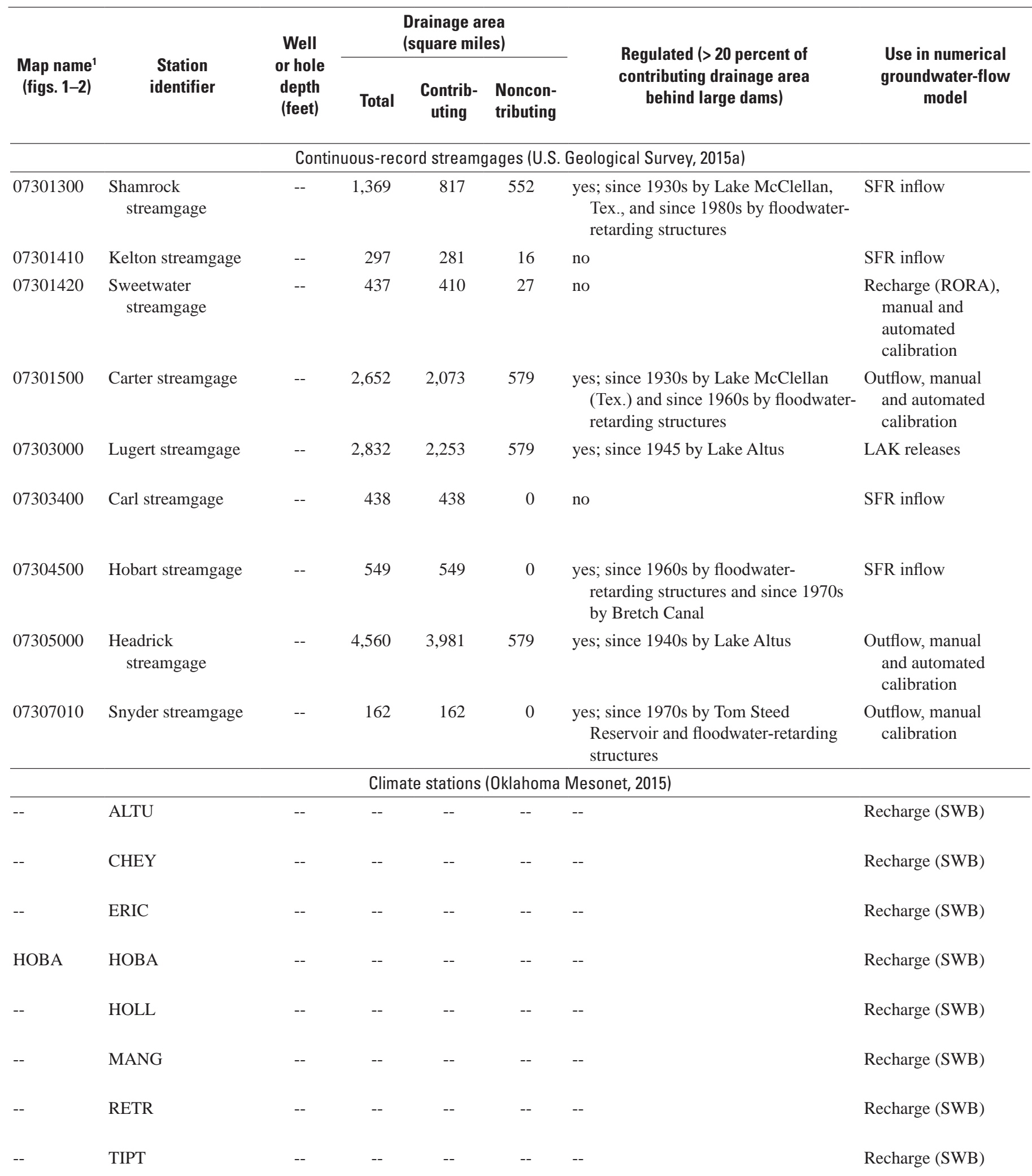


Table 1. Selected data-collection stations in and near the North Fork Red River aquifer study area, southwest Oklahoma.-Continued [NAVD 88, North American Vertical Datum of 1988; >, greater than; SFR, Streamflow-Routing package; LAK, Lake package; WTF, water-table fluctuation method; SWB, Soil-Water Balance; m/d/y, month/day/year; --, not applicable or unknown]

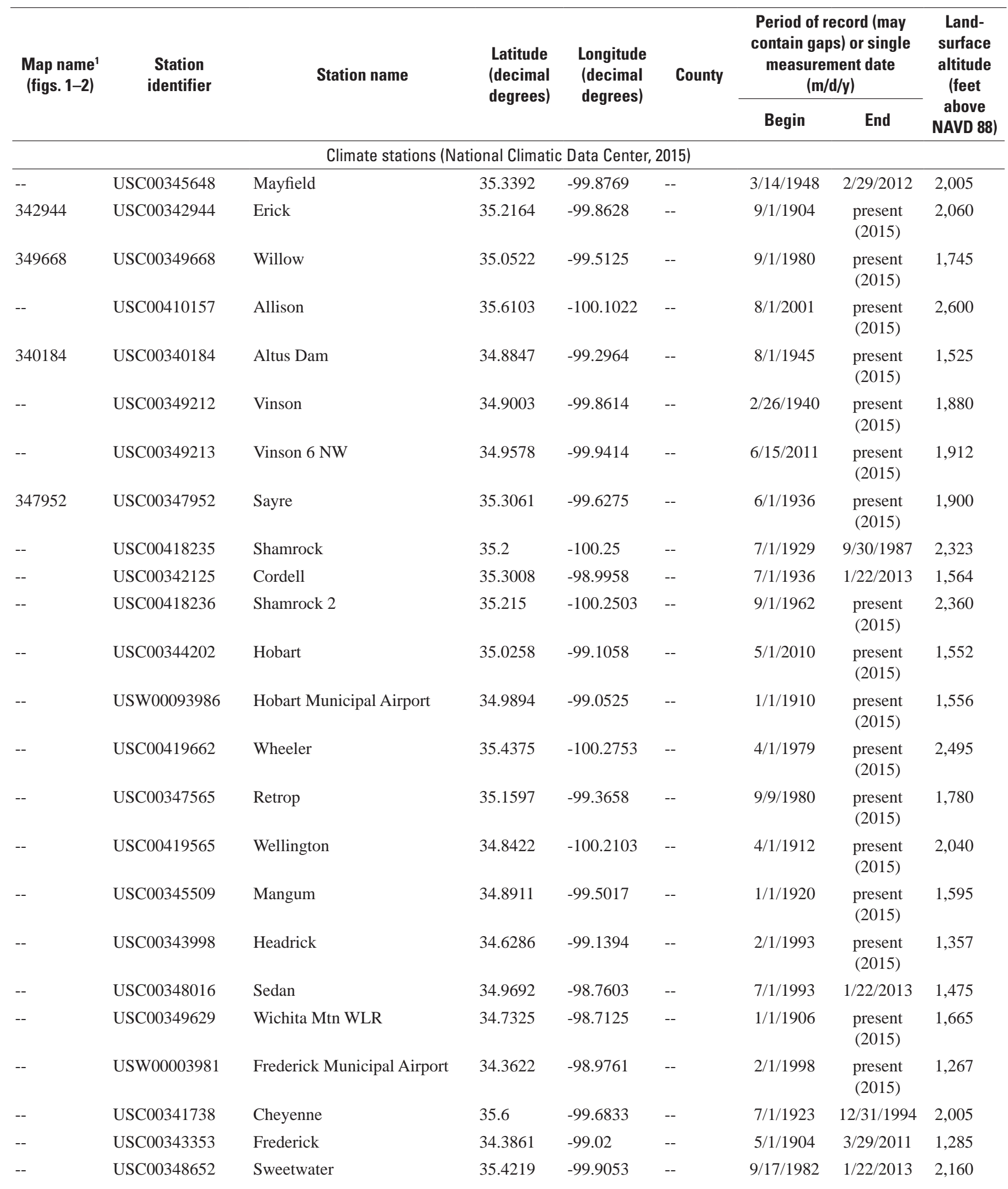




\begin{tabular}{|c|c|c|c|c|c|c|c|}
\hline \multirow{2}{*}{$\begin{array}{l}\text { Map name' } \\
\text { (figs. 1-2) }\end{array}$} & \multirow{2}{*}{$\begin{array}{l}\text { Station } \\
\text { identifier }\end{array}$} & \multirow{2}{*}{$\begin{array}{c}\text { Well } \\
\text { or hole } \\
\text { depth } \\
\text { (feet) }\end{array}$} & \multicolumn{3}{|c|}{$\begin{array}{l}\text { Drainage area } \\
\text { (square miles) }\end{array}$} & \multirow{2}{*}{$\begin{array}{l}\text { Regulated ( }>20 \text { percent of } \\
\text { contributing drainage area } \\
\text { behind large dams) }\end{array}$} & \multirow{2}{*}{$\begin{array}{c}\text { Use in numerical } \\
\text { groundwater-flow } \\
\text { model }\end{array}$} \\
\hline & & & Total & $\begin{array}{l}\text { Contrib- } \\
\text { uting }\end{array}$ & $\begin{array}{l}\text { Noncon- } \\
\text { tributing }\end{array}$ & & \\
\hline \multicolumn{8}{|c|}{ Climate stations (National Climatic Data Center, 2015) } \\
\hline-- & USC00345648 & -- & -- & -- & -- & -- & Recharge (SWB) \\
\hline 342944 & USC00342944 & -- & -- & -- & -- & -- & Recharge (SWB) \\
\hline 349668 & USC00349668 & -- & -- & -- & -- & -- & Recharge (SWB) \\
\hline-- & USC00410157 & -- & -- & -- & -- & -- & Recharge (SWB) \\
\hline 340184 & USC00340184 & -- & -- & -- & -- & -- & Recharge (SWB) \\
\hline-- & USC00349212 & -- & -- & -- & -- & -- & Recharge (SWB) \\
\hline-- & USC00349213 & -- & -- & -- & -- & -- & Recharge (SWB) \\
\hline 347952 & USC00347952 & -- & -- & -- & -- & -- & Recharge (SWB) \\
\hline-- & USC00418235 & -- & -- & -- & -- & -- & Recharge (SWB) \\
\hline-- & USC00342125 & -- & -- & -- & -- & -- & Recharge (SWB) \\
\hline-- & USC00418236 & -- & -- & -- & -- & -- & Recharge (SWB) \\
\hline-- & USC00344202 & -- & -- & -- & -- & -- & Recharge (SWB) \\
\hline-- & USW00093986 & -- & -- & -- & -- & -- & Recharge (SWB) \\
\hline-- & USC00419662 & -- & -- & -- & -- & -- & Recharge (SWB) \\
\hline-- & USC00347565 & -- & -- & -- & -- & -- & Recharge (SWB) \\
\hline-- & USC00419565 & -- & -- & -- & -- & -- & Recharge (SWB) \\
\hline-- & USC00345509 & -- & -- & -- & -- & -- & Recharge (SWB) \\
\hline-- & USC00343998 & -- & -- & -- & -- & -- & Recharge (SWB) \\
\hline-- & USC00348016 & -- & -- & -- & -- & -- & Recharge (SWB) \\
\hline-- & USC00349629 & -- & -- & -- & -- & -- & Recharge (SWB) \\
\hline-- & USW00003981 & -- & -- & -- & -- & -- & Recharge (SWB) \\
\hline-- & USC00341738 & -- & -- & -- & -- & -- & Recharge (SWB) \\
\hline -- & USC00343353 & -- & -- & -- & -- & -- & Recharge (SWB) \\
\hline-- & USC00348652 & -- & -- & -- & -- & -- & Recharge (SWB) \\
\hline
\end{tabular}


Table 1. Selected data-collection stations in and near the North Fork Red River aquifer study area, southwest Oklahoma.-Continued [NAVD 88, North American Vertical Datum of 1988; >, greater than; SFR, Streamflow-Routing package; LAK, Lake package; WTF, water-table fluctuation method; SWB, Soil-Water Balance; m/d/y, month/day/year; --, not applicable or unknown]

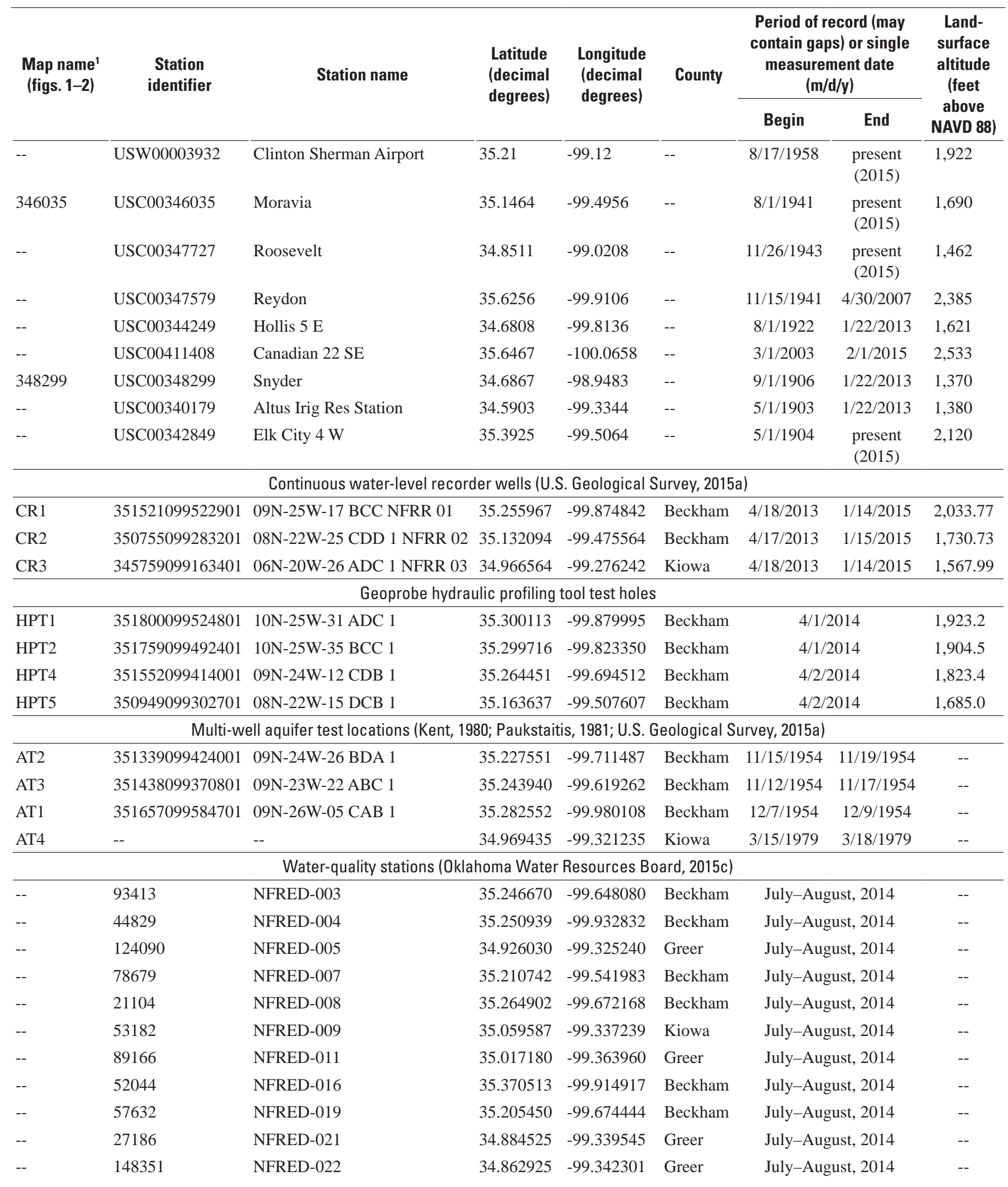




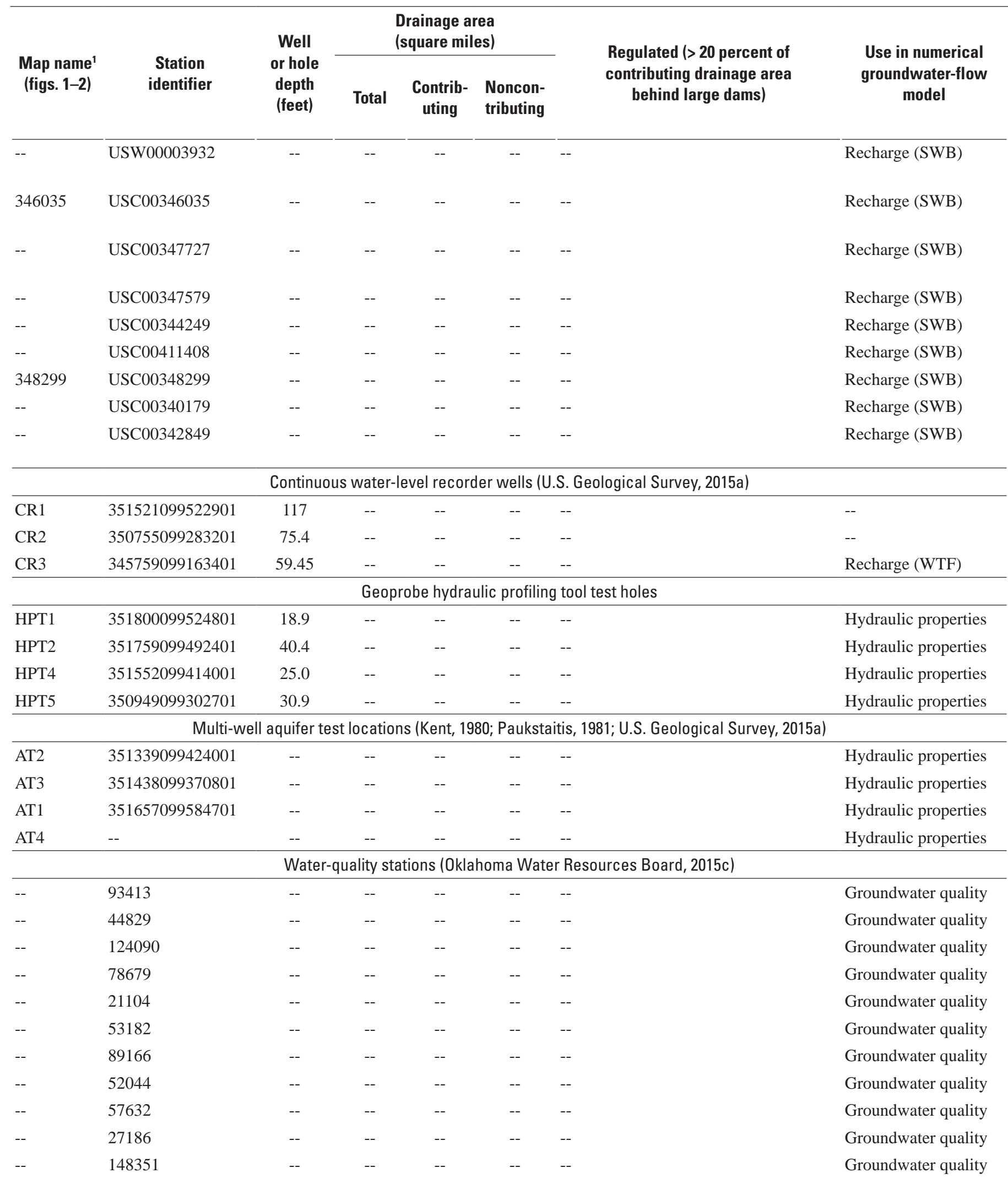


Table 1. Selected data-collection stations in and near the North Fork Red River aquifer study area, southwest Oklahoma.-Continued [NAVD 88, North American Vertical Datum of 1988; >, greater than; SFR, Streamflow-Routing package; LAK, Lake package; WTF, water-table fluctuation method; SWB, Soil-Water Balance; m/d/y, month/day/year; --, not applicable or unknown]

\begin{tabular}{|c|c|c|c|c|c|c|c|c|}
\hline \multirow[t]{2}{*}{$\begin{array}{c}\text { Map name } \\
\text { (figs. 1-2) }\end{array}$} & \multirow[t]{2}{*}{$\begin{array}{l}\text { Station } \\
\text { identifier }\end{array}$} & \multirow[t]{2}{*}{ Station name } & \multirow[t]{2}{*}{$\begin{array}{l}\text { Latitude } \\
\text { (decimal } \\
\text { degrees) }\end{array}$} & \multirow[t]{2}{*}{$\begin{array}{l}\text { Longitude } \\
\text { (decimal } \\
\text { degrees) }\end{array}$} & \multirow[t]{2}{*}{ County } & \multicolumn{2}{|c|}{$\begin{array}{l}\text { Period of record (may } \\
\text { contain gaps) or single } \\
\text { measurement date } \\
(\mathrm{m} / \mathrm{d} / \mathrm{y})\end{array}$} & \multirow{2}{*}{$\begin{array}{c}\text { Land- } \\
\text { surface } \\
\text { altitude } \\
\text { (feet } \\
\text { above } \\
\text { NAVD 88) }\end{array}$} \\
\hline & & & & & & Begin & End & \\
\hline- & 27136 & NFRED-023 & 35.266728 & -99.634720 & $\overline{\text { Beckham }}$ & \multicolumn{2}{|c|}{ July-August, 2014} & -- \\
\hline-- & 44825 & NFRED-024 & 35.267222 & -99.796015 & Beckham & \multicolumn{2}{|c|}{ July-August, 2014} & -- \\
\hline-- & 21131 & NFRED-036 & 35.246866 & -99.679087 & Beckham & \multicolumn{2}{|c|}{ July-August, 2014} & -- \\
\hline-- & 80060 & NFRED-044 & 35.339491 & -99.778398 & Beckham & \multicolumn{2}{|c|}{ July-August, 2014} & -- \\
\hline-- & 118864 & NFRED-052 & 35.205117 & -99.725950 & Beckham & \multicolumn{2}{|c|}{ July-August, 2014} & -- \\
\hline-- & 21327 & NFRED-070 & 35.298109 & -99.857739 & Beckham & \multicolumn{2}{|c|}{ July-August, 2014} & -- \\
\hline -- & 21540 & NFRED-073 & 34.893647 & -99.335095 & Greer & \multicolumn{2}{|c|}{ July-August, 2014} & -- \\
\hline-- & 80000 & NFRED-078 & 35.299360 & -99.823090 & Beckham & \multicolumn{2}{|c|}{ July-August, 2014} & -- \\
\hline-- & 118145 & NFRED-098 & 35.288040 & -99.704080 & Beckham & \multicolumn{2}{|c|}{ July-August, 2014} & -- \\
\hline \multicolumn{9}{|c|}{ Water-quality stations (U.S. Geological Survey, 2015a) } \\
\hline- & 343755099061001 & 02N-18W-21 BD 1 & 34.632016 & -99.103135 & Jackson & \multicolumn{2}{|c|}{ 9/1/1947 } & -- \\
\hline-- & 343920098584001 & $02 \mathrm{~N}-17 \mathrm{~W}-10 \mathrm{C} 1$ & 34.655626 & -98.978132 & Kiowa & \multicolumn{2}{|c|}{ 8/15/1958 } & -- \\
\hline-- & 344037099032901 & 02N-18W-02 A 1 & 34.677014 & -99.058412 & Kiowa & \multicolumn{2}{|c|}{ 8/8/1959 } & -- \\
\hline-- & 344037099032902 & 02N-18W-02 A 2 & 34.677014 & -99.058412 & Kiowa & \multicolumn{2}{|c|}{ 8/8/1959 } & -- \\
\hline-- & 344100098581001 & 03N-17W-34 CCD 1 & 34.683402 & -98.969798 & Kiowa & \multicolumn{2}{|c|}{ 2/15/1961 } & -- \\
\hline-- & 345400099166501 & $05 N-20 W-24$ B 1 & 34.900060 & -99.268416 & Kiowa & \multicolumn{2}{|c|}{ 8/4/1959 } & -- \\
\hline-- & 345450099282501 & 05N-22W-13 AAA 1 & 34.913948 & -99.473977 & Greer & \multicolumn{2}{|c|}{$12 / 23 / 1953$} & -- \\
\hline-- & 345820099164501 & $06 \mathrm{~N}-20 \mathrm{~W}-26$ A 1 & 34.972280 & -99.279526 & Kiowa & \multicolumn{2}{|c|}{ 4/25/1961 } & -- \\
\hline-- & 351218099394501 & 09N-23W-32 CCC 1 & 35.205052 & -99.662874 & Beckham & $2 / 26 /$ & 1952 & -- \\
\hline-- & 351301099485301 & 09N-25W-35 BAA 4 & 35.216996 & -99.815102 & Beckham & $2 / 26 /$ & 1952 & -- \\
\hline-- & 351312099513501 & 09N-25W-29 DDD 1 & 35.220052 & -99.860103 & Beckham & $2 / 27 /$ & 1952 & -- \\
\hline-- & 351336099341901 & 09N-22W-30 CBA 1 & 35.226718 & -99.572316 & Beckham & $11 / 1 /$ & 1951 & -- \\
\hline-- & 351336099342401 & 09N-22W-30 BCD 1 & 35.226718 & -99.573705 & Beckham & $11 / 1 /$ & 1951 & -- \\
\hline-- & 351339099424001 & 09N-24W-26 BDA 1 & 35.227551 & -99.711487 & Beckham & $11 / 15$ & 1954 & -- \\
\hline-- & 351439099364001 & 09N-23W-23 BBC 1 & 35.244218 & -99.611484 & Beckham & $11 / 1 /$ & 1951 & -- \\
\hline-- & 351447099542001 & 09N-26W-19 AAA 1 & 35.246441 & -99.905939 & Beckham & $3 / 5 / 1$ & 952 & -- \\
\hline-- & 351520099404001 & 09N-23W-07 CB 1 & 35.255607 & -99.678153 & Beckham & $11 / 28$ & 1962 & -- \\
\hline-- & 351555099431401 & 09N-24W-10 DDD 1 & 35.265329 & -99.720933 & Beckham & 2/14/ & 1952 & -- \\
\hline-- & 351614099383602 & 09N-23W-09 BCD 2 & 35.270607 & -99.643708 & Beckham & $11 / 2 /$ & 1951 & -- \\
\hline-- & 351657099584701 & 09N-26W-05 CAB 1 & 35.282552 & -99.980108 & Beckham & $12 / 7 /$ & 1954 & -- \\
\hline-- & 351800099510001 & 10N-25W-35 CBB 1 & 35.300051 & -99.850382 & Beckham & $3 / 2 /$ & 952 & -- \\
\hline & Water-table-altitude & $\begin{array}{l}\text { observation and Mass } \\
\text { Land-surface el }\end{array}$ & $\begin{array}{l}\text { ent Progra } \\
\text { om U.S. Ge }\end{array}$ & $\begin{array}{l}\text { n wells (Oklah } \\
\text { ological Surve }\end{array}$ & $\begin{array}{l}\text { oma Water } \\
\text { y (2015b) }\end{array}$ & esources Bo & ard, 2015b); & \\
\hline 9088 & 350727099274901 & 08N-21W-31 CBB 1 & 35.123125 & -99.464492 & Beckham & $3 / 5 / 1980$ & $\begin{array}{l}\text { present } \\
(2015)\end{array}$ & $1,734.8$ \\
\hline 9089 & 350839099303001 & 08N-22W-27 AAD 1 & 35.142600 & -99.501253 & Beckham & 3/5/1980 & $\begin{array}{l}\text { present } \\
(2015)\end{array}$ & $1,706.7$ \\
\hline 9090 & 351030099385401 & 08N-23W-17 AAB 1 & 35.174764 & -99.649906 & Beckham & 3/6/1980 & $\begin{array}{l}\text { present } \\
\text { (2015) }\end{array}$ & $1,906.0$ \\
\hline 9092 & 351122099435501 & 08N-24W-09 AAB 1 & 35.189406 & -99.734072 & Beckham & 3/6/1980 & $1 / 20 / 2000$ & $1,954.1$ \\
\hline
\end{tabular}




\begin{tabular}{|c|c|c|c|c|c|c|c|}
\hline \multirow{2}{*}{$\begin{array}{l}\text { Map name' }^{1} \\
\text { (figs. 1-2) }\end{array}$} & \multirow{2}{*}{$\begin{array}{l}\text { Station } \\
\text { identifier }\end{array}$} & \multirow{2}{*}{$\begin{array}{c}\text { Well } \\
\text { or hole } \\
\text { depth } \\
\text { (feet) }\end{array}$} & \multicolumn{3}{|c|}{$\begin{array}{l}\text { Drainage area } \\
\text { (square miles) }\end{array}$} & \multirow{2}{*}{$\begin{array}{l}\text { Regulated ( }>20 \text { percent of } \\
\text { contributing drainage area } \\
\text { behind large dams) }\end{array}$} & \multirow{2}{*}{$\begin{array}{c}\text { Use in numerical } \\
\text { groundwater-flow } \\
\text { model }\end{array}$} \\
\hline & & & Total & $\begin{array}{l}\text { Contrib- } \\
\text { uting }\end{array}$ & $\begin{array}{l}\text { Noncon- } \\
\text { tributing }\end{array}$ & & \\
\hline-- & 27136 & -- & -- & -- & -- & -- & Groundwater quality \\
\hline-- & 44825 & -- & -- & -- & -- & -- & Groundwater quality \\
\hline-- & 21131 & -- & -- & -- & -- & -- & Groundwater quality \\
\hline-- & 80060 & -- & -- & -- & -- & -- & Groundwater quality \\
\hline-- & 118864 & -- & -- & -- & -- & -- & Groundwater quality \\
\hline-- & 21327 & -- & -- & -- & -- & -- & Groundwater quality \\
\hline -- & 21540 & -- & -- & -- & -- & -- & Groundwater quality \\
\hline-- & 80000 & -- & -- & -- & -- & -- & Groundwater quality \\
\hline-- & 118145 & -- & -- & -- & -- & -- & Groundwater quality \\
\hline \multicolumn{8}{|c|}{ Water-quality stations (U.S. Geological Survey, 2015a) } \\
\hline-- & 343755099061001 & 9 & -- & -- & -- & -- & Groundwater quality \\
\hline-- & 343920098584001 & 50 & -- & -- & -- & -- & Groundwater quality \\
\hline-- & 344037099032901 & -- & -- & -- & -- & -- & Groundwater quality \\
\hline-- & 344037099032902 & -- & -- & -- & -- & -- & Groundwater quality \\
\hline-- & 344100098581001 & 53 & -- & -- & -- & -- & Groundwater quality \\
\hline-- & 345400099166501 & 70 & -- & -- & -- & -- & Groundwater quality \\
\hline-- & 345450099282501 & 35 & -- & -- & -- & -- & Groundwater quality \\
\hline-- & 345820099164501 & 15 & -- & -- & -- & -- & Groundwater quality \\
\hline -- & 351218099394501 & 63 & -- & -- & -- & -- & Groundwater quality \\
\hline-- & 351301099485301 & 22 & -- & -- & -- & -- & Groundwater quality \\
\hline-- & 351312099513501 & 49 & -- & -- & -- & -- & Groundwater quality \\
\hline-- & 351336099341901 & 58 & -- & -- & -- & -- & Groundwater quality \\
\hline-- & 351336099342401 & 60.3 & -- & -- & -- & -- & Groundwater quality \\
\hline -- & 351339099424001 & 188 & -- & -- & -- & -- & Groundwater quality \\
\hline-- & 351439099364001 & 95 & -- & -- & -- & -- & Groundwater quality \\
\hline-- & 351447099542001 & 68 & -- & -- & -- & -- & Groundwater quality \\
\hline-- & 351520099404001 & 36 & -- & -- & -- & -- & Groundwater quality \\
\hline-- & 351555099431401 & 27 & -- & -- & -- & -- & Groundwater quality \\
\hline-- & 351614099383602 & 60 & -- & -- & -- & -- & Groundwater quality \\
\hline-- & 351657099584701 & 102 & -- & -- & -- & -- & Groundwater quality \\
\hline -- & 351800099510001 & -- & -- & -- & -- & -- & Groundwater quality \\
\hline \multicolumn{8}{|c|}{$\begin{array}{l}\text { Water-table-altitude observation and Mass Measurement Program wells (Oklahoma Water Resources Board, 2015b); } \\
\text { Land-surface elevations from U.S. Geological Survey (2015b) }\end{array}$} \\
\hline 9088 & 350727099274901 & 76 & -- & -- & -- & -- & Calibration \\
\hline 9089 & 350839099303001 & 50 & -- & -- & -- & -- & Calibration \\
\hline 9090 & 351030099385401 & 80 & -- & -- & -- & -- & Calibration \\
\hline 9092 & 351122099435501 & 142 & -- & -- & -- & -- & Calibration \\
\hline
\end{tabular}


Table 1. Selected data-collection stations in and near the North Fork Red River aquifer study area, southwest Oklahoma.-Continued [NAVD 88, North American Vertical Datum of 1988; >, greater than; SFR, Streamflow-Routing package; LAK, Lake package; WTF, water-table fluctuation method; SWB, Soil-Water Balance; m/d/y, month/day/year; --, not applicable or unknown]

\begin{tabular}{|c|c|c|c|c|c|c|c|c|}
\hline \multirow[t]{2}{*}{$\begin{array}{c}\text { Map name' } \\
\text { (figs. 1-2) }\end{array}$} & \multirow[t]{2}{*}{$\begin{array}{l}\text { Station } \\
\text { identifier }\end{array}$} & \multirow[t]{2}{*}{ Station name } & \multirow[t]{2}{*}{$\begin{array}{l}\text { Latitude } \\
\text { (decimal } \\
\text { degrees) }\end{array}$} & \multirow[t]{2}{*}{$\begin{array}{l}\text { Longitude } \\
\text { (decimal } \\
\text { degrees) }\end{array}$} & \multirow[t]{2}{*}{ County } & \multicolumn{2}{|c|}{$\begin{array}{c}\text { Period of record (may } \\
\text { contain gaps) or single } \\
\text { measurement date } \\
(\mathrm{m} / \mathrm{d} / \mathrm{y})\end{array}$} & \multirow{2}{*}{$\begin{array}{l}\text { Land- } \\
\text { surface } \\
\text { altitude } \\
\text { (feet } \\
\text { above } \\
\text { NAVD 88) }\end{array}$} \\
\hline & & & & & & Begin & End & \\
\hline 9093 & 351129099415601 & 08N-24W-02 DCD 1 & 35.190528 & -99.699808 & Beckham & $1 / 21 / 1986$ & $2 / 6 / 1990$ & $1,921.3$ \\
\hline 9094 & 351215099292401 & 08N-22W-02 ABB 1 & 35.203983 & -99.492533 & Beckham & 3/19/1981 & $\begin{array}{l}\text { present } \\
(2015)\end{array}$ & $1,852.6$ \\
\hline 9095 & 351216099483501 & 09N-25W-35 DDD 1 & 35.207297 & -99.806075 & Beckham & 3/6/1980 & 2/8/2000 & $1,991.4$ \\
\hline 9096 & 351222099395801 & 09N-23W-32 CCB 1 & 35.207914 & -99.661567 & Beckham & 3/5/1980 & $\begin{array}{l}\text { present } \\
(2015)\end{array}$ & $1,882.7$ \\
\hline 9097 & 351242099420601 & 09N-24W-36 BCC 1 & 35.212608 & -99.698836 & Beckham & 3/7/1980 & 2/6/1990 & $1,918.5$ \\
\hline 9098 & 351301099323301 & 09N-22W-33 BBB 1 & 35.217650 & -99.540775 & Beckham & 3/5/1980 & $\begin{array}{l}\text { present } \\
\text { (2015) }\end{array}$ & $1,781.2$ \\
\hline 9099 & 351306099515501 & 09N-26W-33 BBB 1 & 35.218147 & -99.963903 & Beckham & 3/6/1980 & 2/21/1996 & $2,089.1$ \\
\hline 9100 & 351308099353601 & 09N-23W-25 CCD 1 & 35.219678 & -99.591186 & Beckham & 3/17/1981 & $\begin{array}{l}\text { present } \\
(2015)\end{array}$ & $1,853.0$ \\
\hline 9101 & 351327099595901 & 09N-26W-30 CBA 1 & 35.225547 & -99.995850 & Beckham & 3/6/1980 & $\begin{array}{l}\text { present } \\
(2015)\end{array}$ & $2,146.7$ \\
\hline 9102 & 351334099344001 & 09N-22W-30 BCC 1 & 35.226989 & -99.575067 & Beckham & 3/5/1980 & 1/27/1998 & $1,786.7$ \\
\hline 9103 & 351347099324101 & 09N-22W-29 AAD 1 & 35.230336 & -99.542769 & Beckham & 3/5/1980 & 2/22/1996 & $1,765.1$ \\
\hline 9104 & 351353099383101 & 09N-23W-28 BAA 1 & 35.232681 & -99.639411 & Beckham & 3/5/1980 & 2/13/1991 & $1,890.4$ \\
\hline 9105 & 351353099482701 & 09N-25W-25 BBB 1 & 35.233372 & -99.805669 & Beckham & 3/6/1980 & 3/9/1999 & $2,008.3$ \\
\hline 9106 & 351400099533501 & 09N-25W-31 ВСВ 1 & 35.214633 & -99.893617 & Beckham & 3/6/1980 & 1/28/2013 & $2,031.2$ \\
\hline 9107 & 351402099533501 & 09N-25W-19 CCC 1 & 35.234356 & -99.894219 & Beckham & 3/6/1980 & 3/19/2001 & $1,995.0$ \\
\hline 9108 & 351413099451601 & 09N-24W-21 CBC 2 & 35.237525 & -99.752531 & Beckham & 3/7/1980 & 2/23/2014 & $1,930.7$ \\
\hline 9109 & 351426099372701 & 09N-23W-22 BDD 1 & 35.246361 & -99.621225 & Beckham & 3/5/1980 & 1/30/2013 & $1,860.2$ \\
\hline 9110 & 351433099544101 & 09N-26W-24 BCA 1 & 35.242552 & -99.911772 & Beckham & 3/6/1980 & 2/21/1996 & $2,041.2$ \\
\hline 9111 & 351446099362401 & 09N-23W-23 BAA 2 & 35.246162 & -99.607039 & Beckham & 3/5/1980 & 2/22/1996 & $1,840.6$ \\
\hline 9112 & 351452099494701 & 09N-25W-15 DDC 1 & 35.249042 & -99.826822 & Beckham & 3/6/1980 & 3/14/1994 & $2,006.5$ \\
\hline 9113 & 351512099411001 & 09N-24W-13 DAA 1 & 35.254786 & -99.683769 & Beckham & 3/19/1981 & 3/17/2010 & $1,859.0$ \\
\hline 9114 & 351512099472401 & 09N-24W-18 CBB 1 & 35.255353 & -99.788100 & Beckham & 3/6/1980 & 2/24/2012 & $1,937.5$ \\
\hline 9115 & 351518099375901 & 09N-23W-16 ADD 1 & 35.255078 & -99.629367 & Beckham & 3/19/1981 & $1 / 20 / 2000$ & $1,863.1$ \\
\hline 9116 & 351525099560801 & 09N-26W-15 ADB 2 & 35.258089 & -99.932758 & Beckham & 3/6/1980 & 3/9/1999 & $1,999.2$ \\
\hline 9117 & 351557099522601 & 09N-25W-08 CAC 1 & 35.265885 & -99.874271 & Beckham & 3/6/1980 & 2/21/1996 & $2,000.9$ \\
\hline 9118 & 351617099482701 & 09N-25W-12 ВСВ 1 & 35.271667 & -99.803819 & Beckham & 3/6/1980 & $1 / 1 / 2007$ & $1,971.4$ \\
\hline 9119 & 351617099590301 & 09N-26W-08 ВСВ 1 & 35.271756 & -99.981142 & Beckham & 3/6/1980 & 3/17/2010 & $2,065.4$ \\
\hline 9120 & 351637099521001 & 09N-25W-05 DCC 1 & 35.277417 & -99.868419 & Beckham & 3/6/1980 & 3/7/2007 & $1,986.8$ \\
\hline 9121 & 351755099563201 & 10N-26W-34 BDD 1 & 35.298663 & -99.942607 & Beckham & 3/6/1980 & 3/10/1999 & $2,032.1$ \\
\hline 9122 & 352328099560001 & $11 \mathrm{~N}-26 \mathrm{~W}-34$ AAA 1 & 35.393153 & -99.929408 & Beckham & 3/6/1980 & $\begin{array}{l}\text { present } \\
(2015)\end{array}$ & $2,100.9$ \\
\hline 9123 & 352426099572801 & $11 \mathrm{~N}-26 \mathrm{~W}-21$ DCC 1 & 35.408200 & -99.955608 & Beckham & 3/6/1980 & $\begin{array}{l}\text { present } \\
\text { (2015) }\end{array}$ & $2,104.2$ \\
\hline 9438 & 345356099212801 & 05N-20W-19 BBB 1 & 34.899881 & -99.356489 & Greer & 2/27/1980 & 2/11/2014 & $1,525.9$ \\
\hline 9439 & 345356099224001 & 05N-21W-23 AAA 1 & 34.899736 & -99.379369 & Greer & 2/27/1980 & 2/20/2001 & $1,532.7$ \\
\hline
\end{tabular}




\begin{tabular}{|c|c|c|c|c|c|c|c|}
\hline \multirow{2}{*}{$\begin{array}{c}\text { Map name' } \\
\text { (figs. 1-2) }\end{array}$} & \multirow{2}{*}{$\begin{array}{l}\text { Station } \\
\text { identifier }\end{array}$} & \multirow{2}{*}{$\begin{array}{c}\text { Well } \\
\text { or hole } \\
\text { depth } \\
\text { (feet) }\end{array}$} & \multicolumn{3}{|c|}{$\begin{array}{l}\text { Drainage area } \\
\text { (square miles) }\end{array}$} & \multirow{2}{*}{$\begin{array}{c}\text { Regulated ( }>20 \text { percent of } \\
\text { contributing drainage area } \\
\text { behind large dams) }\end{array}$} & \multirow{2}{*}{$\begin{array}{c}\text { Use in numerical } \\
\text { groundwater-flow } \\
\text { model }\end{array}$} \\
\hline & & & Total & $\begin{array}{c}\text { Contrib- } \\
\text { uting }\end{array}$ & $\begin{array}{l}\text { Noncon- } \\
\text { tributing }\end{array}$ & & \\
\hline 9093 & 351129099415601 & -- & -- & -- & -- & -- & Calibration \\
\hline 9094 & 351215099292401 & 210 & -- & -- & -- & -- & Calibration \\
\hline 9095 & 351216099483501 & 86 & -- & -- & -- & -- & Calibration \\
\hline 9096 & 351222099395801 & -- & -- & -- & -- & -- & Calibration \\
\hline 9097 & 351242099420601 & 123 & -- & -- & -- & -- & Calibration \\
\hline 9098 & 351301099323301 & 74 & -- & -- & -- & -- & Calibration \\
\hline 9099 & 351306099515501 & 33 & -- & -- & -- & -- & Calibration \\
\hline 9100 & 351308099353601 & 148 & -- & -- & -- & -- & Calibration \\
\hline 9101 & 351327099595901 & 70 & -- & -- & -- & -- & Calibration \\
\hline 9102 & 351334099344001 & 67 & -- & -- & -- & -- & Calibration \\
\hline 9103 & 351347099324101 & 64 & -- & -- & -- & -- & Calibration \\
\hline 9104 & 351353099383101 & -- & -- & -- & -- & -- & Calibration \\
\hline 9105 & 351353099482701 & 100 & -- & -- & -- & -- & Calibration \\
\hline 9106 & 351400099533501 & 35 & -- & -- & -- & -- & Calibration \\
\hline 9107 & 351402099533501 & 36 & -- & -- & -- & -- & Calibration \\
\hline 9108 & 351413099451601 & 59 & -- & -- & -- & -- & Calibration \\
\hline 9109 & 351426099372701 & -- & -- & -- & -- & -- & Calibration \\
\hline 9110 & 351433099544101 & 217 & -- & -- & -- & -- & Calibration \\
\hline 9111 & 351446099362401 & 113 & -- & -- & -- & -- & Calibration \\
\hline 9112 & 351452099494701 & -- & -- & -- & -- & -- & Calibration \\
\hline 9113 & 351512099411001 & 30 & -- & -- & -- & -- & Calibration \\
\hline 9114 & 351512099472401 & 120 & -- & -- & -- & -- & Calibration \\
\hline 9115 & 351518099375901 & 130 & -- & -- & -- & -- & Calibration \\
\hline 9116 & 351525099560801 & 150 & -- & -- & -- & -- & Calibration \\
\hline 9117 & 351557099522601 & 160 & -- & -- & -- & -- & Calibration \\
\hline 9118 & 351617099482701 & 130 & -- & -- & -- & -- & Calibration \\
\hline 9119 & 351617099590301 & 63 & -- & -- & -- & -- & Calibration \\
\hline 9120 & 351637099521001 & -- & -- & -- & -- & -- & Calibration \\
\hline 9121 & 351755099563201 & -- & -- & -- & -- & -- & Calibration \\
\hline 9122 & 352328099560001 & 32 & -- & -- & -- & -- & Calibration \\
\hline 9123 & 352426099572801 & 90 & -- & -- & -- & -- & Calibration \\
\hline 9438 & 345356099212801 & 49 & -- & -- & -- & -- & Calibration \\
\hline 9439 & 345356099224001 & 50 & -- & -- & -- & -- & Calibration \\
\hline
\end{tabular}


Table 1. Selected data-collection stations in and near the North Fork Red River aquifer study area, southwest Oklahoma.-Continued [NAVD 88, North American Vertical Datum of 1988; >, greater than; SFR, Streamflow-Routing package; LAK, Lake package; WTF, water-table fluctuation method; SWB, Soil-Water Balance; m/d/y, month/day/year; --, not applicable or unknown]

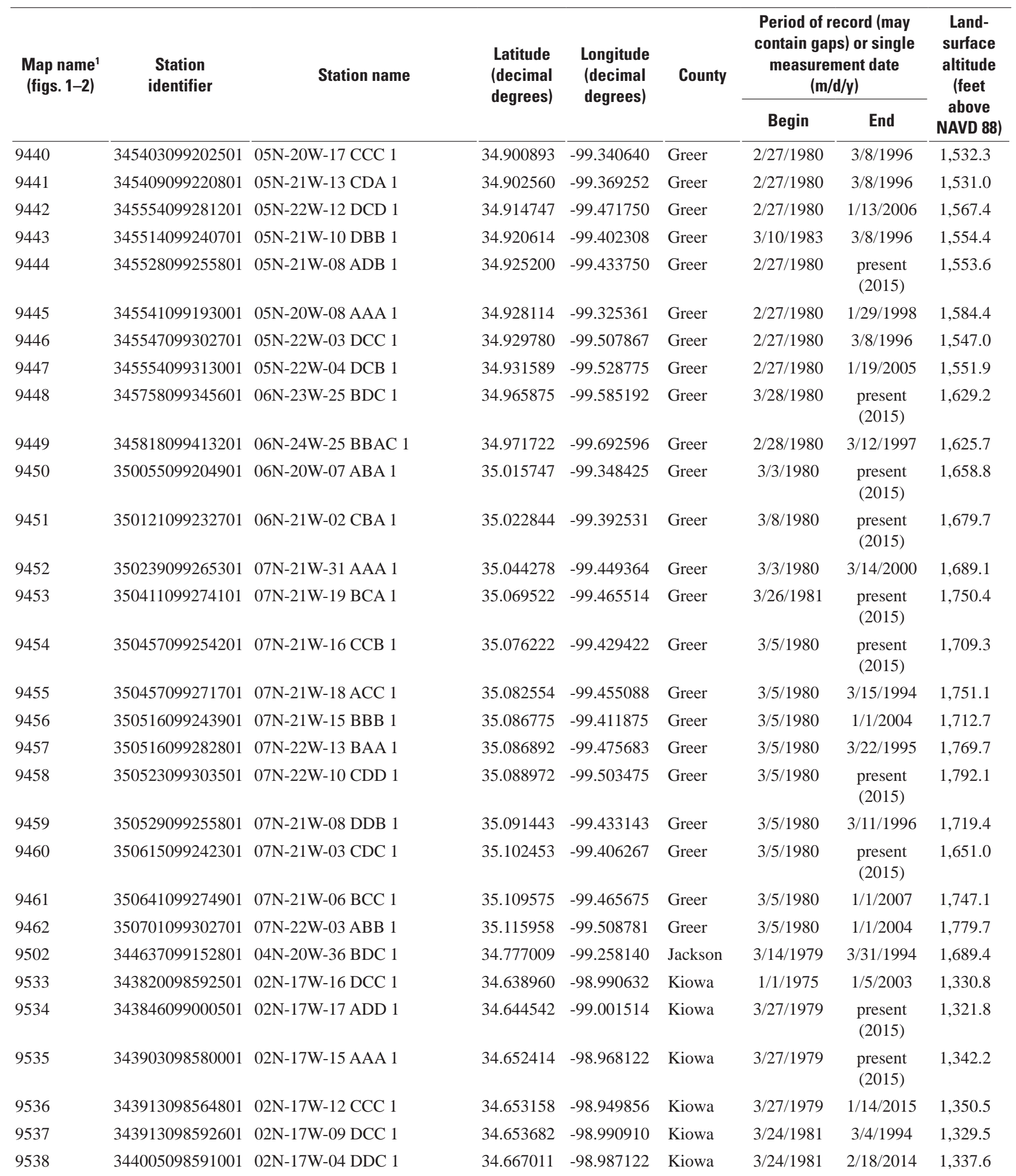




\begin{tabular}{|c|c|c|c|c|c|c|c|}
\hline \multirow{2}{*}{$\begin{array}{c}\text { Map name } \\
\text { (figs. 1-2) }\end{array}$} & \multirow{2}{*}{$\begin{array}{l}\text { Station } \\
\text { identifier }\end{array}$} & \multirow{2}{*}{$\begin{array}{c}\text { Well } \\
\text { or hole } \\
\text { depth } \\
\text { (feet) }\end{array}$} & \multicolumn{3}{|c|}{$\begin{array}{l}\text { Drainage area } \\
\text { (square miles) }\end{array}$} & \multirow{2}{*}{$\begin{array}{c}\text { Regulated ( }>20 \text { percent of } \\
\text { contributing drainage area } \\
\text { behind large dams) }\end{array}$} & \multirow{2}{*}{$\begin{array}{c}\text { Use in numerical } \\
\text { groundwater-flow } \\
\text { model }\end{array}$} \\
\hline & & & Total & $\begin{array}{l}\text { Contrib- } \\
\text { uting }\end{array}$ & $\begin{array}{l}\text { Noncon- } \\
\text { tributing }\end{array}$ & & \\
\hline 9440 & 345403099202501 & 58 & -- & -- & -- & -- & Calibration \\
\hline 9441 & 345409099220801 & 50 & -- & -- & -- & -- & Calibration \\
\hline 9442 & 345554099281201 & -- & -- & -- & -- & -- & Calibration \\
\hline 9443 & 345514099240701 & 66 & -- & -- & -- & -- & Calibration \\
\hline 9444 & 345528099255801 & 52 & -- & -- & -- & -- & Calibration \\
\hline 9445 & 345541099193001 & 57 & -- & -- & -- & -- & Calibration \\
\hline 9446 & 345547099302701 & 28 & -- & -- & -- & -- & Calibration \\
\hline 9447 & 345554099313001 & 24 & -- & -- & -- & -- & Calibration \\
\hline 9448 & 345758099345601 & 47 & -- & -- & -- & -- & Calibration \\
\hline 9449 & 345818099413201 & 24 & -- & -- & -- & -- & Calibration \\
\hline 9450 & 350055099204901 & 52 & -- & -- & -- & -- & Calibration \\
\hline 9451 & 350121099232701 & 75 & -- & -- & -- & -- & Calibration \\
\hline 9452 & 350239099265301 & 68 & -- & -- & -- & -- & Calibration \\
\hline 9453 & 350411099274101 & 67 & -- & -- & -- & -- & Calibration \\
\hline 9454 & 350457099254201 & 71 & -- & -- & -- & -- & Calibration \\
\hline 9455 & 350457099271701 & -- & -- & -- & -- & -- & Calibration \\
\hline 9456 & 350516099243901 & -- & -- & -- & -- & -- & Calibration \\
\hline 9457 & 350516099282801 & 82 & -- & -- & -- & -- & Calibration \\
\hline 9458 & 350523099303501 & 72 & -- & -- & -- & -- & Calibration \\
\hline 9459 & 350529099255801 & 70 & -- & -- & -- & -- & Calibration \\
\hline 9460 & 350615099242301 & 49 & -- & -- & -- & -- & Calibration \\
\hline 9461 & 350641099274901 & -- & -- & -- & -- & -- & Calibration \\
\hline 9462 & 350701099302701 & 113 & -- & -- & -- & -- & Calibration \\
\hline 9502 & 344637099152801 & -- & -- & -- & -- & -- & Calibration \\
\hline 9533 & 343820098592501 & 55 & -- & -- & -- & -- & Calibration \\
\hline 9534 & 343846099000501 & 40 & -- & -- & -- & -- & Calibration \\
\hline 9535 & 343903098580001 & 45 & -- & -- & -- & -- & Calibration \\
\hline 9536 & 343913098564801 & 48 & -- & -- & -- & -- & Calibration \\
\hline 9537 & 343913098592601 & 49 & -- & -- & -- & -- & Calibration \\
\hline 9538 & 344005098591001 & 44 & -- & -- & -- & -- & Calibration \\
\hline
\end{tabular}


Table 1. Selected data-collection stations in and near the North Fork Red River aquifer study area, southwest Oklahoma. - Continued [NAVD 88, North American Vertical Datum of 1988; >, greater than; SFR, Streamflow-Routing package; LAK, Lake package; WTF, water-table fluctuation method; SWB, Soil-Water Balance; m/d/y, month/day/year; --, not applicable or unknown]

\begin{tabular}{|c|c|c|c|c|c|c|c|c|}
\hline \multirow[t]{2}{*}{$\begin{array}{c}\text { Map name' } \\
\text { (figs. 1-2) }\end{array}$} & \multirow[t]{2}{*}{$\begin{array}{l}\text { Station } \\
\text { identifier }\end{array}$} & \multirow[t]{2}{*}{ Station name } & \multirow[t]{2}{*}{$\begin{array}{l}\text { Latitude } \\
\text { (decimal } \\
\text { degrees) }\end{array}$} & \multirow[t]{2}{*}{$\begin{array}{l}\text { Longitude } \\
\text { (decimal } \\
\text { degrees) }\end{array}$} & \multirow[t]{2}{*}{ County } & \multicolumn{2}{|c|}{$\begin{array}{l}\text { Period of record (may } \\
\text { contain gaps) or single } \\
\text { measurement date } \\
(\mathrm{m} / \mathrm{d} / \mathrm{y})\end{array}$} & \multirow{2}{*}{$\begin{array}{c}\text { Land- } \\
\text { surface } \\
\text { altitude } \\
\text { (feet } \\
\text { above } \\
\text { NAVD 88) }\end{array}$} \\
\hline & & & & & & Begin & End & \\
\hline 9539 & 344149098582301 & 03N-17W-27 DCC 1 & 34.696044 & -98.973492 & Kiowa & 3/27/1979 & $\begin{array}{l}\text { present } \\
\text { (2015) }\end{array}$ & $1,351.8$ \\
\hline 9540 & 344210098593501 & 03N-17W-28 CA 1 & 34.700344 & -98.992775 & Kiowa & $1 / 28 / 1976$ & $\begin{array}{l}\text { present } \\
\text { (2015) }\end{array}$ & $1,353.7$ \\
\hline 9542 & 344637099085401 & 04N-19W-36 ACC 1 & 34.777009 & -99.148692 & Kiowa & 3/24/1981 & 1/16/1996 & $1,398.3$ \\
\hline 9543 & 344745099083001 & 04N-19W-25 AAA 1 & 34.797353 & -99.141792 & Kiowa & 3/13/1979 & $\begin{array}{l}\text { present } \\
\text { (2015) }\end{array}$ & $1,408.9$ \\
\hline 9544 & 344821099082201 & 04N-18W-19 BCC 1 & 34.804831 & -99.141456 & Kiowa & 3/13/1979 & 3/22/1999 & $1,405.1$ \\
\hline 9545 & 345659099162001 & 06N-20W-35 DAA 1 & 34.950294 & -99.272633 & Kiowa & 1/1/1977 & $\begin{array}{l}\text { present } \\
\text { (2015) }\end{array}$ & $1,561.7$ \\
\hline 9546 & 345732099181801 & 06N-20W-27 CCC 1 & 34.958947 & -99.305360 & Kiowa & 1/1/1977 & 3/22/1995 & $1,578.9$ \\
\hline 9547 & 345751099185801 & 06N-20W-28 CAA 1 & 34.964224 & -99.316472 & Kiowa & 3/8/1979 & 3/11/1996 & $1,570.4$ \\
\hline 9548 & 345818099193001 & 06N-20W-29 AAA 1 & 34.971724 & -99.325361 & Kiowa & 3/27/1979 & $2 / 4 / 2003$ & $1,572.7$ \\
\hline 9549 & 345824099165901 & 06N-20W-23 CDC 1 & 34.972561 & -99.285403 & Kiowa & $1 / 1 / 1977$ & $\begin{array}{l}\text { present } \\
\text { (2015) }\end{array}$ & $1,591.1$ \\
\hline 9550 & 345824099185001 & 06N-20W-21 DCC 2 & 35.004878 & -99.315158 & Kiowa & 1/1/1977 & $3 / 25 / 2010$ & $1,587.5$ \\
\hline 9551 & 345831099191401 & 06N-20W-21 CCA 1 & 34.976347 & -99.320603 & Kiowa & $1 / 1 / 1977$ & $2 / 5 / 2003$ & $1,580.2$ \\
\hline 9552 & 345844099193001 & 06N-20W-20 DAA 1 & 34.978946 & -99.325361 & Kiowa & $1 / 1 / 1977$ & $2 / 4 / 2003$ & $1,577.6$ \\
\hline 9553 & 345857099193001 & 06N-20W-20 ADA 2 & 34.983828 & -99.325422 & Kiowa & 3/8/1977 & $\begin{array}{l}\text { present } \\
(2015)\end{array}$ & $1,582.4$ \\
\hline \multicolumn{9}{|c|}{ vey, 2015a); Land-surface elevations from U.S. Geological Survey (2015b) } \\
\hline- & 351125099414301 & 08N-24W-02 DDD 1 & 35.190330 & -99.695653 & Beckham & 3/3/1952 & $1 / 8 / 1985$ & $1,917.1$ \\
\hline-- & 350806099302701 & 08N-22W-27 DCB 1 & 35.135053 & -99.507868 & Beckham & \multicolumn{2}{|c|}{$4 / 8 / 1980$} & $1,732.2$ \\
\hline-- & 352525099543501 & 11N-26W-13 CCC 1 & 35.423661 & -99.910109 & $\begin{array}{l}\text { Roger } \\
\text { Mills }\end{array}$ & \multicolumn{2}{|c|}{$11 / 5 / 1980$} & $2,164.4$ \\
\hline-- & 351646099515801 & 09N-25W-05 D 1 & 35.279496 & -99.866493 & Beckham & \multicolumn{2}{|c|}{ 2/18/1981 } & $1,960.3$ \\
\hline -- & 352433099550501 & 11N-26W-23 DDB 1 & 35.409217 & -99.918442 & Beckham & \multicolumn{2}{|c|}{ 8/23/1981 } & $2,156.1$ \\
\hline-- & 350809099304701 & $08 \mathrm{~N}-22 \mathrm{~W}-27 \mathrm{C} 1$ & 35.135887 & -99.513424 & Beckham & \multicolumn{2}{|c|}{ 8/31/1981 } & $1,738.5$ \\
\hline-- & 351518099535301 & 09N-26W-13 ADD 1 & 35.255052 & -99.898438 & Beckham & \multicolumn{2}{|c|}{ 10/23/1981 } & $2,017.0$ \\
\hline -- & 345348099292601 & 05N-22W-23 ABCC 1 & 34.897281 & -99.493422 & Greer & 5/15/1986 & 10/13/1987 & $1,590.6$ \\
\hline-- & 343819099060001 & 02N-18W-16 CDC 1 & 34.638517 & -99.100017 & Kiowa & \multicolumn{2}{|c|}{ 9/10/2003 } & $1,312.9$ \\
\hline-- & 343851099055401 & 02N-18W-16 BDA 1 & 34.647383 & -99.098317 & Jackson & \multicolumn{2}{|c|}{ 9/10/2003 } & $1,314.4$ \\
\hline -- & 352035099570501 & 10N-26W-16 ACD 1 & 35.343125 & -99.951464 & Beckham & \multicolumn{2}{|c|}{$12 / 5 / 2012$} & $2,048.8$ \\
\hline-- & 352100099593201 & 10N-26W-07 CDD 1 & 35.350089 & -99.992344 & Beckham & \multicolumn{2}{|c|}{$12 / 5 / 2012$} & $2,102.4$ \\
\hline-- & 351438099513101 & 09N-25W-21 ВСВ 1 & 35.243983 & -99.858708 & Beckham & \multicolumn{2}{|c|}{ 12/6/2012 } & $2,034.2$ \\
\hline-- & 351453099502901 & 09N-25W-16 DDD 1 & 35.248236 & -99.841428 & Beckham & \multicolumn{2}{|c|}{$12 / 6 / 2012$} & $2,030.9$ \\
\hline-- & 351534099563201 & 09N-26W-15 BAC 1 & 35.259503 & -99.942417 & Beckham & \multicolumn{2}{|c|}{ 12/6/2012 } & $2,000.1$ \\
\hline-- & 351545099522001 & 09N-25W-08 CCD 1 & 35.262664 & -99.872258 & Beckham & \multicolumn{2}{|c|}{ 12/6/2012 } & $2,012.3$ \\
\hline-- & 351639099472301 & 09N-25W-01 DDD 1 & 35.277656 & -99.789989 & Beckham & \multicolumn{2}{|c|}{$12 / 6 / 2012$} & $1,946.1$ \\
\hline -- & 351232099424901 & 09N-24W-34 DAD 1 & 35.208953 & -99.713631 & Beckham & \multicolumn{2}{|c|}{ 12/7/2012 } & $1,932.1$ \\
\hline
\end{tabular}




\begin{tabular}{|c|c|c|c|c|c|c|c|}
\hline \multirow{2}{*}{$\begin{array}{c}\text { Map name } \\
\text { (figs. 1-2) }\end{array}$} & \multirow{2}{*}{$\begin{array}{c}\text { Station } \\
\text { identifier }\end{array}$} & \multirow{2}{*}{$\begin{array}{c}\text { Well } \\
\text { or hole } \\
\text { depth } \\
\text { (feet) }\end{array}$} & \multicolumn{3}{|c|}{$\begin{array}{l}\text { Drainage area } \\
\text { (square miles) }\end{array}$} & \multirow{2}{*}{$\begin{array}{l}\text { Regulated ( }>20 \text { percent of } \\
\text { contributing drainage area } \\
\text { behind large dams) }\end{array}$} & \multirow{2}{*}{$\begin{array}{c}\text { Use in numerical } \\
\text { groundwater-flow } \\
\text { model }\end{array}$} \\
\hline & & & Total & $\begin{array}{c}\text { Contrib- } \\
\text { uting }\end{array}$ & $\begin{array}{l}\text { Noncon- } \\
\text { tributing }\end{array}$ & & \\
\hline 9539 & 344149098582301 & 61 & -- & -- & -- & -- & Calibration \\
\hline 9540 & 344210098593501 & 40 & -- & -- & -- & -- & Calibration \\
\hline 9542 & 344637099085401 & -- & -- & -- & -- & -- & Calibration \\
\hline 9543 & 344745099083001 & 31 & -- & -- & -- & -- & Calibration \\
\hline 9544 & 344821099082201 & 23 & -- & -- & -- & -- & Calibration \\
\hline 9545 & 345659099162001 & -- & -- & -- & -- & -- & Calibration \\
\hline 9546 & 345732099181801 & 38 & -- & -- & -- & -- & Calibration \\
\hline 9547 & 345751099185801 & 57 & -- & -- & -- & -- & Calibration \\
\hline 9548 & 345818099193001 & 62 & -- & -- & -- & -- & Calibration \\
\hline 9549 & 345824099165901 & 38 & -- & -- & -- & -- & Calibration \\
\hline 9550 & 345824099185001 & 59 & -- & -- & -- & -- & Calibration \\
\hline 9551 & 345831099191401 & 66 & -- & -- & -- & -- & Calibration \\
\hline 9552 & 345844099193001 & 64 & -- & -- & -- & -- & Calibration \\
\hline 9553 & 345857099193001 & 68 & -- & -- & -- & -- & Calibration \\
\hline \multicolumn{8}{|c|}{ Water-table-altitude observation wells (U.S. Geological Survey, 2015a); Land-surface elevations from U.S. Geological Survey (2015b) } \\
\hline-- & 351125099414301 & 29 & -- & -- & -- & -- & Calibration \\
\hline-- & 350806099302701 & 30 & -- & -- & -- & -- & Calibration \\
\hline-- & 352525099543501 & 89.5 & -- & -- & -- & -- & Calibration \\
\hline-- & 351646099515801 & 40 & -- & -- & -- & -- & Calibration \\
\hline-- & 352433099550501 & 215 & -- & -- & -- & -- & Calibration \\
\hline-- & 350809099304701 & 56 & -- & -- & -- & -- & Calibration \\
\hline-- & 351518099535301 & 70 & -- & -- & -- & -- & Calibration \\
\hline-- & 345348099292601 & 50 & -- & -- & -- & -- & Calibration \\
\hline-- & 343819099060001 & 19.88 & -- & -- & -- & -- & Calibration \\
\hline-- & 343851099055401 & 17.5 & -- & -- & -- & -- & Calibration \\
\hline-- & 352035099570501 & -- & -- & -- & -- & -- & Calibration \\
\hline-- & 352100099593201 & 65 & -- & -- & -- & -- & Calibration \\
\hline-- & 351438099513101 & 220 & -- & -- & -- & -- & Calibration \\
\hline-- & 351453099502901 & 150 & -- & -- & -- & -- & Calibration \\
\hline-- & 351534099563201 & 150 & -- & -- & -- & -- & Calibration \\
\hline-- & 351545099522001 & 173 & -- & -- & -- & -- & Calibration \\
\hline-- & 351639099472301 & 100 & -- & -- & -- & -- & Calibration \\
\hline-- & 351232099424901 & 110 & -- & -- & -- & -- & Calibration \\
\hline
\end{tabular}


Table 1. Selected data-collection stations in and near the North Fork Red River aquifer study area, southwest Oklahoma.-Continued [NAVD 88, North American Vertical Datum of 1988; >, greater than; SFR, Streamflow-Routing package; LAK, Lake package; WTF, water-table fluctuation method; SWB, Soil-Water Balance; m/d/y, month/day/year; --, not applicable or unknown]

\begin{tabular}{|c|c|c|c|c|c|c|c|}
\hline \multirow[t]{2}{*}{$\begin{array}{l}\text { Map name' } \\
\text { (figs. 1-2) }\end{array}$} & \multirow[t]{2}{*}{$\begin{array}{c}\text { Station } \\
\text { identifier }\end{array}$} & \multirow[t]{2}{*}{ Station name } & \multirow[t]{2}{*}{$\begin{array}{l}\text { Latitude } \\
\text { (decimal } \\
\text { degrees) }\end{array}$} & \multirow[t]{2}{*}{$\begin{array}{l}\text { Longitude } \\
\text { (decimal } \\
\text { degrees) }\end{array}$} & \multirow[t]{2}{*}{ County } & $\begin{array}{c}\text { Period of record (may } \\
\text { contain gaps) or single } \\
\text { measurement date } \\
(\mathrm{m} / \mathrm{d} / \mathrm{y})\end{array}$ & \multirow{2}{*}{$\begin{array}{c}\text { Land- } \\
\text { surface } \\
\text { altitude } \\
\text { (feet } \\
\text { above } \\
\text { NAVD 88) }\end{array}$} \\
\hline & & & & & & Begin & \\
\hline-- & 351327099363701 & 09N-23W-26 CBB 1 & 35.224406 & -99.610497 & Beckham & $12 / 7 / 2012$ & $1,870.9$ \\
\hline-- & 350201099244001 & 07N-21W-34 CBC 1 & 35.033611 & -99.411139 & Greer & $12 / 11 / 2012$ & $1,650.9$ \\
\hline-- & 350244099281601 & 07N-22W-25 DCD 1 & 35.045678 & -99.471278 & Greer & $12 / 11 / 2012$ & $1,710.8$ \\
\hline-- & 350541099275501 & 07N-21W-07 BCC 1 & 35.094931 & -99.465492 & Greer & $12 / 11 / 2012$ & $1,759.3$ \\
\hline-- & 350701099302301 & 08N-22W-34 DCD 1 & 35.117100 & -99.506450 & Beckham & $12 / 11 / 2012$ & $1,781.3$ \\
\hline-- & 345737099343801 & 06N-23W-25 DCA 1 & 34.960497 & -99.577417 & Greer & $12 / 12 / 2012$ & $1,619.7$ \\
\hline-- & 351120099325101 & 08N-22W-08 BAB 1 & 35.189100 & -99.547739 & Beckham & $12 / 17 / 2012$ & $1,765.4$ \\
\hline-- & 351213099304801 & 08N-22W-03 ВАВ 1 & 35.203875 & -99.513478 & Beckham & $12 / 17 / 2012$ & $1,800.4$ \\
\hline-- & 351402099304001 & 09N-22W-22 DCD 1 & 35.234078 & -99.511275 & Beckham & $12 / 17 / 2012$ & $1,837.7$ \\
\hline-- & 350010099220001 & 06N-21W-12 DCD 1 & 35.002953 & -99.366808 & Greer & $12 / 18 / 2012$ & $1,678.0$ \\
\hline-- & 350029099212001 & 06N-20W-07 CAB 1 & 35.008317 & -99.355772 & Greer & $12 / 18 / 2012$ & $1,670.6$ \\
\hline-- & 350051099214001 & 06N-21W-12 AAA 1 & 35.014203 & -99.361208 & Greer & $12 / 18 / 2012$ & $1,662.7$ \\
\hline-- & 350214099213701 & 07N-21W-36 ADD 1 & 35.037356 & -99.360406 & Greer & $12 / 18 / 2012$ & $1,663.1$ \\
\hline-- & 350238099234401 & 07N-21W-27 DDD 1 & 35.044142 & -99.395794 & Greer & $12 / 18 / 2012$ & $1,628.5$ \\
\hline-- & 350412099234301 & 07N-21W-22 AAD 1 & 35.070189 & -99.395450 & Greer & $12 / 18 / 2012$ & $1,701.6$ \\
\hline-- & 350846099300701 & 08N-22W-22 DDD 1 & 35.146281 & -99.502092 & Beckham & $12 / 18 / 2012$ & $1,697.6$ \\
\hline-- & 350921099342001 & 08N-23W-24 ADA 1 & 35.155956 & -99.572406 & Beckham & $12 / 18 / 2012$ & $1,711.7$ \\
\hline-- & 345541099164901 & 05N-20W-11 ABB 1 & 34.928217 & -99.280411 & Kiowa & $12 / 19 / 2012$ & $1,571.6$ \\
\hline-- & 345729099182401 & 06N-20W-27 CCC 2 & 34.958097 & -99.306928 & Kiowa & 12/19/2012 & $1,577.4$ \\
\hline-- & 345811099193101 & 06N-20W-29 AAD 1 & 34.969992 & -99.325297 & Kiowa & $12 / 19 / 2012$ & $1,573.3$ \\
\hline-- & 350332099203301 & 07N-20W-20 CCC 1 & 35.058936 & -99.342739 & Kiowa & $12 / 19 / 2012$ & $1,622.5$ \\
\hline-- & 350337099210401 & 07N-20W-19 DCC 1 & 35.060294 & -99.351219 & Kiowa & $12 / 19 / 2012$ & $1,613.9$ \\
\hline-- & 350356099204801 & 07N-20W-19 DAB 1 & 35.065689 & -99.346842 & Kiowa & $12 / 19 / 2012$ & $1,620.7$ \\
\hline-- & 345451099155801 & 05N-20W-13 ВАВ 1 & 34.914267 & -99.266247 & Kiowa & $12 / 20 / 2012$ & $1,530.7$ \\
\hline-- & 344843099095701 & 04N-19W-14 DCD 1 & 34.812125 & -99.165892 & Jackson & 1/7/2013 & $1,437.5$ \\
\hline-- & 344845099121101 & 04N-19W-16 DCC 1 & 34.812525 & -99.203142 & Jackson & 1/7/2013 & $1,509.7$ \\
\hline-- & 345032099110801 & 04N-19W-03 CDD 1 & 34.842233 & -99.185778 & Jackson & 1/7/2013 & $1,471.5$ \\
\hline-- & 345054099111801 & 04N-19W-03 CAB 1 & 34.848569 & -99.188369 & Jackson & $1 / 7 / 2013$ & $1,430.7$ \\
\hline-- & 344220099154801 & 03N-20W-25 ВСВ 1 & 34.705689 & -99.263383 & Jackson & $1 / 8 / 2013$ & $1,411.5$ \\
\hline-- & 344327099172701 & 03N-20W-22 BAA 1 & 34.724206 & -99.291000 & Jackson & $1 / 8 / 2013$ & $1,453.3$ \\
\hline-- & 344636099180901 & 04N-20W-33 ADC 1 & 34.776669 & -99.302522 & Jackson & $1 / 8 / 2013$ & $1,530.4$ \\
\hline-- & 344650099144801 & 04N-20W-36 AAD 1 & 34.780661 & -99.246892 & Jackson & $1 / 8 / 2013$ & $1,650.4$ \\
\hline-- & 344838099173001 & 04N-20W-22 BAA 1 & 34.810808 & -99.291836 & Jackson & $1 / 8 / 2013$ & $1,556.8$ \\
\hline-- & 343840099011201 & 02N-17W-18 DAA 1 & 34.644536 & -99.020244 & Kiowa & 1/9/2013 & $1,369.9$ \\
\hline-- & 343910099041501 & 02N-18W-11 CCC 1 & 34.652836 & -99.070872 & Jackson & 1/9/2013 & $1,399.0$ \\
\hline-- & 344054099045301 & 03N-18W-34 CDD 1 & 34.681694 & -99.081556 & Jackson & $1 / 9 / 2013$ & $1,349.8$ \\
\hline-- & 344152099021001 & 03N-18W-25 DDA 1 & 34.697925 & -99.036108 & Kiowa & $1 / 9 / 2013$ & $1,359.7$ \\
\hline-- & 351806099442501 & 10N-24W-33 ACA 1 & 35.301775 & -99.740531 & Beckham & $1 / 10 / 2013$ & $1,936.5$ \\
\hline-- & 351932099430401 & 10N-24W-22 DAA 1 & 35.325736 & -99.717928 & Beckham & $1 / 10 / 2013$ & $2,010.2$ \\
\hline
\end{tabular}




\begin{tabular}{|c|c|c|c|c|c|c|c|}
\hline \multirow{2}{*}{$\begin{array}{c}\text { Map name' } \\
\text { (figs. 1-2) }\end{array}$} & \multirow{2}{*}{$\begin{array}{l}\text { Station } \\
\text { identifier }\end{array}$} & \multirow{2}{*}{$\begin{array}{c}\text { Well } \\
\text { or hole } \\
\text { depth } \\
\text { (feet) }\end{array}$} & \multicolumn{3}{|c|}{$\begin{array}{l}\text { Drainage area } \\
\text { (square miles) }\end{array}$} & \multirow{2}{*}{$\begin{array}{c}\text { Regulated ( }>20 \text { percent of } \\
\text { contributing drainage area } \\
\text { behind large dams) }\end{array}$} & \multirow{2}{*}{$\begin{array}{c}\text { Use in numerical } \\
\text { groundwater-flow } \\
\text { model }\end{array}$} \\
\hline & & & Total & $\begin{array}{l}\text { Contrib- } \\
\text { uting }\end{array}$ & $\begin{array}{l}\text { Noncon- } \\
\text { tributing }\end{array}$ & & \\
\hline- & 351327099363701 & 145 & -- & -- & -- & - & Calibration \\
\hline-- & 350201099244001 & 40 & -- & -- & -- & -- & Calibration \\
\hline-- & 350244099281601 & 47 & -- & -- & -- & -- & Calibration \\
\hline-- & 350541099275501 & 72 & -- & -- & -- & -- & Calibration \\
\hline-- & 350701099302301 & 127 & -- & -- & -- & -- & Calibration \\
\hline-- & 345737099343801 & 60 & -- & -- & -- & -- & Calibration \\
\hline-- & 351120099325101 & 50 & -- & -- & -- & -- & Calibration \\
\hline-- & 351213099304801 & 56 & -- & -- & -- & -- & Calibration \\
\hline-- & 351402099304001 & 65 & -- & -- & -- & -- & Calibration \\
\hline-- & 350010099220001 & 67 & -- & -- & -- & -- & Calibration \\
\hline-- & 350029099212001 & 81 & -- & -- & -- & -- & Calibration \\
\hline-- & 350051099214001 & 67 & -- & -- & -- & -- & Calibration \\
\hline-- & 350214099213701 & 39 & -- & -- & -- & -- & Calibration \\
\hline-- & 350238099234401 & 30 & -- & -- & -- & -- & Calibration \\
\hline-- & 350412099234301 & 57 & -- & -- & -- & -- & Calibration \\
\hline-- & 350846099300701 & 50 & -- & -- & -- & -- & Calibration \\
\hline-- & 350921099342001 & 40 & -- & -- & -- & -- & Calibration \\
\hline-- & 345541099164901 & 53.5 & -- & -- & -- & -- & Calibration \\
\hline-- & 345729099182401 & 39.4 & -- & -- & -- & -- & Calibration \\
\hline-- & 345811099193101 & -- & -- & -- & -- & -- & Calibration \\
\hline-- & 350332099203301 & 65 & -- & -- & -- & -- & Calibration \\
\hline-- & 350337099210401 & 33 & -- & -- & -- & -- & Calibration \\
\hline-- & 350356099204801 & 16.5 & -- & -- & -- & -- & Calibration \\
\hline-- & 345451099155801 & 29.5 & -- & -- & -- & -- & Calibration \\
\hline-- & 344843099095701 & 30 & -- & -- & -- & -- & Calibration \\
\hline-- & 344845099121101 & 54.28 & -- & -- & -- & -- & Calibration \\
\hline-- & 345032099110801 & 33.5 & -- & -- & -- & -- & Calibration \\
\hline-- & 345054099111801 & 25 & -- & -- & -- & -- & Calibration \\
\hline-- & 344220099154801 & 43.2 & -- & -- & -- & -- & Calibration \\
\hline-- & 344327099172701 & 44.5 & -- & -- & -- & -- & Calibration \\
\hline-- & 344636099180901 & -- & -- & -- & -- & -- & Calibration \\
\hline-- & 344650099144801 & 40 & -- & -- & -- & -- & Calibration \\
\hline-- & 344838099173001 & 72 & -- & -- & -- & -- & Calibration \\
\hline-- & 343840099011201 & 22.9 & -- & -- & -- & -- & Calibration \\
\hline-- & 343910099041501 & 32.6 & -- & -- & -- & -- & Calibration \\
\hline-- & 344054099045301 & 21 & -- & -- & -- & -- & Calibration \\
\hline-- & 344152099021001 & 15.9 & -- & -- & -- & -- & Calibration \\
\hline-- & 351806099442501 & -- & -- & -- & -- & -- & Calibration \\
\hline-- & 351932099430401 & 37.1 & -- & -- & -- & -- & Calibration \\
\hline
\end{tabular}


Table 1. Selected data-collection stations in and near the North Fork Red River aquifer study area, southwest Oklahoma.-Continued [NAVD 88, North American Vertical Datum of 1988; >, greater than; SFR, Streamflow-Routing package; LAK, Lake package; WTF, water-table fluctuation method; SWB, Soil-Water Balance; m/d/y, month/day/year; --, not applicable or unknown]

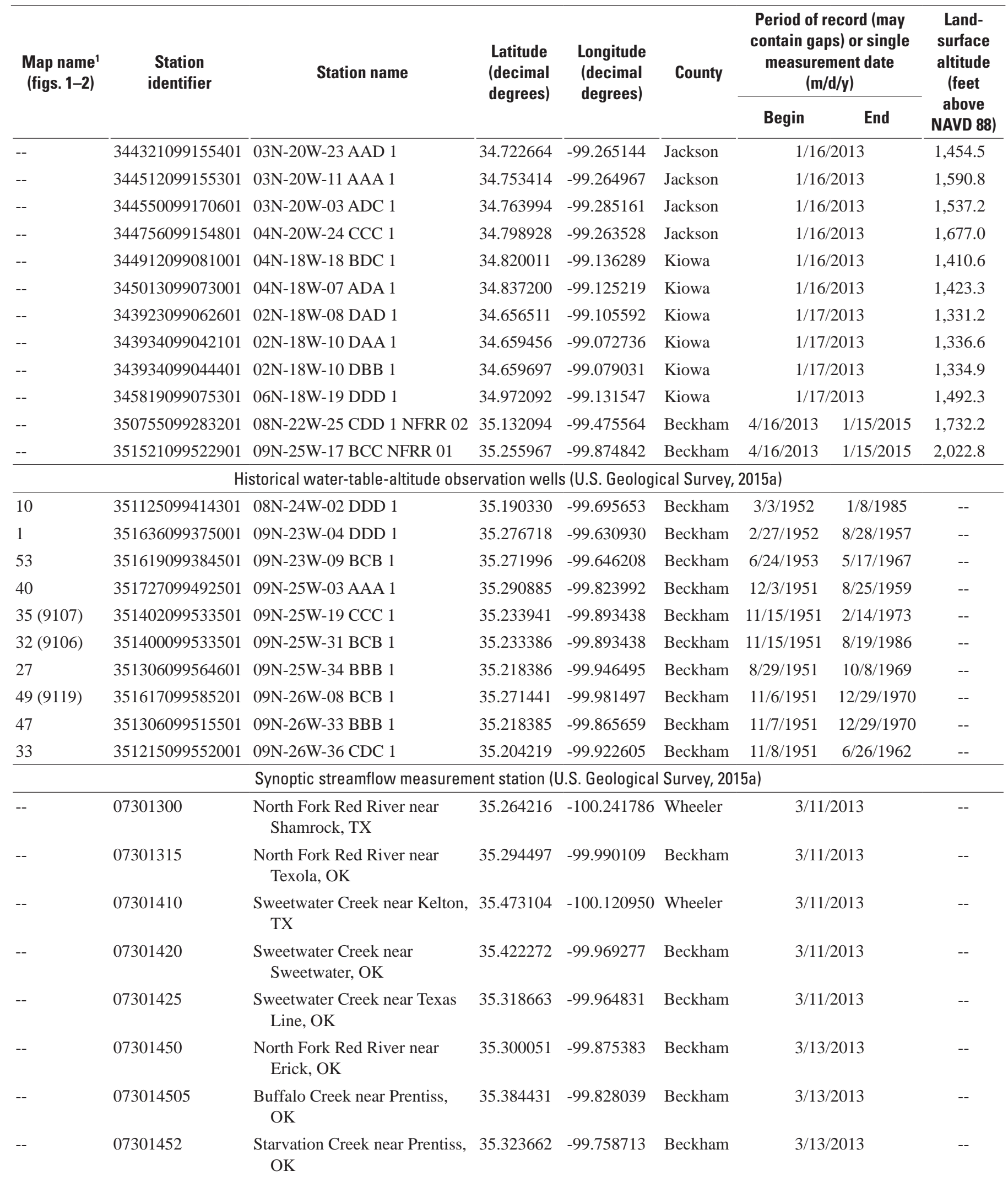




\begin{tabular}{|c|c|c|c|c|c|c|c|}
\hline \multirow{2}{*}{$\begin{array}{c}\text { Map name' } \\
\text { (figs. 1-2) }\end{array}$} & \multirow{2}{*}{$\begin{array}{l}\text { Station } \\
\text { identifier }\end{array}$} & \multirow{2}{*}{$\begin{array}{c}\text { Well } \\
\text { or hole } \\
\text { depth } \\
\text { (feet) }\end{array}$} & \multicolumn{3}{|c|}{$\begin{array}{l}\text { Drainage area } \\
\text { (square miles) }\end{array}$} & \multirow{2}{*}{$\begin{array}{c}\text { Regulated (>20 percent of } \\
\text { contributing drainage area } \\
\text { behind large dams) }\end{array}$} & \multirow{2}{*}{$\begin{array}{c}\text { Use in numerical } \\
\text { groundwater-flow } \\
\text { model }\end{array}$} \\
\hline & & & Total & $\begin{array}{l}\text { Contrib- } \\
\text { uting }\end{array}$ & $\begin{array}{l}\text { Noncon- } \\
\text { tributing }\end{array}$ & & \\
\hline- & 344321099155401 & 73 & -- & -- & -- & -- & Calibration \\
\hline-- & 344512099155301 & 73.75 & -- & -- & -- & -- & Calibration \\
\hline-- & 344550099170601 & 48.4 & -- & -- & -- & -- & Calibration \\
\hline-- & 344756099154801 & 76 & -- & -- & -- & -- & Calibration \\
\hline-- & 344912099081001 & 22 & -- & -- & -- & -- & Calibration \\
\hline-- & 345013099073001 & 34.2 & -- & -- & -- & -- & Calibration \\
\hline-- & 343923099062601 & 24 & -- & -- & -- & -- & Calibration \\
\hline-- & 343934099042101 & 21 & -- & -- & -- & -- & Calibration \\
\hline-- & 343934099044401 & 20.2 & -- & -- & -- & -- & Calibration \\
\hline-- & 345819099075301 & 20.5 & -- & -- & -- & -- & Calibration \\
\hline-- & 350755099283201 & 75.4 & -- & -- & -- & -- & Calibration \\
\hline-- & 351521099522901 & 117 & -- & -- & -- & -- & Calibration \\
\hline \multicolumn{8}{|c|}{ Historical water-table-altitude observation wells (U.S. Geological Survey, 2015a) } \\
\hline 10 & 351125099414301 & 29 & -- & -- & -- & -- & -- \\
\hline 1 & 351636099375001 & 33.4 & -- & -- & -- & -- & -- \\
\hline 53 & 351619099384501 & 23.7 & -- & -- & -- & -- & -- \\
\hline 40 & 351727099492501 & 40 & -- & -- & -- & -- & -- \\
\hline 35 (9107) & 351402099533501 & 36 & -- & -- & -- & -- & -- \\
\hline 32 (9106) & 351400099533501 & 34.8 & -- & -- & -- & -- & -- \\
\hline 27 & 351306099564601 & 78.6 & -- & -- & -- & -- & -- \\
\hline 49 (9119) & 351617099585201 & 62.7 & -- & -- & -- & -- & -- \\
\hline 47 & 351306099515501 & 32.8 & -- & -- & -- & -- & -- \\
\hline 33 & 351215099552001 & 26.9 & -- & -- & -- & -- & -- \\
\hline \multicolumn{8}{|c|}{ Synoptic streamflow measurement station (U.S. Geological Survey, 2015a) } \\
\hline-- & 07301300 & -- & -- & -- & -- & -- & Streambed seepage \\
\hline-- & 07301315 & -- & -- & -- & -- & -- & Streambed seepage \\
\hline-- & 07301410 & -- & -- & -- & -- & -- & Streambed seepage \\
\hline-- & 07301420 & -- & -- & -- & -- & -- & Streambed seepage \\
\hline-- & 07301425 & -- & -- & -- & -- & -- & Streambed seepage \\
\hline-- & 07301450 & -- & -- & -- & -- & -- & Streambed seepage \\
\hline-- & 073014505 & -- & -- & -- & -- & -- & Streambed seepage \\
\hline-- & 07301452 & -- & -- & -- & -- & -- & Streambed seepage \\
\hline
\end{tabular}


Table 1. Selected data-collection stations in and near the North Fork Red River aquifer study area, southwest Oklahoma.-Continued

[NAVD 88, North American Vertical Datum of 1988; >, greater than; SFR, Streamflow-Routing package; LAK, Lake package; WTF, water-table fluctuation method; SWB, Soil-Water Balance; m/d/y, month/day/year; --, not applicable or unknown]

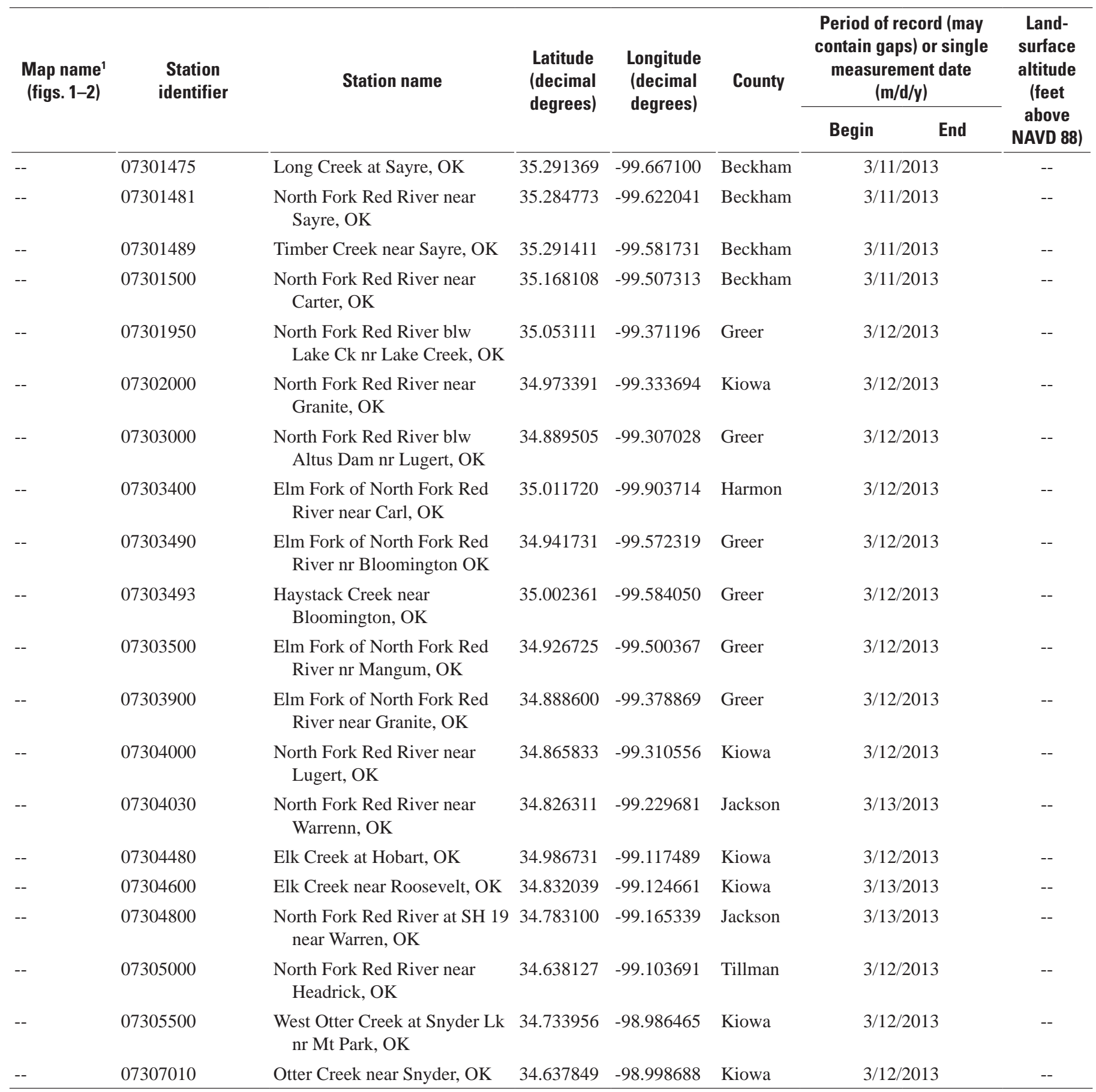

${ }^{1}$ Only sites discussed in this report are labeled on figures 1 and 2. 


\begin{tabular}{|c|c|c|c|c|c|c|c|}
\hline $\begin{array}{c}\text { Map name } \\
\text { (figs. 1-2) }\end{array}$ & $\begin{array}{l}\text { Station } \\
\text { identifier }\end{array}$ & $\begin{array}{c}\text { Well } \\
\text { or hole } \\
\text { depth } \\
\text { (feet) }\end{array}$ & \multicolumn{3}{|c|}{$\begin{array}{l}\text { Drainage area } \\
\text { (square miles) }\end{array}$} & $\begin{array}{c}\text { Regulated ( }>20 \text { percent of } \\
\text { contributing drainage area } \\
\text { behind large dams) }\end{array}$ & $\begin{array}{c}\text { Use in numerical } \\
\text { groundwater-flow } \\
\text { model }\end{array}$ \\
\hline-- & 07301475 & -- & -- & -- & -- & -- & Streambed seepage \\
\hline -- & 07301489 & -- & -- & -- & -- & -- & Streambed seepage \\
\hline-- & 07301500 & -- & -- & -- & -- & -- & Streambed seepage \\
\hline-- & 07301950 & -- & -- & -- & -- & -- & Streambed seepage \\
\hline -- & 07303400 & -- & -- & -- & -- & -- & Streambed seepage \\
\hline-- & 07303490 & -- & -- & -- & -- & -- & Streambed seepage \\
\hline-- & 07303493 & -- & -- & -- & -- & -- & Streambed seepage \\
\hline-- & 07303500 & -- & -- & -- & -- & -- & Streambed seepage \\
\hline-- & 07303900 & -- & -- & -- & -- & -- & Streambed seepage \\
\hline-- & 07304600 & -- & -- & -- & -- & -- & Streambed seepage \\
\hline -- & 07304800 & -- & -- & -- & -- & -- & Streambed seepage \\
\hline-- & 07305000 & -- & -- & -- & -- & -- & Streambed seepage \\
\hline-- & 07305500 & -- & -- & -- & -- & -- & Streambed seepage \\
\hline-- & 07307010 & -- & -- & -- & -- & -- & Streambed seepage \\
\hline
\end{tabular}


For more information about this publication, contact

Director, Oklahoma Water Science Center

U.S. Geological Survey

202 NW 66th

Oklahoma City, OK 73116

For additional information visit

https://www.usgs.gov/centers/ok-water/

Publishing support provided by

Lafayette Publishing Service Center 

